\title{
Modeling Of Hydrologic Conditions And Solute Movement In Processed Oil Shale Waste Embankments Under Simulated Climatic Conditions
}

\section{Final Report \\ November 1995}

Work Performed Under Contract No.: DE-FC21-86LC11084

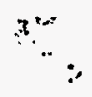

For

U.S. Department of Energy

Office of Fossil Energy

Morgantown Energy Technology Center

Morgantown, West Virginia

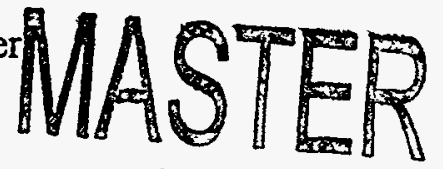

By

University of Wyoming

Department of Rangeland Ecology and Watershed Management

Laramie, Wyoming 82071 


\section{DISCLAIMER}

This report was prepared as an account of work sponsored by an agency of the United States Government. Neither the United States Government nor any agency thereof, nor any of their employees, makes any warranty, express or implied, or assumes any legal liability or responsibility for the accuracy, completeness, or usefulness of any information, apparatus, product, or process disclosed, or represents that its use would not infringe privately owned rights. Reference herein to any specific commercial product, process, or service by trade name, trademark, manufacturer, or otherwise does not necessarily constitute or imply its endorsement, recommendation, or favoring by the United States Government or any agency thereof. The views and opinions of authors expressed herein do not necessarily state or reflect those of the United States Government or any agency thereof.

Available to the public from the National Technical Information Service, U.S. Department of Commerce, 5285 Port Royal Road, Springfield, VA 22161; phone orders accepted at (703) 487-4650.

This report has been reproduced directly from the best available copy. 


\section{DISCLAIMER}

Portions of this document may be illegible in electronic image products. Images are produced from the best available original document. 


\title{
Modeling Of Hydrologic Conditions And Solute Movement In Processed Oil Shale Waste Embankments Under Simulated Climatic Conditions
}

\author{
Final Report \\ November 1995
}

Work Performed Under Contract No.: DE-FC21-86MC11084

\author{
For \\ U.S. Department of Energy \\ Office of Fossil Energy \\ Morgantown Energy Technology Center \\ P.O. Box 880 \\ Morgantown, West Virginia 26507-0880 \\ By \\ University of Wyoming \\ Department of Rangeland Ecology and Watershed Management \\ Laramie, Wyoming 82071
}




\section{ABSTRACT}

A study is described on the hydrological and geotechnical behavior of an oil shale solid waste. The objective was to obtain information which can be used by the U.S. Department of Energy, other government regulatory agencies, and private industries involved in oil shale development to assess the environmental impacts of oil shale solid waste disposal in the Green River Basin.

The spent shale used in this study was combusted by the Lurgi-Ruhrgas process by Rio Blanco Oil Shale Company, Inc. Laboratory bench-scale testing included index properties, such as grain size distribution and Atterberg limits, and tests for engineering properties including hydraulic conductivity and shear strength. Large-scale tests were conducted on model spent shale waste embankments to evaluate hydrological response, including infiltration, runoff, and seepage. Large-scale tests were conducted at a field site in western Colorado and in the Environmental Simulation Laboratory (ESL) at the University of Wyoming. The ESL tests allowed the investigators to control rainfall and temperature, providing information on the hydrological response of spent shale under simulated severe climatic conditions. All experimental methods, materials, facilities, and instrumentation are described in detail.

Results of bench-scale laboratory tests show that the Lurgi spent shale consists primarily of sand and silt size particles. Most of the material was classified as silty sand (SM) in the Unified Soil Classification System. Test results demonstrated that cementation of Lurgi spent shale, which occurs when the spent shale is mixed with water, is the single most significant factor affecting its engineering properties. When bench-scale specimens are mixed with water, compacted, and allowed to cure, the unconfined compressive strength increases and hydraulic conductivity decreases with increasing initial water content. Mixing with water and compaction of large quantities of spent shale, as was done for the large-scale tests of this study, resulted in significantly different properties than those of bench-scale specimens. These differences are attributed to differences in soil texture. Spent shale for the large-scale tests was mixed to a water content of approximately ten percent using standard concrete mixing equipment, placed in lifts, and compacted. This procedure resulted in zones in which the spent shale formed large (up to $1 \mathrm{~cm}$ in diameter) aggregations, giving the texture of a coarse sand or gravel, and resulting in significantly higher hydraulic conductivities and lower unconfined compressive strengths than bench-scale specimens, which consisted of dense, uniformly cemented materials with low porosity. Implications for the effects of cementation on testing procedures used to evaluate field-scale performance are discussed. 
Large-scale tests on model embankments were used to measure the complete hydrological response of Lurgi spent shale under field and simulated climatic conditions. These data can be used to evaluate a complete water budget, including the generation of leachate, for full-scale waste embankments. A review of currently available computer codes for evaluation of hydrologic response and solute transport is presented. An initial attempt to model the response of a model embankment to twenty three rain storm events in the ESL was made using the program UNSAT2. Results showed that the program was a reasonably good predictor of runoff and infiltration for the first ten rainfall events, but a poor predictor once the embankment became saturated and started to drain from the bottom. The performance is attributed in part to the difficulties in assessing the in situ engineering properties of the spent shale, especially its hydraulic conductivity under partially saturated conditions. Further research is recommended to identify computer codes and methods to evaluate the required input properties for application to full-scale waste embankments. 


\section{ACKNOWLEDGMENTS}

This research program was initiated in 1986 under a Cooperative Agreement between the U.S. Department of Energy, Laramie Projects Office and the University of Wyoming (UW), Contract Number DE-FC21-86LC11084. Cooperative agreements were also established between the University of Wyoming and Rio Blanco Oil Shale Co., Inc. (RBOSC) in 1987 and between the University of Wyoming and Exxon USA, Colony Shale Oil Project, in 1988. Many significant contributions to this study were made by the DOE-LPO Technical Project Officer, Mr. Richard McQuisten. Mr. McQuisten's conceptual and dedicated insight into the value of large-scale test bed experimentation, in which climatic factors and the hydrologic cycle are controlled, contributed significantly to the success of this study. Individuals from the oil shale industry, especially Earl York, Vern Butler, and Howard Earnst of RBOSC, provided valuable support to this study. Daily supervision of research programming was carried out by UW Research Associates Tim Reeves, Ron Siekert, and Douglas Smith. Graduate students who participated in this study included Robert Rothwell, Srinivasan Rangarajan, Beth Heesen, and Jeff Knapton. The principal investigators extend their sincere appreciation to all of the above for their dedication and service to oil shale solid waste research. 


\section{TABLE OF CONTENTS}

SECTION

Page

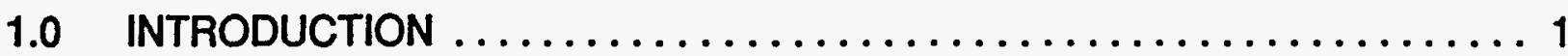

1.1 Background and Statement of the Problem $\ldots \ldots \ldots \ldots \ldots \ldots \ldots$

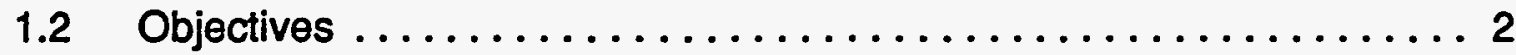

1.3 Scope of Study $\ldots \ldots \ldots \ldots \ldots \ldots \ldots \ldots \ldots \ldots \ldots \ldots \ldots$

2.0 REVIEW OF PREVIOUS WORK . . . . . . . . . . . . . . . . 7

2.1 Overview of Spent Shale Processing Methods .............. . 7

2.2 Disposal of Spent Shale ...................... 7

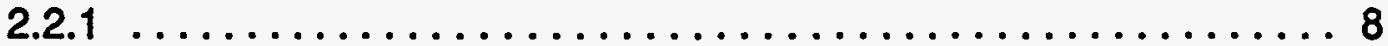

2.3 Review of Spent Shale Physical and Engineering Properties . . . . . . . 9

2.3.1 Gradation and Index Properties ................. 9

2.3.2 Compaction Characteristics ................... 10

2.3.4 Shear Strength . . . . . . . . . . . . . . . . . 10

2.3.5 Hydraulic Conductivity ................... 11

2.4 Modeling Studies $\ldots \ldots \ldots \ldots \ldots \ldots \ldots \ldots \ldots \ldots \ldots \ldots$

2.4.1 Analysis of a Hypothetical Spent Shale Disposal System . . . . 17

2.4.2 Simulation of Water and Solute Movement ............ 20

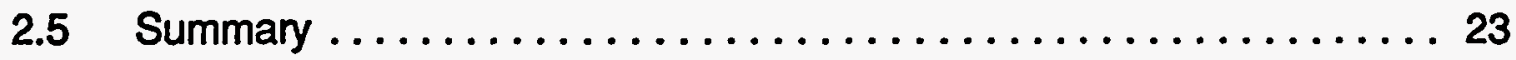

3.0 BENCH-SCALE CHARACTERIZATION OF GEOTECHNICAL

PROPERTIES

3.1 Materials ............................. 24

3.2 Geotechnical Properties - Methods . . . . . . . . . . . . . . . 24

3.3 Geotechnical Properties - Results ................... 30

3.3 .1 Index Properties . . . . . . . . . . . . . . . . 30

3.3.2 Moisture-Density Relationships ................ 34

3.3.3 Shear Strength . . . . . . . . . . . . . . . . . 34

3.3.4 Hydraulic Conductivity .................... 39

3.3.5 Effects of Weathering . . . . . . . . . . . . . . 45 


\section{TABLE OF CONTENTS}

3.3.6 Soil Moisture Characteristic Curves .............. 51

3.3.7 Discussion on the Effects of Cementation on Geotechnical Properties ............................ 54

3.4 Leachate Chemistry ......................... 56

3.4.1 Methods ........................... 56

3.4.2 Results of Leachate Chemistry Analysis ........... 57

4.0 HYDROLOGIC RESPONSE TO SIMULATED CLIMATIC CONDITIONS ... 64

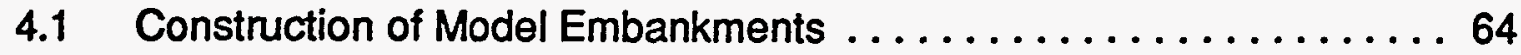

4.1.1 The Environmental Simulation Laboratory ........... 64

4.1.2 Test Embankments . . . . . . . . . . . . . . . . . 66

4.2 In Situ Instrumentation . . . . . . . . . . . . . . . . 69

4.2.1 Neutron Moderation ..................... 69

4.2.2 Time Domain Reflectometry (TDR) $\ldots \ldots \ldots \ldots \ldots \ldots \ldots 70$

4.2.3 Temperature Measurements ................. 74

4.2 .4 In Situ State of Stress . . . . . . . . . . . . . . . . 74

4.3 In Situ Testing Methods ....................... 74

4.3.1 Infiltration and Vertical Hydraulic Conductivity ......... 74

4.3.2 Horizontal Hydraulic Conductivity $\ldots \ldots \ldots \ldots \ldots \ldots \ldots .77$

4.4 Back Calculation Technique ...................... 79

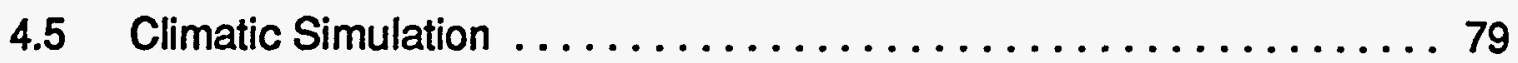

4.5.1 RBOSC Field Site . . . . . . . . . . . . . . . . 79

4.5.2 Climatic History of ESL Test Embankments . . . . . . . . . 81

4.6 Results of In Situ Hydraulic Conductivity Tests ............ 83

4.6.1 Vertical Hydraulic Conductivity ................. 83

4.6.2 Horizontal Hydraulic Conductivity $\ldots \ldots \ldots \ldots \ldots \ldots \ldots . \ldots . \ldots$

4.6.3 Discussion of In Situ Hydraulic Conductivity .......... 89

4.6.4 Changes in Grain Size Distribution .............. 91

4.6.5 In Situ Spatial and Temporal Variations ............. 93 


\section{TABLE OF CONTENTS}

4.7 Hydraulic Conductivity from Back Calculation Method ........... 94

4.8 Sampling and Testing Following Climatic Simulation .......... 104

4.8.1 RBOSC Field Lysimeters . . . . . . . . . . . . . . . . . . . 104

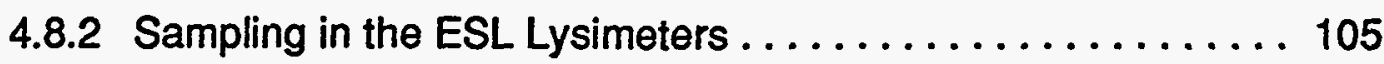

4.9 Summary ................................. 110

5.0 NUMERICAL MODELING OF HYDROLOGIC RESPONSE $\ldots \ldots \ldots \ldots \ldots 112$

5.1 Evaluation of Hydrogechemical Methods for Analysis of Oil Shale Solid Waste Embankments ....................... 112

5.1.1 Computer Code Selection .................. 113

5.1.2 One-Dimensional Hydrological Codes . ............ 114

5.1.3 Two-Dimensional Hydrological Codes . . ........... 115

5.1.4 Geochemical Codes ....................... 117

5.1.5 Comparison of One-Dimensional Unsaturated Flow Codes . . 119

5.1.6 Comparison of Two-Dimensional Codes ........... 120

5.1.7 Summary of Computer Code Capabilities ........... 123

5.2 Numerical Simulation of Infiltration and Flow $\ldots \ldots \ldots \ldots \ldots \ldots 129$

5.2.1 Overview of the Program UNSAT2 . . . . . . . . . . 129

5.2.2 Computer Simulation ................... 131

5.2.3 Discussion .......................... 135

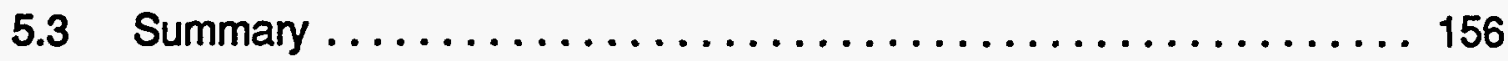

6.0 SUMMARY, CONCLUSIONS, AND RECOMMENDATIONS . ........ 157

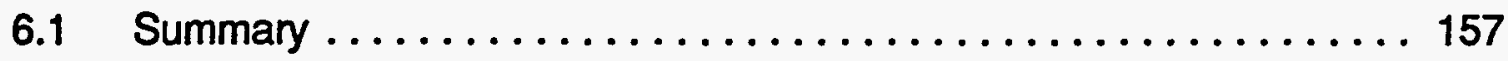

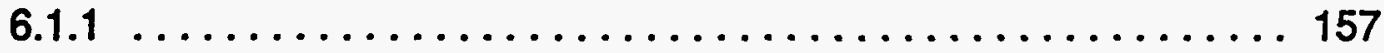

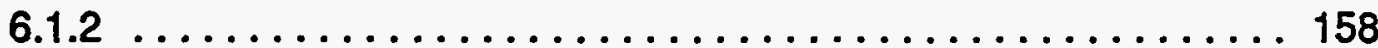

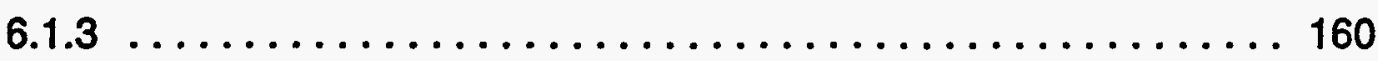

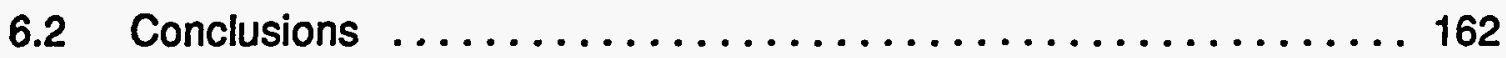

6.3 Recommendations $\ldots \ldots \ldots \ldots \ldots \ldots \ldots \ldots \ldots \ldots \ldots \ldots \ldots$

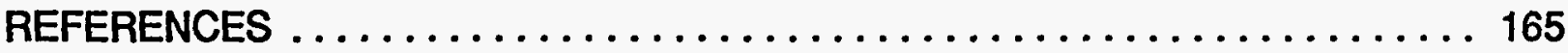

- vi - 


\subsection{INTRODUCTION}

\subsection{Background and Statement of the Problem}

Oil shale is a potential resource for liquid fuel needs in the United States. Western oil shale deposits in the Green River Formation of Colorado, Utah, and Wyoming are among the richest and most extensive in the world. The recoverable quantity of synthetic petroleum in the Green River Formation has been estimated at 1.8 trillion barrels (Prien 1980).

A significant technical problem associated with oil shale processing is disposal of the resulting solid wastes (referred to herein as spent shale) in a manner that is economical and environmentally safe. Most of the spent shale would likely be disposed of in engineered embankments. To illustrate the problem, consider a commercial industry processing $159,000 \mathrm{~m}^{3} / \mathrm{d}$ of oil shale (approximately 1 million barrels per day of shale oil). Such an operation would produce 250-300 million $\mathrm{m}^{3} /$ day of compacted spent shale (Bates and Thoem 1980). At this rate of production for thirty years, spent shale disposal piles could become the largest man-made structures ever built, potentially reaching heights of 300 to $500 \mathrm{~m}$ (Reeves, et al. 1986).

The performance requirements of oil shale solid waste disposal facilities are that they must: (1) be physically stable, (2) prevent or minimize the release of potentially harmful leachates into ground- and surface waters, and (3) minimize negative impacts on surface water flow patterns. Engineering design of disposal embankments therefore requires analysis of embankment stability, water infiltration and seepage, contaminant transport, surface water and groundwater hydrology, water quality, and cost estimates for construction of disposal embankments. These analyses require as input representative properties of the spent shale, including shear strength, hydraulic conductivity, contaminant transport coefficients, moisture-density relationships, and chemical composition. Water is a key factor that influences the properties of spent shale as well as the potential environmental impacts of spent shale disposal, and its interaction with spent shale is a key focus of this report. 


\subsection{Objectives}

This study was conducted to characterize the behavior of an oil shale solid waste under conditions representative of a disposal environment. The principal objective is to provide realistic information that can be used to evaluate potential environmental impacts of full-scale spent shale disposal facilities in the western United States. Such information is needed by agencies such as the U.S. Department of Energy, state environmental agencies in Colorado, Utah, and Wyoming, and by private companies involved in commercialization of oil shale production. The objectives of this research are to evaluate the following characteristics of spent shale disposal facilities:

- infiltration and movement of water and the potential for development of saturated zones and drainage, under natural and simulated climatic conditions;

- the applicability of available computer model(s) to quantify the infiltration, seepage, and drainage of water.

- movement of solubles and major chemical constituents under natural and simulated climatic conditions; and

- the physical and constitutive properties of the oil shale solid waste and potential changes in these properties caused by disposal and weathering by natural and simulated climatic conditions.

Table 1.1 at the end of this section outlines the detailed sub-objectives (tasks) associated with the main objectives stated above. 


\subsection{Scope of Study}

To achieve the objectives, the research program included bench-scale testing of spent shale specimens, construction and monitoring of field lysimeters, construction and testing of spent shale in indoor lysimeters, and numerical modeling of infiltration and seepage. Bench-scale testing was conducted to characterize the physical, chemical, and engineering properties of the spent shale, including leachate chemistry, mechanical and constitutive properties such as grain size distribution, Atterberg limits, moisture density relationships, shear strength, and saturated and unsaturated hydraulic conductivity. Large-scale testing of spent shale placed and compacted in lysimeters was used to study the hydrological response at a scale sufficient to model the behavior of commercialscale embankments. The large-scale testing was conducted in five lysimeters, each $7.3 \times 3.0 \times 3.0$ $\mathrm{m}$ deep, filled with spent shale which had been retorted and combusted by the Lurgi-Ruhrgas (Lurgi) process (Schmalfield 1975). Approximately 400 tons of Lurgi processed oil shale waste was provided by RBOSC to carry out this study.

Three of the lysimeters were established at the RBOSC Tract C-a in the Piceance Basin near Rifle, Colorado. The other two lysimeters are located in the Environmental Simulation Laboratory (ESL) at UW. The ESL was specifically designed and constructed so that a large range of climatic conditions could be applied to the spent shale which was placed in the lysimeter cells. A detailed description of this facility is presented in Section 4.0 of this report. Results of the large-scale tests include infiltration, seepage, and drainage during and after simulated storms, in situ hydraulic conductivities, engineering properties of core samples, in situ chemical analyses, and measurements of the in situ state of stress.

The results of all research conducted between October 1986 and December 1993 are included in this final report. 


\section{OBJECTIVE 1.0}

Assess the infiltration and movement of water and the potential for development of saturated zones and drainage, under natural and simulated climatic conditions;

1.1 Determine initial saturated and unsaturated hydraulic properties for the processed oi shale and describe effects caused by hysteresis and by changes in exchangeable sodium percentage which could occur through leaching.

1.2 Determine infiltration rates of precipitation into disposed processed oil shale lifts and describe the effects of storm duration, storm intensity, antecedent water content by profile depth, and vertical hydraulic gradient.

1.3 Determine the distribution of soil moisture as a function of profile depth and time and evaluate changes in storage with time.

1.4 Determine the direction and cumulative flux of water as a function of profile depth and time.

1.5 Determine saturated and unsaturated hydraulic properties for processed oil shale after disposal and weathering under climatic conditions.

1.6 Assess differences in the measured hydraulic properties from 1.1 and 1.5 above.

\section{OBJECTIVE 2.0}

Assess the movement of solubles and major chemical constituents under natural and simulated climatic conditions.

2.1 Determine the initial chemical composition and total quantity of solubles present in the processed oil shale. 
Table 1.1 (continued)

2.2 Determine the distribution of solubles and analyze the major chemical constituents as a function of profile depth and time during the operation of field and laboratory lysimeters.

2.3 Determine the direction and cumulative flux of solubles as a function of profile depth and time during climatic simulation.

2.4 Determine the final chemical composition and total quantity of solubles remaining as a function of profile depth in the processed oil shale after completion of disposal and weathering by climatic simulation.

\section{OBJECTIVE 3.0}

Assess the physical and constitutive properties (index properties, shear strength, stressstrain properties and compressibility) of the oil shale solid waste and determine potential changes in these properties caused by disposal and weathering by natural and simulated climatic conditions.

3.1 Determine the initial physical and constitutive properties of the processed oil shale.

3.2 Determine the physical and constitutive properties of the processed oil shale as a function of profile depth in the lysimeters during and after completion of weathering by simulated climatic conditions.

3.3 Assess any measured differences between the initial and final physical and constitutive properties of the processed oil shale solid waste after being subjected to natural and simulated climatic conditions. 
3.4 Evaluate relationships between the physical and constitutive properties of processed oi shale and its chemical/mineralogical characteristics.

\section{OBJECTIVE 4.0}

Assess the applicability of available computer model(s) to quantify the infiltration, seepage, and drainage of water from spent shale waste embankments.

4.1 Assess differences between measured physical data observed in the lysimeters and data estimated by computer model under the boundary conditions and simulated climatic conditions were applied to the lysimeter plots.

\section{OBJECTIVE 5.0}

Evaluate the stability of field scale processed oil shale solid waste embankments using computer models.

5.1 Obtain and evaluate commercially available computer codes that will enable realistic evaluation of factors of safety against slope instability.

5.1 Model the stability behavior of processed oil shale solid waste embankments, taking into account the construction, adjustment, long-term and transient stages of embankment service life. 


\subsection{REVIEW OF PREVIOUS WORK}

Experience with full-scale field disposal of spent shale is limited, because large-scale development of western oil shale resources has not occurred to date. Nevertheless, bench-scale research has been conducted on the engineering properties of various spent shales in conjunction with small-scale development projects, for large-scale development which subsequently did not take place, and for research sponsored by government agencies. This chapter is a review and summary of previous work on characterizing the properties and behavior of spent shale for disposal purposes.

\subsection{Overview of Spent Shale Processing Methods}

Western oil shale contains kerogen, a solid hydrocarbon derived from organic materials deposited with fine-grained sediments that make up the mineral matrix. When subjected to sufficient heat, kerogen yields distillable oil. The process of extracting oil from oil shale is referred to as retorting. There are two categories of retorting processes, direct heating and indirect heating. In the direct process, hot gases resulting from combustion of carbonaceous material in the oil shale are recirculated through the retort chamber. The Lurgi-Ruhrgas and Paraho processes are examples of direct heat retorting. The Lurgi-Ruhrgas process was used to generate the spent shale used in this study. In the indirect process, heat is transferred to the shale by contact with externally heated, re-usable solids. The Tosco process is an example of indirect heating. Efficient burning of carbon in the direct heating process results in relatively low amounts of carbon in the solid wastes, reducing the potential for release of pollutants to the environment upon disposal.

\subsection{Disposal of Spent Shale}

A mature oil shale industry would be expected to produce approximately 130 million tons of retorted or processed shale per day (Heistand and Holtz, 1980). The potential for recycling the 
retorted shale is small. Therefore, it becomes important to dispose of the solid wastes in an environmentally acceptable manner.

\subsubsection{Major Considerations}

Disposal location, stability of waste embankments, and mitigation of the effects of spent shale leachates are three major aspects of the disposal problem. One potential disposal location would be the surface or subsurface oil shale mines. However, spent shale bulk volume is approximately 25 percent greater than the original unmined, or raw, volume (Cook, 1974). Volume increase is due to increased pore volume that occurs during the mining and grinding processes. Thus, even if the original mine is completely filled with spent shale, a considerable portion must still be disposed by other means. Furthermore, backfilling of spent shale in mining locations close to an existing water table presents a potential source of ground water pollution and there are questions about the environmental acceptability of underground disposal. An alternative to mine-filling is emplacement of solid wastes in canyons near the retorting operation or using the spent shale for productive purposes such as road bases (e.g., Turner, 1994), waste disposal dams, and embankments. In addition to the challenges noted above, erosion by water and wind must be considered in the design of surface disposal facilities. Effective surface treatment to minimize erosion may consist of measures such as contouring, drainage ditches, and construction of an engineered cover with appropriate vegetation.

Most oil shale retorting processes also generate significant amounts of liquid wastes. Since moisture is needed for compacting the spent shale and for dust control, co-disposal of liquid and solid wastes could reduce the need for higher quality water which would otherwise be obtained from surface and groundwater sources (McWhorter and Durnford, 1987).

It has been postulated that spent shale waste embankments in the Piceance Creek Basin, Colorado could be as high as $305 \mathrm{~m}$ to $460 \mathrm{~m}(1,000$ to 1,500 feet) and have a volume greater than 
any man-made structure. Physical stability of embankments of such magnitude becomes a critical concern. To minimize the required surface area, it is necessary to construct embankments with slopes as steep as possible within the slope angle that is considered safe (Rothwell, 1989). Physical properties such as shear strength and compressibility therefore are critical parameters needed for embankment analysis and design.

Retorted shales may contain chemicals that present the potential for leaching and that could have an adverse impact on ground water beneath disposal sites (McWhorter and Durnford, 1987). An understanding of the volume and rate of flow through processed shale is important for proper disposal. Hydraulic conductivity of spent shale therefore becomes another important parameter required for engineered design.

\subsection{Review of Spent Shale Physical and Engineering Properties}

Properties of spent shale needed for environmentally safe disposal include physical and index properties such as gradation and compaction characteristics, and engineering properties, including consolidation, strength, and hydraulic conductivity.

\subsubsection{Gradation and Index Properties}

The gradation of spent shale provides an indication of its suitability for engineering applications. Spent shale gradation varies with the type of retorting (Snethen et al., 1978), but a common characteristic of all spent shales is significant percentages of non-plastic silt. Depending upon the amount of gravel present and the plasticity of the fines, most spent shale would be classified as silty gravel (GM), silty sand (SM), or sandy silt (ML) under the USCS system (Table 21). These classification groups are generally rated as having good compaction characteristics, good to excellent strength, low plasticity, and as being good foundation materials. Specific gravity of spent shale solids ranges from 2.52 to 2.67 (Snethen et al., 1978; Peterson et al., 1978). 
Table 2.1 Range of Geotechnical Properties of Spent Shale

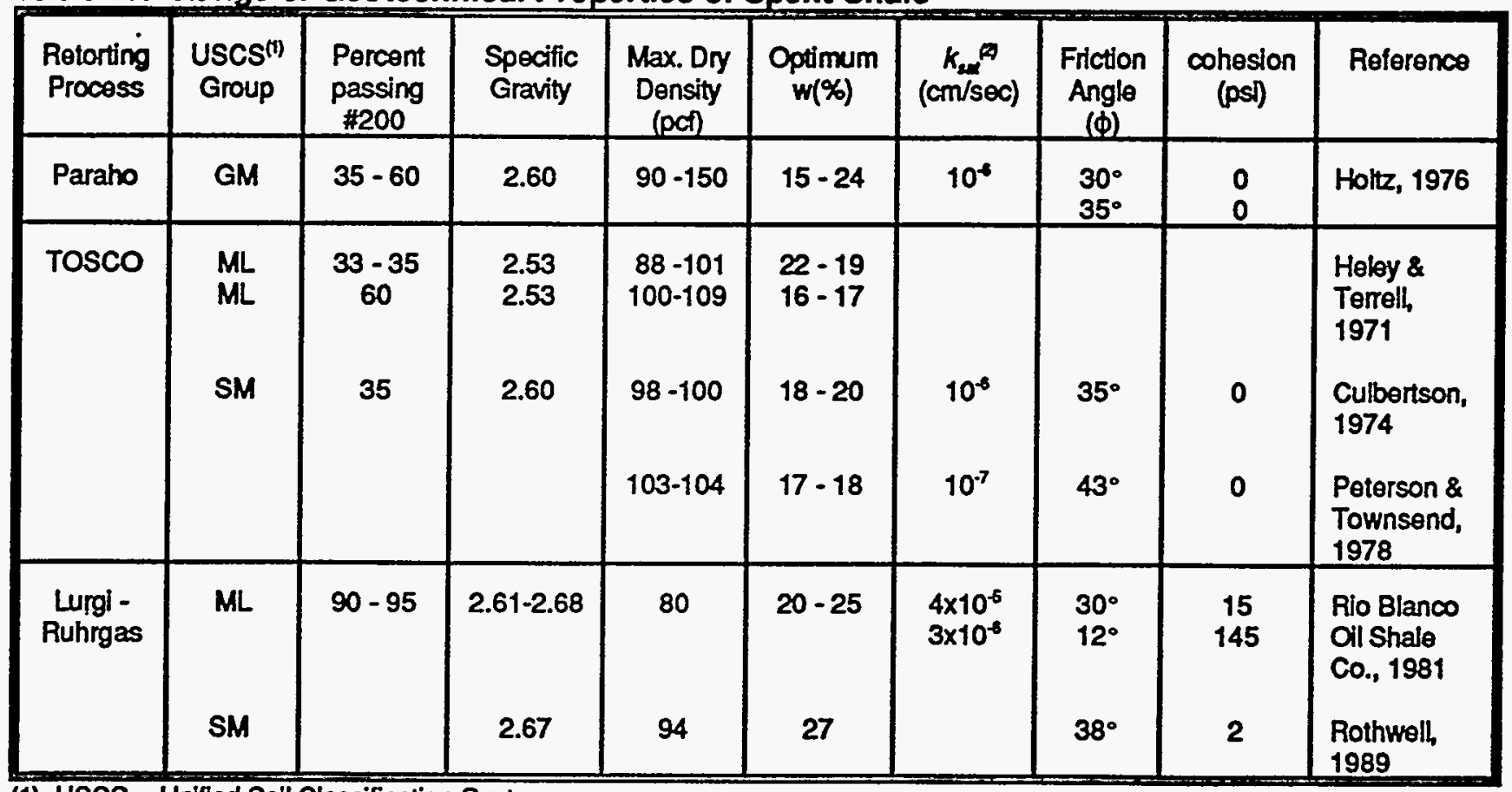

(1) USCS = Unifled Soll Classification System

(2) $k_{2 x}=$ saturatod hydraullic conductivity

\subsubsection{Compaction Characteristics}

Numerous laboratory compaction tests have been performed on various spent shales at different compactive efforts. Test results indicate that, as for most soils, with higher compactive effort, density increases and optimum water content decreases. Typical ranges of values for maximum dry density and optimum moisture content are given in Table 2.1.

\subsubsection{Shear Strength}

Shear strength of spent shale has been determined in laboratory tests by unconfined compression and/or triaxial shear tests. Because of the cementitious characteristics of spent shale, shear strength has been observed to increase by a factor of 3 to 8 with curing time (Farris,1979). Reported values of the strength parameters friction angle $(\phi)$ and cohesion $(c)$ are summarized in Table 2.1. 


\subsubsection{Hydraulic Conductivity}

Laboratory and field hydraulic conductivity tests have been conducted on several types of spent shales at different compactive efforts. Falling head permeability tests conducted on Lurgi processed spent shale specimens by Sri Ranjan et. al (1989) in a triaxial cell under confining stress showed a significant decrease in saturated hydraulic conductivity with increasing dry density, curing time, and initial moisture content. Field hydraulic conductivity tests have indicated much higher permeabilities than laboratory specimens.

Laboratory Testing. Laboratory tests conducted on spent shale from the Green River formation do not indicate any definite trend in the variation of hydraulic conductivity (Snethen, Farrell, \& Townsend, 1978). However, it was observed in general that hydraulic conductivity decreases with increasing density and increased percent of fines. Hydraulic conductivity was found to vary between $1.25 \times 10^{8} \mathrm{~cm} / \mathrm{sec}$ at $Y=15.55 \mathrm{kN} / \mathrm{m}^{3}(98.9 \mathrm{pcf})$ to $1.30 \times 10^{-4} \mathrm{~cm} / \mathrm{sec}$ at $Y=12.11 \mathrm{kN} / \mathrm{m}^{3}(77.0 \mathrm{pcf})$.

Heistand and Holtz (1980) conducted hydraulic conductivity tests on Paraho spent shale classified as sitty gravel (GM). It was observed that hydraulic conductivity decreased with increasing compactive effort. Three loads equivalent to vertical stresses of 345,690 , and $1379 \mathrm{kN} / \mathrm{m}^{2}(50,100$, and $200 \mathrm{psi}$ ) were applied to the specimen to simulate the overburden from spent shale at depths of 25,50 and $100 \mathrm{~m}(82,164$, and 328 feet) in a typical disposal pile. For standard Proctor compaction at optimum moisture content, saturated hydraulic conductivity $\left(k_{\text {sal }}\right)$ was found to be 0.8 $\times 10^{-8} \mathrm{~cm} / \mathrm{sec}$, while the specimen compacted using the modified Proctor apparatus yielded $k_{\text {set }}=0.6$ $\times 10^{-8} \mathrm{~cm} / \mathrm{sec}$. Since the values of $k_{\mathrm{sat}}$ are very close to $1 \times 10^{-7} \mathrm{~cm} / \mathrm{sec}$, the material was considered by the authors to be suitable for impervious retention embankments and liner construction.

Gates (1982) presented the results of hydraulic conductivity tests on Paraho spent shale compacted to densities of 60 percent of standard Proctor, standard Proctor, and modified Proctor. It was observed that hydraulic conductivity decreased with decreasing void ratio. Hydraulic 
It was observed that hydraulic conductivity decreased with decreasing void ratio. Hydraulic conductivity was observed to decrease by one order of magnitude, from $10^{-3} \mathrm{~cm} / \mathrm{sec}$ at 60 percent of standard Proctor compactive effort, to $10^{-4} \mathrm{~cm} / \mathrm{sec}$ using the modified Proctor procedure at normal (100 percent) effort. Hydraulic conductivity tests conducted on consolidation test specimens showed values of the order of $10^{-6} \mathrm{~cm} / \mathrm{sec}$, possible due to lower void ratios and higher consolidation stresses. Hydraulic conductivity tests conducted by Woodward-Clyde Consultants on $20 \mathrm{~cm}(7.87$ in) diameter specimens of Paraho spent shale showed hydraulic conductivities on the order of $10^{-5}$ to $10^{-7} \mathrm{~cm} / \mathrm{sec}$, possibly due to higher percentages of fines present in the material (Gates, 1982).

Gates (1982) also reported results of hydraulic conductivity tests on Paraho spent shale conducted at Pacific Northwest Laboratory. A $2 \mathrm{~m}$ (6.56 feet) high, $0.18 \mathrm{~m}$ (7 in) square column, and a $0.15 \mathrm{~m}$ (6 in) high, $0.15 \mathrm{~m}$ ( 6 in) diameter cylindrical cell were packed at low and high dry densities (13.68 $\mathrm{kN} / \mathrm{m}^{3}$ or $87.0 \mathrm{pcf}$ and $15.16 \mathrm{kN} / \mathrm{m}^{3}$ or $96.4 \mathrm{pcf}$, respectively). It was observed that for low density packing, hydraulic conductivity was of the order of $10^{-3} \mathrm{~cm} / \mathrm{sec}$. For high density packing it was of the order of $10^{-5} \mathrm{~cm} / \mathrm{sec}$.

Stewart (1982) conducted special hydraulic conductivity tests and image processing on samples from a Lurgi-Ruhrgas spent shale column to determine downward migration of fine particles and plugging of pore spaces. Two columns of $7 \mathrm{~cm}$ (2.75 in) diameter, $46 \mathrm{~cm}$ (18 in) long, were subjected to 30 days of leaching under heads of $31 \mathrm{~cm}$ (12 in) and $152 \mathrm{~cm}$ (60 in). Following the leaching period, each column was cut into three $15 \mathrm{~cm}(6$ in) long specimens and hydraulic conductivity tests were conducted on each. Test results indicated that for both columns, the top and middle sections had a hydraulic conductivity on the order of $10^{-8} \mathrm{~cm} / \mathrm{sec}$. The bottom section had a hydraulic conductivity on the order of $10^{-7} \mathrm{~cm} / \mathrm{sec}$.

After the hydraulic conductivity tests were completed, $2.54 \mathrm{~cm}$ square specimens were cut from each section parallel to the direction of flow for image processing. Each specimen was embedded by a low viscosity medium, set into a plastic plug, ground and polished on one surface 
tests indicated no migration of fines. Also, since the difference in hydraulic conductivity among the sections was not very significant, it was concluded that cementation was the cause of plugging.

McWhorter and Brown (1985) conducted a series of hydraulic conductivity tests on retorted oil shale obtained from various processes, including Lurgi-processed spent shale. Saturated hydraulic conductivity of the Lurgi spent shale was determined by conducting a falling head permeameter test in a $53 \mathrm{~cm}$ (20.87 in) high, $6.95 \mathrm{~cm}$ (2.74 in) diameter column in which the spent shale was compacted to a dry unit weight of $13.44 \mathrm{kN} / \mathrm{m}^{3}(85.5 \mathrm{pcf})$ at 20 percent water content by weight. The spent shale was allowed to saturate overnight by upward flow from the bottom. Measured $k_{\text {se }}$ was found to be $9.4 \times 10^{-6} \mathrm{~cm} / \mathrm{sec}$. For Tosco II processed shale, $k_{\text {set }}$ was determined from several constant head and falling head permeability tests conducted on specimens compacted to a dry unit weight of $15.4 \mathrm{kN} / \mathrm{m}^{3}$ (97.97 pcf) at a gravimetric water content of 21 percent. The average saturated hydraulic conductivity was found to be $6.5 \times 10^{-5} \mathrm{~cm} / \mathrm{sec}$. A series of constant head and falling head permeameter tests was conducted to determine $k_{\text {set }}$ of Paraho processed shale. Spent shale was compacted into the permeameter in $5 \mathrm{~mm}$ lifts at a dry unit weight of 16.68 $\mathrm{kN} / \mathrm{m}^{3}$ (106 pct) at 20 percent water content. An average saturated hydraulic conductivity of $5 \times 10^{-7}$ $\mathrm{cm} / \mathrm{sec}$ was obtained. For Hytort processed shale, two sets of constant head tests were conducted to determine $k_{\text {sell }}$. In the first test, the spent shale was compacted to a dry density of $16.68 \mathrm{kN} / \mathrm{m}^{3}$ (106 pcf) at 18 percent water content. Average $k_{\text {set }}$ was $1.5 \times 10^{-5} \mathrm{~cm} / \mathrm{sec}$. In a second set of tests, average $k_{\text {sat }}$ of $2.5 \times 10^{-3} \mathrm{~cm} / \mathrm{sec}$ was measured when the spent shale was compacted to a dry density of $14.72 \mathrm{kN} / \mathrm{m}^{3}$ (93.6 pcf) at 10 percent water content.

McWhorter and Nazarath (1984) conducted laboratory tests to determine the capillary waterholding capacity and hydraulic conductivities of several retorted oil shales. Capillary water-holding capacity was determined using a 15 -bar pressure-plate apparatus. To measure $k_{\text {sat }}$ a $10 \mathrm{~cm}(4 \mathrm{in})$ high, $20 \mathrm{~cm}$ (8 in) diameter constant head permeameter was used which permitted simulation of overburden stress by a hydraulic jack and a load spring on the specimen. Just as in a commercial 
application, where the spent shale would most likely be placed at a moisture content determined by the amount of water required for compaction, cooling, and dust control, the spent shale was mixed at the required water content and packed in the permeameter in four $2.54 \mathrm{~cm}$ ( 1 in) lifts with a standard weight hammer. A simulated overburden pressure was applied using the hydraulic jack. $k_{\text {eat }}$ was measured as a function of time up to one week or more. The measured $k_{\text {sax }}$ ranged from $10^{-7} \mathrm{~cm} / \mathrm{sec}$ for Paraho spent shale to $10^{-3} \mathrm{~cm} / \mathrm{sec}$ for Hytort spent shale.

Elfects of Cementation. An important aspect of spent shale behavior is that engineering properties are time-dependent, primarily because of cementation. Spent shale is highly. reactive and hydrates on contact with water resulting in formation of cementitious compounds. This changes the internal pore structure and therefore affects hydraulic conductivity. Tests conducted on retorted oil shale cured at saturated conditions have cemented similar to cured concrete (McWhorter, 1987). X-ray diffraction studies by Marcus et al. (1984) and a Scanning Electron Microscope micrograph study by McWhorter and Brown (1985) serve to illustrate this behavior.

Marcus et al. (1984) prepared $10 \mathrm{~cm}$ (4 in) high, $5 \mathrm{~cm}$ (2 in) diameter laboratory specimens using the Harvard miniature compaction apparatus to study the effect of cementation on spent shale hydraulic conductivity. Specimens were compacted with 20 percent weight of distilled or retorted water and cured from 1 to 105 days. It was observed that only 5.0 to 5.5 percent of water was involved in cementitious reactions.

McWhorter and Brown (1985) conducted laboratory tests on six $40 \mathrm{~g}$ samples mixed at different water contents to study the effect of water content and time on hydration. Specimens were cured at $22^{\circ} \mathrm{C}$ for 15 days and then oven dried at $104^{\circ} \mathrm{C}$ for 24 hours. These specimens were found to retain a maximum of 3.6 percent water by weight due to hydration. To study the effect of time on hydration, $40 \mathrm{~g}$ samples were mixed at 30 percent water by weight and cured at 22 degrees $C$ at 100 percent relative humidity. These specimens were then oven dried for $1,2,5,28,55$, and 
C at 100 percent relative humidity. These specimens were then oven dried for $1,2,5,28,55$, and 89 days to determine the amount of hydrated water. At about 28 days, the maximum hydrated water content of 3.6 percent was observed. Beyond 28 days, there was no further hydration. It was concluded that only a small portion of material reacts during cementation.

Since the long term hydraulic properties of shale were of concern, only 28-day hydrated specimens were used in hydraulic conductivity tests. The hydrated samples were crushed and remixed to replicate initial particle size distribution and packed into columns at different water contents ranging from 20 to 42 percent by weight at dry unit weights ranging between $9.32 \mathrm{kN} / \mathrm{m}^{3}$ and $12.75 \mathrm{kN} / \mathrm{m}^{3}$ (59.28 pcf and $\left.81.12 \mathrm{pcf}\right)$. Saturated hydraulic conductivity was determined using a permeameter over a period of 270 days. For specimens mixed at $20 \%$ water content, the saturated hydraulic conductivity was found to decrease by four orders of magnitude after 100 days. Specimens mixed at close to saturation exhibited greater reduction in hydraulic conductivity. McWhorter and Brown concluded that near saturation conditions are ideal for promoting maximum hydration and maximum reduction in hydraulic conductivity.

To predict the impacts of leachate on surface and ground water, it is first necessary to predict seepage rates in retorted shale. A number of simple and complex numerical simulations have been performed to predict the quantity and rate of leachate in processed shale. However, none of the simulation studies reported in the literature account for potential effects of cementation on spent shale hydraulic conductivity.

Field Testing. In 1976, several concrete lysimeters were constructed to aid in modeling a disposal scheme for Paraho spent shale and to measure the quality and quantity of leachate which might result from a processed shale disposal pile (Kilkelly et al., 1981). The lysimeters were designed to simulate a canyon fill disposal site by constructing a highly compacted fill with a gentle upstream slope, steep downstream slope, and a soil cover adequate for moisture storage and plant rooting. 
Two sets of lysimeters were constructed at the site. A sprinkler irrigation system was used to simulate precipitation. The lysimeters were instrumented to monitor moisture movement and subsurface drains were installed in each lysimeter to collect leachate in order to measure the total volume and the rate at which seepage was occurring. Results reported for one of the lysimeters containing Paraho spent shale on a 25 percent slope produced one pore volume of leachate. A decrease of infiltration rate from $1.08 \times 10^{-3} \mathrm{~cm} / \mathrm{sec}$ during the first year to $2.50 \times 10^{-4} \mathrm{~cm} / \mathrm{sec}$ over the next two years was observed.

Another set of field studies was conducted during Phase VII of the Paraho Oil Shale Project to determine hydraulic conductivity of retorted shale. Two filtration ponds, one with a compacted liner and the other with an uncompacted liner, were constructed to monitor seepage and evaporation. The uncompacted liner was found to have a higher hydraulic conductivity $\left(k=1.2 \times 10^{-4}\right.$ $\mathrm{cm} / \mathrm{sec})$ than the compacted liner $\left(k=2.65 \times 10^{-7} \mathrm{~cm} / \mathrm{sec}\right)$.

Heistand and Holtz (1980) conducted field hydraulic conductivity tests on Paraho retorted shale using two infiltration ponds. Pond 1 consisted of retorted shale mixed with water at optimum moisture content and subjected to heavy compactive effort in $20 \mathrm{~cm}$ (8 in) thick layers in order to model a highly compacted, high strength, low permeability material that would be used to construct a retention embankment. Pond 2 consisted of loose fill compacted with normal hauling and spreading equipment, representing a loose fill behind an embankment and above the liner. Both ponds had side slopes of 2:1 (horizontal:vertical) and drain lines installed in trenches in the subgrade to collect and measure seepage water. For Pond 1, the retorted shale was mixed at a gravimetric water content of 20 percent, graded in $20 \mathrm{~cm}$ ( 8 in) thick layers compacted with seven passes of a heavy vibratory roller.

Following construction, water was added to the ponds and infiltration rates were measured using a staff gauge. Water which passed through the drain lines was also measured. Ten cores were taken from Pond 1 for laboratory examinations. The staff-measured infiltration rates for Pond 
initial adsorption were not considered, somewhat smaller infiltration rates were likely. Cores taken from Pond 1 had an average laboratory hydraulic conductivity of $5.7 \times 10^{-7} \mathrm{~cm} / \mathrm{sec}$, approximately one order of magnitude lower than the field-measured infiltration rates. The discrepancy may have been due in part to failure to account for evaporation and the initially unsaturated state of the spent shale in the field.

A rainfall simulation test was conducted on pond 2 several months after the infiltration test, when it had dried thoroughly. About 17,400 l of water was sprayed on the surface to simulate rainfall of $5 \mathrm{~cm}$ in 30 minutes. Approximately $27 \mathrm{I}$ of seepage water was collected from the drain pipe after one day. It was concluded by Heistand and Holtz (1980) that leaching does not pose a problem in Paraho spent shale even when lightly compacted, if properly managed.

\subsection{Modeling Studies}

\subsubsection{Analysis of a Hypothetical Spent Shale Disposal System}

Bloomfield and Stewart (1981) presented a preliminary engineering analysis of a spent shale disposal system, including stability analyses. The spent shales used in the study were retorted by Paraho and Tosco processes. Comprehensive laboratory test data determined by Townsend and Petersen (1979) were used for the design procedure. Determination of physical properties included gradation curves, Atterberg limits, and specific gravity. Engineering properties included moisturedensity relationships (compaction test), consolidation, unconfined compressive strength, triaxial compressive strength, direct shear strength, and hydraulic conductivity. The oil shale was retorted in the laboratory under controlled retort temperature and residence time.

Compaction characteristics of Paraho spent shale were studied by conducting four sets of tests at compactive efforts corresponding to: (i) 60 percent of standard Proctor, (ii) standard Proctor, (iii) modified Proctor compaction, and (iv) vibratory compaction. Results indicated that maximum dry density achieved by vibration was considerably lower than the maximum achieved by 
maximum dry density achieved by vibration was considerably lower than the maximum achieved by only 60 percent of standard Proctor compactive effort. These results indicate vibratory compaction is not an efficient means for achieving high density, at least for the spent shales used in the study. But field compaction tests reported by Holtz (1976) showed that maximum density of Paraho spent shale was achieved by a vibrating drum roller. The apparent discrepancy may be explained by differences between laboratory and field vibratory compaction. A vibrating drum roller densifies soil by a combination of high mass and vibratory energy, while the laboratory procedure may have depended on vibratory energy only.

Unconfined and triaxial compression tests showed shear strength increasing with increases in curing time and with increasing initial water content. Strength increases were attributed by the authors to cementation, which is time-dependent and increases in proportion to the amount of water available.

Hydraulic conductivity tests conducted on triaxial specimens of Paraho spent shale prior to triaxial compression tests showed a decrease in hydraulic conductivity from $10^{-3} \mathrm{~cm} / \mathrm{sec}$ at 60 percent of standard Proctor compaction to $10^{-4} \mathrm{~cm} / \mathrm{sec}$ at modified Proctor compactive effort. In the case of Tosco spent shale, hydraulic conductivity decreased from $10^{-6} \mathrm{~cm} / \mathrm{sec}$ at 60 percent of standard Proctor compaction to $10^{-7} \mathrm{~cm} / \mathrm{sec}$ at modified Proctor compactive effort.

A computer code developed by Bloomsburg and Wells (1978) was then used to determine the unsteady, unsaturated flow characteristics of water through spent shale. Engineering properties used as input were obtained from the laboratory testing described above, laboratory test results reported previously by Townsend and Peterson (1979), and field measurements of hydraulic conductivity made at two seepage ponds reported by Heistand and Holtz (1980).

Two disposal systems were studied: (1) backfilling the mine and (2) surface disposal. The study of mine backfilling was limited to a cost comparison between mechanical, hydraulic, and pneumatic methods of transportation and placing spent shale underground. The surface disposal 
system consisted of an embankment and a cross-valley fill $573 \mathrm{~m}$ (1,880 feet) wide by $91 \mathrm{~m}$ (300 feet) deep, as shown in Figure 2.1. Spent shale in the embankment was assumed to be compacted to a dry unit weight of $14.94 \mathrm{kN} / \mathrm{m}^{3}$ (95 pcf) at 25 percent water content and the fill to $13.36 \mathrm{kN} / \mathrm{m}^{3}$ (85 pcf) at 20 percent water content. Three types of boundary conditions were applied at the ground surface: (1) the 100-year rainstorm for a duration of one hour, (2) the 100-year rainstorm for a duration of six hours, and (3) a ponded condition. The 100-year storms were simulated to determine whether rainwater would infiltrate the waste pile or run off the surface. Neither rainstorm produced any runoff over the fill, whereas a significant amount of runoff was observed over the embankment, indicating that runoff could be expected if the spent shale is compacted to a high density. Analysis

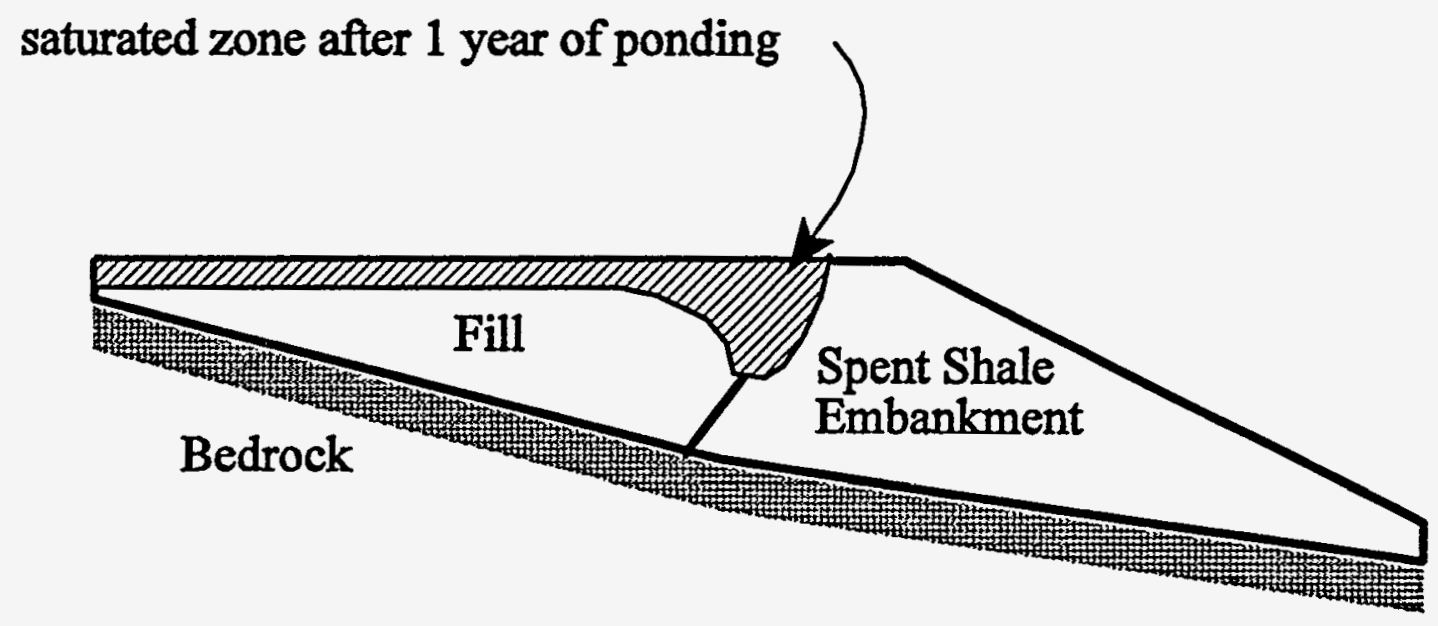

Figure 2.1 Typical cross-valley fill and simulated saturation zone after one year of ponding. (Adapted from Bloomfield and Stewart, 1981) 
also showed that the quantity of leachate from the embankment or fill would be so small that it would not appear to contaminate surface or ground water. The third seepage boundary condition consisted of $1.5 \mathrm{~m}$ (5 feet) of water ponded on the surface for a period of one year, and no infiltration or evaporation on the remainder of the pile. The simulation suggested that impounding water on the surface would saturate the spent shale, resulting in seepage of leachate, indicating the need to consider protection of surface and ground water.

Slope stability analyses were performed using Bishop's method for dry and saturated cases. Factors of safety of 1.67 for the dry state and 0.85 for the saturated state were obtained. The authors state that the unstable saturated condition indicates there is a need to provide an impervious core or drainage facility to prevent saturation with a resulting high-phreatic surface.

\subsubsection{Simulation of Water and Solute Movement}

Wildung et al. (1982) employed a one-dimensional unsaturated groundwater flow model to estimate water and solute movement in a conceptual embankment shown in Figure 2.2. The computer model was utilized to simulate water movement during construction and for a period of twenty-five years after completion of construction. The model embankment was $\mathbf{5 0} \mathbf{m}$ high, constructed of Paraho spent shale in five, $10 \mathrm{~m}$ thick lifts over a period of five years. A $5 \mathrm{~m}$ layer of soil was assumed to exist between the lower layer of spent shale and the ground water. The lowest $5 \mathrm{~m}$ of spent shale was assumed to be compacted to a dry unit weight of $14.2 \mathrm{kN} / \mathrm{m}^{3}(90 \mathrm{pcf})$, to simulate a liner. The remainder of the spent shale was assumed to be compacted to a dry unit weight of $11.8 \mathrm{kN} / \mathrm{m}^{3}$ (75 pcf) and capped with $0.5 \mathrm{~m}$ of Nihill Channery Loam, which is a mixture of Green River and Wasatch alluvium. Initial water contents were assumed to be either 15 percent or 26-30 percent, depending on the unit weight of the spent shale, as given in Table 2.2. The relationship between moisture content and hydraulic conductivity was computed by empirical methods. Boundary conditions of precipitation and evaporation at the surface and water table at the 


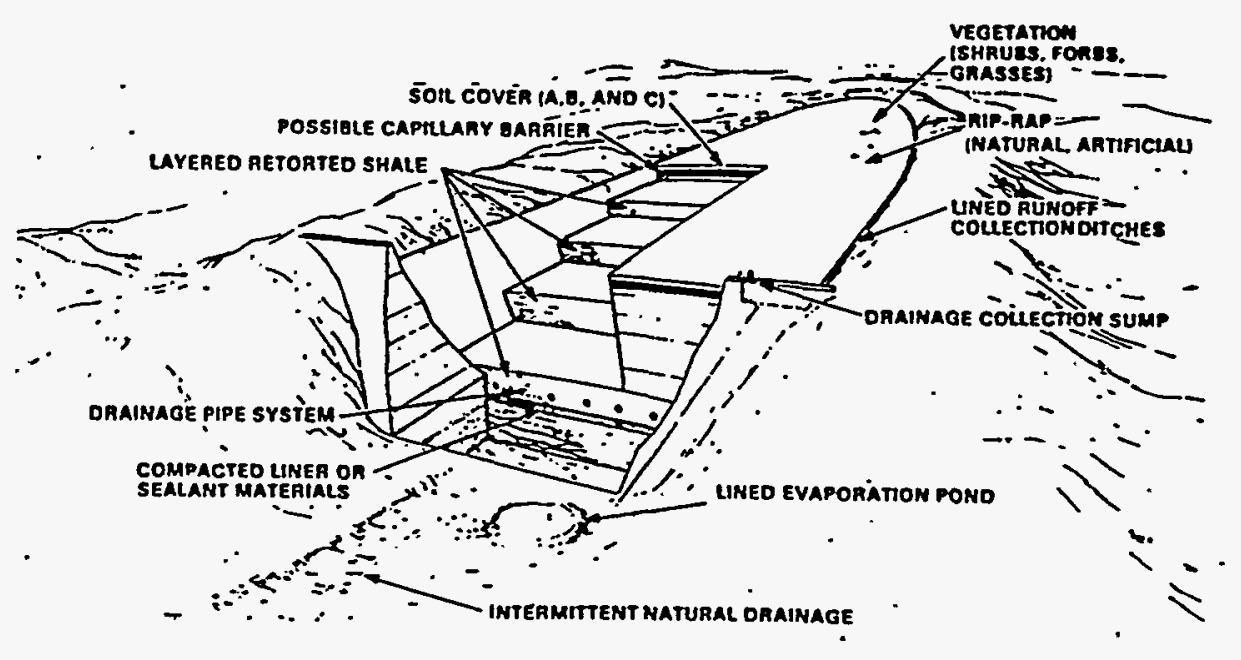

Figure 2.2. A conceptual retorted shale embankment at the head of the canyon (Wildung et al., 1982)

base of the embankment were assumed. Actual hourly precipitation data recorded in 1979 were applied for multi-year simulation.

When retorted shale was compacted at a water content of 15 percent, the model predicted a gain in water from the surface and from the water table, because of higher suction head and additional storage capacity. No drainage was predicted for the thirty year simulation period. When spent shale was compacted at a water content of $w=30$ percent, which is closer to saturation, there was no significant increase in water content, but drainage was observed. Water profiles were plotted for both cases and are summarized in Table 2.3. When the cumulative water flux from the embankment was examined at various depths annually, it was observed in Case 1 that there was no drainage below a depth of $30 \mathrm{~m}$ after 30 years. For Case 2 , maximum drainage occurred at the base of the embankment. For the first 10 years, most water moving through the profile was attributed to stored water and not to water entering the surface as rainfall. The same amount of 
Table 2.2 Embankment Initial Moisture Conditions (Wildung et al., 1982)

\begin{tabular}{|c|c|c|c|c|}
\hline & $\begin{array}{c}k_{\text {zat }} \\
(\mathrm{cm} / \mathrm{sec})\end{array}$ & $\begin{array}{c}w / \%)^{(1)} \\
\text { Case } \\
1\end{array}$ & $\begin{array}{c}w / \%)^{(1)} \\
\text { Case } \\
2\end{array}$ & $w_{\text {sat }}{ }^{(2)}$ \\
\hline Soil Cap & $1.2 \times 10^{-4}$ & - & - & 44 \\
\hline $11.8 \mathrm{kN} / \mathrm{m}^{3}$ & $1.12 \times 10^{-2}$ & 15 & 30 & 47 \\
\hline $14.2 \mathrm{kN} / \mathrm{m}^{3}$ & $4.43 \times 10^{-5}$ & 15 & 26 & 40 \\
\hline $\begin{array}{c}\text { Soil } \\
\text { (bottom) }\end{array}$ & $1.2 \times 10^{-2}$ & - & - & 44 \\
\hline
\end{tabular}

(1) $w(\%)=$ water content, as a percent of dry weight

(2) $w_{\text {set }}=$ water content at saturation

Table 2.3 Embankment Water Profile Changes Over Time (Wildung et al., 1982)

\begin{tabular}{|c|c|c|}
\hline Time & $\begin{array}{c}\text { Case } 1 \\
\text { (initial } w=15 \% \text { ) }\end{array}$ & $\begin{array}{c}\text { Case } 2 \\
\text { (initially } w=30 \% \text { ) }\end{array}$ \\
\hline $\begin{array}{l}\text { After } 10 \\
\text { years }\end{array}$ & $\begin{array}{l}\text { Water moved to a } \\
\text { depth of } 20 \mathrm{~m}\end{array}$ & $\begin{array}{c}\text { Perched water table } \\
\text { developed }\end{array}$ \\
\hline $\begin{array}{l}10-15 \\
\text { years }\end{array}$ & Not available & Drainage from base \\
\hline 15 years & Not available & $\begin{array}{c}\text { Approaching steady state } \\
\text { condition }\end{array}$ \\
\hline 20 years & $\begin{array}{c}\text { Water moved to a } \\
\text { depth of } 30 \mathrm{~m}\end{array}$ & Reached equilibrium state \\
\hline $\begin{array}{l}\text { After } 30 \\
\text { years }\end{array}$ & $\begin{array}{c}\text { Water content in } \\
\text { unsaturated shale } \\
\text { increased to } 21-22 \%\end{array}$ & Reached equilibrium state \\
\hline
\end{tabular}


drainage occurred after 20 and 30 years, indicating a steady-state seepage condition had been reached. If the simulations by Wildung et al. (1980) are accurate, they illustrate the importance of initial water content on the potential for leachate from spent shale embankments to reach the groundwater, at least for the thirty year period considered.

\subsection{Summary}

This section presents a review oil shale processing methods, proposed disposal methodologies, and previous studies on the engineering properties of spent shale. Special emphasis is placed on hydraulic conductivity, which several studies have shown to vary over several orders of magnitude as a function of initial moisture content, compacted density, and time. Previous research suggests that cementation may be the most significant factor affecting hydraulic conductivity of spent shale.

Review of the literature reveals that much work still needs to be done to predict accurately how full-scale spent shale waste embankments will behave under service conditions. The study described in the remainder of this report was designed to improve our understanding of how water infiltrates and travels through spent shale waste embankments under simulated and natural climatic conditions. 


\subsection{BENCH-SCALE CHARACTERIZATION OF GEOTECHNICAL PROPERTIES}

The spent shale used in this study was obtained from Rio Blanco Oil Shale Company, Inc. The raw oil shale was mined from the Green River Formation at Federal Tract C-a in the Piceance Creek Basin near Rifle, Colorado and then retorted by the Lurgi-Ruhrgas process. Approximately 200 tons of the spent shale was used to construct field test embankments in lysimeters at the Tract C-a site and another 200 tons was shipped to the University of Wyoming in Laramie for construction of test embankments in the Environmental Simulation Laboratory. This source of spent shale was used to conduct bench-scale laboratory tests for characterizing the physical, chemical, and engineering properties of the spent shale. Design of commercial-scale waste facilities would most likely be based largely on engineering properties measured in bench-scale tests. Therefore, an important aspect of this study was to relate the behavior of the test embankments to engineering properties of the spent shale measured in bench-scale tests. This section of the report describes the methods, procedures, and results of the bench-scale testing program.

\subsection{Materials}

The solid waste product resulting from the Lurgi-Ruhrgas process (referred to herein as Lurgi spent shale or Lurgi-processed shale) consists of two materials, solids collected in surge bins and "dust" collected in flue filters. The surge bin solids, which are coarser than the flue dust, comprise approximately 90 percent by weight of the material. A 90/10 ratio of the surge bin solids to flue filter dust was used for all bench scale tests and analyses.

\subsection{Geotechnical Properties - Methods}

A laboratory testing program was carried out to determine the geotechnical properties of 
Lurgi spent shale that are pertinent to the design of solid waste disposal embankments (Table 3.1). The testing program consisted of index properties, moisture density relationships (compaction tests), consolidated-drained and consolidated-undrained triaxial tests, unconfined compression tests, hydraulic conductivity tests, and tests to determine moisture-characteristic curves. In addition, specimens of the spent shale were weathered artificially to evaluate the potential influence of wet-dry and freeze-thaw cycles on strength and hydraulic conductivity. ASTM standards were followed for all testing procedures, where applicable. Further details are given by Rothwell (1989) and Turner and Rothwell (1991).

Table 3.1. Summary of geotechnical laboratory testing program.

\begin{tabular}{llc}
\hline \multicolumn{1}{c}{ Property } & \multicolumn{1}{c}{ Tests } & No. of Tests \\
\hline Index Properties & Grain-size distribution & 28 \\
& Atterberg limits & 28 \\
Compaction & Moisture-density relationships & 3 \\
Shear strength & CD triaxial & 25 \\
& CU triaxial & 15 \\
& CU triaxial (weathered) & 30 \\
& Unconfined compression & 53 \\
Hydraulic properties & Falling head permeability & 81 \\
& Falling head permeability (weathered) & 64 \\
& Flow pump permeability (weathered) & 64 \\
& Moisture-characteristic curves & 4 \\
\hline
\end{tabular}


To evaluate material variability, twenty-six samples of surge bins solids were obtained randomly from the spent shale source (200 tons). Grain size distribution and Atterberg limits were determined for each sample. In addition, one sample of flue dust (Sample 27) and one sample consisting of 90 percent surge bin solids and 10 percent flue dust (Sample 28) were evaluated for grain size distribution and Atterberg limits. Based on the grain size distribution, the coefficients of uniformity, $c_{u}$, and curvature, $c_{c}$, were determined. These coefficients are defined as:

$$
\begin{aligned}
& c_{u}=D_{60} / D_{10} \\
& c_{c}=\left(D_{30}\right)^{2} /\left(D_{10} \times D_{60}\right)
\end{aligned}
$$

where $D_{10}, D_{30}$, and $D_{60}$ are the grain sizes corresponding to 10,30 and 60 percent passing, respectively.

Atterberg limits testing consisted of liquid limit (LL), plastic limit (PL), and plasticity index (PI). The plasticity index is defined as the difference between the liquid and plastic limits and indicates the range of water contents over which a soil behaves plastically. Based upon grain size distribution and Atterberg limits, each sample was classified according to the Unified Soil Classification System (ASTM 1985).

To evaluate the potential effects of weathering on strength and hydraulic conductivity, specimens of hydrated and compacted spent shale were subjected to wet-dry and freeze-thaw conditions in accordance with ASTM D 559-82, "Standard Method for Wetting-Drying Tests of Compacted Soil-Cement Mixtures" or ASTM D 560-82, "Standard Method for Freezing-and Thawing Tests of Compacted Soil-Cement Mixtures" (ASTM 1985). Specimens were compacted at either $15 \%$ or $27 \%$ water content (by weight) in special soil-cement molds (ASTM 1985) and were $7.1 \mathrm{~cm}$ in diameter and $14.2 \mathrm{~cm}$ high. Two specimens were prepared for each test and then cured for 28 days at $20^{\circ} \mathrm{C}$ and $100 \%$ relative humidity.

In the wet-dry test, the two specimens were submerged in a water bath for five hours. One of the specimens was weighed and measured to determine volume change. The second specimen 
was given two firm strokes on all surface areas with a wire scratch brush and then weighed and measured to determine cement loss as a percentage of initial specimen weight. Both specimens then were placed in an oven at $71^{\circ} \mathrm{C}$ for forty-two hours. Twelve such cycles were applied, in accordance with ASTM (1985). In the freeze-thaw test, the two specimens were maintained at $23^{\circ} \mathrm{C}$ for twenty-four hours. One specimen was brushed and then both specimens were weighed, measured, and laced in a moist room at $20^{\circ} \mathrm{C}$ and $100 \%$ relative humidity for twenty-three hours. Following the completion of twelve cycles of either wetting-drying or freezing-thawing, the hydraulic conductivity of each specimen was measured using both the falling head and flow pump methods, followed by a consolidated undrained triaxial compression test.

A soil moisture characteristic curve describes the relationship between soil water content and capillary pressure (commonly referred to as soil or matrix suction). For this study, soil moisture characteristic curves for the processed shale were used to estimate soil suction in the test embankments from in situ water contents. The estimated soil suctions were used to evaluate hydraulic gradients in the lysimeters. The estimated hydraulic gradients were then used with measured volumetric flux values to back-calculate the hydraulic conductivity of the processed shale according to Darcy's Law. This section describes the tests conducted to obtain characteristic curves for the Lurgi processed shale. Back calculation of hydraulic conductivity is described in later sections of this report.

Two devices were used to determine soil moisture characteristic curves. The first consisted of a 15-bar pressure plate extractor, capable of determining the characteristic curve under draining conditions (decreasing water content) for soil suctions ranging from 0 to 15 bars $(1500 \mathrm{kPa})$. The second apparatus consisted of a $2-b a r(200 \mathrm{kPa})$ pressure plate extractor and was used to develop characteristic curves for both draining and filling conditions. This enabled the measurement of hysteresis on the moisture characteristic curve between 0 and 2 bars. Hysteresis can be described as the difference in soil suction between the draining and filling condition at a given water content. 
Hysteretic effects can occur during one or more draining and filling cycles. Both pressure plates were designed to allow the passage of water up to the rated pressure ( 2 or 15 bars) while restricting the passage of air.

Specimens of spent shale prepared at a water content of $15 \%$ by weight were compacted to a dry density of approximately $13.7 \mathrm{kN} / \mathrm{m}^{3}(89 \mathrm{pcf})$ in molds $5.1 \mathrm{~cm}$ in diameter and $0.6 \mathrm{~cm}$ high. This is the same dry density at which the spent shale was placed in the lysimeters. The 15-bar apparatus could hold three pressure plates to accommodate a total of thirty-six specimens. Figure 3.1 shows a schematic of the 15-bar apparatus. Thirty-six specimens were prepared and placed in the pressure chamber on the porous plates. The pressure chamber was closed and air pressure corresponding to the desired level of soil suction was applied. Because the plates are vented to atmospheric pressure a hydraulic gradient was created across the specimens and the plate. The specimens were left in the chamber until an equilibrium water content was achieved. This was determined by observing the water level of an output burette connected to the plate (Figure 3.1). Two specimens were removed from the chamber after achieving the equilibrium level desired. The removed specimens were dried at $104^{\circ} \mathrm{C}$ and weighed to determine water content. The chamber was closed and pressure corresponding to the next desired increment of soil suction was applied. This process was repeated at 1 bar increments until measurements were obtained between 0 and 15 bars.

The 2-bar apparatus operated on the same principal as the 15-bar apparatus, except that specimens were not removed at each pressure increment. A single specimen was used and the volume of water expelled during each increment of increasing pressure (draining) or absorbed by the specimen as the pressure is decreased (filling) was measured using a highly sensitive burette. The water content corresponding to each pressure increment was calculated from the initial water content and the measured volume of water expelled or absorbed by the specimen. Following the test, the final water content was measured and used to verify the calculated water contents. 


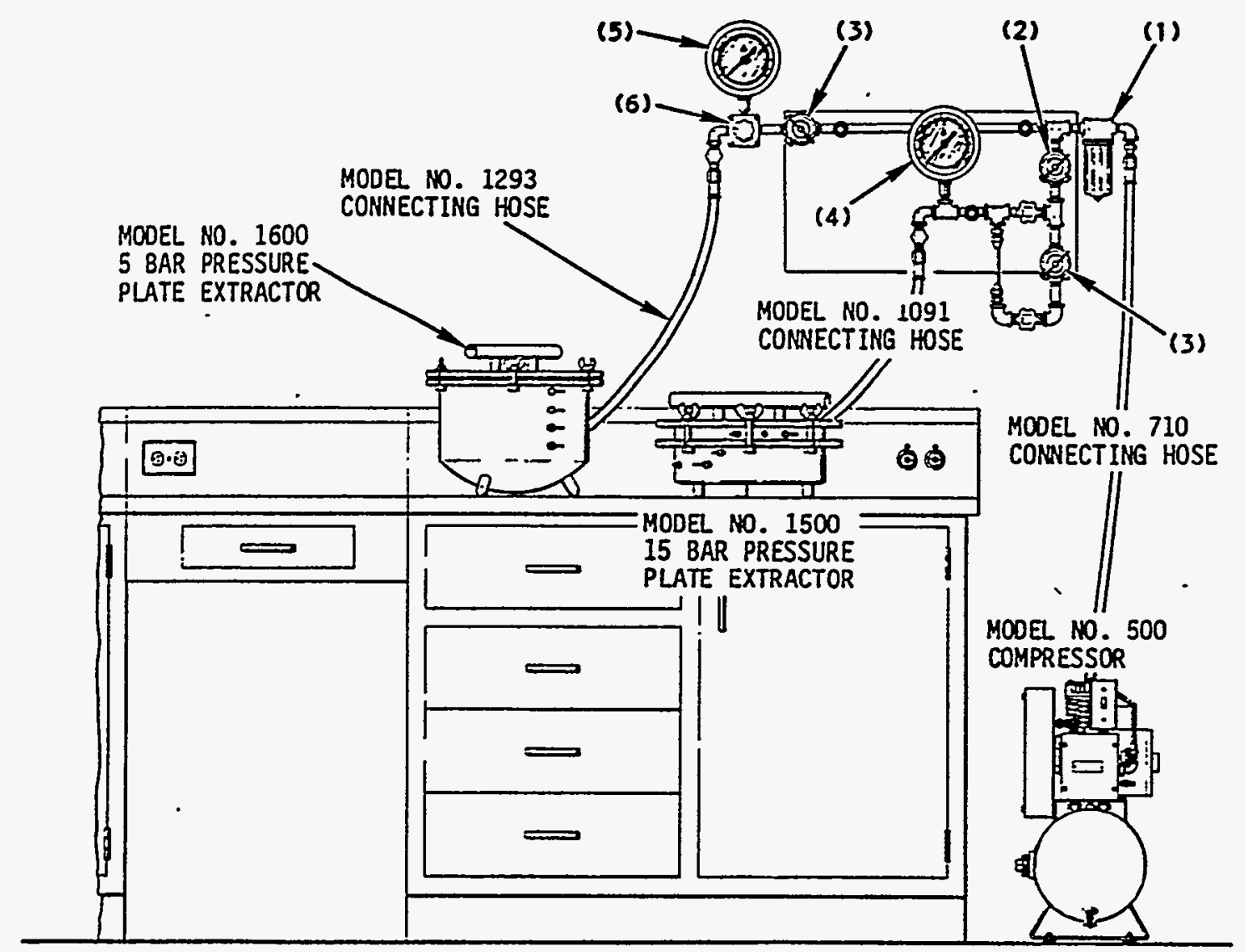

MOOEL NO. 700-23 MANIFOLD, INCORPORATING:

(1) \$760G1 AIR FILTER (FORMERLY \$12-005-013)

(2) \$766P0250 REGULATCR (FORMERLY 11-002-017)

(3) 766P0125 REGULATOR, TWO (FORMERLY 11-002-013)

(4) \$780P0300 0-300 PSI TEST GAUGE (FORMERLY 1082-A)

(5) \$780P0060 0-60 PSI TEST GAUGE (FORMERLY 1082-A)

(6) 765 NULLMATIC REGULATOR (FORMERLY 40-50)

ALL NECESSARY VALVES AND FITTINGS

Figure 3.1. 15-bar pressure plate apparatus. (Source: Soil Moisture Equipment Co., Inc.) 


\subsection{Geotechnical Properties - Results}

\subsubsection{Index Properties}

The coefficients of uniformity and curvature, Atterberg limits, and soil classification are summarized in Table 3.2. For the twenty-six samples of surge bin solids, the mean coefficient of uniformity is 15.5 with a standard deviation of 8.3 , yielding a coefficient of variation of 53.6 percent. The mean coefficient of curvature is 1.8 with a standard deviation of 1.1 and a coefficient of variation of 65.3 percent. Figure 3.2 presents the grain size distribution curves for the surge bin solids. As illustrated by the curves and the coefficients of variation for $c_{u}$ and $c_{c}$, the grain size characteristics of the surge bin solids show a relatively high degree of variability.

The mean liquid limit for the surge bin solids is 33.2 with a standard deviation of 3.4 and a coefficient of variation of 10.3 percent. The mean plastic limit is 34.7 with a standard deviation of 3.8 and a coefficient of variation of 10.9 percent. Within the limit of experimental error, the liquid and plastic limits are equal and, therefore, the spent shale is nonplastic $(P I=0)$. The twenty-six specimens of surge bin solids are classified in Table 3.2 and illustrated graphically in Figure 3.3. Even though the grain size characteristics show a high degree of variability, all of the samples fall into three categories: SP, poorly-graded sand with little or no fines; SM, silty sand; or SW, wellgraded sand with little or no fines (ASTM 1985). Nine samples have a dual classification of SW-SM and three are dual-classified as SP-SM. The flue dust, Sample 27, is classified as ML, silt with sand. The grain size distribution curve of the flue dust (Figure 3.2) shows it is finer grained than the surge bin solids. The material used for all of the remaining tests consisted of 10 percent flue dust and 90 percent surge bin solids, to represent expected production conditions for Lurgi-processed oil shale. The 90-10 mix is classified as SM, silty sand with no plasticity. 
Table 3.2. Index Properties of Lurgi Spent Shale.

\begin{tabular}{|c|c|c|c|c|c|c|}
\hline Sample & $c_{u}$ & $c_{c}$ & $P L^{1}$ & $\mathrm{LL}^{2}$ & $\mathrm{Pl}^{3}$ & uscs \\
\hline 1 & 19.23 & 0.49 & 35.3 & 37.0 & 1.7 & $S M$ \\
\hline 2 & 12.00 & 1.08 & 26.3 & 28.0 & 1.7 & SM \\
\hline 3 & 11.25 & 0.87 & 25.5 & 26.3 & 0.8 & SP-SM \\
\hline 4 & 14.52 & 0.95 & 33.8 & 34.0 & 0.2 & SM \\
\hline 5 & 24.00 & 1.50 & 37.6 & 39.0 & 1.4 & $S M$ \\
\hline 6 & 9.44 & 2.65 & 35.7 & 38.0 & 2.3 & sw \\
\hline 7 & 8.84 & 0.61 & 35.0 & 36.1 & 1.1 & SM \\
\hline 8 & 10.00 & 1.60 & 32.5 & 34.1 & 1.6 & SW-SM \\
\hline 9 & 5.56 . & 1.74 & 34.7 & 37.7 & 3.0 & $S P$ \\
\hline 10 & 6.92 & 2.59 & 33.6 & 35.3 & 1.7 & sw \\
\hline 11 & 9.33 & 2.68 & 37.0 & 39.0 & 2.0 & SW-SM \\
\hline 12 & 10.38 & 2.05 & 29.4 & 30.0 & 0.6 & SW-SM \\
\hline 13 & 15.00 & 0.54 & 36.7 & 39.0 & 2.3 & SM \\
\hline 14 & 6.67 & 2.06 & 25.2 & 26.4 & 1.2 & SW-SM \\
\hline 15 & 16.84 & 1.19 & 31.4 & 32.0 & 0.6 & SW-SM \\
\hline 16 & 25.00 & 2.96 & 33.8 & 35.0 & 1.2 & SW-SM \\
\hline 17 & 17.65 & 2.64 & 33.3 & 35.6 & 2.3 & SW-SM \\
\hline 18 & 22.39 & 2.59 & 35.3 & 36.0 & 0.7 & $S M$ \\
\hline 19 & 15.00 & 5.95 & 30.0 & 31.0 & 1.0 & SP-SM \\
\hline 20 & 36.25 & 2.11 & 36.5 & 38.5 & 2.0 & SM \\
\hline 21 & 5.91 & 1.26 & 33.2 & 33.1 & 0.0 & SP-SM \\
\hline 22 & 12.50 & 1.00 & 33.3 & 36.0 & 2.7 & sw \\
\hline 23 & 17.53 & 1.39 & 36.3 & 38.6 & 2.3 & SW-SM \\
\hline 24 & 9.23 & 1.18 & 32.1 & 34.6 & 2.5 & SW-SM \\
\hline 25 & 33.33 & 1.08 & 35.0 & 37.7 & 2.2 & SM \\
\hline 26 & 27.14 & 0.68 & 34.3 & 35.4 & 1.1 & $S M$ \\
\hline $27^{5}$ & 2.14 & 0.72 & 39.5 & 41.0 & 0.5 & ML \\
\hline $28^{6}$ & 14.17 & 0.95 & 34.6 & 35.5 & 0.0 & $S M$ \\
\hline & $\begin{array}{l}d e x=L L-t \\
d e \text { dust }\end{array}$ & & & $\begin{array}{l}\text { limit } \\
\text { Inified So } \\
3 \text { is } 90 \%\end{array}$ & $\begin{array}{l}\text { ication } S \\
\text { i solids }\end{array}$ & $\%$ flue dust \\
\hline
\end{tabular}




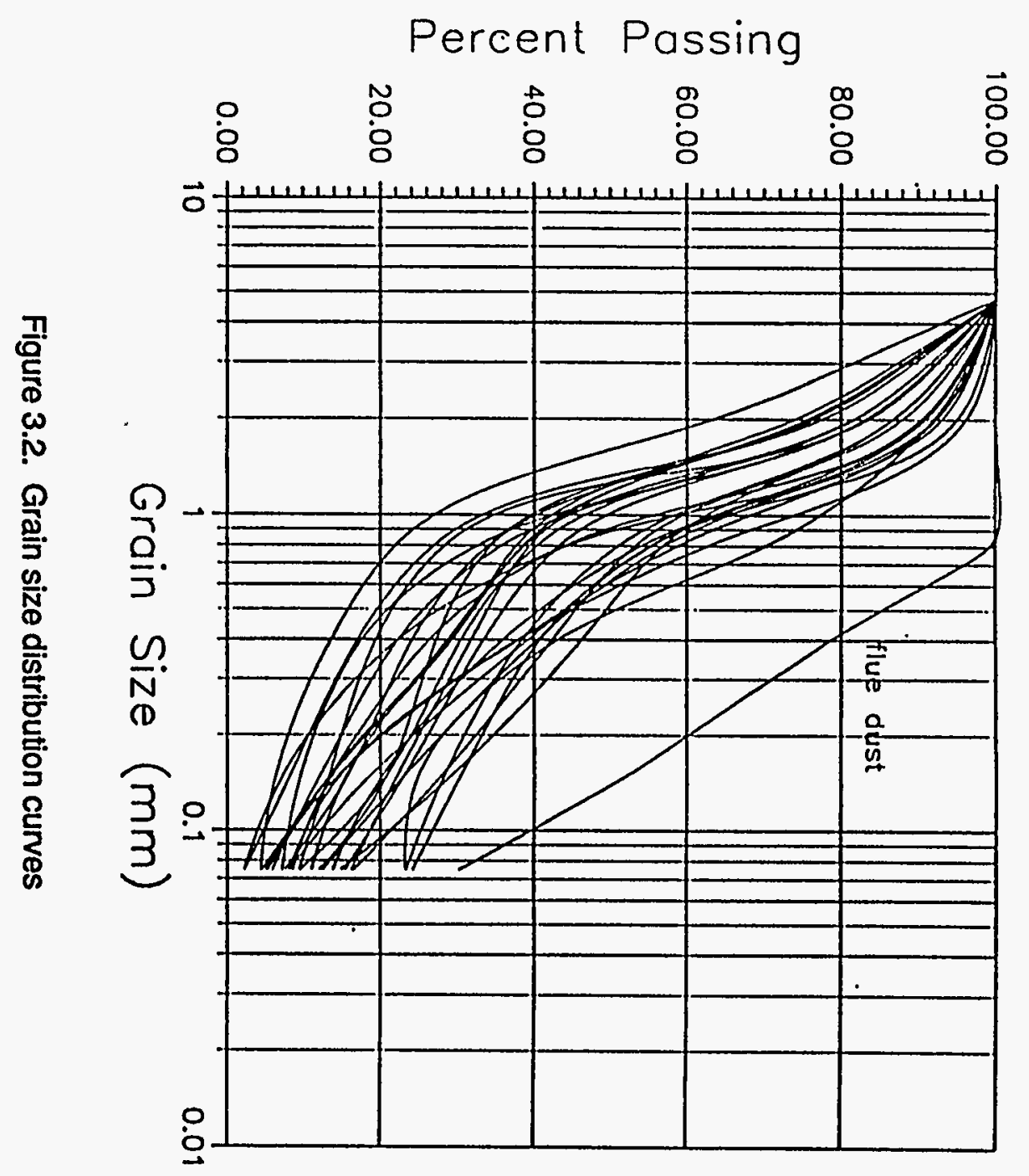


SW: well-graded sands, little or no fines

SP: poorly-graded sands, little or no fines

SM: silty sands, sand-silt mixtures

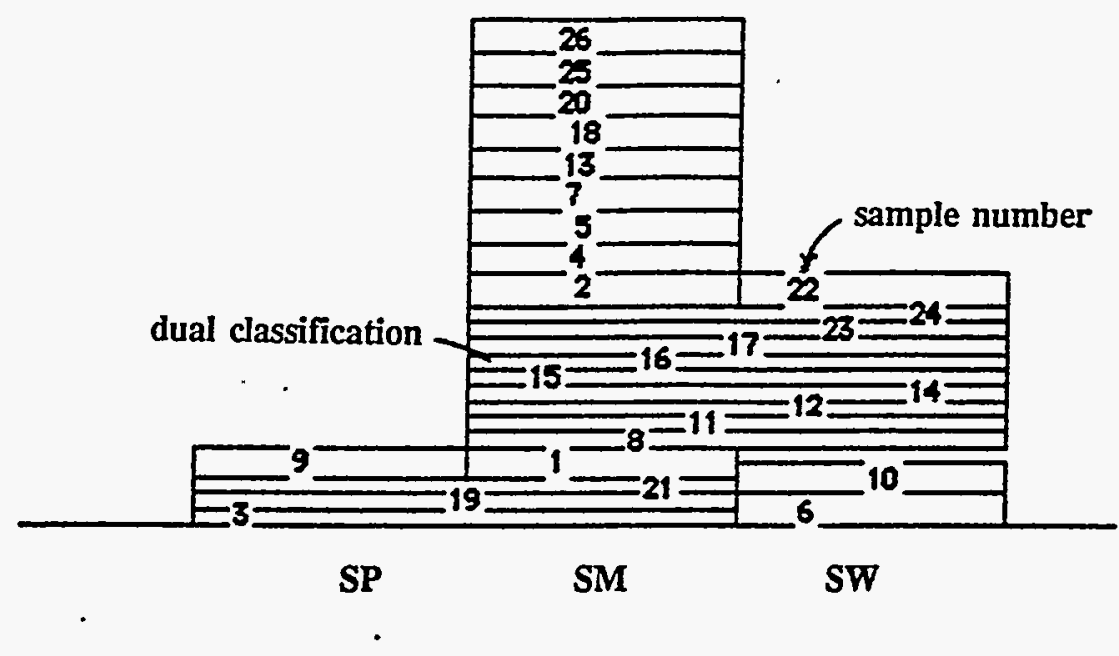

Figure 3.3. Soil classification of surge bin solids 


\subsubsection{Moisture-Density Relationships}

Compaction tests were conducted according to ASTM D698-78 to determine the moisturedensity relationships. This test yields the maximum dry density and corresponding water content ("optimum" water content) that are used to specify placement procedures for waste embankments. Three tests were conducted with seven data points for each test. There was little variation between the three tests and Figure 3.4 shows the curve of dry density versus water content with all twentyone data points. The optimum water content is 27 percent and the maximum dry density is 14.7 $\mathrm{kN} / \mathrm{m}^{3}$.

\subsubsection{Shear Strength}

Shear strength is the most important soil property required for evaluating the stability of processed shale disposal embankments. Shear strength is not a unique soil parameter and depends upon the loading conditions, water content, effective overburden stress, and stress history of the soil. During the construction phase of an embankment, undrained or short-term loading conditions are critical and the undrained strength is used to evaluate embankment stability. The appropriate strength parameters are the undrained angle of friction ( $\phi)$ and undrained cohesion (c) as determined in a consolidated undrained (CU) triaxial test, or the unconfined compressive strength $\left(q_{u}\right)$. Following construction, when the final geometry and overburden stresses have been established, the long-term strength properties are applicable. These include the drained or effective stress angle of friction $\left(\phi_{D}^{\prime}\right)$, and the drained or effective stress cohesion ( $\left.c^{\prime}\right)$, as determined from a consolidated drained (CD) triaxial test.

Censolidated-Drained Triaxial Tests. Twenty-five specimens of spent shale were prepared and tested in CD triaxial tests at confining stresses ranging from $48 \mathrm{kN} / \mathrm{m}^{2}$ to $10,345 \mathrm{kN} / \mathrm{m}^{2}(7 \mathrm{psi}$ to 1500 psi). All specimens were prepared at an initial water content of 15 percent and compacted to an average dry density of $14.0 \mathrm{kN} / \mathrm{m}^{3}$, consolidated to cell pressure, and loaded to failure in triaxial 


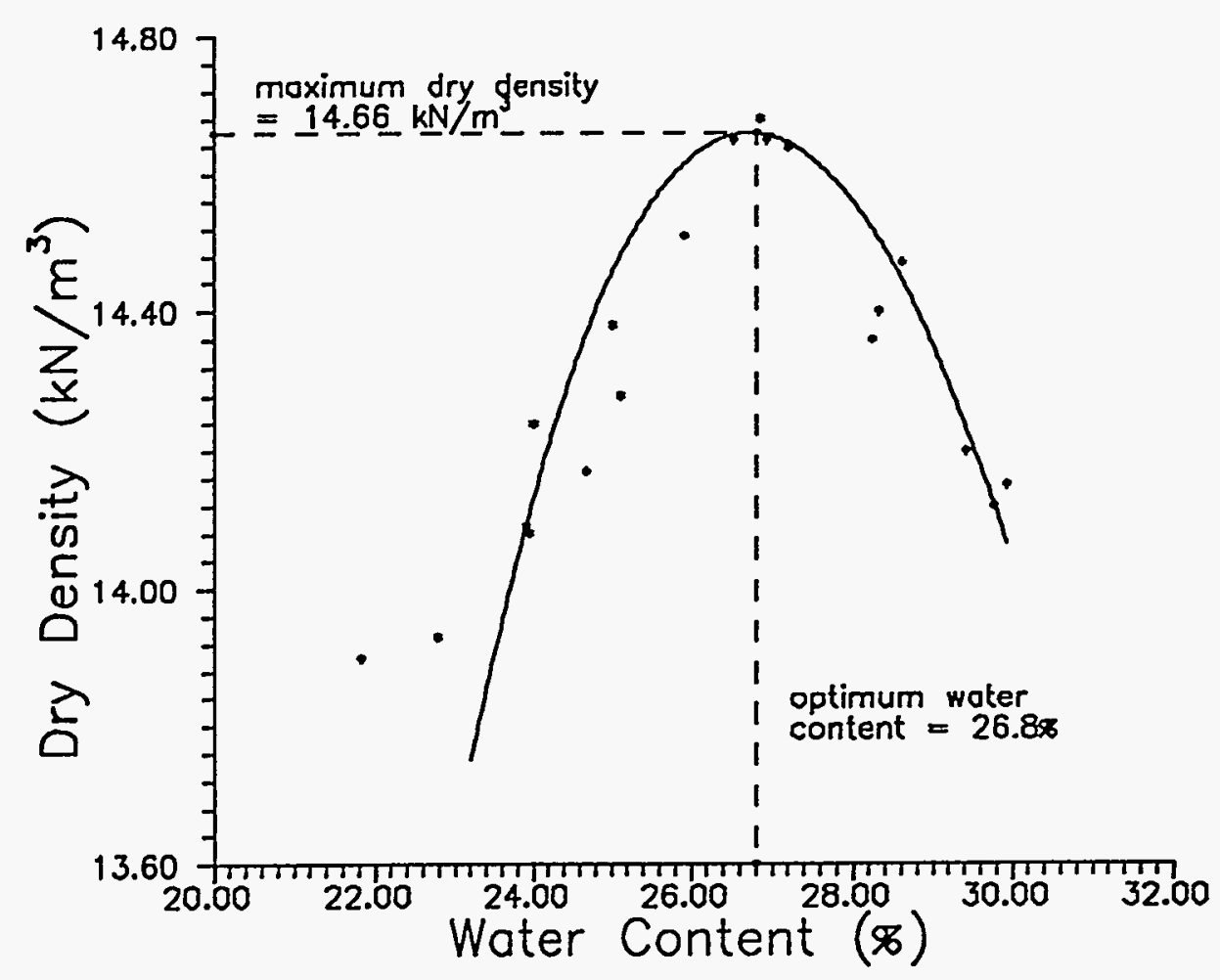

Figure 3.4. Moisture-density relationship for Lurgi spent shale 
compression. Nineteen of the specimens were tested in a triaxial cell capable of confining stresses up to $580 \mathrm{kN}^{2}$ (84psi) and six specimens were tested in a high pressure cell capable of applying confining stresses up to $10,345 \mathrm{kN} / \mathrm{m}^{2}$ (1500 psi).

The results of the first nineteen tests with confining stresses up to $580 \mathrm{KN} / \mathrm{m}^{2}$ are plotted in Mohr-Coulomb stress space in Figure 3.5(a). The failure envelope is approximately linear over this range of confining stresses and is characterized by an effective stress angle of friction of 37.9 degrees and an effective stress cohesion of $11.9 \mathrm{kN} / \mathrm{m}^{2}$. The failure envelope for the high confining stress tests is plotted in Figure 3.5(b) and yields a friction angle of 34 degrees and a cohesion of $165.5 \mathrm{kN} / \mathrm{m}^{2}$. This indicates that the failure envelope exhibits curvature at higher confining stresses. Curvature of the failure envelope should be incorporated into stability analyses by decreasing the friction angle with increasing overburden stress. For example, the friction angle can be decreased by one degree (from its initial value of 38 degrees) for each $2,000 \mathrm{kN} / \mathrm{m}^{2}$ overburden stress. The overburden stresses at the bottom of a $300 \mathrm{~m}$ high waste embankment would be in the range of $5,000 \mathrm{kN} / \mathrm{m}^{2}$.

Consolidated-Undrained Triaxial Tests. Fifteen CU triaxial tests were conducted on specimens of processed shale prepared at an initial water content of 15 percent and a dry density of $14.0 \mathrm{kN} / \mathrm{m}^{3}$. Confining stresses ranged from $51.7 \mathrm{kN} / \mathrm{m}^{2}$ to $469 \mathrm{kN} / \mathrm{m}^{2}$. The results are plotted on a Mohr-Coulomb diagram in Figure 3.6 and yield an undrained friction angle of 14.4 degrees and undrained cohesion of $162.0 \mathrm{kN} / \mathrm{m}^{2}$.

Uncenfined Compression Tests. The unconfined compression tests were designed to evaluate the effects of cementation on the strength of combusted Lurgi-processed shale. Specimens were prepared at four different initial water contents $(15,20,25$, and 30 percent), allowed to cure for four different time periods $(1,7,14$, and 28 days), and then tested in unconfined compression. During the curing period, the specimens were wrapped in cellophane to minimize the 


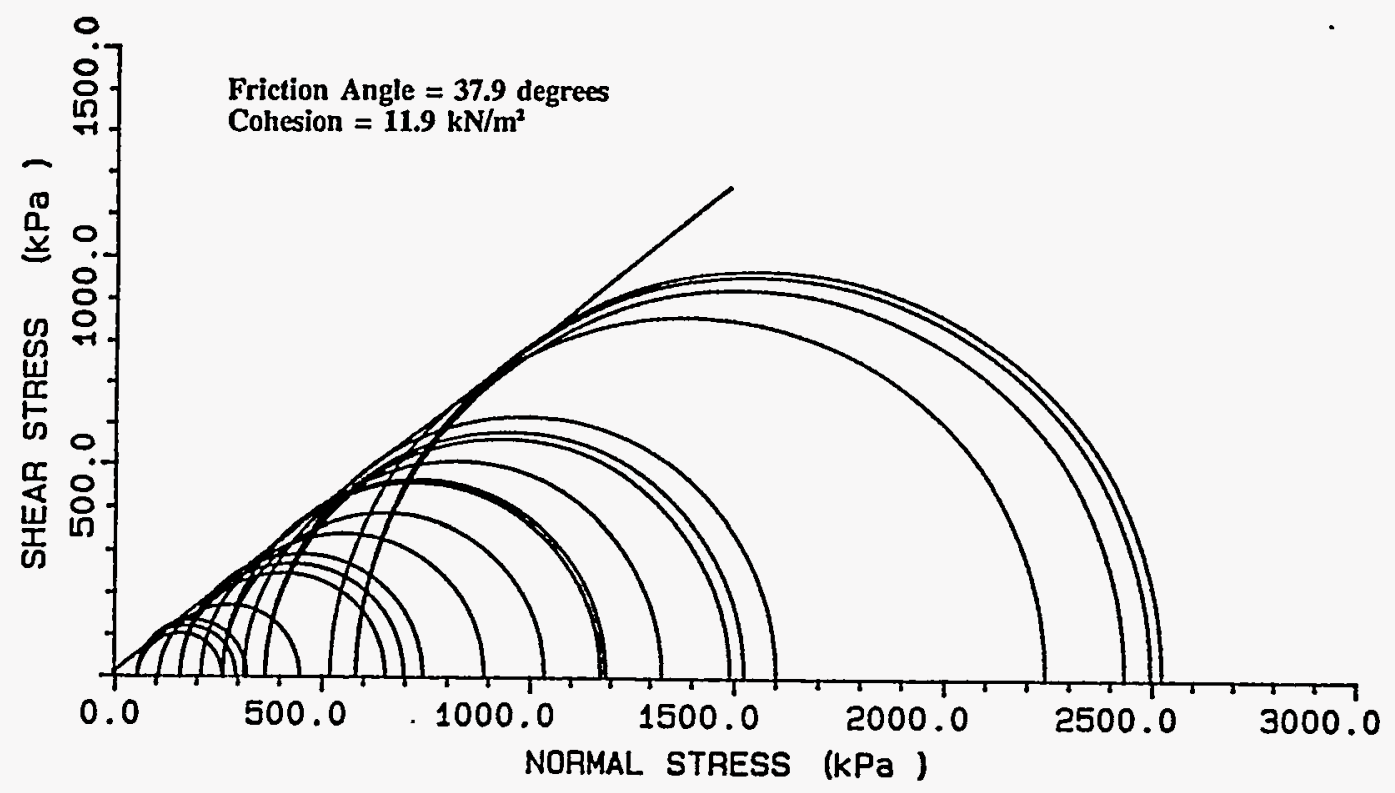

a. Confining stress up to $580 \mathrm{kN} / \mathrm{m}^{2}$

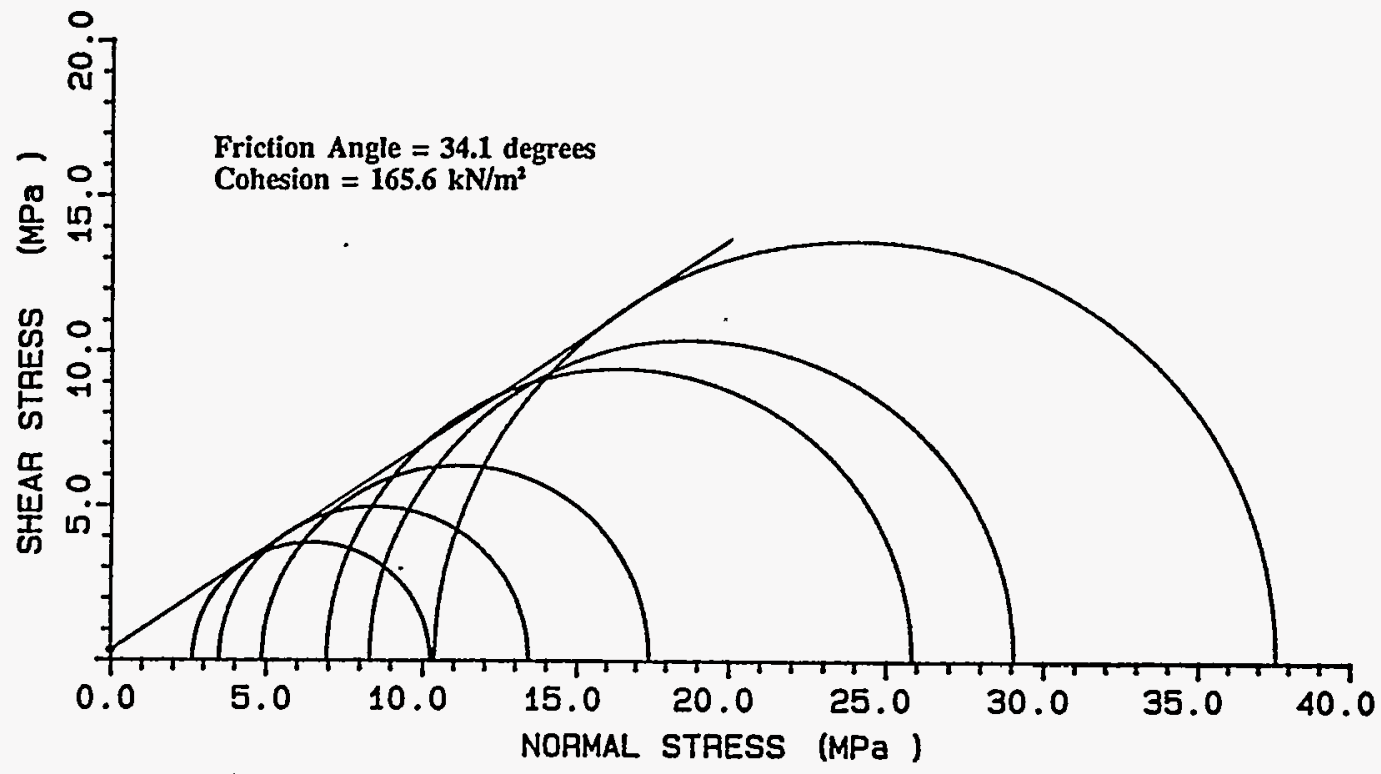

b. Confining stress up to $10.3 \mathrm{MN} / \mathrm{m}^{2}$

Figure 3.5. Mohr-Coulomb failure envelopes from CD triaxial tests 


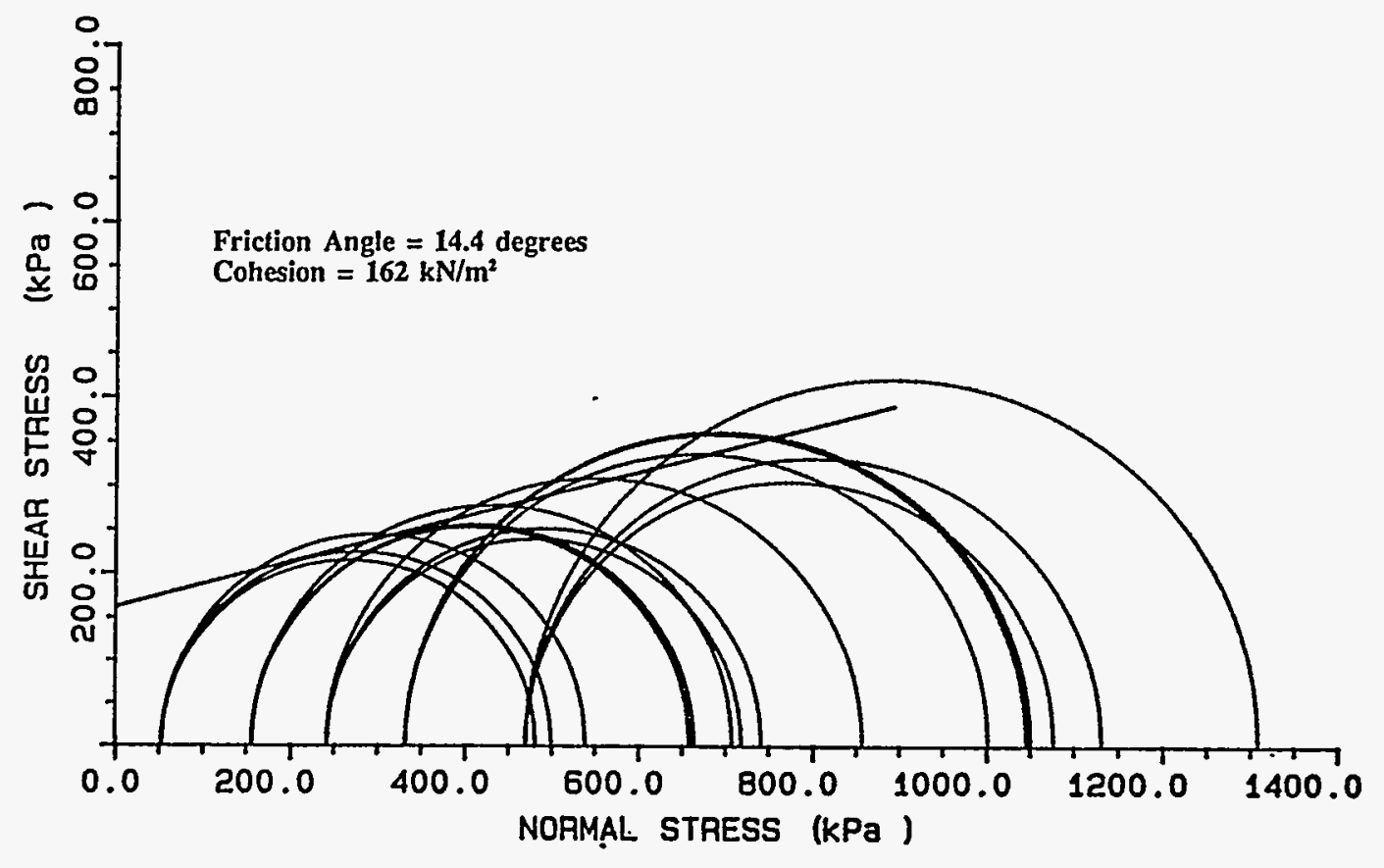

Figure 3.6. Mohr-Coulomb failure envelope from CU triaxial tests 
loss of moisture by evaporation. Three specimens were prepared and tested for each of the sixteen combinations of water content and curing time.

Curves of unconfined compressive strength $\left(q_{u}\right)$ versus curing time for each initial water content are presented in Figure 3.7. Each curve is a second order polynomial best fit. The results show an increase in $q_{w}$ with increasing curing time and with increasing initial water content. At initial water contents of 25 and 30 percent, $q_{u}$ apparently would increase even beyond the 28 day period.

\subsubsection{Hydraulic Conductivity}

The movement of water through a processed shale waste embankment is the primary factor controlling the release of potentially harmful leachates into surface and groundwater. The hydraulic conductivity $(k)$ of the processed shale is required to predict the flux and velocity of water. The hydraulic conductivity of compacted soils is influenced by a number of factors including molding water content, degree of saturation, compactive effort, void ratio, chemistry of the permeant liquid, age of the soil, and others (Boynton and Daniel 1985). Samples of Lurgi spent shale were tested using the triaxial falling head permeability method to evaluate the influence of compacted density on hydraulic conductivity. In addition, the results of tests conducted by Sri Ranjan and others (1989) were used to evaluate the variation of hydraulic conductivity with water content for Lurgi spent shale.

To evaluate the influence of compactive effort, thirty-five specimens of the spent shale were mixed at molding water contents ranging from 15 to 30 percent (by weight) to achieve dry densities ranging from $12.5 \mathrm{kN} / \mathrm{m}^{3}$ to $14.4 \mathrm{kN} / \mathrm{m}^{3}$, allowed to cure for one day at room temperature and humidity, placed in a triaxial cell under a confining stress of $48.3 \mathrm{kN} / \mathrm{m}^{2}$, and tested for falling head permeability. The results are presented in Figure 3.8 and show a significant decrease in hydraulic conductivity with increasing dry density. The overall decrease is over three orders of magnitude, illustrating the importance of appropriate compaction specifications and field quality control in order to control the hydraulic conductivity of the combusted shale in a disposal embankment. 


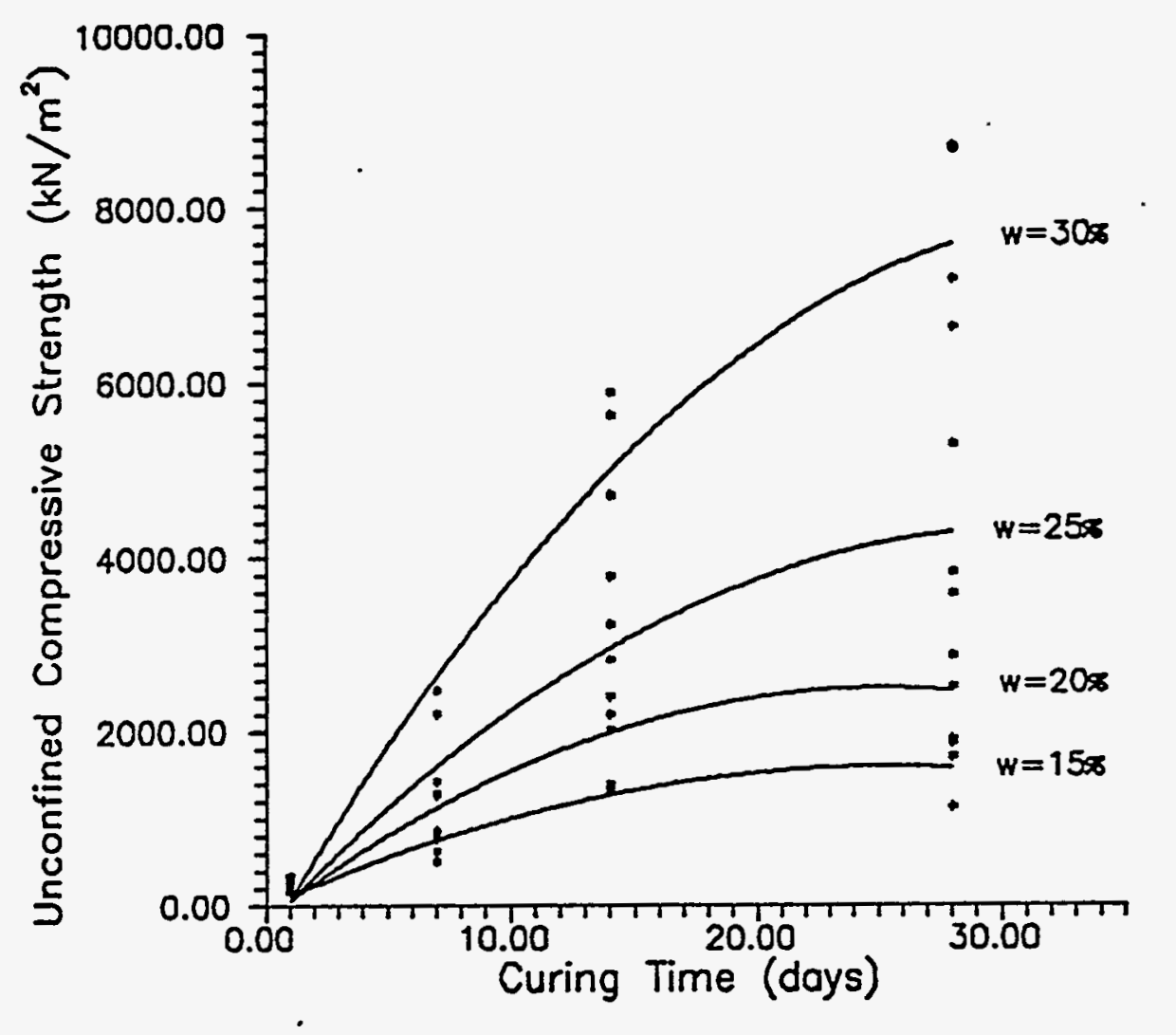

Figure 3.7. Unconfined compressive strength versus curing time

Sri Ranjan and others (1989) evaluated the saturated hydraulic conductivity of Lurgi processed shale as a function of molding water content and time. Specimens mixed at water contents of $0,10,15$, and 20 percent (by weight) and compacted to $14.2 \mathrm{kN} / \mathrm{m}^{3} \mathrm{dry}$ density were cured for 90 days in rubber-sleeved permeameter cells, submerged in water to achieve saturation, and subjected to falling head permeability tests over a 216 day period. The results are presented in Figure 3.9 showing saturated hydraulic conductivity versus time for the four different curing water contents. The specimens prepared and cured at water contents of 10,15, and 20 percent exhibit a much different behavior over time than the specimens that started out dry. Upon saturation, the hydraulic conductivity of the initially dry specimens decreased by three orders of magnitude to approximately $3 \times 10^{-8} \mathrm{~cm} / \mathrm{sec}$ after 216 days. The specimens cured at the other water contents did not exhibit the same decrease in hydraulic conductivity. This observed behavior was explained by Sri Ranjan and others (1989) as an "armoring effect" in which incomplete hydration of the processed 


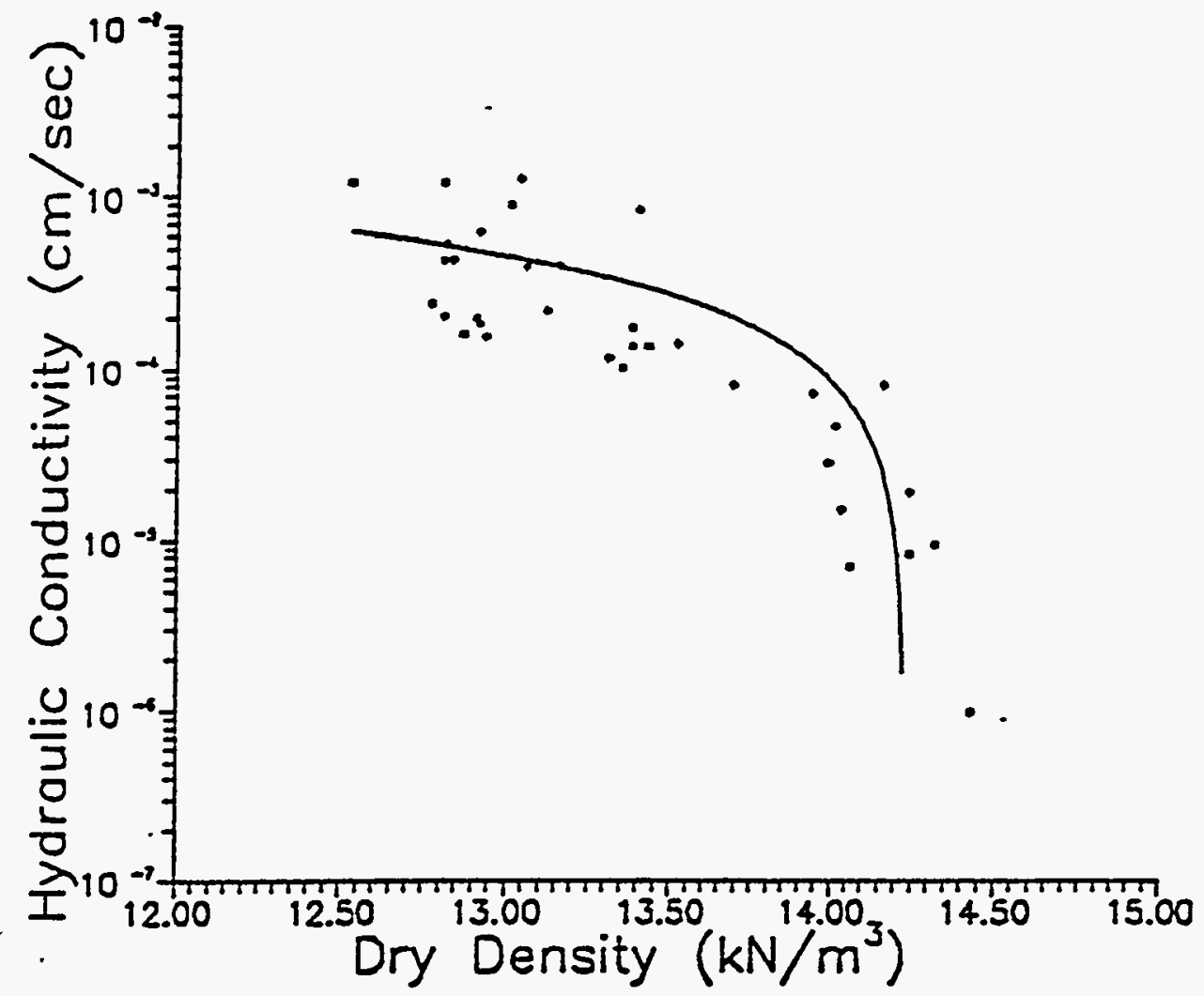

Figure 3.8. Hydraulic conductivity versus dry density 


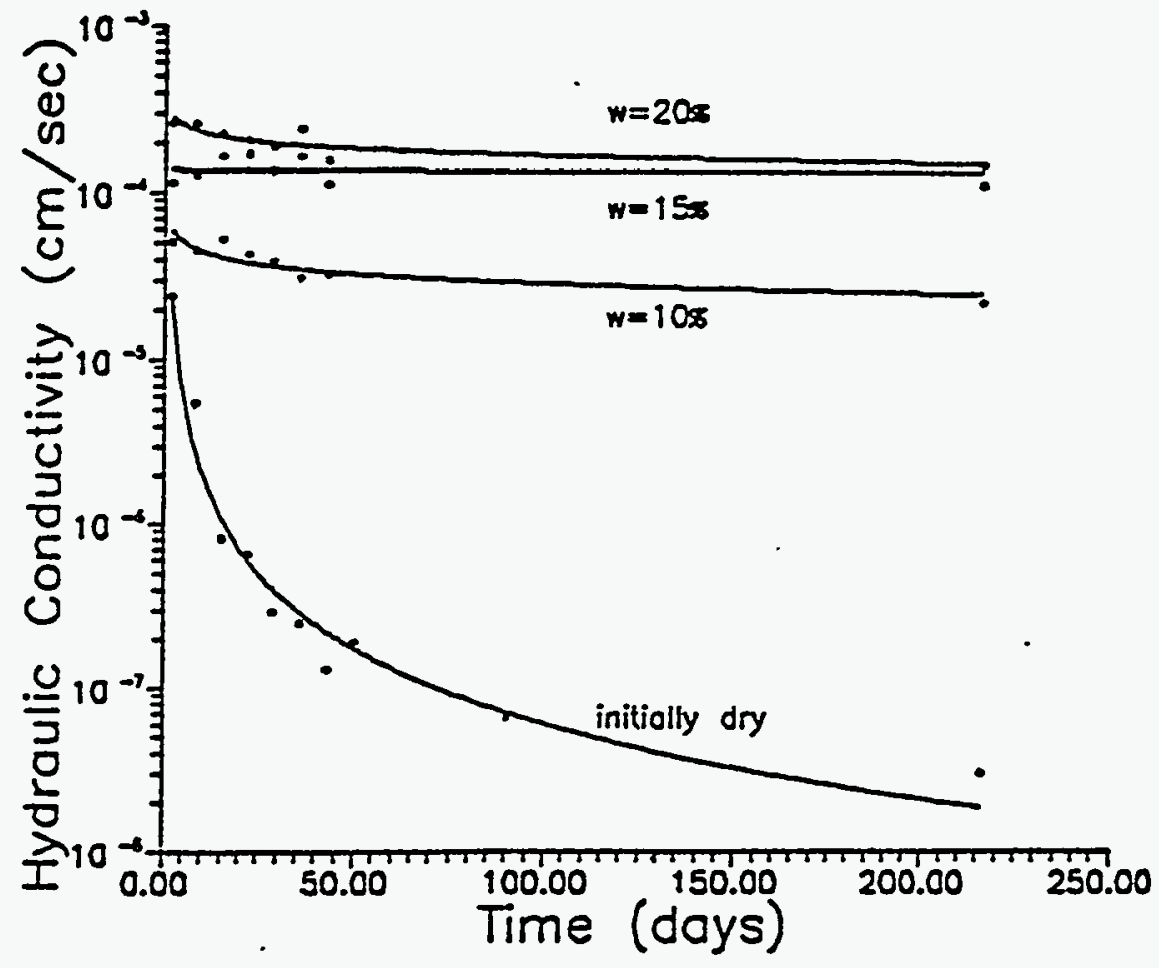

Figure 3.9. Hydraulic conductivity versus time for different curing moisture contents. Data from Sri Ranjan (1989) 
shale causes large pore spaces occupied by air to be "frozen" into place. Subsequent saturation of the material following curing was effectively prevented. In order to achieve complete hydration and a full reduction in hydraulic conductivity the authors suggest an initial degree of saturation of at least 85 percent.

A similar phenomena was observed in this study when mixing Lurgi-processed shale with water in both field and laboratory tests. At water contents below approximately 25 percent (degree of saturation $=85$ percent), a portion of the moist mix consists of relatively large aggregated particles of processed shale (up to $1 \mathrm{~cm}$ in diameter) which are moist on the outside but dry inside. When these aggregated particles are allowed to cure, they consist of a cemented outer shell with dry, unhydrated processed shale inside. The outer shell of these particles can barely be broken between one's fingers. This gives the processed shale the texture of a lightly-cemented coarse sand consisting in part of large aggregated particles cemented on the outside, resulting in a relatively high hydraulic conductivity. If the same material is cured at a water content sufficient to allow complete hydration, the entire mass becomes highly cemented, the large aggregated particles do not form, and the material becomes practically impermeable. This observation and those of Sri Ranjan et al. (1989) demonstrate that cementation is the most significant factor affecting the hydraulic conductivity of laboratory prepared specimens of combusted Western oil shale.

For this study, a second group of specimens was prepared using soil-cement molds ( $2.8 \mathrm{in}$. dia., 5.6 in. high) to evaluate the effects of initial water content and curing time on hydraulic conductivity. The results are presented in Figure 3.10, which shows exponential best fit curves of the data for $k_{\text {sat }}$ versus curing time, for water contents of 15, 20, 25, and 27 percent. As can be seen, the scatter is large and there is no apparent trend of correlation with either water content or curing time. There is a subtle suggestion that $k_{\text {sat }}$ converges to a value between $10^{-5}$ and $10^{-4}$ $\mathrm{cm} / \mathrm{sec}$, however the trend is not significant enough to warrant a conclusion on this basis. Further testing may be needed to discern the effects of initial water content and curing time. 


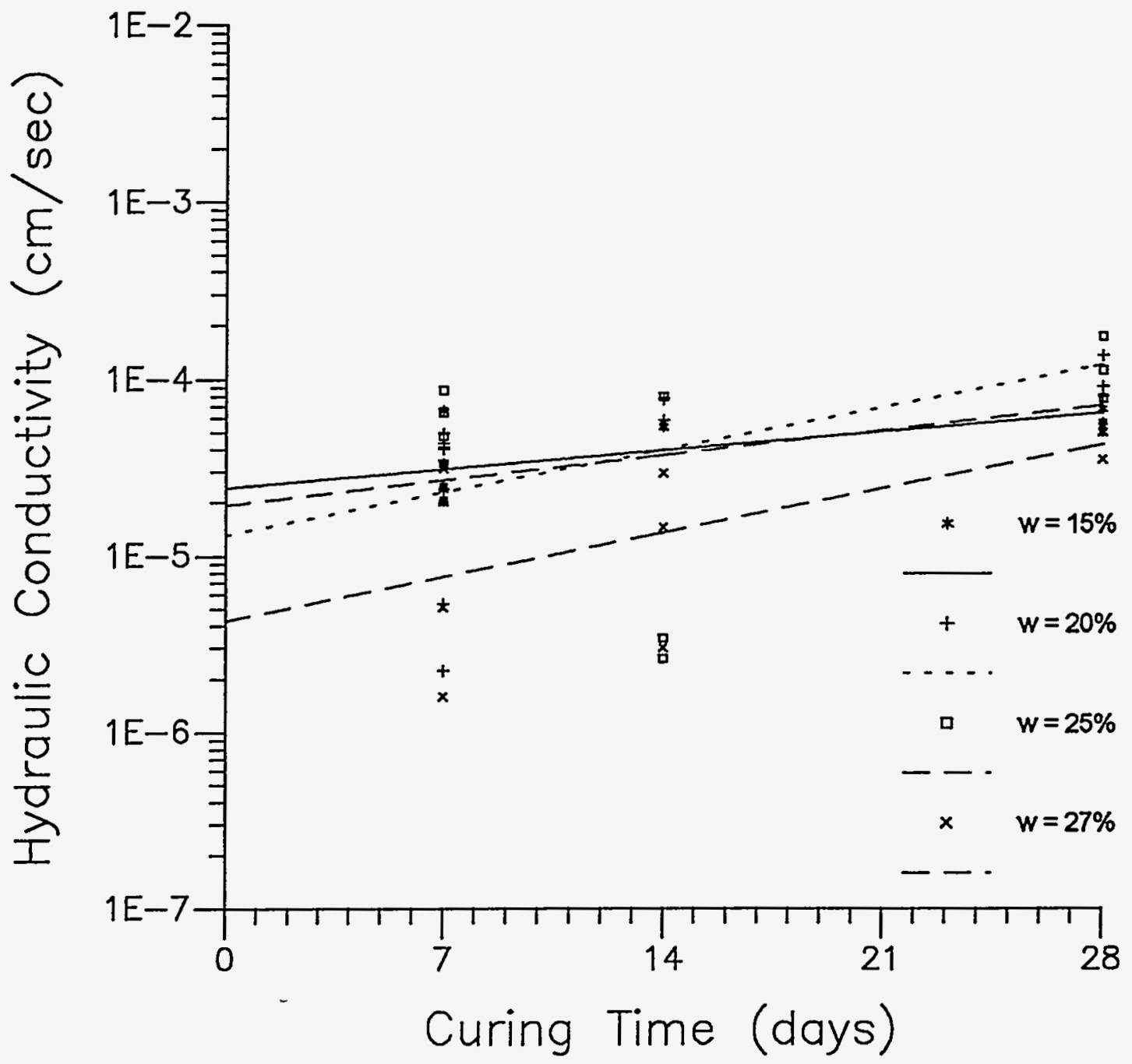

Figure 3.10. Hydraulic conductivity versus curing time for specimens prepared at four different water contents 


\subsubsection{Effects of Weathering}

A total of thirty pairs of specimens were subjected to artificial weathering by wet-dry or freeze-thaw conditions. All specimens withstood twelve cycles without failure. Tables 3.3 and 3.4 present the maximum volume change, maximum water content during testing, percent water retained following the final oven drying, and cement loss (as a percentage of total initial specimen weight) for each pair of specimens. As a comparison, for highway subgrade construction, cement-stabilized soils are required to withstand twelve cycles with a maximum cement loss of $14 \%$. All cement losses for the processed shale were well below $14 \%$. Note that the percent water retained is in the range of 3-5\%, approximately the percentage of water believed to be bound up by cementation.

Effects on Strength. Following a 28-day curing period, 24 days of weathering, and two saturated hydraulic conductivity tests, one specimen from each pair was subjected to a CU triaxial compression test. The resulting total stress Mohr's circles at failure are plotted in Figure 3.11. The weathered specimens show considerably higher strengths than the unweathered specimens (Figure 3.6) and the results fall into two groupings. The first group consists of the specimens prepared at a water content of $w=15 \%$ and exhibits lower strengths than the second group, prepared and cured at a water content of $w=27 \%$. Apparently, the angle of friction does not change, but the cohesion changes significantly, possibly because of cementation. The differences in strength between the weathered and unweathered specimens and between the weathered specimens at $w=15 \%$ versus $w=27 \%$ can be explained by the effects of specimen preparation and curing on cementation. The unweathered specimens were cured for seven days and then tested in triaxial compression tests. The weathered specimens were cured for twenty-eight days, during which time they may have gained significantly higher strengths from cementation, with the specimens $w=27 \%$ developing considerably more cementitious bonding than those at $w=15 \%$. 
Table 3.3. Weathering Results, Soil Cement Specimens at $w=15$ percent.

\begin{tabular}{|c|c|c|c|c|c|c|c|}
\hline Specimen & Dry Density & Cure Time & W-D or & Max. Vol. & Maximum & Water & Soil Cement \\
\hline Number & (pci) & (weeks) & F-TH & Change (\%) & $w(\%)$ & Retained (\%) & Loss $(\%)$ \\
\hline M90-29 & 87.8 & 4 & W-D & -0.4 & 37.1 & 4.6 & \\
\hline $\mathrm{M} 90-30$ & 87.7 & 4 & $W-D$ & & & & 0.7 \\
\hline J90-13 & 88 & 4 & W-D & -1 & 37.1 & 3.9 & \\
\hline J90-14 & 88.1 & 4 & $W-D$ & & & & 3.8 \\
\hline JU90-14 & 87.9 & 4 & $W-D$ & 0.55 & 35.4 & 3.9 & \\
\hline JU90-15 & 88.1 & 4 & W-D & & & & 4 \\
\hline M90-27 & 87.7 & 4 & F-TH & 4.4 & 39.4 & 4.2 & \\
\hline M90-28 & 87.9 & 4 & F-TH & & & & 4 \\
\hline J90-15 & 88.1 & 4 & F-TH & 3.9 & 38.7 & 3.9 & \\
\hline$\sqrt{90-16}$ & 88 & 4 & F-TH & & & & 2.4 \\
\hline JU90-16 & 88 & 4 & F-TH & 2.5 & 38.7 & 3.9 & \\
\hline JU90-17 & 88.1 & 4 & F-TH & & & & 0.8 \\
\hline JU90-27 & 88.1 & 4 & W-D & 0.64 & 36.9 & 4 & \\
\hline JU90-28 & 87.9 & 4 & $W-D$ & & & & 3.4 \\
\hline $190-17$ & 87.9 & 4 & W-D & -0.6 & 36.9 & 3.9 & \\
\hline J90-18 & 88.1 & 4 & W-D & & & & 4.5 \\
\hline JU90-3 & 88 & 4 & W-D & 0.46 & 35.8 & 3.9 & \\
\hline JU90-4 & 87.9 & 4 & W-D & & & & 4.5 \\
\hline JU90-1 & 88 & 4 & F-TH & 0.57 & 38.5 & 2.7 & \\
\hline JU90-2 & 88 & 4 & F-TH & & & & 3.9 \\
\hline JU90-29 & 87.9 & 4 & F-TH & 4.6 & 36.8 & 2.8 & \\
\hline JU90-30 & 88.2 & 4 & $\mathrm{~F}-\mathrm{TH}$ & & & & 3.2 \\
\hline J90-19 & 88 & 4 & F-TH & 2.5 & 38.5 & 4.6 & \\
\hline J90-20 & 88.1 & 4 & F-TH & & & & 3.7 \\
\hline JU90-10 & 87.9 & 4 & W-D & 0.44 & 35.4 & 3.9 & \\
\hline JU90-11 & 87.8 & 4 & W-D & & & & 3.8 \\
\hline J90-5 & 88.1 & 4 & $W-D$ & 0.57 & 36.7 & 3.9 & \\
\hline J90-6 & 88 & 4 & W-D & & & & 3.8 \\
\hline AU90-1 & 88 & 4 & $W-D$ & -0.44 & 36.7 & 4.7 & \\
\hline AU90-2 & 88.1 & 4 & $W-D$ & & & & 4.7 \\
\hline JU90-12 & 88.3 & 4 & F-TH & 2 & 37.9 & 4.2 & \\
\hline JU90-13 & 88.1 & 4 & F-TH & & & & 4.7 \\
\hline $\mathrm{J} 90-7$ & 88.1 & 4 & F-TH & 2.6 & 37.4 & 4.3 & \\
\hline $\mathrm{J} 90-8$ & 88 & 4 & F-TH & & & & 3.8 \\
\hline AU90-3 & 88 & 4 & F-TH & 1.6 & 38.3 & 4.6 & \\
\hline AU90-4 & 88 & 4 & F-TH & & & & 4.1 \\
\hline
\end{tabular}


Table 3.4. Weathering Results, Soil-Cement Specimens at $w=27$ percent.

\begin{tabular}{|l|c|c|c|c|c|c|c|}
\hline Specimen & Dry Density & Cure Time & W-D or & Max. Vol. & Maximum & Water & Soil Cement \\
\hline Number & (pcf) & (weeks) & F-TH & Change (\%) & w (\%) & Retained (\%) & Loss (\%) \\
\hline & & & & & & & \\
\hline M90-14 & 93 & 4 & W-D & -0.88 & 31.6 & 4.1 & \\
\hline M90-15 & 93.1 & 4 & W-D & & & & 4.2 \\
\hline JU90-23 & 93.5 & 4 & W-D & -0.85 & 31.3 & 4 & \\
\hline JU90-24 & 93 & 4 & W-D & & & & 4.3 \\
\hline JU90-25 & 93.1 & 4 & F-TH & -0.35 & 31.7 & 4.1 & \\
\hline JU90-26 & 93.4 & 4 & F-TH & & & & 4.3 \\
\hline M90-12 & 93 & 4 & F-TH & 1.2 & 31.6 & 4.1 & \\
\hline M90-13 & 93 & 4 & F-TH & & & & 4.2 \\
\hline M90-35 & 93.2 & 4 & W-D & -0.85 & 30.3 & 4.1 & \\
\hline M90-36 & 93.3 & 4 & W-D & & & & 3.8 \\
\hline JU90-35 & 93.3 & 4 & W-D & 0.42 & 31.3 & 4.1 & \\
\hline JU90-36 & 93.4 & 4 & W-D & & & & 3.8 \\
\hline M90-33 & 93.1 & 4 & F-TH & 0.5 & 31.5 & 4.1 & \\
\hline M90-34 & 93 & 4 & F-TH & & & & 3.8 \\
\hline JU90-33 & 93.5 & 4 & F-TH & -0.28 & 32.5 & 3.7 & \\
\hline JU90-34 & 93.7 & 4 & F-TH & & & & 4.4 \\
\hline JU90-6 & 93.1 & 4 & W-D & -1.2 & 31.2 & 4.1 & \\
\hline JU90-7 & 93.3 & 4 & W-D & & & & 3.7 \\
\hline J90-9 & 93.4 & 4 & W-D & -0.75 & 30.9 & 4.1 & \\
\hline J90-10 & 93 & 4 & W-D & & & & 3.8 \\
\hline$J U 90-8$ & 93.3 & 4 & F-TH & -0.36 & 32.1 & 4 & \\
\hline JU90-9 & 93 & 4 & F-TH & & & & 3.9 \\
\hline J90-11 & 93.4 & 4 & F-TH & -0.46 & 32.2 & 4.1 & \\
\hline$J 90-12$ & 93.2 & 4 & F-TH & & & & 3.8 \\
\hline JA90-2 & 95.1 & 1 & W-D & 3.3 & 27.9 & 3.5 & \\
\hline JA90-3 & 93.7 & 1 & W-D & & & & 3.9 \\
\hline JA90-5 & 92.6 & 1 & F-TH & 4.7 & 33.4 & 3.7 & \\
\hline JA90-4 & 92.8 & 1 & F-TH & & & & 3.8 \\
\hline
\end{tabular}




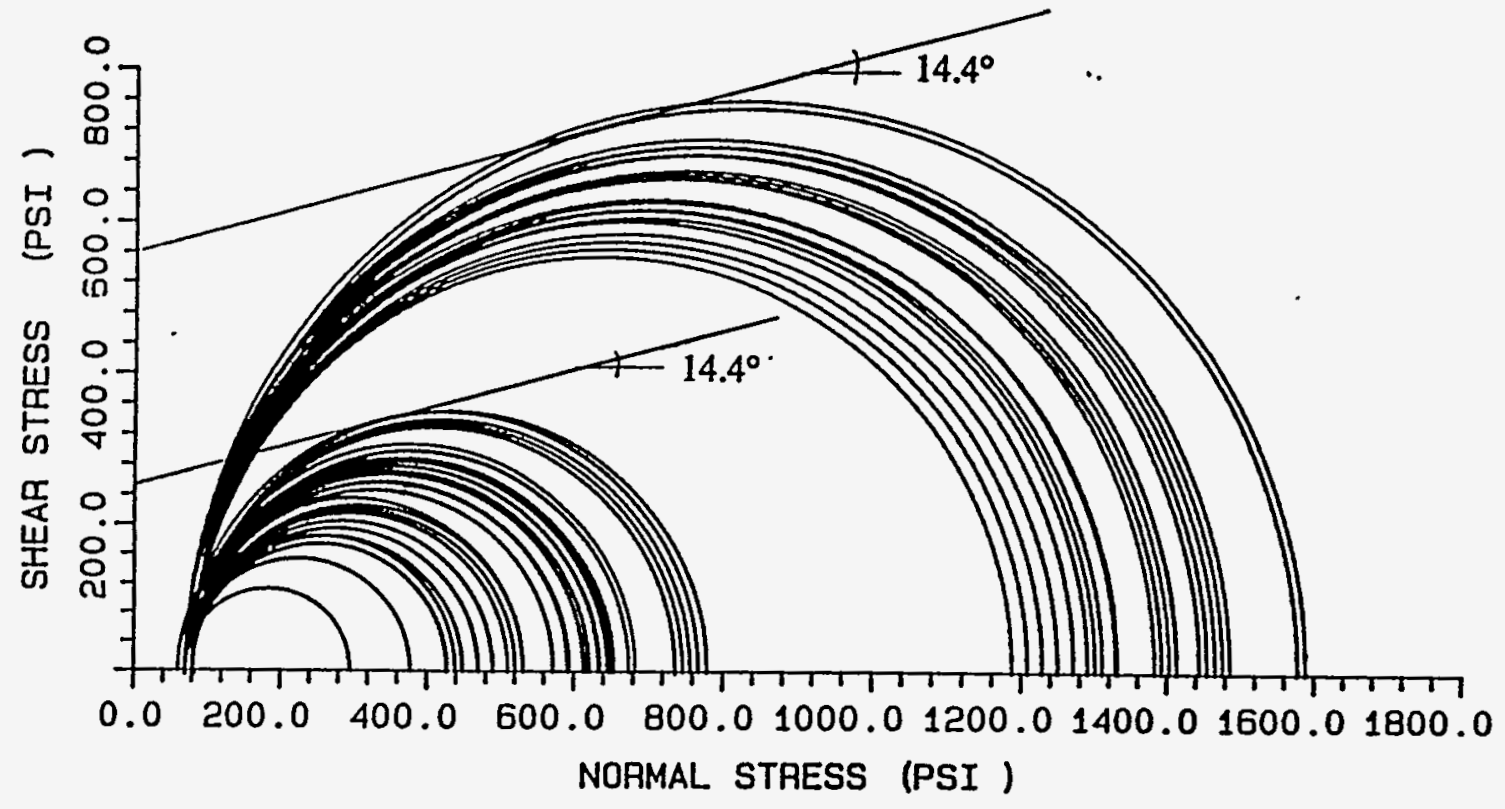

Figure 3.11. Results of consolidated undrained(CU) triaxial tests on weathered spent shale 
If it is assumed that the undrained friction angle does not change from 14.4 degrees measured on the unweathered specimens (Figure 3.6), then the increased cohesion resulting from longer curing times and different water contents of the weathered specimens can be seen in Figure 3.11.

Effects on Hydraulic Conductivity. A series of tests were conducted to determine the hydraulic conductivity of hydrated spent shale as a function of mixing water content, water content during flow, and weathering. Four groups of specimens were prepared and tested for hydraulic conductivity using a flow pump permeameter. The first set of specimens was mixed and compacted at a water content of 15 percent, allowed to cure for seven weeks under constant temperature and humidity, then tested for hydraulic conductivity at varying degrees of saturation. A second set of specimens was prepared under the same conditions, but after a three-week curing period specimens were subjected to either freeze-thaw or wet-dry conditions in accordance with ASTM D 559-82 (Standard Method for Wetting-Drying Tests of Compacted Soil-Cement Mixtures) or ASTM D 560-82 (Standard Method for Freezing-and-Thawing Tests of Compacted Soil-Cement Mixtures). This artificial weathering lasted four weeks, giving a total time period of seven weeks between specimen preparation and hydraulic conductivity testing. Preparation and testing of the third and fourth sets of specimens were identical to the first and second sets, except that the initial mixing water content was 30 percent.

Results are shown in Figure 3.12 with best fit curves for each set. Hydraulic conductivity decreased significantly by increasing the initial water content from 15 to 30 percent. This is believed to be caused by increased cementation with increasing initial water content. Formation of cementitious compounds fills the pore spaces between particles, reducing conductivity. The overall effect of weathering is to cause a slight increase in hydraulic conductivity compared to unweathered specimens, possibly due to breakdown or destruction of cementitious bonding, or possibly due to formation of microcracks. The effect of degree of saturation can be seen as hydraulic conductivity increases with increasing water content during flow. This behavior is consistent with most porous 


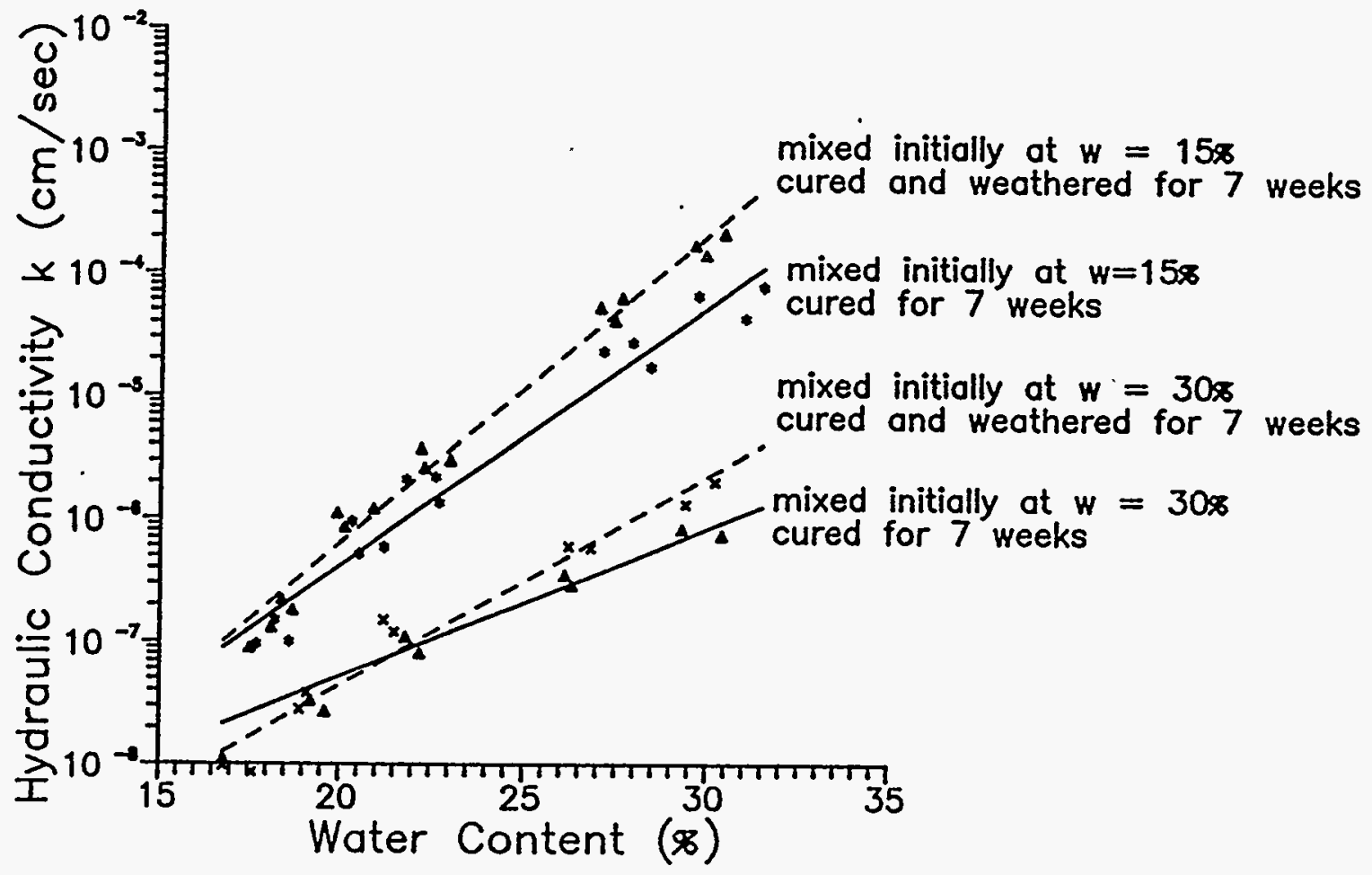

Figure 3.12. Measured hydraulic conductivity as a function of water content and weathering 
media and must be accounted for in numerical or analytical modeling of partially saturated flow. In summary, the most important variables affecting the hydraulic conductivity of bench-scale specimens are mixing water content and water content during flow. The effect of artificial weathering is secondary compared to the effects of water content.

\subsubsection{Soil Moisture Characteristic Curves}

Two tests were conducted using the 15-bar apparatus. The results were essentially identical from the two tests and are plotted in Figure 3.13. Two additional tests were conducted using the 2bar apparatus and the results are shown in Figure 3.14. Each 2-bar test consisted of one cycle of draining and filling. Figure 3.14 clearly shows hysteresis in the characteristic curves. For a given value of soil suction, moisture content is higher when the spent shale is draining than when it is filling. The soil-moisture curves in Figure 3.14 are used in Section 4 to estimate in situ values of soil suction from measurements of water content, and in Section 5 for modeling unsaturated flow. 


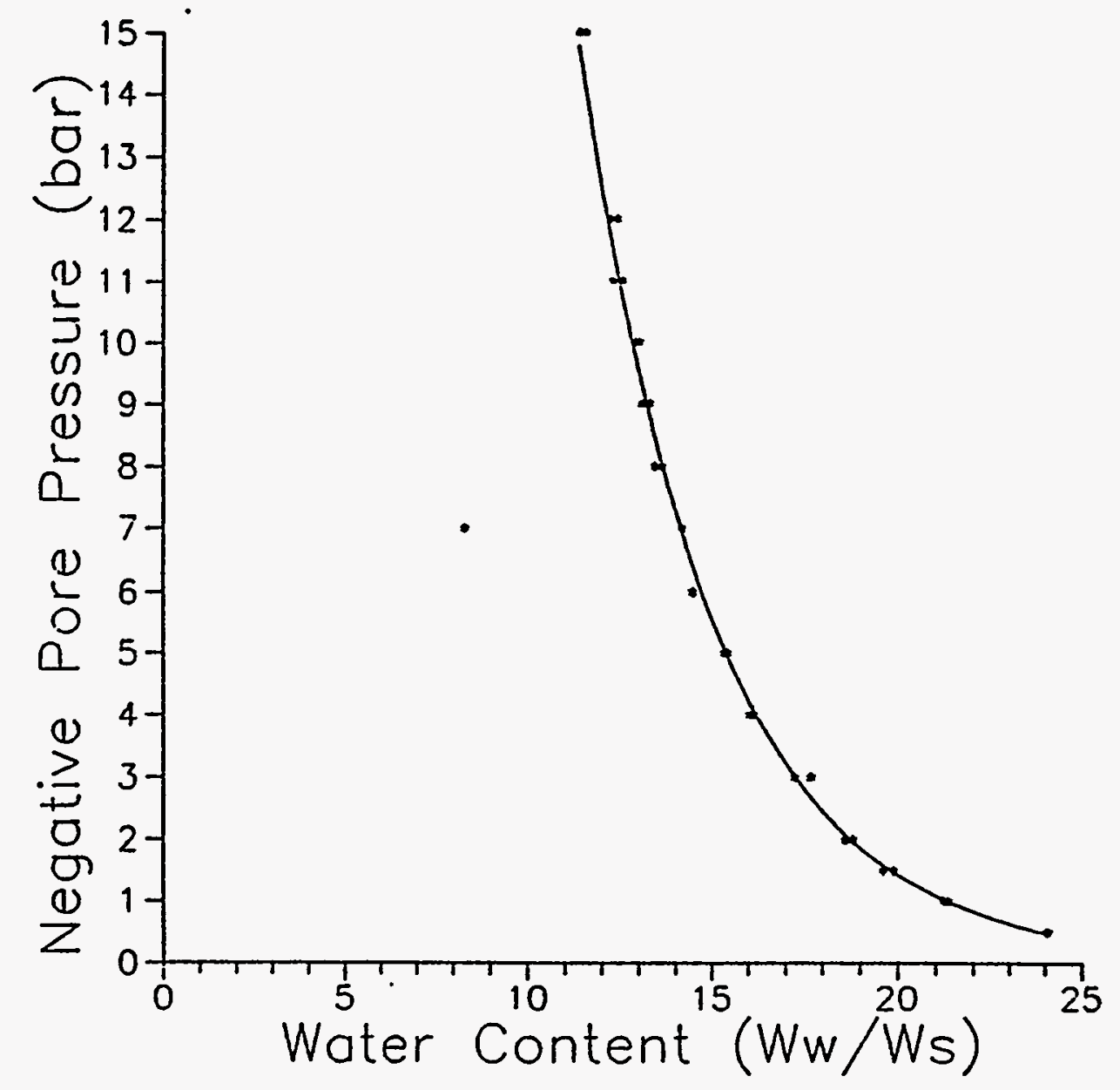

Figure 3.13. Soil moisture characteristic curve for 0 to 15 bars $(0-1,500 \mathrm{kPa})$ 


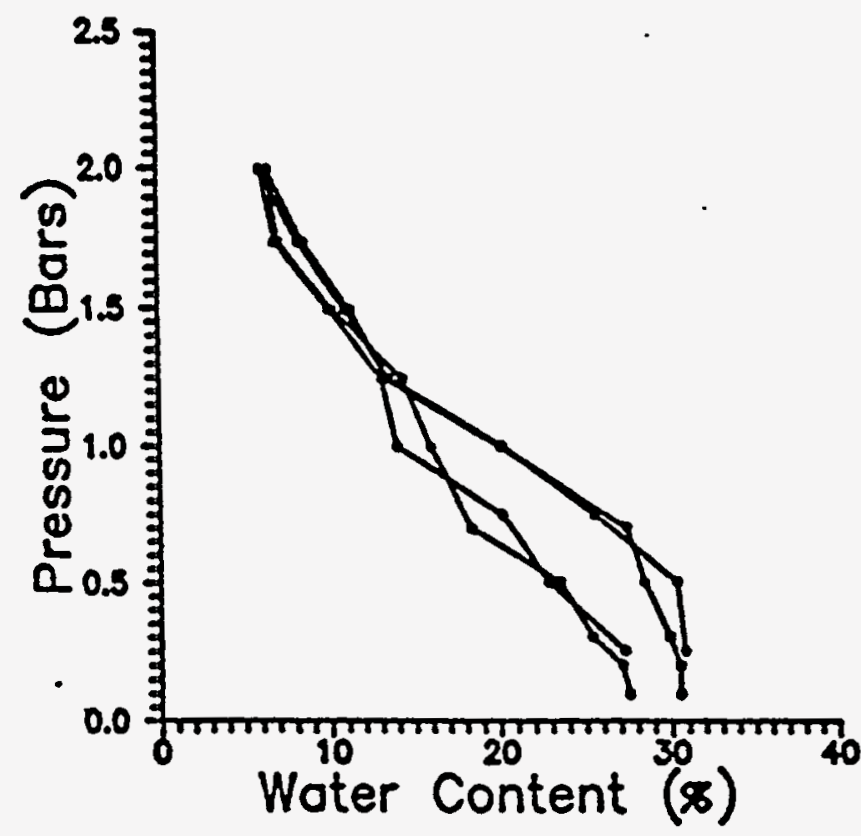

Figure 3.14. Soil-moisture characteristic curves for 0 to 2 bars $(0-200 \mathrm{kPa})$ 


\subsubsection{Discussion on the Effects of Cementation on Geotechnical Properties}

The cementing characteristics of the Lurgi spent shale appear to have a strong influence on its geotechnical properties, especially unconfined compressive strength and hydraulic conductivity. Cementation is a function of the chemical/mineralogical changes that occur when raw oil shale is combusted and then the combusted processed shale is mixed with water.

The inorganic mineral matrix of oil shale from the Green River Formation consists essentially of dolomite, calcite, illite, and quartz, with minor amounts of feldspars, pyrite, and analcime (Prien 1980). Dolomite is calcium magnesium carbonate and calcite is calcium carbonate. When calcium carbonate is heated to combustion temperatures, some loss of $\mathrm{CO}^{2}$ occurs, producing quicklime, $\mathrm{CaO}$. When mixed with water, quicklime forms calcium hydroxide, $\mathrm{Ca}(\mathrm{OH})_{2}$, also referred to as hydrated lime. Hydrated lime reacts with pozzolanic silica and aluminum oxides to form cementitious calcium silicates and calcium aluminates. These compounds are very stable materials that increase in strength with time, and are referred to as hydrous cements (Eglinton 1987). In Green River Formation oil shale, the source of the calcium carbonate for the formation of lime could be calcite and/or dolomite. The pozzolanic silica and aluminum oxides may be derived from the clay mineral illite (aluminum silica) and/or quartz $\left(\mathrm{SiO}_{2}\right)$, and the thermal decomposition of pyrite may yield sulfur.

Culbertson and others (1970), using Green River Formation oil shale combusted at temperatures ranging from 593 to $927^{\circ} \mathrm{C}$ and then hydrated at water contents of 5 to 20 percent, identified tobermorite (a gel of calcium silicate hydrates), low sulfate-sulfoaluminate, and ettringite (high-sulfate tricalcium sulfoaluminate), each of which also is present in hydrated Portland cement (Eglinton 1987). Marcus and others (1985), using Green River Formation oil shale from Piceance Basin combusted at $700^{\circ} \mathrm{C}$, attributed cementation to the growth of crystalline bridges between the processed shale particles. The main mineralogical changes observed during curing at 20 percent water content were the dissolution of anhydrite and hydrolysis of periclase, two minerals present in the combusted shale that are not present in the raw oil shale. The bridging materials were analyzed 
using scanning electron microscope and consisted of calcium and magnesium carbonates or hydroxycarbonates and complex aluminum and silicon compounds of the alkaline earth elements. The formation of these bridging materials appeared to be time-dependent and corresponded to increases in the unconfined compressive strength, similar to those reported in this paper. Marcus and others (1985) reported that the mineral ettringite is not present in hydrated processed shale, in disagreement with the results of Culbertson and others (1970).

As part of a cooperative agreement with the U.S. Department of Energy, Western Research Institute (WRI) conducted a study to evaluate the chemical and mineralogical properties of Lurgi processed shale. The ultimate goal was to relate these properties to engineering properties evaluated by this study, including strength and hydraulic conductivity. Although several technical progress reports were issued by WRI, the results were not sufficient to develop correlations between engineering and chemical/mineralogical properties. The most recent report (Brown and Brown, 1991) concluded:

"The X-ray diffraction data were difficult to interpret because of the amount of amorphous material present in the samples. A positive identification of the material responsible for the increase in cementation over time was not possible. The XRD data show that calcite $\left(\mathrm{CaCO}_{3}\right)$ is a major component of the system and may in some way be responsible for the cementation process. Minor amounts of gypsum may also contribute to the increase in cementing through the formation of ettringite and other minerals."

The chemical/mineralogical changes that occur when raw shale is combusted and then hydrated have not been determined precisely as a function of combustion temperature, molding water content, and curing time, and are not understood completely. Nevertheless, it is apparent from the chemistry and mineralogy of the raw shale and that of the spent shale that the formation of calcium silicates, calcium aluminates, and possibly calcium and magnesium carbonates are 
responsible for cementing, and that the time-dependent formation of the cementing compounds corresponds to time-dependent increases in compressive strength and decreases in hydraulic conductivity. From a waste management point of view, it is desirable to exploit the cementitious properties to design stable and environmentally safe disposal piles.

\subsection{Leachate Chemistry}

\subsubsection{Methods}

A column leaching system was designed and constructed to determine the initial chemical composition and quantity of solubles present from the unweathered Lurgi-processed shale. The system consisted of four columns, each holding a $3.6 \mathrm{~cm}$ diameter by $7.1 \mathrm{~cm}$ high cylindrical specimen. This allowed specimens to be prepared using a Harvard miniature compaction apparatus. This apparatus consists of a cylindrical mold $3.6 \mathrm{~cm}$ in diameter and $7.1 \mathrm{~cm}$ high and a 20-lb springloaded compaction hammer. Each specimen was compacted in five lifts using ten blows per lift. Prepared specimens were held in the apparatus using a flexible wall system. Specimens are enclosed by a flexible latex membrane and placed into the individual chambers of the apparatus. The chambers are pressurized to confine and hold the enclosed specimens. An influent reservoir, containing distilled water, was also pressurized to provide flow through the specimens. Different flow rates (i.e. leaching rates) could be achieved by varying the pressure applied to the influent reservoir.

Two sets of samples, each set consisting of four specimens, were prepared using the Harvard miniature apparatus at water contents of 15 and 20 percent by weight. Following compaction, specimens were extruded from the mold, sealed in plastic cellophane, and stored in a wet room for one week to cure. This was necessary because of the cementation reactions which occur in the Lurgi shale from wetting.

Using the leaching apparatus, specimens were permeated with distilled water at a $138 \mathrm{kPa}$ differential gradient with a $172 \mathrm{kPa}$ confining pressure. $25 \mathrm{ml}$ of leachate was collected from each 
specimen for every $125 \mathrm{ml}$ of total leachate produced. $25 \mathrm{ml}$ represent approximately one pore volume. In effect, one pore volume was collected for analysis on every five pore volumes of leachate that was produced.

Leachate samples were analyzed to determine concentrations of sodium, chloride, sulfate, magnesium, calcium, and total alkalinity. EPA standard procedures were used for all chemical analyses.

\subsubsection{Results of Leachate Chemistry Analysis}

Figures 3.15 through 3.20 show mean results from column leaching tests for sodium, chloride, sulfate, magnesium, calcium and total alkalinity respectively. Most of the constituents measured showed typical S-shaped breakthrough curves and leaching behavior. The concentration of the constituents being measured reduces eventually becoming asymptotic. Effects of leaching behavior caused by preparing the specimens at 15 and 20 percent water contents are not apparent for any of the constituents except for calcium (Figure 3.19). The leaching of calcium becomes asymptotic approximately $100 \mathrm{mg} / \mathrm{higher}$ when the processed oil shale was prepared at 15 percent than at 20 percent. This result may indicate the importance of calcium as a constituent in secondary mineral formation during hydration and cementation of the processed oil shale. Cementation reactions involving calcium may have been incomplete when the processed oil shale was hydrated with 15 percent water. As leaching of the specimens was initiated, cementation reactions may have also occurred causing calcium to be tied up in the formation of secondary minerals. 


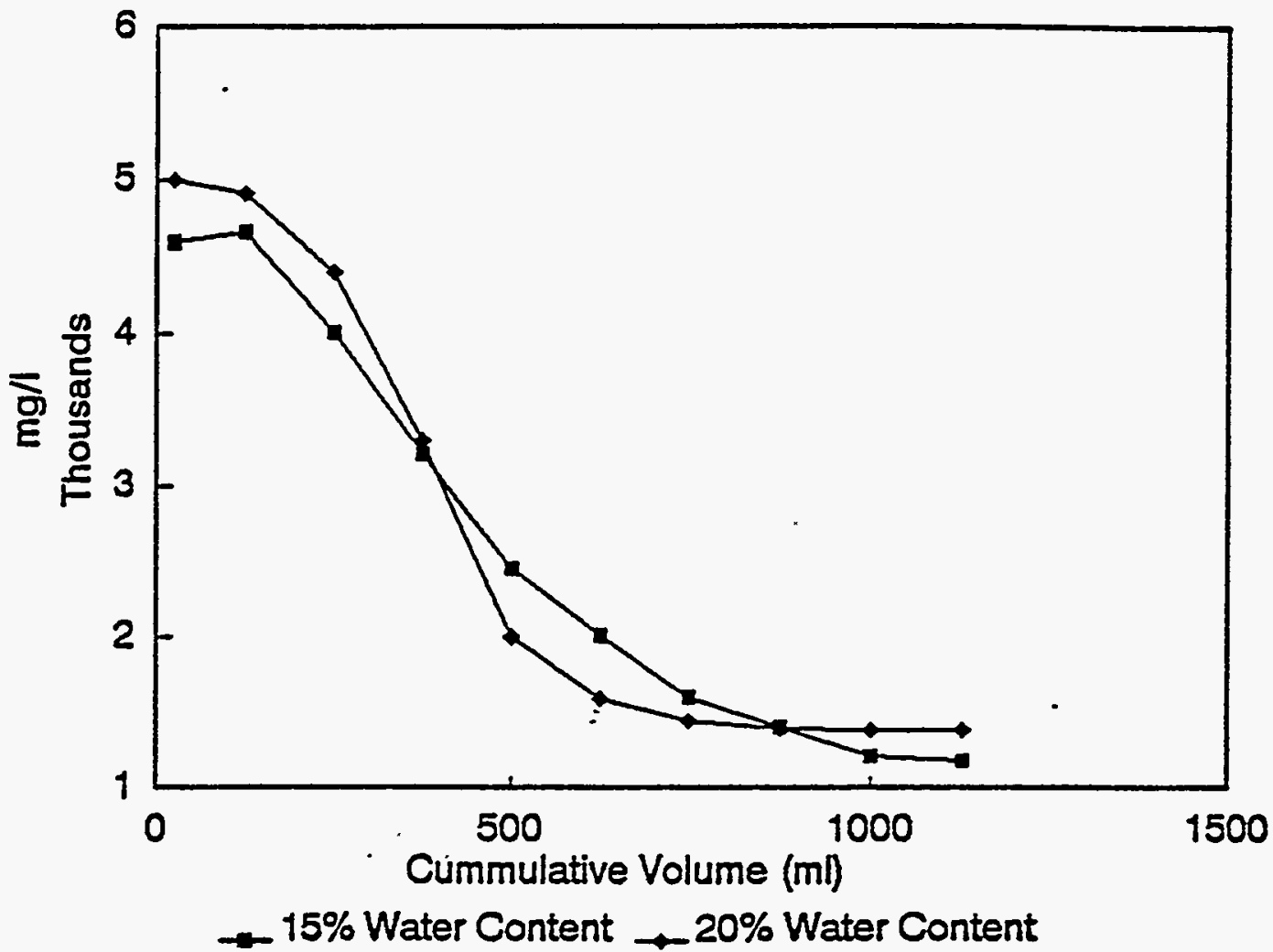

Figure 3.15. Sodium $(\mathrm{Na}+)$ concentration by cumulative volume of leachate for processed oil shale cores prepared at 15 and 20 percent water content 


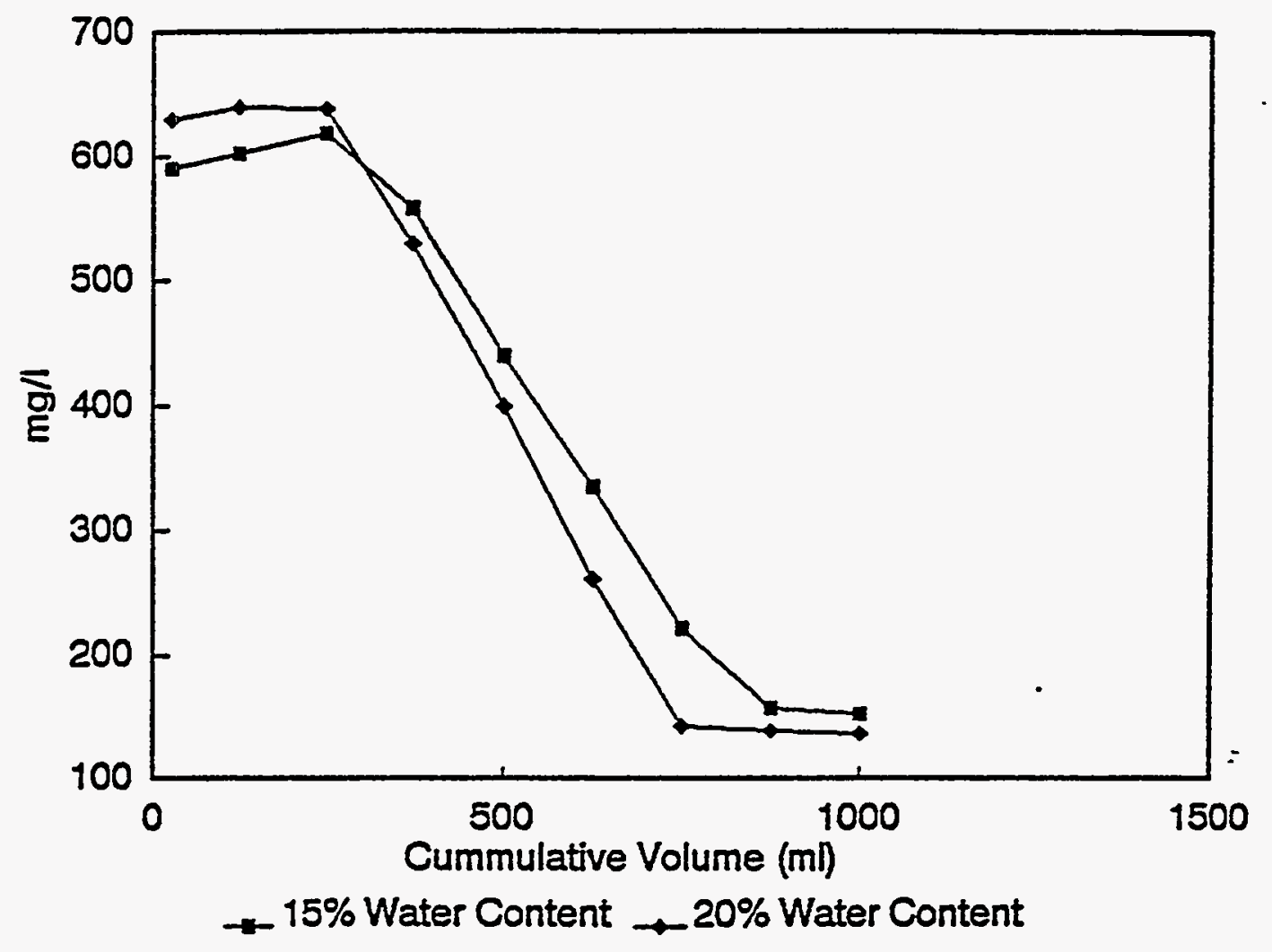

Figure 3.16. Chloride $(\mathrm{Cl})$ concentration by cumulative volume of leachate for processed oil shale cores prepared at 15 and 20 percent water content 


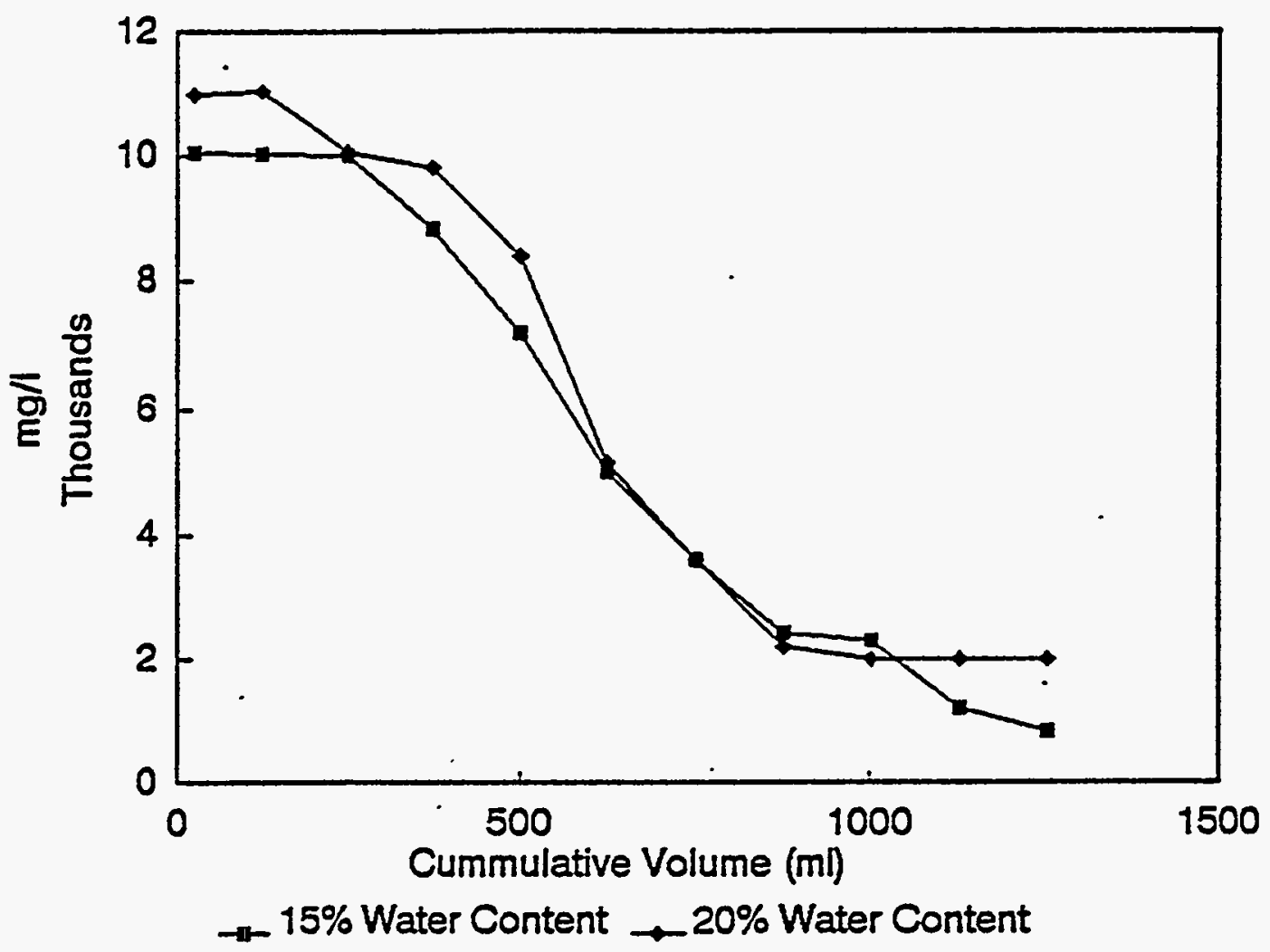

Figure 3.17. Sulfate $\left(\mathrm{SO}_{4}^{-2}\right)$ concentration by cumulative volume of leachate for processed oil shale cores prepared at 15 and 20 percent water content 


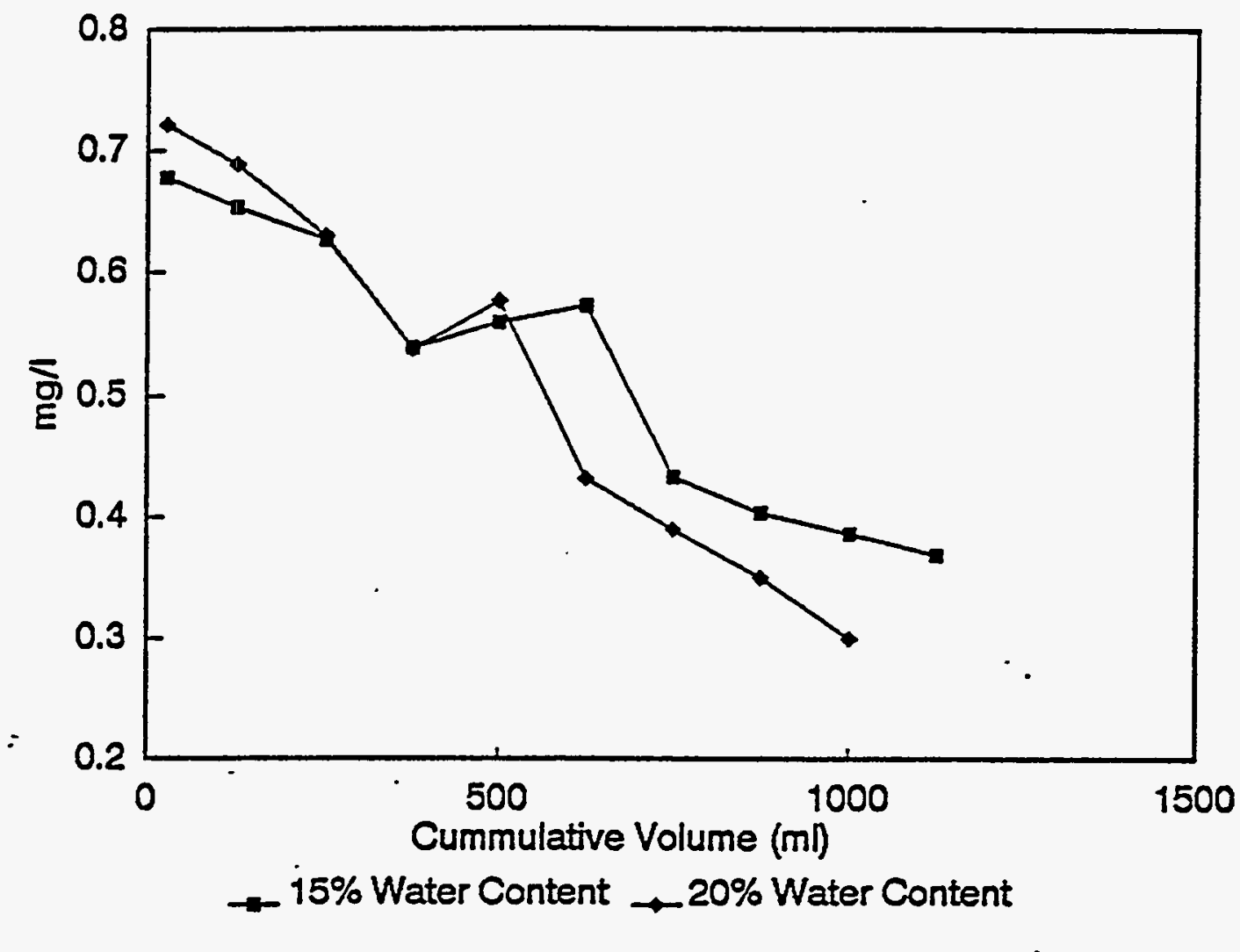

Figure 3.18. Magnesium $\left(\mathrm{Mg}^{+2}\right)$ concentration by cumulative volume of leachate for processed oil shale cores prepared at 15 and 20 percent water content 


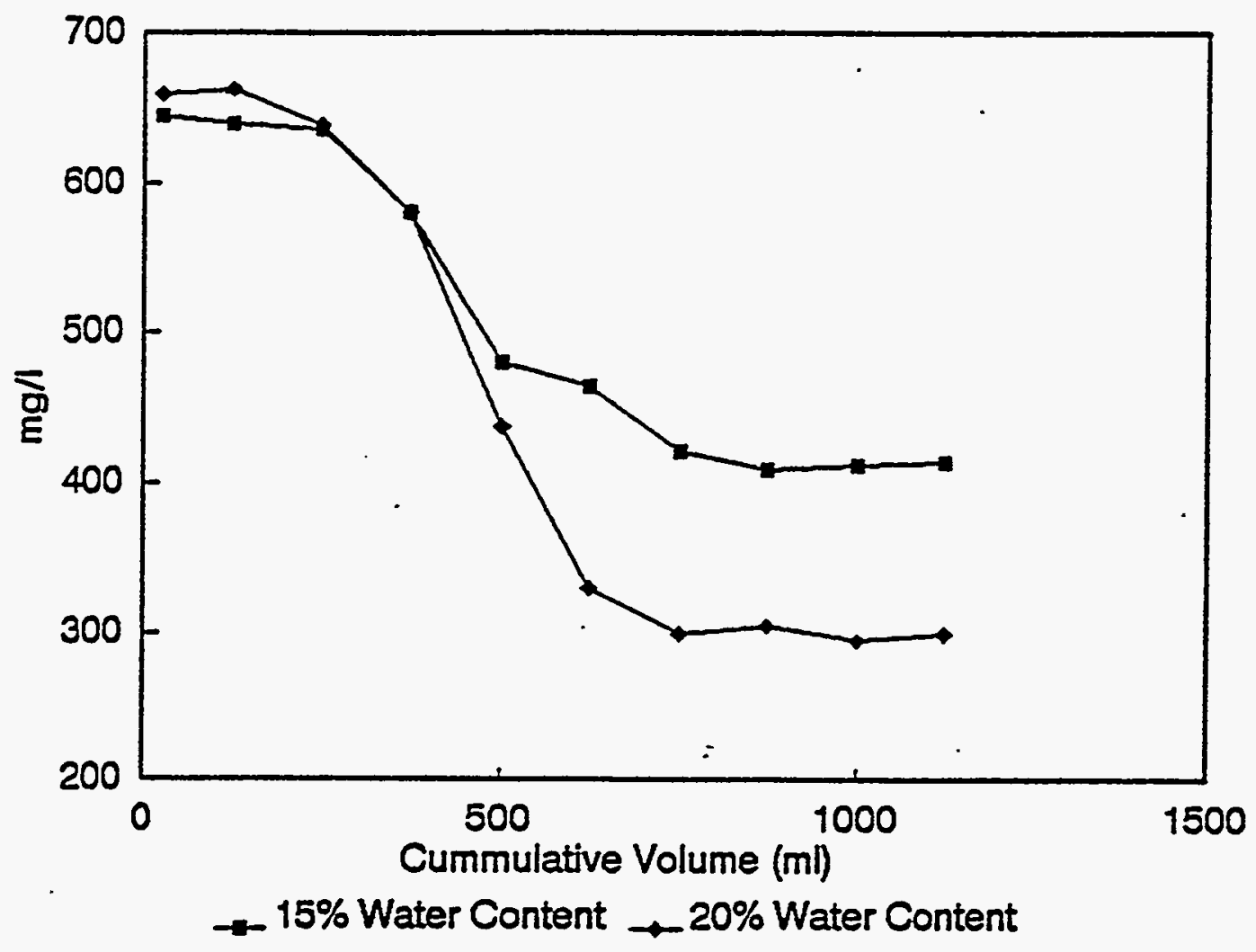

Figure 3.19 Calcium $\left(\mathrm{Ca}^{2+}\right)$ concentration by cumulative volume of leachate for processed oil shale cores prepared at 15 and 20 percent water content 


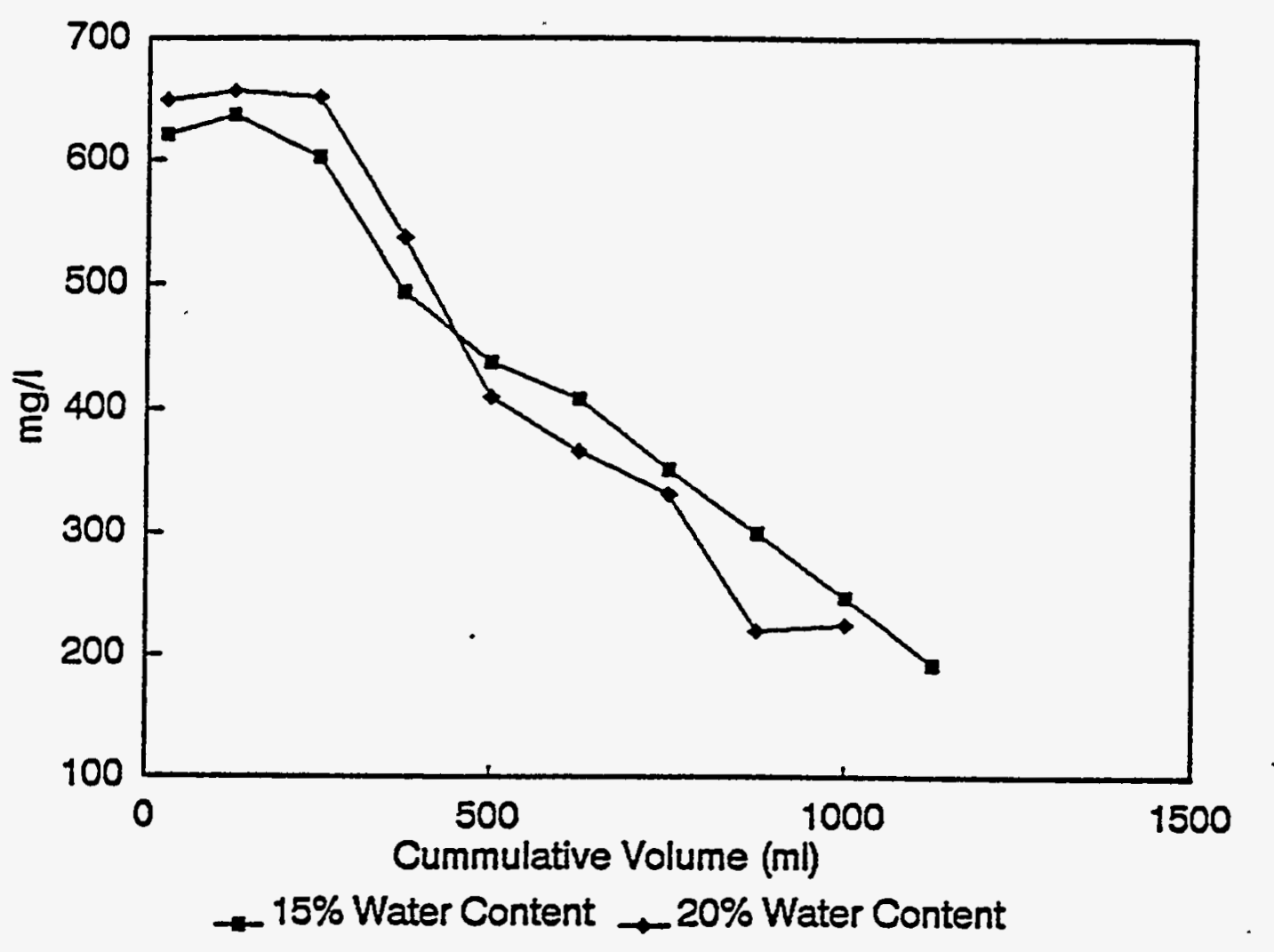

Figure 3.20. Total alkalinity by cumulative volume of leachate for processed oil shale cores prepared at 15 and 20 percent water content 


\subsection{HYDROLOGIC RESPONSE TO SIMULATED CLIMATIC CONDITIONS}

An experimental program was designed and carried out to evaluate the hydrologic response of large-scale model waste embankments to simulated climatic conditions. Two model waste embankments were constructed in the Environmental Simulation Laboratory (ESL) at the University of Wyoming, and three were constructed at a field site on Federal Tract C-a in the Piceance Creek Basin, Colorado. The experiments involved: (1) monitoring the infiltration and movement of water in the waste embankments under simulated climatic conditions; (2) measuring the in situ vertical and horizontal hydraulic conductivities of spent shale in the model waste embankments; and (3) evaluating in situ hydraulic conductivities based on the soil-moisture characteristic curve and measured in situ moisture contents.

This section describes construction and instrumentation of the model embankments, methods used to monitor moisture movements, in situ hydraulic conductivity and infiltration tests, the climatic simulation program, and results. Results of runoff, infiltration, and seepage measurements are presented in Section 5, for comparison with results of numerical modeling.

\subsection{Construction of Model Embankments}

\subsubsection{The Environmental Simulation Laboratory}

Model embankments were constructed in the Environmental Simulation Laboratory (ESL) at the University of Wyoming. The ESL consists of an environmental chamber which is a $7 \times 6 \mathrm{~m}$ closed room constructed of environmental freezer panels, lysimeter cells, and a computer driving system. The chamber houses two lysimeter cells each $7.3 \times 3.0 \times 3.0 \mathrm{~m}$ deep. The environment inside the chamber is precisely controlled for ambient temperature, relative humidity, rainfall, and radiant flux by computer. Construction materials for the ESL were all available commercially.

The freezer panels of the environmental chamber consist of an interior sheet of stainless 
steel, a middle layer of insulating foam, and an outside layer of porcelain. The stainless steel coating was chosen for the inside of the panels to provide chemical resistance. The insulating foam on the inside of the panel was chosen over fiberglass type layers which were also available. The foam insulation resists ice build up during freezing temperatures.

The lysimeter cells are constructed of concrete, insulated on the interior side with tapered foam sheets, providing a greater thickness at the bottom of the chamber. The tapered design was used to aid soil materials with expansive properties during wetting or freeze-thaw cycles to expand upward and not create horizontal loads against the concrete walls of the cells.

The environmental control system is designed to produce rapid changes in temperature and control relative humidity at a wide range of temperatures. The air throughput is driven by a ten horsepower fan that can use outside air providing an open system, or continuously recirculate the air for a closed system. The system throughput is 40 complete air exchanges per hour. The precision with which temperature and humidity is controlled is maximized by operating the ESL as a closed system.

Environmental conditions are adjusted through the use of two-phased air conditioning, freezing, and heating units. A steam generator raises relative humidity in the system. Dehumidification is accomplished through the air conditioning and freezing system. The high throughput of the system provides excellent precision in temperature and humidity control and provides fast responses to desired changes in temperature and humidity. Ambient chamber temperatures can be regulated between $-29^{\circ} \mathrm{C}$ to $48^{\circ} \mathrm{C} \pm 2^{\circ}$.

Relative humidity can be generally regulated from $30 \%$ to $90 \% \pm 5 \%$ at all temperatures between $-29^{\circ} \mathrm{C}$ and $48^{\circ} \mathrm{C}$. Control becomes more difficult near the temperature extremes. As ambient temperatures approach $-29^{\circ}$ the system has difficulty lowering relative humidity below $30 \%$. As ambient temperature approach $48^{\circ}$ the system has difficulty maintaining relative humidity above $90 \%$. The system easily regulates relative humidity between $20 \%$ and $95 \%$ at temperatures between 
$0^{\circ}$ and $32^{\circ} \mathrm{C}$.

Lighting is provided by 24 metal halide lights that produce solar radiant flux between 0 and $53,000 \mathrm{Im} / \mathrm{m}^{2}$ intensity. The lights are located eight feet above the surface of the lysimeter plots. The total radiant flux is approximately $80 \%$ of that of natural sunlight at sea level. The light quality is between 390 to $700 \mathrm{~nm}$ wavelength and is proportioned to be adequate for plant growth. Desired intensity levels are regulated by controlling the number of lights that are on at any given time. Activation of individual lights is rotated randomly by the computer system to provide an even distribution of flux over the plot surface.

Rainfall can be produced at rates between 0 and $127 \mathrm{~mm} / \mathrm{hr}$ by Lafayette ${ }^{1}$ rainfall simulators. The simulators were designed and constructed by personnel at Lafayette and shipped to UW in 1988. Research performed at Lafayette has shown that these simulators produce a distribution of raindrop sizes that is similar to that of runoff producing storms in the Midwest region of the U.S. Raindrop size distribution does not change with different rainfall intensities or the energy of terminal velocity. Electronic systems, a computer controlled driver, and a computer rainfall modeling program were developed specifically for the rainfall simulators in the ESL. Using the computer system, rainfall hyetographs (i.e. a rainfall time-intensity distribution) are designed, modeled, and physically applied in the ESL.

\subsubsection{Test Embankments}

RBOSC designed and engineered three field lysimeters based on recommendations of UW personnel and the RBOSC objectives for the study. The lysimeters were designed to be the same size as the two lysimeter cells designed and proposed for the ESL at UW. The field lysimeters were constructed of plywood, timber, and steel. The cells were excavated into a naturally-existing slope at Tract C-a. The hillside design allowed for easy placement of the spent shale into the lysimeter

'Designed at the United States Department of Agriculture Science and Education Administration (USDA-SEA) Erosion Research Unit, Lafayette, Indiana. 
cells and provided for the top of the cells to match the normal landscape at the top of the embankment.

Lurgi-processed oil shale was placed in the three lysimeters at the RBOSC site in September 1987. Index and engineering properties of the spent shale determined by bench-scale tests are described in the preceding section (Section 3) of this report. Each lysimeter cell represented a different disposal scenario or treatment. Cell 1 was filled with the Lurgi-processed oil shale. Cell 2 was filled with a mixture of processed oil shale and overburden waste, then covered with a $76 \mathrm{~cm}$ soil surface cap. The overburden waste consisted of low-grade unprocessed oil shale crushed to $15 \mathrm{~cm}$ ( 6 inch) nominal. The mixture was $60 \%$ by weight of processed oil shale to $40 \%$ overburden. Cell 3 was filled with $61 \mathrm{~cm}$ of Lurgi-processed spent shale, $1.8 \mathrm{~m}$ of overburden to act as a hydraulic barrier, and $46 \mathrm{~cm}$ of top soil. The processed oil shale for all three cells was mixed to a water content of $15 \%$ by weight in a commercial cement mixer and placed in $30.5 \mathrm{~cm}$ lifts. Lifts were compacted to approximately $12 \mathrm{kN} / \mathrm{m}^{3}$ (76.3 pcf) dry density using a manually driven vibratory compactor. Compaction was not applied to the top soil layers.

Processed oil shale was placed in the two lysimeters of the ESL at UW in October 1989. Cell 1 of the ESL was filled with Lurgi-processed spent shale and Cell 2 with a mixture of 60 percent by weight of processed oil shale and 40 percent by weight of low-grade unprocessed oil shale crushed to $15 \mathrm{~cm}(6 \mathrm{in})$ nominal. These cells are duplicates of Cells 1 and 2 at the RBOSC site except that a top-soil surface cap was not placed in cell 2. Repeating the methods used at RBOSC, the spent shale was mixed to a water content of 15 percent by weight in a commercial ready-mix concrete truck and placed in $0.31 \mathrm{~m}$ (12 in) thick lifts. Lifts were compacted to a dry density of approximately $12 \mathrm{kN} / \mathrm{m}^{3}$ (76.3 pcf) using a manually driven vibratory compactor. Figure 4.1 shows the environmental chamber with the compacted spent shale in the lysimeter. 


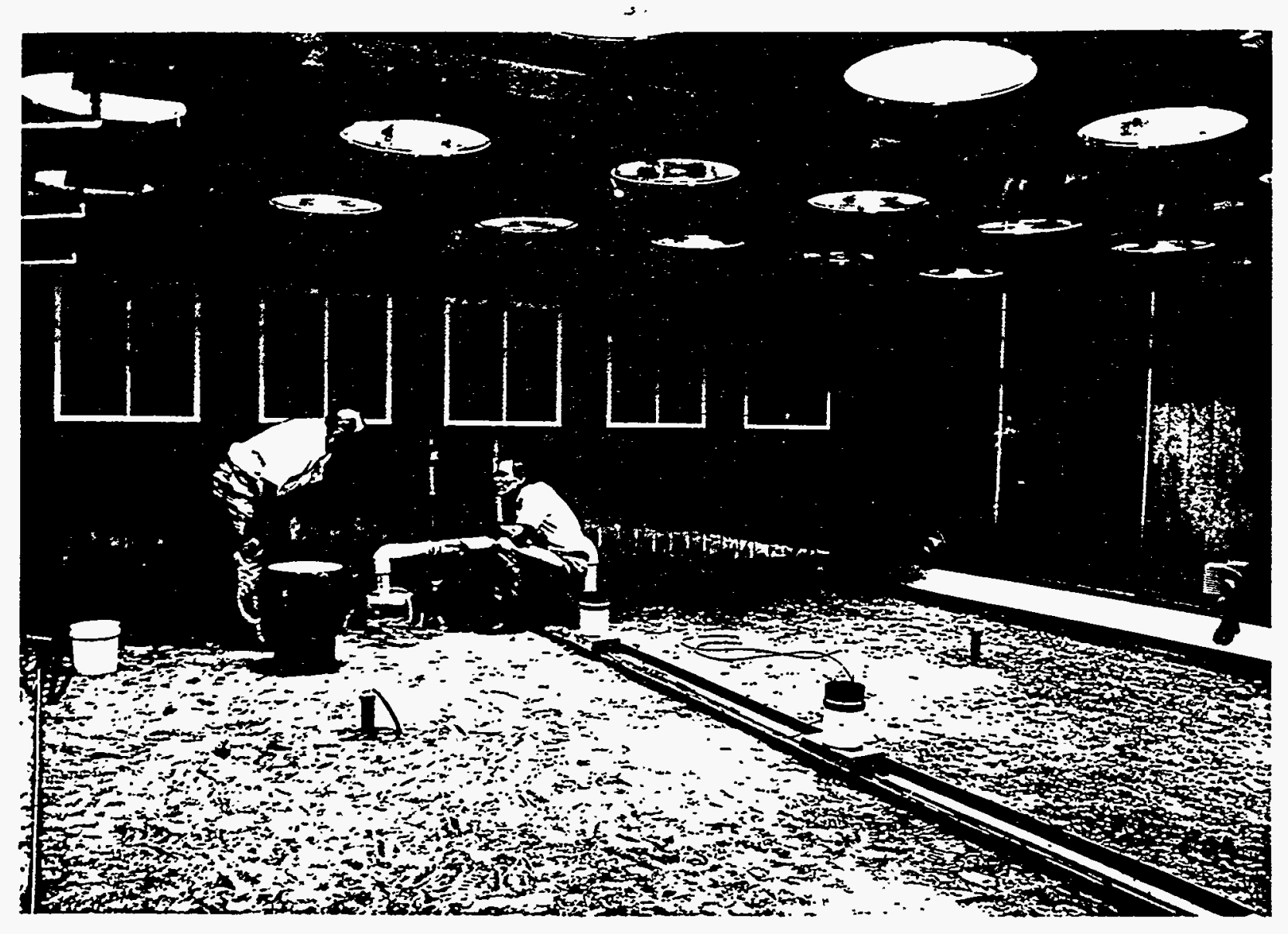

Figure 4.1 Environmental chamber and spent shale 


\subsection{In Situ Instrumentation}

Instrumentation was installed in the spent shale test embankments to monitor moisture content, temperature, and the state of stress. To monitor water movement and water content at different depths, two types of instrumentation were installed as the lifts were placed. These were (1) neutron moderation and (2) time domain reflectometry, or TDR.

\subsubsection{Neutron Moderation}

Neutron moderation works on the principle of thermalization of fast neutrons by hydrogen atoms present in soil water. Fast neutrons are emitted from a source into the soil. Collisions with hydrogen atoms cause the velocity of the neutrons to decrease. Eventually the neutrons are slowed to velocities at which further collisions with hydrogen or other molecules will not result in any further decrease in neutron velocity. The number of fast neutrons measured by the receiver thus provides a quantitative measure of hydrogen concentration, and therefore water content, in the soil.

To measure moisture contents in the processed oil shale, a Troxler Model 4300 Depth Moisture Gauge was used. During construction of the lifts, aluminum access tubes of $50 \mathrm{~mm}$ diameter were installed to facilitate insertion and removal of the neutron probe. At both the RBOSC site and in the ESL, two access tubes were placed in each lysimeter. Each tube was placed at a distance of $2.3 \mathrm{~m}$ from the end of the lysimeter, and centered in the longitudinal direction. The gauge was calibrated by taking a core sample and weighing the sample before and after drying to arrive at a moisture content. This value was input to the control unit and stored to be recalled at any time to give an accurate reading of moisture content in the processed shale. To make a reading, the probe was lowered to the required depth and the testing mode activated. Fast moving neutrons are emitted from the probe into the soil. After a set time interval when thermalization takes place, the reading on the display window is recorded to give the moisture content at that depth. The readings were recorded at various depths to obtain the moisture profile of the processed oil shale. 
Water content was monitored before and after each rainstorm using the neutron probe.

\subsubsection{Time Domain Reflectometry (TDR)}

The second method of measuring moisture content in the lysimeter was by TDR probes that were installed in the spent shale during construction of the embankment. The TDR principle involves propagating an electromagnetic pulse along a transmission line and analyzing the reflected signal from wave guides or probes placed in the soil. The reflected signal is recorded on an oscilloscope. The TDR probes consists of two or more parallel rods placed a small distance apart which act as wave guides for the pulse being transmitted through the soil. The practical application of TDR for measuring volumetric soil water by a reliable and accurate technique is described by Topp et al. (1990). The method is based on a strong relationship between the complex dielectric constant $[K(w)]$ and the volumetric water content given by the equation

$$
K^{\prime}(w)=K^{\prime}(w)-j K^{\prime \prime}(w)
$$

where: $K^{\prime}(w)=$ the real part of dielectric constant $K^{\prime \prime}(W)=$ the dielectric loss

At high frequencies, $K^{\prime \prime}(w) \ll K^{\prime}(w)$; hence for a homogenous material, apparent dielectric constant $K_{a}$ is assumed to be equal to $K^{\prime}(w)$. This technique has been investigated in several soils and other porous media. It was found that the apparent dielectric constant is independent of bulk density, soil type, particle distribution, and salt content. Salt solutions tested in porous media to evaluate TDR had electrical conductivities below $0.4 \mathrm{~S} / \mathrm{m}$. When using TDR in spent shale, the assumption that $K_{a}=K^{\prime}(w)$ is no longer valid when the bulk density is greater than $1.5 \mathrm{~S} / \mathrm{m}$ and neither is the calculation of volumetric water content.

For this study, TDR probes were designed to be buried in the embankments. Design requirements were that they be durable under vibratory or roller compaction techniques, resistant to highly alkaline and saline environment, and capable of measuring water content. Probes were 
designed with two stainless steel rods of $10 \mathrm{~cm}$ (3.94 in) length, $0.64 \mathrm{~cm}$ in diameter and mounted parallel with $4 \mathrm{~cm}$ (1.57 in) spacing in a PVC plastic box as shown in Figure 4.2.

A balun impedance matching transformer was used for electrical connection between the wave guides and the coaxial cable. The balun transformer was mounted as close as possible to the top of the rod to minimize voltage loss after the pulse was converted from an unbalanced to a balanced signal by the transformer.

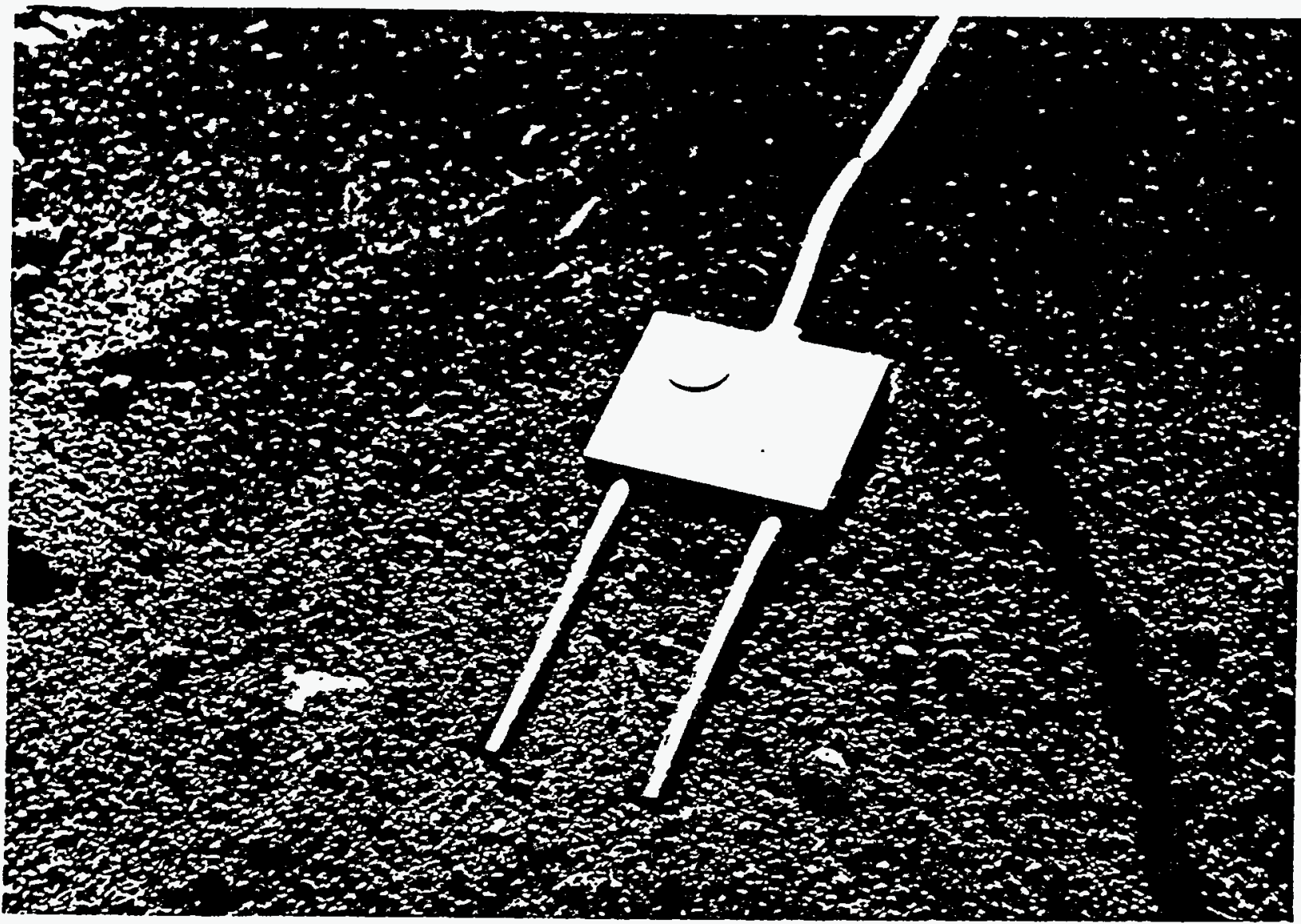

Figure 4.2 TDR probe used in this study 
To verify the design, spent shale was prepared at water contents varying between 4 and 27 percent by weight and packed into columns of $10.2 \mathrm{~cm}$ ( $4 \mathrm{in})$ diameter and $12 \mathrm{~cm}(4.72 \mathrm{in})$ high in two lifts at dry densities between 11 and $14 \mathrm{kN} / \mathrm{m}^{3}$ (70 and $89 \mathrm{pcf}$ ) depending on the water content. A TDR probe was inserted vertically into each column. A real time data acquisition and control system were used to digitize the TDR trace returned to the Tektronix 1502 TDR cable tester. The output signal was used to develop a correlation between volumetric water content and TDR signal for the spent shale, which was used in all subsequent field and ESL measurements.

TDR probes were installed in the field lysimeters and in both cells of the ESL. Vertical "instrument trees" consisting of plastic pipe were installed before placement of the spent shale. Each field lysimeter had two instrument trees and each lysimeter in the ESL had three. The instrument trees were placed at equal spacing along the centerline of the lysimeter in the longitudinal direction. Following completion of a lift, three TDR probes (one per tree) were placed on the surface of the spent shale and the cables were run into the instrument trees, through which they were directed to the data acquisition system. The depths at which TDR probes were placed are listed in Table 4.1. Figure 4.3 shows a TDR being placed on top of one of the spent shale lifts in the ESL. During the course of this study, twenty-two rainstorms were applied to the processed oil shale in the ESL Water content was monitored before and after each rainstorm using TDR probes. Results are presented and analyzed in Section 5.

\section{Table 4.1 Depth of TDR probes in ESL ${ }^{1}$}

\begin{tabular}{cl}
\hline 5 & 61 \\
10 & 76 \\
15 & 152 \\
30 & 244 \\
46 & 274 \\
\hline
\end{tabular}

${ }^{1} 3$ probes were installed at each depth, in each of 2 cells 


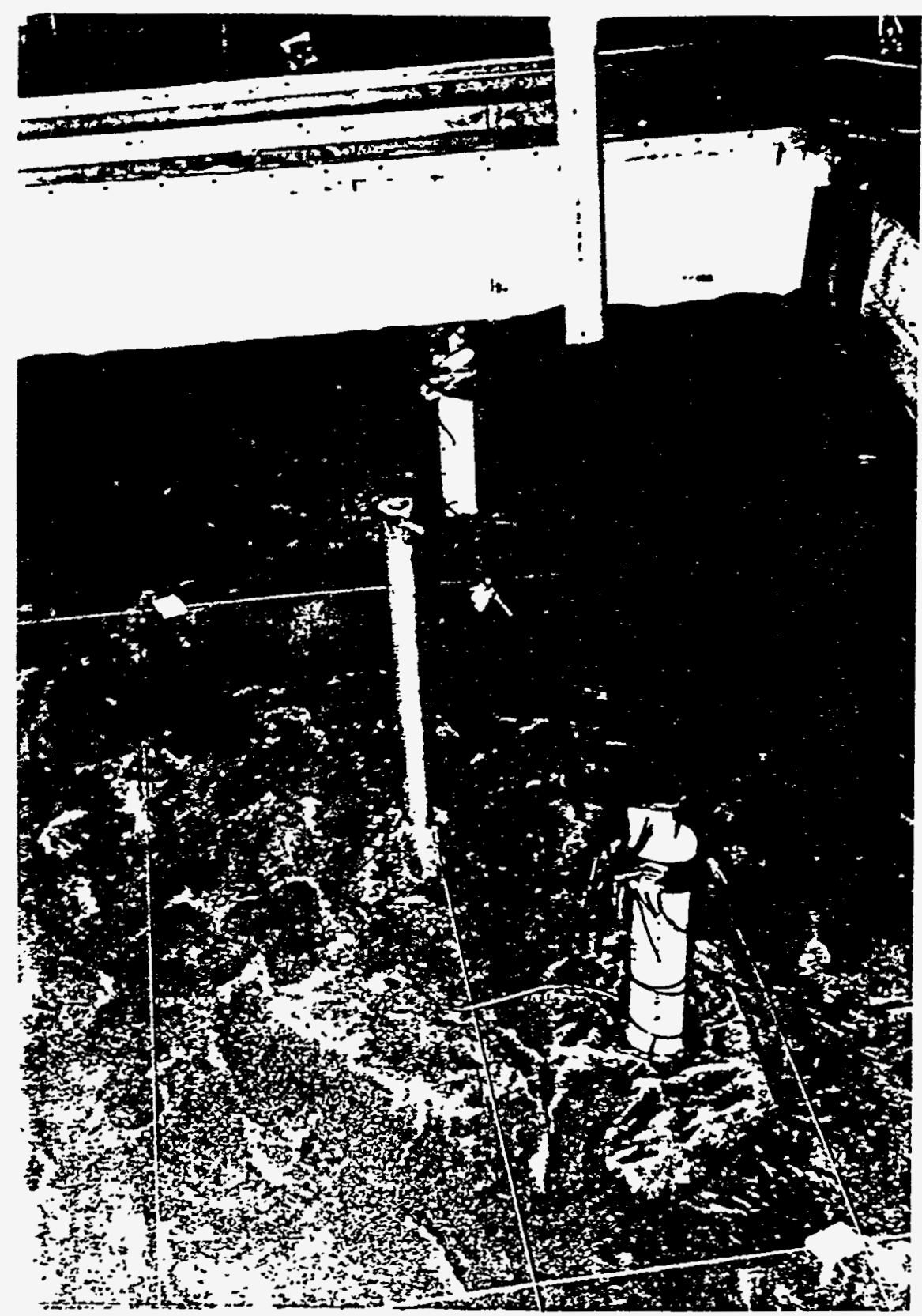

Figure 4.3 TDR probe placed over spent shale lift 


\subsubsection{Temperature Measurements}

Thermocouples were installed to monitor temperature at various depths. Automatic data logging systems were used at the RBOSC site and in the ESL to record thermocouple output signals. Thermocouples were installed at depths of $10,30,46,76,152$, and $244 \mathrm{~cm}$ to monitor subsurface temperatures and the cables were installed through the instrument trees, as described for TDR probes. The thermocouples at the RBOSC site were monitored monthly, while those in the ESL test embankments were monitored more frequently, depending upon the climatic simulation schedule.

\subsubsection{In Situ State of Stress}

Total stress cells were installed at both the RBOSC lysimeters and in the ESL at depths of 76,152 , and $244 \mathrm{~cm}$. At each depth, two cells were installed, one to measure total vertical stress and one to measure horizontal stress. Cables from the stress cells also were installed through the instrument trees.

\subsection{In Situ Testing Methods}

\subsubsection{Infiltration and Vertical Hydraulic Conductivity}

To determine the rate of infiltration and vertical hydraulic conductivity, a double ring infiltrometer was used. The double ring infiltrometer is based on Darcy's law and measurement of the constant rate of infiltration into the soil under a constant head of water that is ponded above the surface. Tests were conducted on the surface and at different depths in the ESL. The double ring infiltrometer consists of two open cylinders approximately $0.50 \mathrm{~m}$ (19.68 in) high and having diameters of about $0.30 \mathrm{~m}$ (12 in) and $0.60 \mathrm{~m}$ (24 in). Two calibrated head tanks are used for measurement of water flow during the test. These tanks may be either graduated cylinders or Mariotte tubes. Larger diameter cylinders may be used, provided the ratio of the outer to inner cylinders is about two. The test site should be nearly level, or a level surface should be prepared. 
The method consists of driving the two open end cylinders concentrically into the ground with a sledge hammer as shown in Figure 4.4. Since the surface of the spent shale was hard and subjected to possible cracking during driving of the rings, a routing technique was used to place the rings. The method consisted of using a routing tool to cut grooves along the edges of the two rings in spent shale to the required depth so that the rings could be placed. To prevent leakage from under the rings and to achieve vertical infiltration, a mixture of spent shale and bentonite slurry was placed in the grooves before placing the rings. The outer cylinder is first placed and the inner cylinder is centered inside the outer cylinder. The outer cylinder is generally placed deeper than the inner cylinder to promote one dimensional vertical flow beneath the inner cylinder. If the surface of the soil surrounding the wall of the cylinder(s) was slightly disturbed, the disturbed soil was tamped adjacent to the inside and outside of the cylinders until the soil was as firm as it was prior to disturbance.

To maintain a constant head of water within the inner cylinder and the annular space between cylinders, Mariotte tubes were used. The Mariotte tubes were installed in such a manner that a constant head of $2.54 \mathrm{~cm}$ (1 in) of water was applied. To prevent erosion of soil when the initial water was applied into the cylinders, splash guards of burlap was used. A constant head of $2.54 \mathrm{~cm}$ ( $1 \mathrm{in})$ of water was applied within both the cylinders. The water level at the selected head was maintained as near as possible throughout the test to prevent flow of water from one ring to the other. The volume of water recharged to the inner ring from the Mariotte tube to maintain constant head is the volume of water that infiltrates into the soil. The change in the volume of water in the Mariotte tube is recorded against time. The volume infiltrated during timed intervals is converted to an incremental infiltration velocity. The average incremental velocity is equivalent to the infiltration rate. Vertical hydraulic conductivity was obtained indirectly from infiltration rate and change in water content with time. Figure 4.5 shows the set up of double ring infiltrometer. 


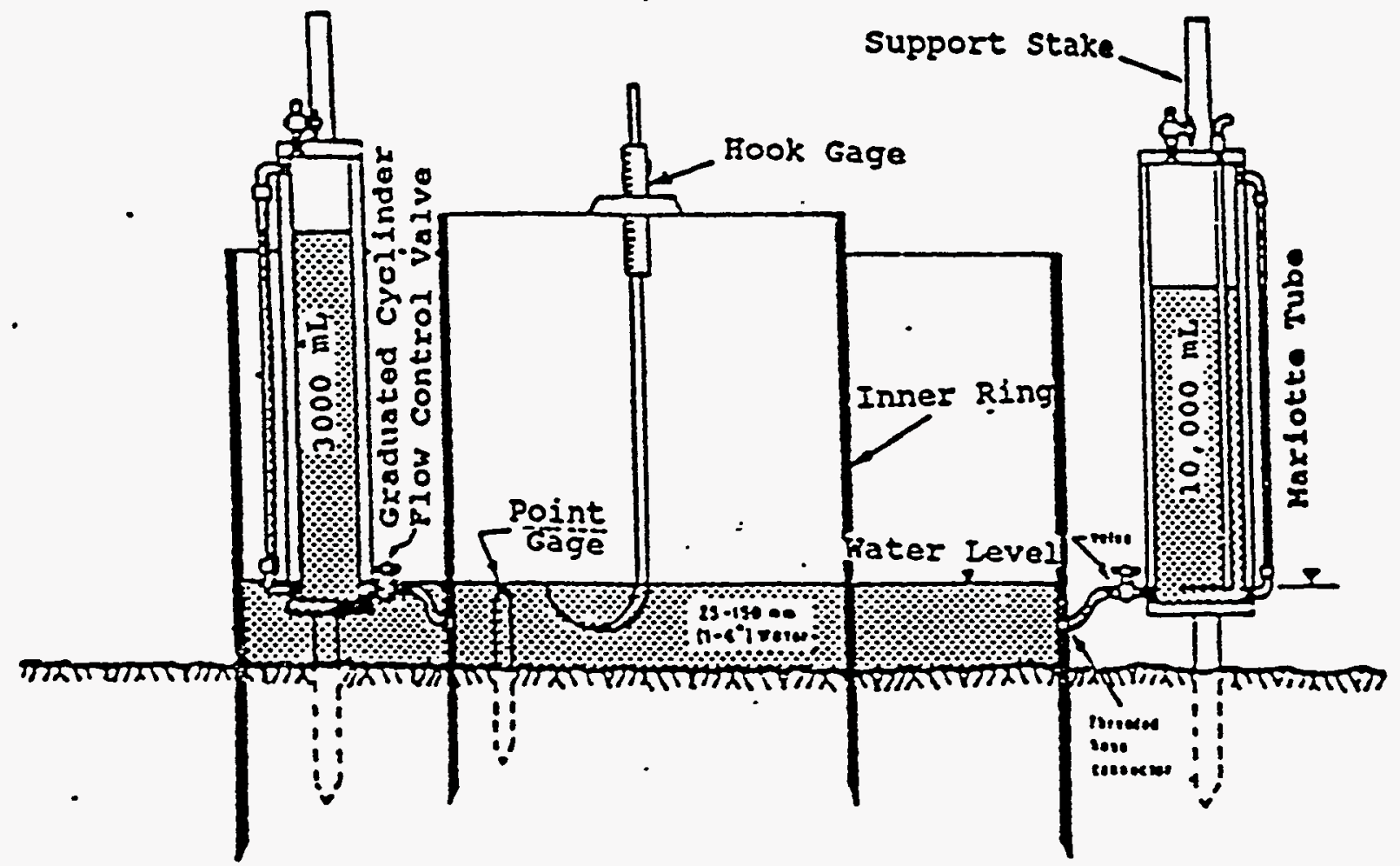

Figure 4.4. Double ring infiltrometer assembly

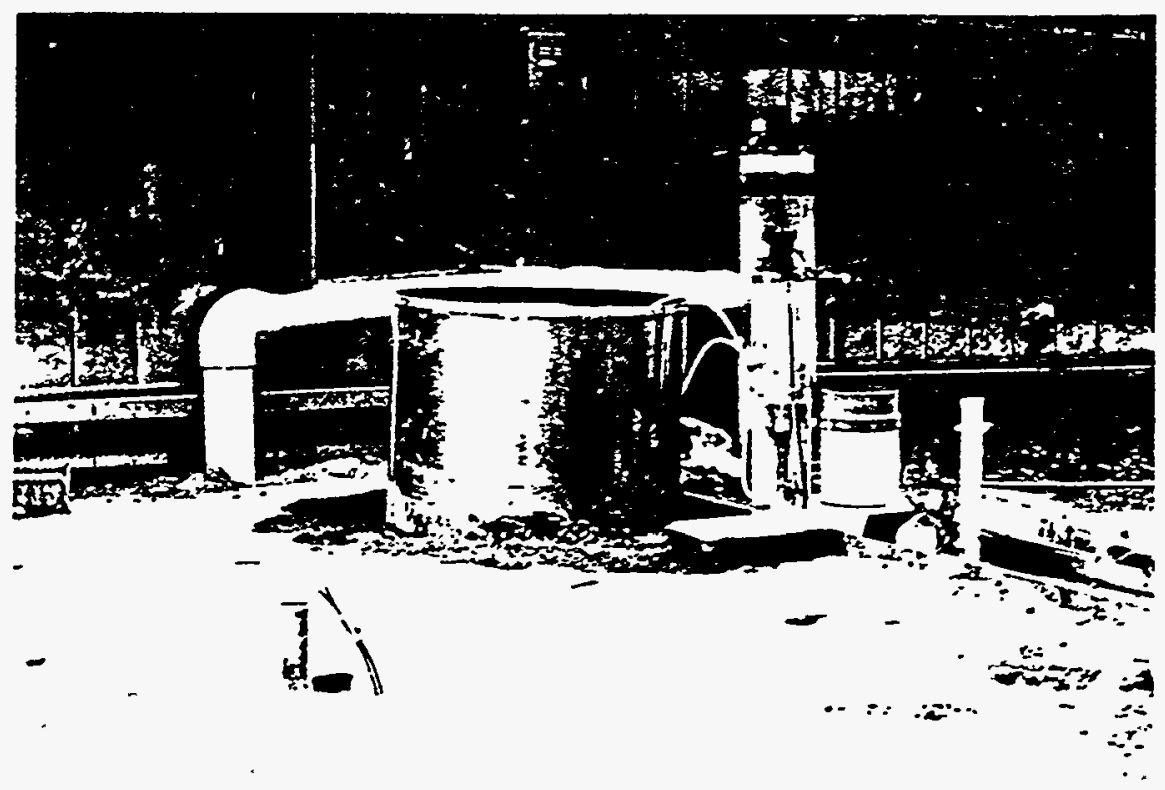

Figure 4.5. Double ring infiltrometer 


\subsubsection{Horizontal Hydraulic Conductivity}

A Guelph permeameter was used to measure the horizontal hydraulic conductivity. The Guelph permeameter is an in-hole constant head permeameter. The principle involves measurement of steady-state rate of water recharge into unsaturated soil from a cylindrical well hole in which a constant head of water is maintained. The permeameter consists of a reservoir and an air tube, as shown in Figure 4.6.

The reservoir assembly provides a means of storing water and measuring the outflow rate while the permeameter is in use. The constant head level in the well hole is established and maintained by regulating the level of air in the bottom of a tube that is located in the center of the permeameter.

The method consists of auguring a well hole to the required depth at which the horizontal conductivity is to be measured. Using a sizing auger as a finishing tool, the debris at the bottom of well hole is removed. Centering the tripod over the hole, the permeameter is lowered slowly into the hole, being careful not to knock debris off the sides of the well, until the water outlet tip rests against the bottom of the well. To determine the horizontal hydraulic conductivity of the, two tests, each with a different head of water, are required. The reservoir is filled with water and plugged. The air inlet tip is raised slowly to establish the first well head $\left(H_{1}\right)$. Raising the air tube too quickly can cause turbulence and erosion in the well.

As the water level in the reservoir falls to maintain a constant head in the well, a vacuum is created in the air space above the water in the reservoir. This vacuum can only be relieved when air, which enters at the top of the air tube, bubbles out of the air inlet tip and rises to the top of the reservoir. As the water permeates into the unsaturated soil, the water level in the well drops below the air inlet tip. Because of the vacuum, air is drawn through the air tube. Bubbles emerge from the tip and rise into the reservoir air space, partially relieving the vacuum, and water from the reservoir replenishes water in the well. The size of opening and geometry of air inlet tip is designed to control 


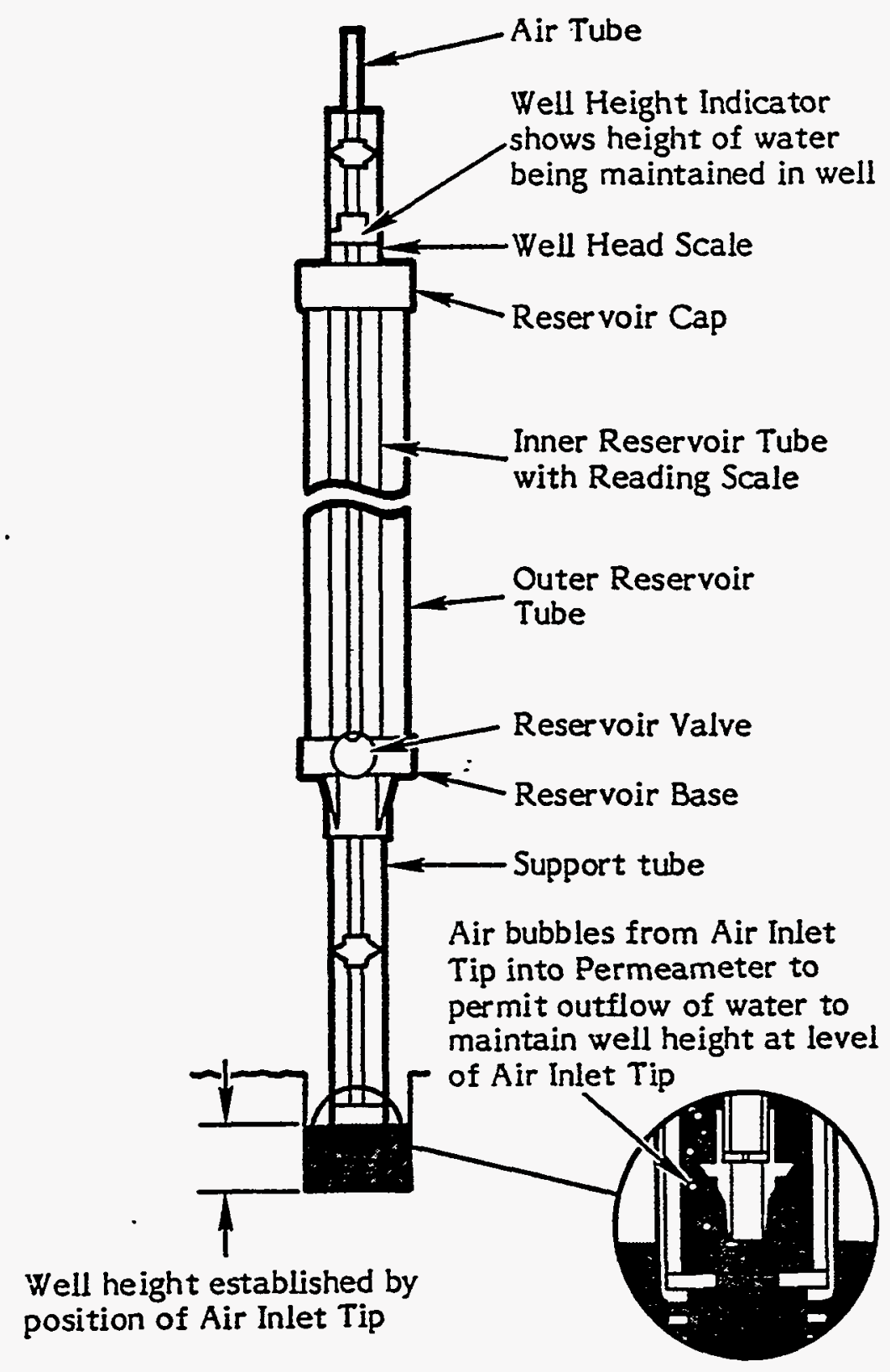

Figure 4.6. Guelph permeameter assembly 
the size of the air bubbles in order to prevent the well water level from fluctuating. The steady rate of recharge of water $\left(R_{1}\right)$ into the reservoir was recorded. The steady rate of recharge of water was monitored until there was no significant change in three consecutive time intervals.

The air tube is raised to establish the second well head $\left(\mathrm{H}_{2}\right)$ and the above procedure is repeated to obtain a steady- state recharge of water $\left(\mathbf{R}_{2}\right)$. Using Richard's analysis for three dimensional flow of water into unsaturated soil, the in situ horizontal hydraulic conductivity was calculated. Figure 4.7 shows the setup of Guelph permeameter test in the laboratory.

\subsection{Back Calculation Technique}

In situ hydraulic conductivity of spent shale in the ESL was estimated from measurements of volumetric flux of water, estimated hydraulic gradients, and Darcy's law. Volumetric flux of water was determined by considering the change in water content between two depths, at varying time intervals. The change in water content is the area between the two soil moisture profiles obtained by planimetry. The hydraulic gradient was determined by converting the soil moisture measurements to soil suction, based on the soil-moisture characteristic curve presented in Section 3 of this report.

For each water content at two depths, the matric suction or suction head was obtained from the soil-moisture characteristic curve. Knowing the elevations of the two depths, total head is calculated as a summation of suction head and elevation head. Hydraulic gradient is then the ratio of the difference between the total heads at the two depths to the distance between them. An average hydraulic gradient was obtained before and after each rain storm. By Darcy's law, the hydraulic conductivity is the volumetric water content divided by the hydraulic gradient.

\subsection{Climatic Simulation}

\subsubsection{RBOSC Field Site}

A seff-logging meteorologic station was installed at the field site. The data logging station 


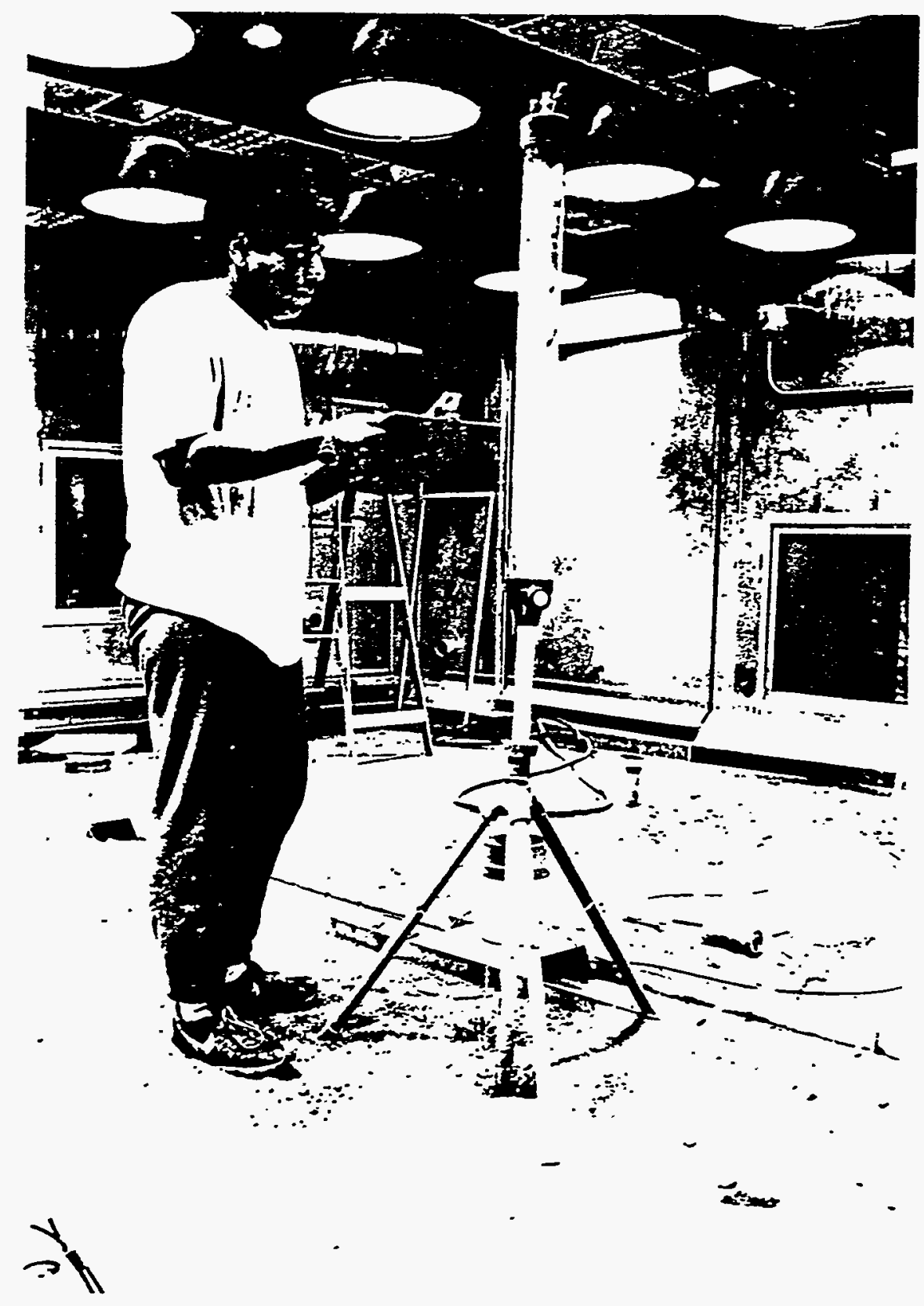

Figure 4.7 Guelph permeameter laboratory setup 
could be monitored and accessed via microcomputer at UW. Measurements were made of wind speed at heights of $0.3 \mathrm{~m}(1 \mathrm{ft})$ and $3 \mathrm{~m}(10 \mathrm{ft})$, wind direction, solar radiant flux, ambient temperature, relative humidity, and rainfall depth, duration, and intensity, and were averaged on an hourly basis. Meteorologic data obtained from this station were used to create the data base to drive the climate in the ESL at UW. In this manner, the climatic conditions which occurred with the lysimeters at the RBOSC site would be repeated at UW in the ESL. Forty-three rainstorms were measured at the field site between September 1987 and March 1989, resulting in $26 \mathrm{~cm}$ (10.4 in) of precipitation in the form of rain and snow.

\subsubsection{Climatic History of ESL Test Embankments}

Processed shale was placed in the two lysimeter cells of the ESL in September 1989. Between September, 1989 and March 1991, forty-three rainstorms were applied for a total depth of $26 \mathrm{~cm}$ (10.4 in) of rain on the processed shale. Runoff and infiltration were not monitored during these storms. Temperature and relative humidity were modeled after those measured at the field site. The purpose of reproducing the RBOSC climatic conditions for an eighteen month period was to verify that the ESL could in fact simulate the field conditions, both in terms of climate and subsurface conditions. Subsurface conditions in the ESL and at the field site were compared on the basis of moisture content and temperature, and their variation with depth.

Five cycles of freezing and thawing were applied between March 1991 and February 1992. The purpose was to determine how long it takes to freeze the spent shale to a given depth and to simulate freeze-thaw activity likely to occur under field conditions.

Following the freeze-thaw cycles, two series of tests were conducted, each consisting of climatic conditions intended to evaluate the hydrologic response of spent shale under severe conditions. Subsurface moisture contents during this period were monitored using neutron moderation and TDR probes. The first test series was designed to study surface runoff-infiltration 
behavior and to develop saturated conditions or conditions for steady-state drainage within the processed oil shale. Hydrologic analysis from the RBOSC, Tract C-a field lysimeters taken from 1988 - 1992, indicated that the greatest flux of water infiltration was during the months of April and May when snowmelt occurs and precipitation is highest. Ambient temperature and relative humidity conditions were modeled (designed) based on the normal mean-monthly temperature and relative humidity for the month of May in Rifle, Colorado, near the Piceance Basin. The normals for May were used because it was assumed that the primary input of water to an embankment or a disposal facility would occur during the April/May period. The climatic model was designed to provide a consistent ambient temperature of $17.1^{\circ} \mathrm{C}$ and $48 \%$ relative humidity. A constant solar flux of 30 $\mathrm{W} / \mathrm{m}^{2}$ was designed for input by the light source for 12.5 hours per day. The constant climatic conditions were designed to help insure consistent evaporation from the processed oil shale. A total of twenty-three rainfall events were applied to the spent shale deposits in the ESL between February 17 and April 15, 1992. Each storm consisted of a rainfall rate of $76 \mathrm{~mm} / \mathrm{hr}$ for approximately 1.5 hours with storms being applied every other day.

The second test series was designed to evaluate potential changes in hydrologic properties of the spent shale when subjected to freeze-thaw conditions close to full saturation. The spent shale embankments were frozen to a depth of $76 \mathrm{~cm}(2.5 \mathrm{ft})$. Based on the earlier freeze tests, it was determined that the freezing front within the processed oil shale would progress at an adequate rate at temperatures less than $-12^{\circ} \mathrm{C}$. The climatic model therefore was designed to produce temperatures between $-18^{\circ}$ and $-12^{\circ} \mathrm{C}$. Relative humidity was designed to be between $30 \%$ and $90 \%$ in psychometric ranges common for the desired ambient temperatures requested. Solar flux of $95 \mathrm{~W} / \mathrm{m}^{2}$ was designed for input by the light source for 8.5 hours per day.

Application of the second testing sequence was initiated in May 1992, however, the sequence was suspended due to failure of a compressor seal on the freezing system after five days of freezing. Repair of the compressor caused a three-week delay and the freezing sequence was 
resumed in August 1992. Monitoring of subsurface temperatures and moisture contents indicated that the embankments were frozen to the required depth of $76 \mathrm{~cm}$ in late March 1993. At this point, a rainfall event was applied to evaluate runoff-infiltration behavior and seepage behavior with a frozen surface. After the rainfall event, the spent shale was allowed to thaw by setting the chamber temperature to $21^{\circ} \mathrm{C}$ at 50 percent relative humidity. Temperature measurements indicated that thawing was complete by May of 1993, at which time a final rainfall event was applied to evaluate changes in runoff-infiltration and seepage caused by freeze-thaw.

\subsection{Results of In Situ Hydraulic Conductivity Tests}

\subsubsection{Vertical Hydraulic Conductivity}

To determine the in situ vertical hydraulic conductivity of spent shale in the ESL, tests were conducted at $30.5 \mathrm{~cm}$ (12 in) depth increments (interface between the lifts) using a double ring infiltrometer, as described in Section 4.3.1. Three tests were conducted at random locations on the surface of Cell 1. Two tests were conducted at each subsequent $30.5 \mathrm{~cm}$ (12 in) depth increment, also at random locations. Results are summarized in Table 4.2. Figure 4.8 shows a plot of vertical hydraulic conductivity versus depth. The dotted lines in the figure indicate the range of conductivity at 95 percent confidence interval. The measured in situ hydraulic conductivities are higher by one to two orders of magnitude than the bench-scale tests. This could be due to cementation and aggregation of spent shale, and also due to the nature of hydration during mixing in large quantities, as discussed later in this section. 
Table 4.2. Vertical Hydraulic Conductivity $\left(\times 10^{-3} \mathrm{~cm} / \mathrm{sec}\right.$ )

\begin{tabular}{|c|c|c|c|c|c|}
\hline \multirow{2}{*}{ Depth (cm) } & \multirow{2}{*}{ Test 1 } & \multirow{2}{*}{ Test 2 } & \multirow{2}{*}{ Average } & \multicolumn{2}{|c|}{ Range } \\
\cline { 5 - 6 } & & & & Lower & Upper \\
\hline 0 & 0.91 & $2.13,1.37$ & 1.49 & 0.77 & 2.20 \\
\hline 30.48 & 0.23 & 0.23 & 0.23 & 0.20 & 0.30 \\
\hline 60.96 & 0.23 & 0.34 & 0.29 & 0.18 & 0.40 \\
\hline 91.44 & 2.28 & 2.06 & 2.17 & 1.96 & 2.39 \\
\hline 121.92 & 2.28 & 1.83 & 2.06 & 1.62 & 2.50 \\
\hline 152.40 & 2.10 & 1.90 & 2.00 & 1.85 & 2.15 \\
\hline 182.88 & 6.84 & 8.20 & 6.00 & 4.10 & 9.00 \\
\hline 213.36 & 6.84 & 5.47 & 6.16 & 5.00 & 7.00 \\
\hline
\end{tabular}

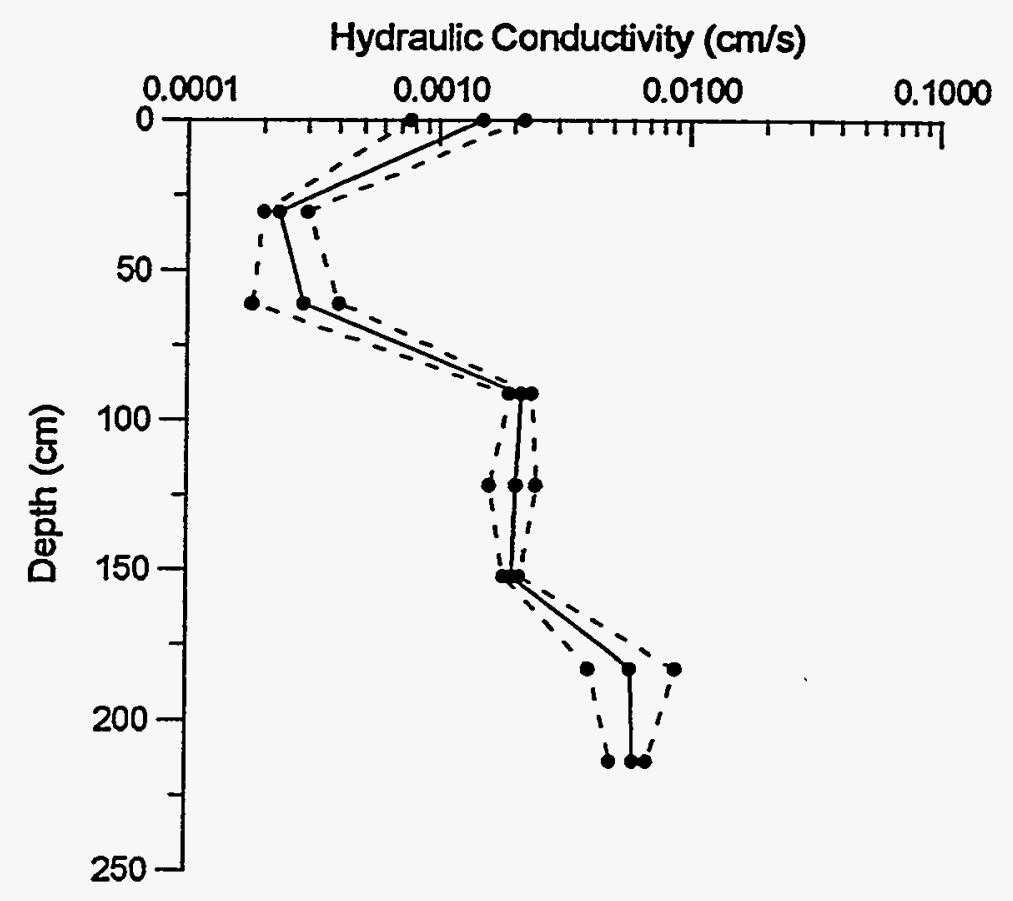

Figure 4.8 Measured vertical hydraulic conductivity versus depth 


\subsubsection{Horizontal Hydraulic Conductivity}

The horizontal hydraulic conductivity of spent shale was evaluated at $0.15 \mathrm{~m}(6 \mathrm{in})$ depth increments using a Guelph permeameter. Four sets of tests were conducted to determine horizontal permeability under different environmental conditions. The first set of tests was conducted before application of the final twenty-three rain events and consisted of one test at each $0.15 \mathrm{~m} \mathrm{(6} \mathrm{in)}$ increment of depth. The second set of tests, conducted after application of 22 rain events also consisted of one test at each $0.15 \mathrm{~m}$ (6 in) depth increment. The third set of tests was conducted when the embankment was at or close to full saturation and consisted of three tests at each 0.15 m (6 in) depth increment. The final set of tests, conducted just before the spent shale was excavated, consisted of five tests at different locations around the perimeter of Cell 1. By the time the final set of tests was conducted, the spent shale had been in the ESL for sixty-nine months.

Results are summarized in Table 4.3. Figure 4.9 shows the horizontal hydraulic conductivity versus depth for all the four sets of tests conducted in the ESL. Figure 4.10 shows in situ hydraulic conductivities measured in the ESL and results of bench-scale tests conducted on samples mixed at an initial water content of 15 percent. In situ hydraulic conductivity is plotted against water contents measured before the tests. Since the Guelph permeameter measures field-saturated hydraulic conductivity, samples were taken from three bore holes after the test to determine the fieldsaturated water content in the spent shale. The average saturated water content was found to be about 29 percent. The bar in Figure 4.10 shows the range of in situ saturated hydraulic conductivity at field-saturated water content. Measured in situ saturated hydraulic conductivities are higher by up to two orders of magnitude than the bench-scale test results. 
Table 4.3 Measured Horlzontal Hydraulic Conductivities ( $\times 10^{-3} \mathrm{~cm} / \mathrm{sec}$ )

\begin{tabular}{|c|c|c|c|c|c|c|c|c|c|c|c|c|}
\hline \multirow{3}{*}{$\begin{array}{l}\text { Depth } \\
\text { (cm) }\end{array}$} & \multirow{3}{*}{$\begin{array}{l}\text { Botoro } \\
\text { Rain }\end{array}$} & \multirow{3}{*}{$\begin{array}{c}2 . \\
\text { After } 22 \\
\text { Rain }\end{array}$} & \multicolumn{5}{|c|}{ 3. At Saturation } & \multicolumn{5}{|c|}{ 4. After Freeze-Thaw } \\
\hline & & & \multirow[t]{2}{*}{ Mean } & \multirow{2}{*}{$\begin{array}{l}\text { Standard } \\
\text { Deviation }\end{array}$} & \multirow[t]{2}{*}{ cov } & \multicolumn{2}{|c|}{ Range } & \multirow[t]{2}{*}{ Mean } & \multirow{2}{*}{$\begin{array}{l}\text { Standard } \\
\text { Doviation }\end{array}$} & \multirow[t]{2}{*}{ cov } & \multicolumn{2}{|c|}{ Range } \\
\hline & & & & & & Lower & Upper & & & & Lower & Upper \\
\hline 15.24 & 0.6703 & 0.1480 & 4.3470 & 0.9141 & 21.03 & 3.3126 & 5.3814 & 3.3604 & 1.9232 & 57.23 & 1.4757 & 5.2452 \\
\hline 30.48 & 3.4607 & 0.9186 & 3.1800 & 1.3958 & 43.89 & 1.2455 & 5.1145 & 3.2419 & 0.8103 & 24.99 & 2.4478 & 4.0360 \\
\hline 45.72 & 0.5080 & 1.0500 & 1.4665 & 1.1773 & 80.28 & 0.1652 & 3.0982 & 2.6255 & 1.5728 & 59.91 & 1.0842 & 4.1669 \\
\hline 60.96 & 7.5410 & 0.1360 & 4.9917 & 4.4683 & 89.52 & 0.0647 & 10.048 & 2.0032 & 2.0535 & 102.51 & 0.0920 & 4.0157 \\
\hline 76.20 & 0.6624 & 0.1360 & 0.7713 & 0.4134 & 53.60 & 0.3035 & 1.2391 & 1.4018 & 1.2870 & 91.81 & 0.2737 & 2.5299 \\
\hline 91.44 & 5.8342 & 5.8670 & 6.6127 & 2.1930 & 33.16 & 4.1310 & 9.0943 & 1.1954 & 1.5176 & 43.30 & 0.6882 & 1.7026 \\
\hline 106.68 & 0.3146 & 0.5270 & 0.7683 & 1.0350 & 134.71 & 0.4029 & 1.9396 & 0.5334 & 0.3033 & 56.86 & 0.2362 & 0.8307 \\
\hline 121.92 & - & 5.3043 & 0.4367 & 0.2309 & 52.88 & 0.1754 & 0.6980 & 0.5586 & 0.3806 & 68.14 & 0.1856 & 0.9316 \\
\hline 137.16 & 1.1142 & 2.2225 & 0.2640 & 0.0042 & 1.61 & 0.2581 & 0.2699 & 0.6994 & 0.9621 & 137.58 & 0.2436 & 1.6423 \\
\hline 152.40 & 3.3200 & 1.3040 & 1.2587 & 0.2865 & 22.76 & 0.9344 & $\cdot 1.5829$ & 0.6282 & 0.4453 & 70.88 & 0.1918 & 1.0646 \\
\hline 167.64 & 2.0570 & 2.5500 & 1.0890 & 0.3748 & 34.41 & 0.5696 & 1.6084 & 0.6006 & 0.1916 & 31.91 & 0.3837 & 0.8174 \\
\hline 82.88 & 1.9500 & 0.9180 & 0.7960 & 0.1549 & 19.46 & 0.6207 & 0.9713 & 0.5255 & 0.1783 & 33.93 & 0.3237 & 0.7273 \\
\hline 197.12 & 0.4670 & 1.7030 & 0.4375 & 0.1817 & 41.54 & 0.1856 & 0.6894 & 0.4939 & 0.3408 & 69.00 & 0.1083 & 0.8795 \\
\hline 213.36 & 1.5000 & 2.3600 & 2.8673 & 0.4597 & 16.03 & 2.3471 & 3.3875 & 0.5304 & 0.2770 & 52.23 & 0.2589 & 0.8019 \\
\hline 228.60 & 1.0900 & 0.9190 & 2.8755 & 0.3543 & 12.32 & 2.3845 & 3.3665 & & & & & \\
\hline
\end{tabular}

$-86-$ 


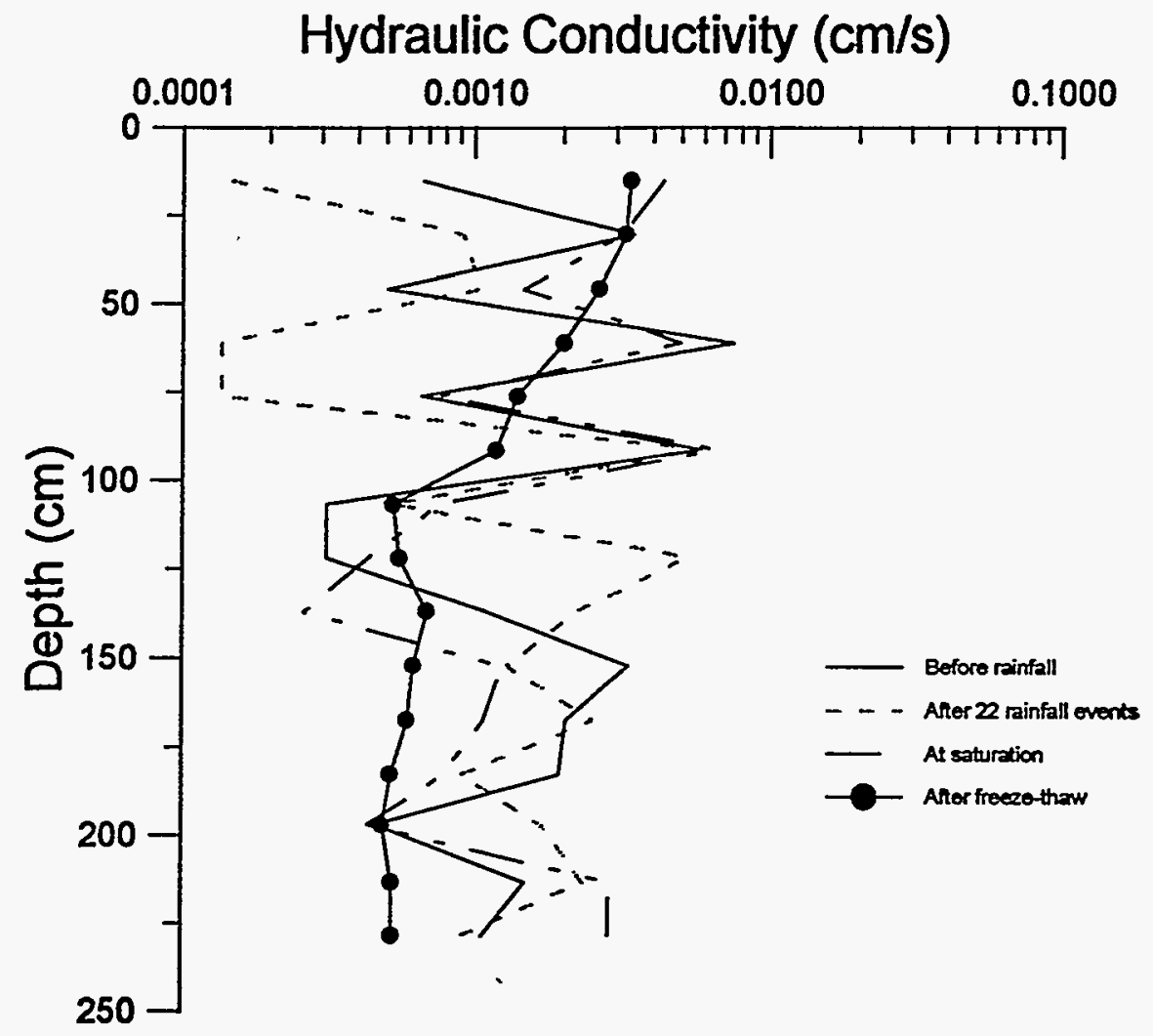

Figure 4.9. Measured horizontal hydraulic conductivity versus depth 


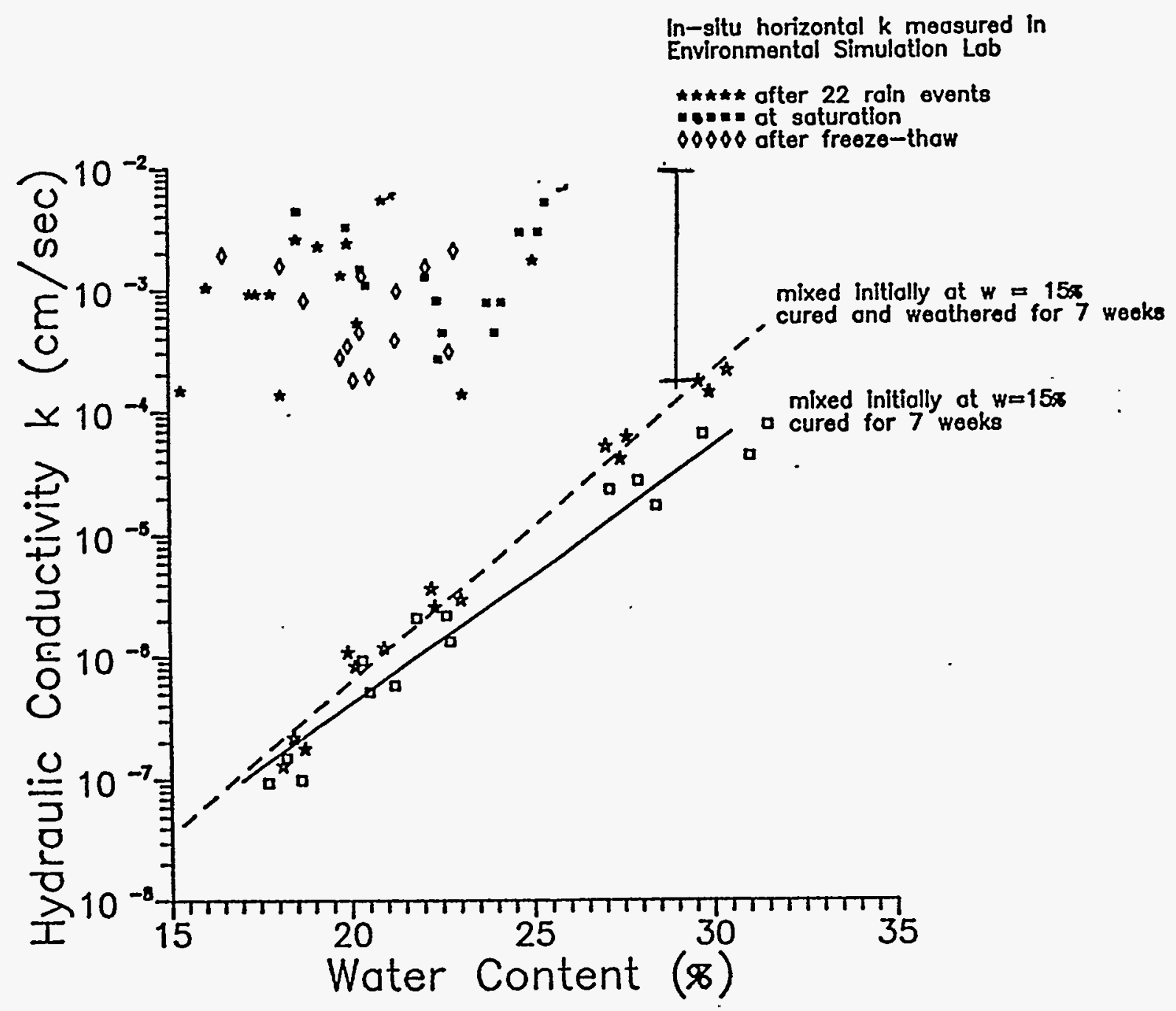

Figure 4.10. Comparison of measured in situ hydraulic conductivity in the ESL to bench-scale tests 


\subsubsection{Discussion of In Situ Hydraulic Conductivity}

Significantly higher in situ hydraulic conductivities (k) were observed from in situ measurements than those measured in bench-scale tests. This difference can be understood in terms of: (1) differences in mixing and compaction procedures between large-scale placement and those for bench-scale specimens and (2) the cementing characteristics of spent shale. When specimens are prepared in the laboratory, a relatively small amount (approximately 300 grams) of spent shale is mixed with water in a bowl. Water is distributed uniformly throughout the material before it is compacted in a mold. Upon curing, this procedure yields specimens that are uniformly cemented throughout. The texture of these specimens is that of a hard, dense, material very similar to concrete. Figure 4.11 shows laboratory-prepared specimens, which have been subjected to wetdry weathering, that illustrate this texture. As shown earlier, increasing water content results in greater cementation and lower hydraulic conductivities.

Spent shale placed in the ESL was mixed to a water content of 15 percent in the rotating drum of a ready-mix concrete truck. It was observed during placement that a portion of the moist mix consisted of relatively large aggregates of spent shale particles (up to several $\mathrm{cm}$ in diameter) that were moist on the outside but dry inside. Upon curing, these aggregated particles consisted of a cemented outer shell with $d r y$, unhydrated spent shale inside. The outer shell could barely be broken between the fingers. These particles give the compacted spent shale a nonuniform texture, in which some zones consist of a highly cemented matrix with inclusions of aggregated particles, while other zones consist largely of aggregated particles with the texture of a lightly-cemented sandy gravel or gravelly sand. While removing spent shale from the borings made for the Guelph permeameter tests and during excavation of the embankments, it was observed that the spent shale encased in the aggregations had also become hydrated and cemented, producing particles of very hard spent shale ranging in diameter from 0.05 to $50.0 \mathrm{~mm}$ (Figure 4.12). The effective grain size distribution of the spent shale in the ESL embankments was more coarse and less cemented than 
.

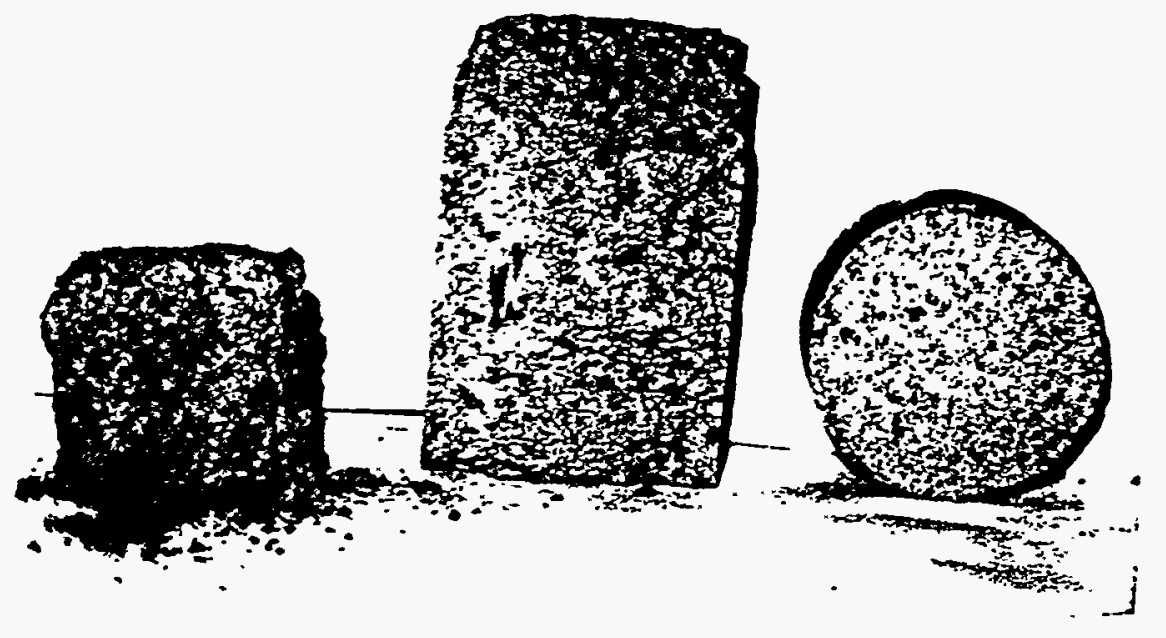

Figure 4.11 Laboratory prepared specimens.

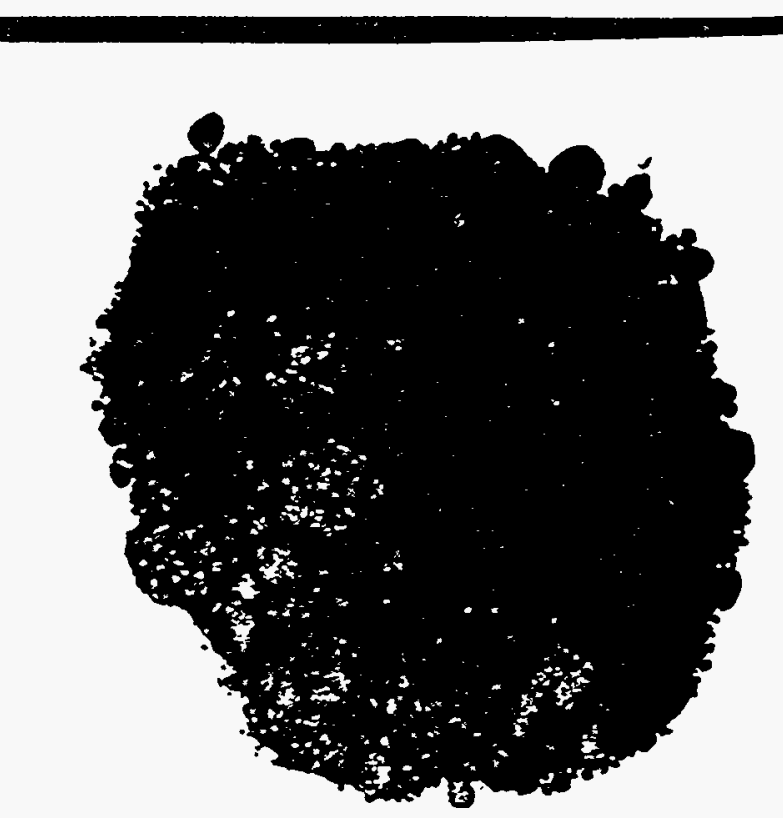

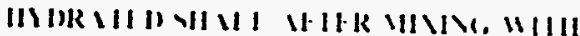
"II-k IVIII IIII kI !)

Figure 4.12 Aggregated particles in sample from the ESL test embankment 
specimens prepared at the same water content for bench-scale testing. It is this difference in texture that results in higher conductivities in the embankments.

The observation described above has major implications regarding estimation of hydraulic conductivity for commercial-scale waste embankments. Movement of water through spent shale waste piles could be much higher than would be predicted using values of $k$ measured on benchscale specimens. Estimation of $k$ must account for effects of placement and compaction methods and cementation, and how these factors influence the texture and, therefore, the hydraulic conductivity of spent shale.

\subsubsection{Changes in Grain Size Distribution}

One of the factors that controls texture and hydraulic conductivity of granular materials is grain size distribution. It is noted above that cementation effectively changes the grain size distribution of hydrated spent shale and that the changes depend on mixing and compaction procedures. One indication of the range of change that is possible would be to compare the grain size distribution of unhydrated spent shale to that of samples removed from the ESL test embankments. Turner and Rothwell (1991) presented an average grain-size distribution curve for the unhydrated spent shale that was placed in the ESL. This curve is shown in Figure 4.13 along with grain size distribution curves of spent shale removed from the ESL. The two curves represented by dashed lines show the range of grain size distributions for the embankment material. These results clearly show larger percentages of fine particles in the unhydrated spent shale, especially for particle sizes less than $1 \mathrm{~mm}$. This is most likely caused by cementation, in which the finer materials undergo chemical reactions that produce cements that surround the silt and sand-size particles, decreasing the fines and increasing the percentage of coarse-grained particles. Formation of the large, aggregated particles described above also decreases the percent passing at the larger particle size end of the grain size distribution curve, as can be observed in Figure 4.13. 


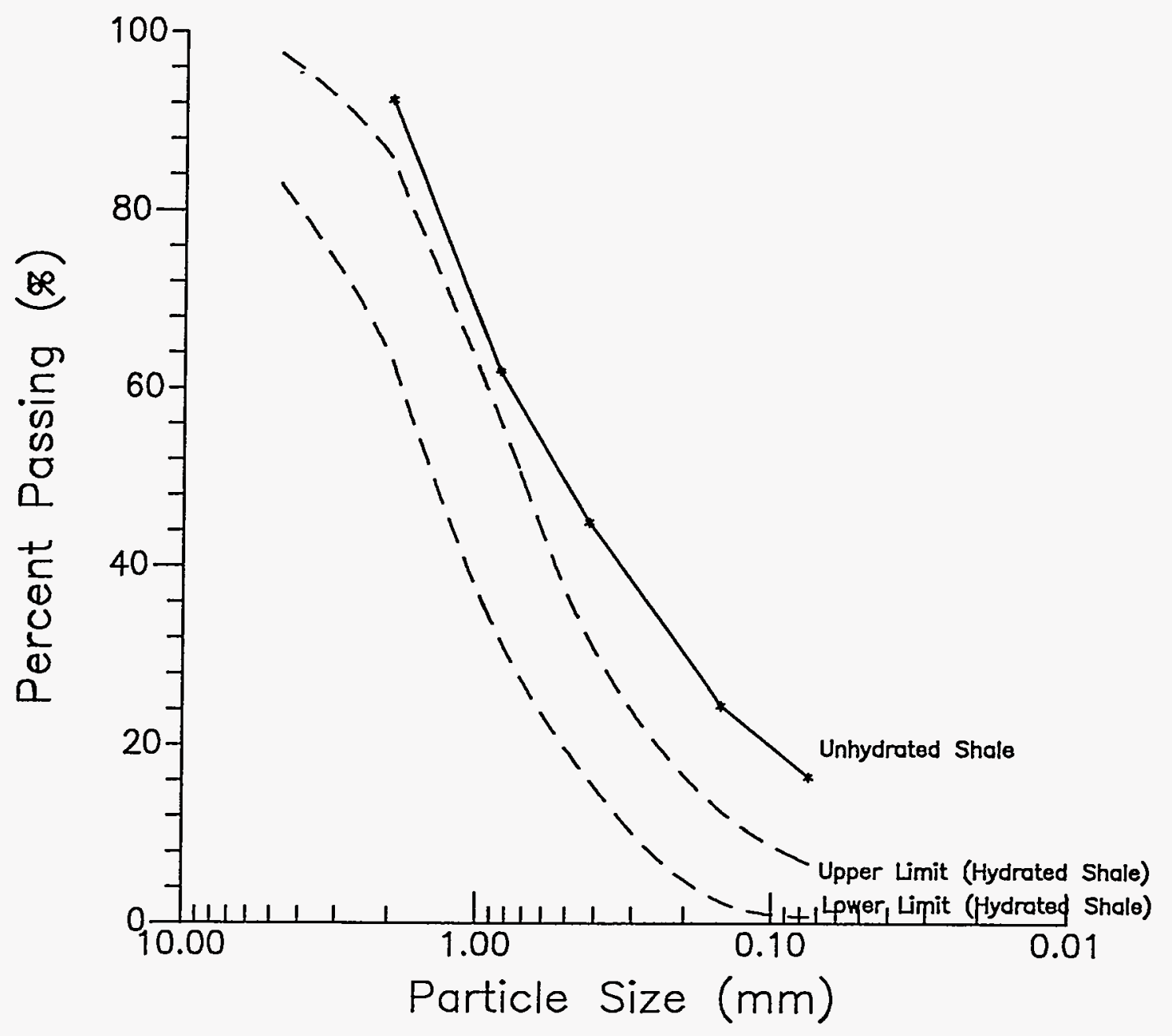

Figure 4.13. Comparison of grain-size distribution curves, hydrated and unhydrated spent shale 
The influence of grain size distribution changes on hydraulic conductivity can be approximated quantitatively by considering empirical relationships between grain size distribution parameters and $k$. One widely-cited correlation that is applicable to dense or compacted sands (Sherard et al.1984) is given by:

$$
k=0.35\left(D_{15}\right)^{2}
$$

where $D_{15}$ is the particle size corresponding to 15 percent passing, expressed in millimeters, and $k$ is expressed in $\mathrm{cm} / \mathrm{sec}$. This yields an estimate of $k=1.6 \times 10^{-3} \mathrm{~cm} / \mathrm{sec}$ for unhydrated spent shale based on grain size distribution, and an estimate of $k=12.6$ to $56.0 \times 10^{-3} \mathrm{~cm} / \mathrm{sec}$ for spent shale removed from the ESL embankments. This rough approximation indicates that grain size distribution changes alone may account for approximately a one-order of magnitude increase in spent shale hydraulic conductivity. This does not account for changes in pore sizes and pore shapes that may occur due to cementation, but does account in part for the higher values of $k$ measured in situ compared to bench-scale measurements.

\subsubsection{In Situ Spatial and Temporal Variations}

Figure 4.9 and Table 4.3 indicate that in situ hydraulic conductivity tests conducted before application of rain events was higher in the upper layers compared to lower layers. This may be due to weathering and evaporation in the upper layers causing micro cracks in the spent shale. However, the hydraulic conductivities appear to be more consistent at the lower layers compared to upper layers. A possible reason for this behavior could be uniform cementation due to high overburden pressure at lower depths.

Tests conducted after twenty-two rain events indicate a lower hydraulic conductivity in the upper layers but do not show a significant change beyond $91.4 \mathrm{~cm}(3 \mathrm{ft})$ depth. This may be due to 
hardening of spent shale in the upper layers as more water is available for further cementation.

At or close to full saturation condition, a higher hydraulic conductivity was observed in the upper layers of spent shale indicating an increase in hydraulic conductivity with increase in water content. However, in the lower layers the hydraulic conductivity decreased by an order of magnitude. This could be due to hydration of unhydrated spent shale at the lower depths with downward movement of water.

Tests conducted after a cycle of freeze-thaw did not indicate a significant change in hydraulic conductivity compared to that at or close to full saturation.

\subsection{Hydraulic Conductivity from Back Calculation Method}

This method, described in Section 3, is based on one-dimensional Darcy's law and observed changes in water content in the test embankment. To back calculate the hydraulic conductivity of spent shale from soil-moisture characteristic curves and in situ measured water contents, it was necessary to estimate two hydrologic parameters: 1) volumetric flux of water, and 2) hydraulic gradient. Volumetric flux was estimated as the change in planimetric area between water content curves at two sampling times over a specified depth interval. Total hydraulic head was estimated from the soil suction, determined from the soil-moisture characteristic curve using the measured in situ water content, and elevation head. Then using one dimensional Darcy's law for flow of water through porous media, hydraulic conductivity (k) was calculated as the ratio of volumetric flux to hydraulic gradient.

$$
k=q / i
$$

Where: $\quad q=$ volumetric flux $\left(\mathrm{cm}^{3} / \mathrm{cm}^{2} / \mathrm{sec}\right)$

$$
i=\text { hydraulic gradient }
$$

Capillary suction was obtained from the soil-moisture characteristic relationship of the spent shale, which was established using a 2-bar pressure plate apparatus. Figure 4.14 shows the results 
in terms of water content versus capillary suction.

At the RBOSC field site, in situ moisture contents were monitored using TDR probes. The time intervals over which changes in moisture content were measured ranged from 14 days to 154 days at the field site. During time intervals of this length, moisture content may have changed several times, resulting in several changes in hydraulic gradient. The assumption that hydraulic gradient is approximately constant over the time interval used in the computations most likely was violated, which raises doubts about the reliability of the results based on the field measurements. Results of back-calculation of hydraulic conductivity from the RBOSC field embankments are presented in Tables 4.4 through 4.7. There is too much scatter in the data to make definitive conclusions regarding the relationship between hydraulic conductivity and water content. Most likely, this is due to the long time intervals over which changes in moisture content were measured.

During application of the twenty-three rain events applied between February and April, 1992, in the ESL, an opportunity was provided to apply the back-calculation technique and to compare it against other methods for computing hydraulic conductivity, such as measurements made with the Guelph permeameter and double ring infiltrometer. In situ water contents were measured using neutron moderation. Measurements were made at two locations in Cell 1 at twelve depths. The water content measurements were made immediately before and after each rainstorm. Figure 4.15 shows a typical plot of measured water content versus depth before and after a rain event. Results of this analysis for calculation of hydraulic conductivity are tabulated in Table 4.8 for the selected rain events. Figure 4.16 shows a plot of hydraulic conductivity versus average water content over the time and depth interval used in the calculations. The general trend of increasing conductivity with increasing water content is consistent with theoretical models for hydraulic conductivity, which predict hydraulic conductivity increasing in proportion to degree of saturation cubed.

The computed values of hydraulic conductivity also are within the range of values obtained from Guelph permeameter tests and double ring infiltrometer tests, indicating that this method may 


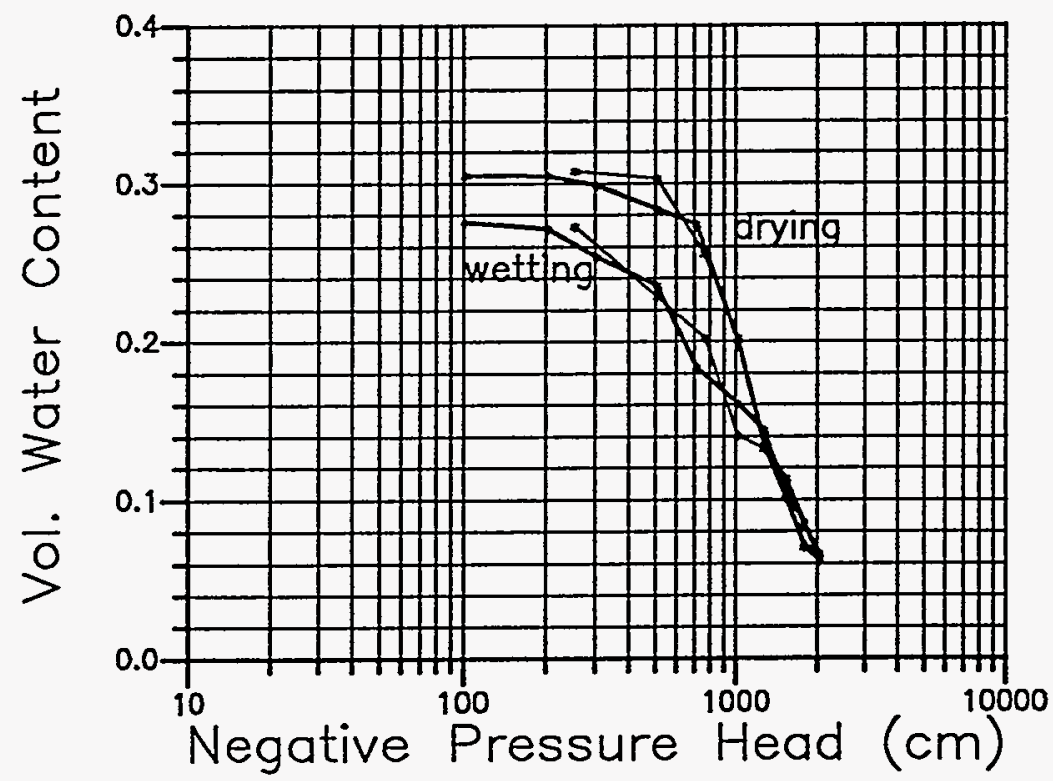

Figure 4.14. Capillary pressure vs water content using a 2-bar pressure plate apparatus

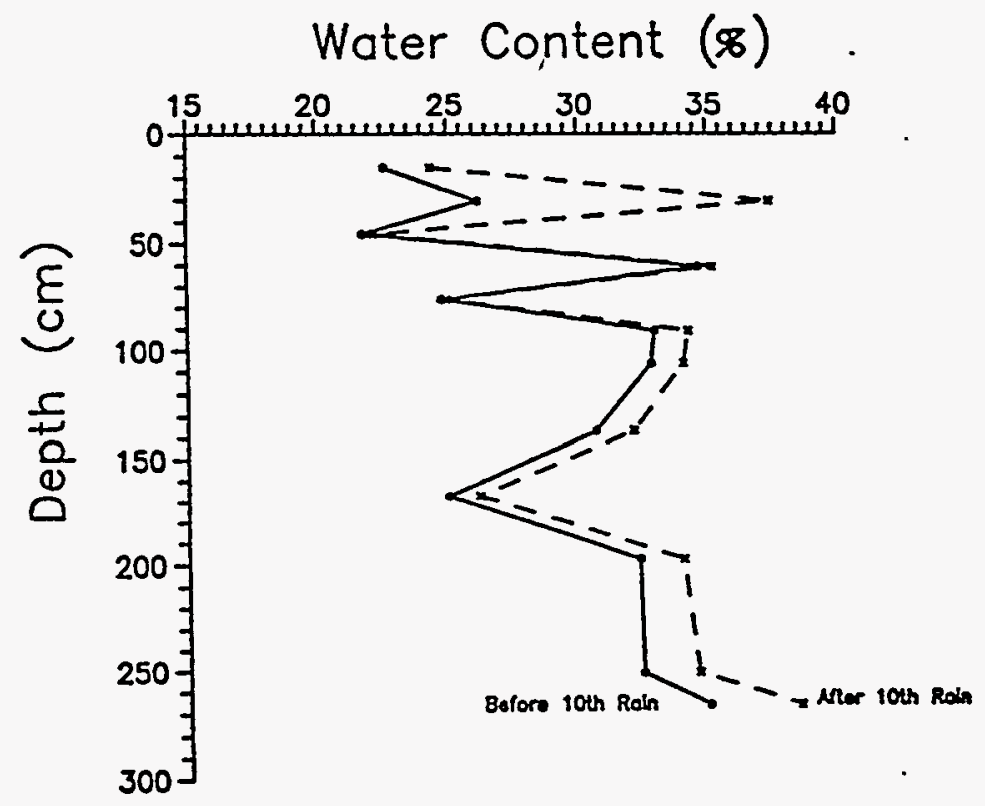

Figure 4.15. Typical plot of measured water content vs depth 
Table 4.4. Hydrologic Data Analyses for Hydraulic Conductivity, Cell 1 Replication 1, at RBOSC

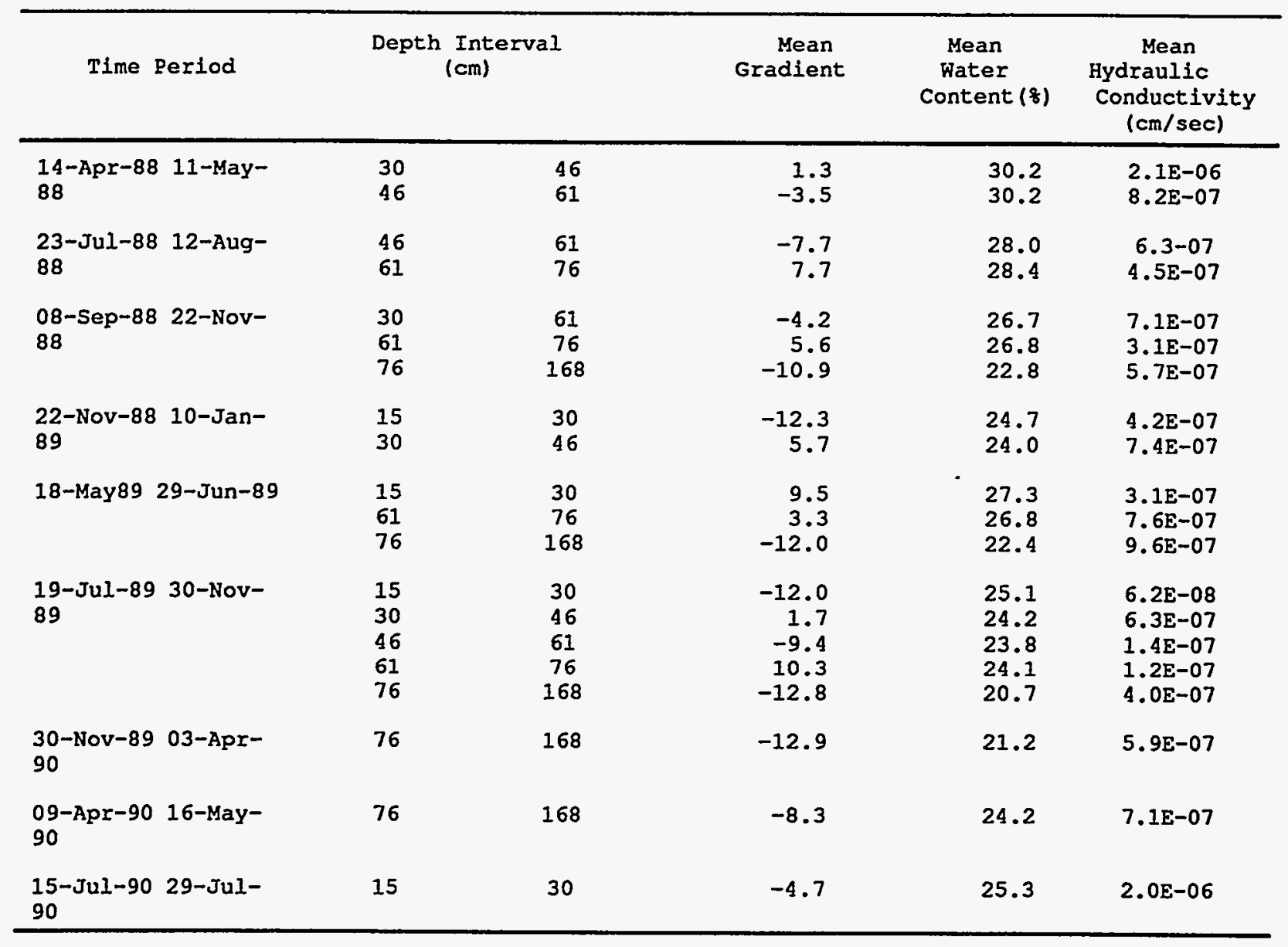


Table 4.5. Hydrologic Data Analyses for Hydraulic Conductivity, Cell 1 Replication 2, at RBOSC

\begin{tabular}{|c|c|c|c|c|c|}
\hline Time Period & Depth & $\begin{array}{l}\text { Interval } \\
\text { (cm) }\end{array}$ & $\begin{array}{l}\text { Mean } \\
\text { Hydraulic } \\
\text { Gradient }\end{array}$ & $\begin{array}{c}\text { Mean } \\
\text { Water } \\
\text { Content } \\
(q)\end{array}$ & $\begin{array}{c}\text { Mean } \\
\text { Hydraulic } \\
\text { Conductivity } \\
(\mathrm{cm} / \mathrm{sec})\end{array}$ \\
\hline 23-Jul-88 12-Aug-88 & $\begin{array}{c}76 \\
168\end{array}$ & $\begin{array}{l}168 \\
259\end{array}$ & $\begin{array}{l}-1.4 \\
-3.3\end{array}$ & $\begin{array}{l}28.8 \\
26.5\end{array}$ & $\begin{array}{l}1.0 \mathrm{E}-05 \\
1.3 \mathrm{E}-06\end{array}$ \\
\hline 12-Aug-88 05-Sep-88 & 76 & 168 & -0.8 & 28.0 & $7.5 \mathrm{E}-06$ \\
\hline 05-Sep-88 22-Nov-88 & $\begin{array}{l}46 \\
76\end{array}$ & $\begin{array}{c}76 \\
168\end{array}$ & $\begin{array}{l}-9.3 \\
-0.2\end{array}$ & $\begin{array}{l}30.1 \\
27.2\end{array}$ & $\begin{array}{l}3.8 \mathrm{E}-07 \\
1.9 \mathrm{E}-05\end{array}$ \\
\hline 31-Mar-89 25-Apr-89 & $\begin{array}{c}76 \\
168\end{array}$ & $\begin{array}{l}168 \\
259\end{array}$ & $\begin{array}{l}-1.4 \\
-2.8\end{array}$ & $\begin{array}{l}29.3 \\
27.2\end{array}$ & $\begin{array}{l}6.9 E-06 \\
3.1 E-06\end{array}$ \\
\hline 25-Аpr-89 18-Мау-89 & $\begin{array}{c}76 \\
168\end{array}$ & $\begin{array}{l}768 \\
259\end{array}$ & $\begin{array}{l}-1.3 \\
-2.9\end{array}$ & $\begin{array}{l}29.0 \\
27.6\end{array}$ & $\begin{array}{l}4.2 E-06 \\
1.5 E-06\end{array}$ \\
\hline 18-May-89 29-Jun-89 & $\begin{array}{c}15 \\
30 \\
46 \\
76 \\
168\end{array}$ & $\begin{array}{c}30 \\
46 \\
76 \\
168 \\
259\end{array}$ & $\begin{array}{r}3.6 \\
21.1 \\
-6.1 \\
-0.8 \\
-3.4\end{array}$ & $\begin{array}{l}24.0 \\
28.2 \\
29.8 \\
27.9 \\
26.2\end{array}$ & $\begin{array}{l}3.8 E-07 \\
8.3 E-08 \\
8.7 E-07 \\
2.1 E-05 \\
2.4 E-06\end{array}$ \\
\hline 29-Jun-89 30-Nov-89 & $\begin{array}{l}15 \\
30 \\
46 \\
76\end{array}$ & $\begin{array}{c}30 \\
46 \\
76 \\
168\end{array}$ & $\begin{array}{r}-2.4 \\
30.4 \\
-10.0 \\
0.5\end{array}$ & $\begin{array}{l}21.9 \\
25.6 \\
26.8 \\
25.2\end{array}$ & $\begin{array}{l}3.2 \mathrm{E}-07 \\
3.4 \mathrm{E}-08 \\
2.0 \mathrm{E}-07 \\
8.6 \mathrm{E}-06\end{array}$ \\
\hline 03-Apr-90 16-Маy-90 & $\begin{array}{l}15 \\
46 \\
76\end{array}$ & $\begin{array}{c}30 \\
76 \\
168\end{array}$ & $\begin{array}{l}23.7 \\
-7.1 \\
-0.6\end{array}$ & $\begin{array}{l}20.6 \\
25.5 \\
26.5\end{array}$ & $\begin{array}{l}7.9 \mathrm{E}-08 \\
5.6 \mathrm{E}-07 \\
7.1 \mathrm{E}-06\end{array}$ \\
\hline 16-May-90 29-Jun-90 & $\begin{array}{l}46 \\
61\end{array}$ & $\begin{array}{l}61 \\
73\end{array}$ & $\begin{array}{r}-5.2 \\
-15.0\end{array}$ & $\begin{array}{l}30.3 \\
27.6\end{array}$ & $\begin{array}{l}6.8 \mathrm{E}-07 \\
1.3 \mathrm{E}-07\end{array}$ \\
\hline 29-Jun-90 18-Jul-90 & $\begin{array}{l}15 \\
46 \\
76\end{array}$ & $\begin{array}{c}30 \\
61 \\
168\end{array}$ & $\begin{array}{r}-0.3 \\
-3.2 \\
0.2\end{array}$ & $\begin{array}{l}21.0 \\
31.7 \\
26.3\end{array}$ & $\begin{array}{l}1.7 \mathrm{E}-05 \\
2.5 \mathrm{E}-06 \\
1.9 \mathrm{E}-04\end{array}$ \\
\hline 18-Jul-90 29-Jul-90 & $\begin{array}{c}15 \\
168\end{array}$ & $\begin{array}{c}30 \\
259\end{array}$ & $\begin{array}{l}48.9 \\
-0.4\end{array}$ & $\begin{array}{l}20.0 \\
29.1\end{array}$ & $\begin{array}{l}3.4 \mathrm{E}-07 \\
9.9 \mathrm{E}-05\end{array}$ \\
\hline
\end{tabular}


Table 4.6. Hydrologic Data Analyses for Hydraulic Conductivity, Cell 2 Replication 1, at RBOSC

\begin{tabular}{|c|c|c|c|c|c|c|}
\hline Time & Period & Depth & $\begin{array}{l}\text { Interval } \\
\text { (cm) }\end{array}$ & $\begin{array}{c}\text { Mean } \\
\text { Hydraulic } \\
\text { Gradient }\end{array}$ & $\begin{array}{l}\text { Mean Water } \\
\text { Content }(t)\end{array}$ & $\begin{array}{c}\text { Mean } \\
\text { Hydraulic } \\
\text { Conductivity } \\
(\mathrm{cm} / \mathrm{sec})\end{array}$ \\
\hline 14-Apr-88 & $11-$ May-88 & $\begin{array}{l}168 \\
259\end{array}$ & $\begin{array}{l}259 \\
290\end{array}$ & $\begin{array}{r}-2.3 \\
-12.8\end{array}$ & $\begin{array}{l}21.2 \\
19.3\end{array}$ & $\begin{array}{l}3.5 \mathrm{E}-06 \\
2.9 \mathrm{E}-07\end{array}$ \\
\hline $05-$ Sep-88 & $22-$ Nov-88 & $\begin{array}{c}91 \\
107 \\
168 \\
259\end{array}$ & $\begin{array}{l}107 \\
138 \\
259 \\
290\end{array}$ & $\begin{array}{r}-14.9 \\
7.0 \\
-4.0 \\
-9.5\end{array}$ & $\begin{array}{l}19.7 \\
21.1 \\
21.8 \\
19.4\end{array}$ & $\begin{array}{l}6.9 \mathrm{E}-08 \\
6.2 \mathrm{E}-07 \\
6.6 \mathrm{E}-07 \\
1.5 \mathrm{E}-07\end{array}$ \\
\hline 10-Jan-89 & $31-\mathrm{Mar}-89$ & $\begin{array}{c}91 \\
107\end{array}$ & $\begin{array}{l}107 \\
168\end{array}$ & $\begin{array}{r}-2.4 \\
5.8\end{array}$ & $\begin{array}{l}18.6 \\
20.2\end{array}$ & $\begin{array}{l}2.2 E-07 \\
3.9 E-07\end{array}$ \\
\hline 25-Apr-89 & 18-May-89 & $\begin{array}{c}91 \\
107\end{array}$ & $\begin{array}{l}107 \\
168\end{array}$ & $\begin{array}{r}-4.9 \\
4.8\end{array}$ & $\begin{array}{l}19.1 \\
20.3\end{array}$ & $\begin{array}{l}6.4 E-07 \\
2.1 E-06\end{array}$ \\
\hline 18-May-89 & 29-Jun-89 & $\begin{array}{c}91 \\
107 \\
168 \\
259\end{array}$ & $\begin{array}{l}107 \\
168 \\
259 \\
290\end{array}$ & $\begin{array}{r}-5.4 \\
3.1 \\
-3.0 \\
-7.3\end{array}$ & $\begin{array}{l}19.2 \\
20.0 \\
20.2 \\
18.8\end{array}$ & $\begin{array}{l}2.8 E-07 \\
2.6 E-06 \\
2.7 E-06 \\
4.5 E-07\end{array}$ \\
\hline 29-Jun-90 & 18-Ju1-90 & 76 & 91 & 75.2 & 15.2 & $7.7 E-08$ \\
\hline
\end{tabular}

Table 4.7. Hydrologic Data Analyses for Hydraulic Conductivity, Cell 2 Replication 2, at RBOSC

\begin{tabular}{cccccc}
\hline Time Period & Depth Interval & $\begin{array}{c}\text { Mean } \\
(\mathrm{cm})\end{array}$ & $\begin{array}{c}\text { Hydraulic } \\
\text { Gradient }\end{array}$ & $\begin{array}{c}\text { Mean Water } \\
\text { Content (8) }\end{array}$ & $\begin{array}{c}\text { Hydraulic } \\
\text { Conductivity } \\
(\mathrm{cm} / \mathrm{sec})\end{array}$ \\
\hline 29-Jun-90 18-Jul-90 & 107 & 168 & -1.9 & 16.9 & $9.2 \mathrm{E}-06$ \\
\hline
\end{tabular}


Table 4.8. Analysis of In situ Hydraulic Conductivity, Coll 1 of ESL

\begin{tabular}{|c|c|c|c|c|c|c|c|c|c|c|c|c|c|}
\hline \multicolumn{14}{|c|}{ CELLI TUBEA } \\
\hline Raln & Deoth & $w 1(\%)$ & $w_{2}(\%)$ & Volume by & Total Head & Total Head & Gradlent & Gradlent & Average & $\sqrt{\text { Duration }}$ & $q=$ & \multicolumn{2}{|l|}{ Permeabillty } \\
\hline & $(\mathrm{cm})$ & before & after & (Planlmetry) & Before Rain & $\begin{array}{l}\text { After Raln } \\
\end{array}$ & before & atter & Gradient & of rain & Vol/mime & $k$ & \\
\hline & & raln & rain & (cm) & (cm) & (cm) & rain & rain & (1) & (hr) & $(\mathrm{cm} / \mathrm{sec})$ & $(\mathrm{cm} / \mathrm{sec})$ & \\
\hline \multirow[t]{2}{*}{5} & 91.44 & 32.99 & 35.34 & 80.92 & 229.28 & 134.28 & 15.98 & 15.76 & 15.87 & 1.29 & 0.02 & $1.10 E-03$ & \\
\hline & 137.16 & 21.97 & 22.43 & & 960.00 & 855.00 & & & & & & & \\
\hline & & & & & & & & & & & & & \\
\hline \multirow[t]{2}{*}{6} & 106.68 & 30.75 & 31.67 & 93.88 & 299.04 & 274.04 & 11.09 & 9.45 & 10.27 & 1.18 & 0.02 & $2.15 E-03$ & \\
\hline & 167.64 & 21.57 & 22.43 & & 975.00 & 850.00 & & & & & & & \\
\hline \multirow[t]{3}{*}{7} & 137.16 & 28.15 & 29.98 & 109.27 & 459.04 & 339.04 & 20.19 & 13.30 & 16.75 & 1.40 & 0.02 & $1.30 E-03$ & \\
\hline & 198.12 & 17.64 & 20.44 & & 1690.00 & 1150.00 & & & & & & & \\
\hline & & & & & & & & & & & & & \\
\hline \multirow[t]{2}{*}{10} & 198.12 & 22.43 & 22.94 & 175.49 & 796.66 & 746.66 & -8.37 & -11.84 & -10.11 & 1.27 & 0.04 & $-3.80 E-03$ & \\
\hline & 251.46 & 31.21 & 37.28 & & 350.00 & 115.00 & & & & & & & \\
\hline & & & & & & & & & & & & & \\
\hline \multirow[t]{2}{*}{12} & 91.44 & 34.52 & 36.00 & 47.70 & 164.28 & 104.28 & 5.92 & 6.47 & 6.19 & 1.32 & 0.01 & $1.62 E-03$ & \\
\hline & 137.16 & 29.12 & 29.98 & & 435.00 & 400.00 & & & & & & & \\
\hline \multirow[t]{3}{*}{13} & 167.64 & 23.66 & 24.73 & 33.53 & 694.52 & 619.52 & 5.10 & 3.79 & $\overline{4.44}$ & 1.32 & 0.01 & $1.59 E-03$ & \\
\hline & 198.12 & 22.48 & 23.61 & & 850.00 & 735.00 & & & & & & & \\
\hline & & & & & & & & & & & & & \\
\hline \multirow[t]{3}{*}{14} & 91.44 & 34.68 & 37.31 & 107.82 & 154.28 & 69.28 & 6.25 & 6.03 & 6.14 & 1.56 & 0.02 & $3.12 E-03$ & \\
\hline & 137.16 & 28.96 & 31.39 & & 440.00 & 345.00 & & & & & & & \\
\hline & & & & & & & & & & & & & \\
\hline \multirow[t]{2}{*}{16} & 91.44 & 34.58 & 35.44 & 42.37 & 164.28 & 134.28 & 5.48 & 5.48 & 5.48 & 1.32 & 0.01 & $1.62 E-03$ & \\
\hline & 137.16 & 29.42 & 30.33 & & 415.00 & 385.00 & & & & & & & \\
\hline \multirow[t]{2}{*}{18} & 91.44 & 33.87 & 35.89 & 55.55 & 194.28 & 114.28 & 5.37 & 6.03 & 5.70 & 1.43 & 0.01 & $1.89 E-03$ & \\
\hline & 137.16 & 28.96 & 30.23 & & 440.00 & 390.00 & & & & & & & \\
\hline & & & & & & & & & & & & & \\
\hline \multirow[t]{3}{*}{20} & 91.44 & 33.72 & 36.45 & 68.20 & 199.28 & 101.28 & 5.70 & 6.64 & 6.17 & 1.59 & 0.01 & $1.93 E-03$ & \\
\hline & 137.16 & 28.25 & 29.77 & & 460.00 & 405.00 & & & & & & & \\
\hline & & & & & & & & & & & & & \\
\hline \multirow[t]{2}{*}{22} & 91.44 & 34.83 & 37.06 & 82.52 & 149.28 & 79.28 & 6.48 & 5.92 & 5.70 & 1.47 & 0.02 & $2.73 E-03$ & \\
\hline & 137.16 & 29.92 & 31.19 & & 400.00 & 350.00 & & & & & & & \\
\hline
\end{tabular}

$-100-$ 
Table 4.8 (cont)

\begin{tabular}{|c|c|c|c|c|c|c|c|c|c|c|c|c|}
\hline CELLI TOWER & & & & & & & & & & & \\
\hline
\end{tabular}

$-101-$ 


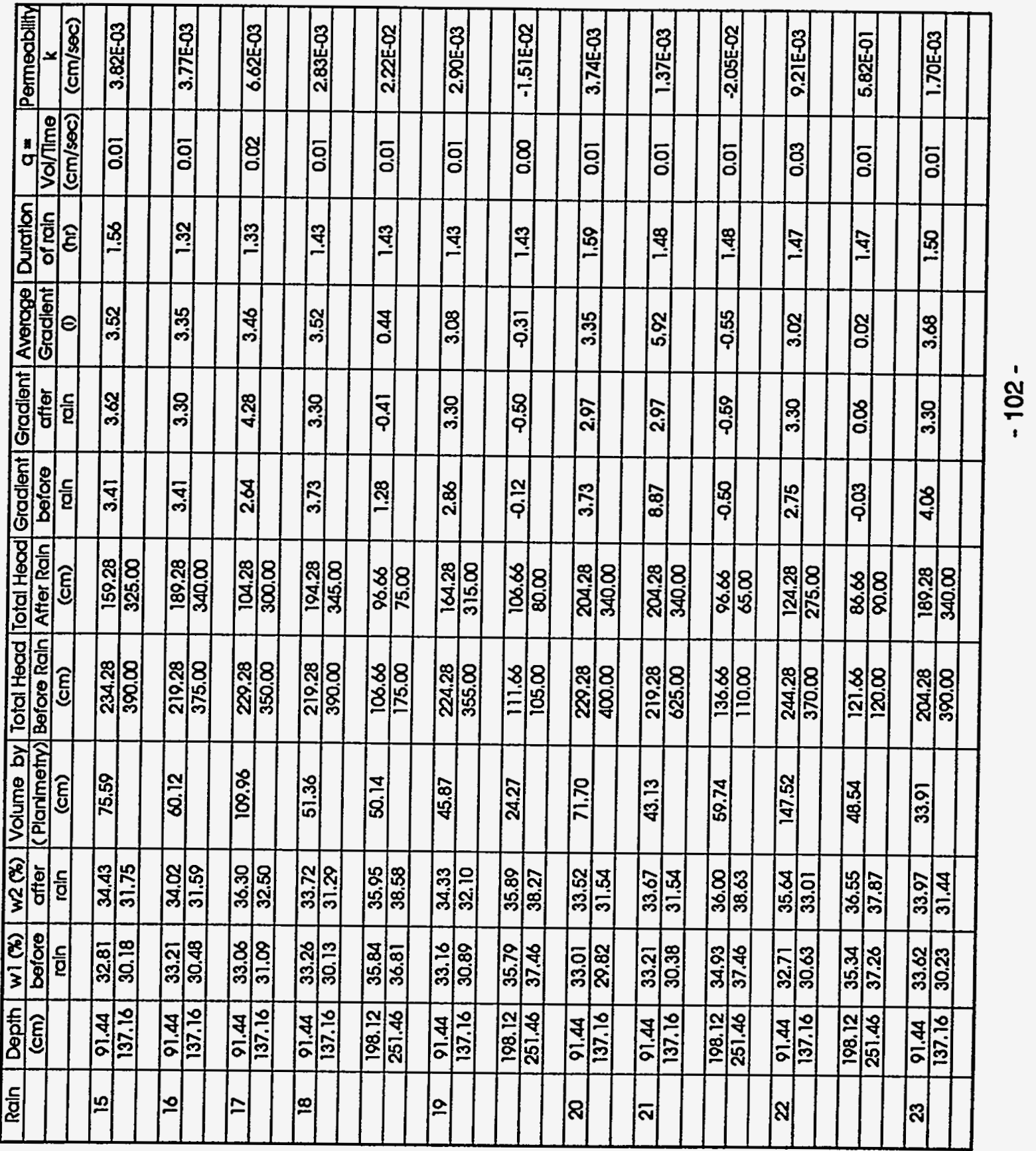




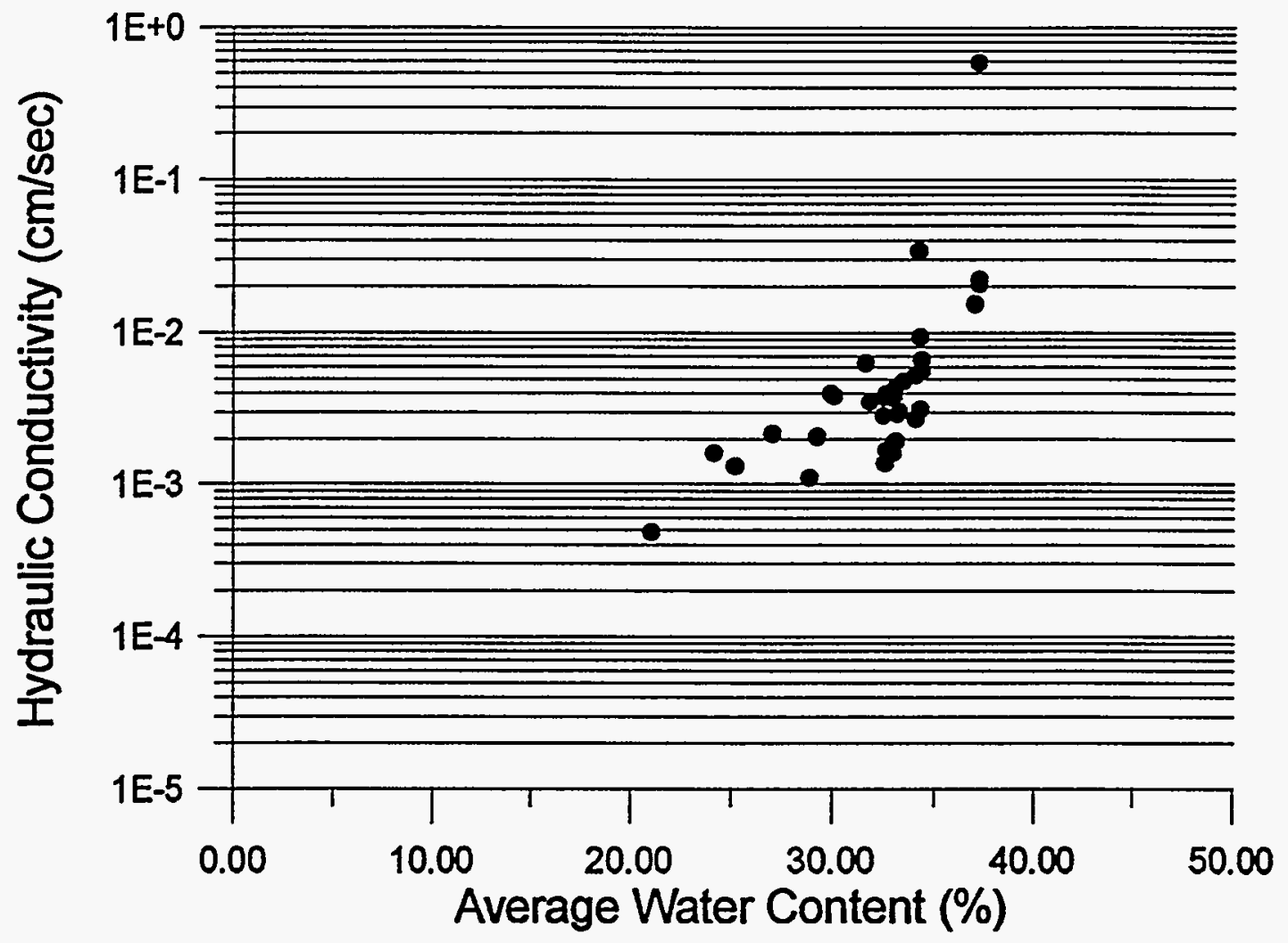

Figure 4.16. Hydraulic conductivity from back-calculation technique versus average in situ water content 
provide reasonable estimates of in-situ hydraulic conductivity, provided the time interval over which changes in moisture content are measured is close to the time interval of the rain event, during which significant changes in moisture content occur. Further research is needed to establish the reliability of this method compared to other methods, such as in-situ measurements. Potential sources of variability associated with the back-calculation technique include variability in measurements made to obtain the soil-moisture characteristic curve, accuracy of measurement of in-situ water content, and the assumption of a linear average gradient. Also, predicting hysteresis behavior of spent shale using a 2-bar pressure plate apparatus was difficult because of changes in the chemical and physical characteristics of the spent shale due to hydration.

\subsection{Sampling and Testing Following Climatic Simulation}

\subsubsection{RBOSC Field Lysimeters}

A coring program was designed to extract cores from cell 1 of the RBOSC lysimeters. The purpose of this program was to extract "undisturbed" cores from various depths within the lysimeters and conduct identical bench-scale tests to analyze for geotechnical properties and leachate chemistry as were previously described in Section 3 of this report. An alternate objective of the coring program was to analyze cores for gravimetric water content to cross check the water content data obtained by TDR and neutron moderation. A Giddings ${ }^{2}$ soil sampling probe was used with a $5 \mathrm{~cm}$ diameter sampling tube equipped with a $3.6 \mathrm{~cm}$ diameter bit to obtain cores. The $3.6 \mathrm{~cm}$ diameter core size matches the specimen size used for shear strength and leachate chemistry in the bench-scale testing program. Drilling methods included both rotary drilling with a thin-walled sampler designed for sensitive soils and hammering a core into the processed shale.

Efforts to obtain intact cores from the RBOSC lysimeters were undertaken during two visits to the site during July and August 1989. These efforts were not successful. Only highly disturbed

\footnotetext{
${ }^{2}$ Giddings Machine Co., Inc. Fort Collins, Colorado.
} 
materials were recovered by both drilling methods. It is our opinion that the processed shale in the field lysimeters is not cemented sufficiently to obtain intact core samples for strength testing. Studies on potential changes in the physical and constitutive properties of weathered processed shale would have to be conducted on samples that are weathered artificially in the laboratory. These studies have been described along with the bench-scale testing program in Section 3 of this report.

\subsubsection{Sampling in the ESL Lysimeters}

Samples of spent shale were obtained from the ESL test embankments before application of the final freeze-thaw cycle and during excavation, which occurred during July and August, 1993. Samples obtained before application of the final freeze-thaw cycle were analyzed for particle-size distribution. Results are presented and discussed in Section 4.6.4, and are used to explain differences between hydraulic conductivity of bench-scale specimens and in situ measurements. Samples taken during excavation were tested for unconfined compressive strength and hydraulic conductivity, and are discussed below.

Core samples for unconfined compressive strength and hydraulic conductivity tests were obtained with a rotary drill and a rock/concrete bit. The drill was mounted on a $2^{\prime} \times 2$ ' $\times 1 / 2^{\prime \prime}$ steel plate. This provided sufficient weight to keep the drill from spinning, and it generally served to keep the drill relatively steady. The bit has a $50 \mathrm{~mm}$ ( $1.97 \mathrm{inch}$ ) inside diameter with a $25 \mathrm{~mm}$ ( 1 inch) thick cylindrical piston set inside the bit. This piston was used to extract the samples. Figure 4.17 shows the core drilling operation.

Drilling rates varied widely, ranging from roughly one second per centimeter up to two minutes per centimeter. The highest drilling rates were through dry material with negligible cementation, while the slowest rates were through highly-cemented spent shale with relatively high moisture contents. Samples with significant cohesion sometimes adhered to the side walls of the drill bit, thus the sample lost its integrity as the sample in the bit would spin relative to the 


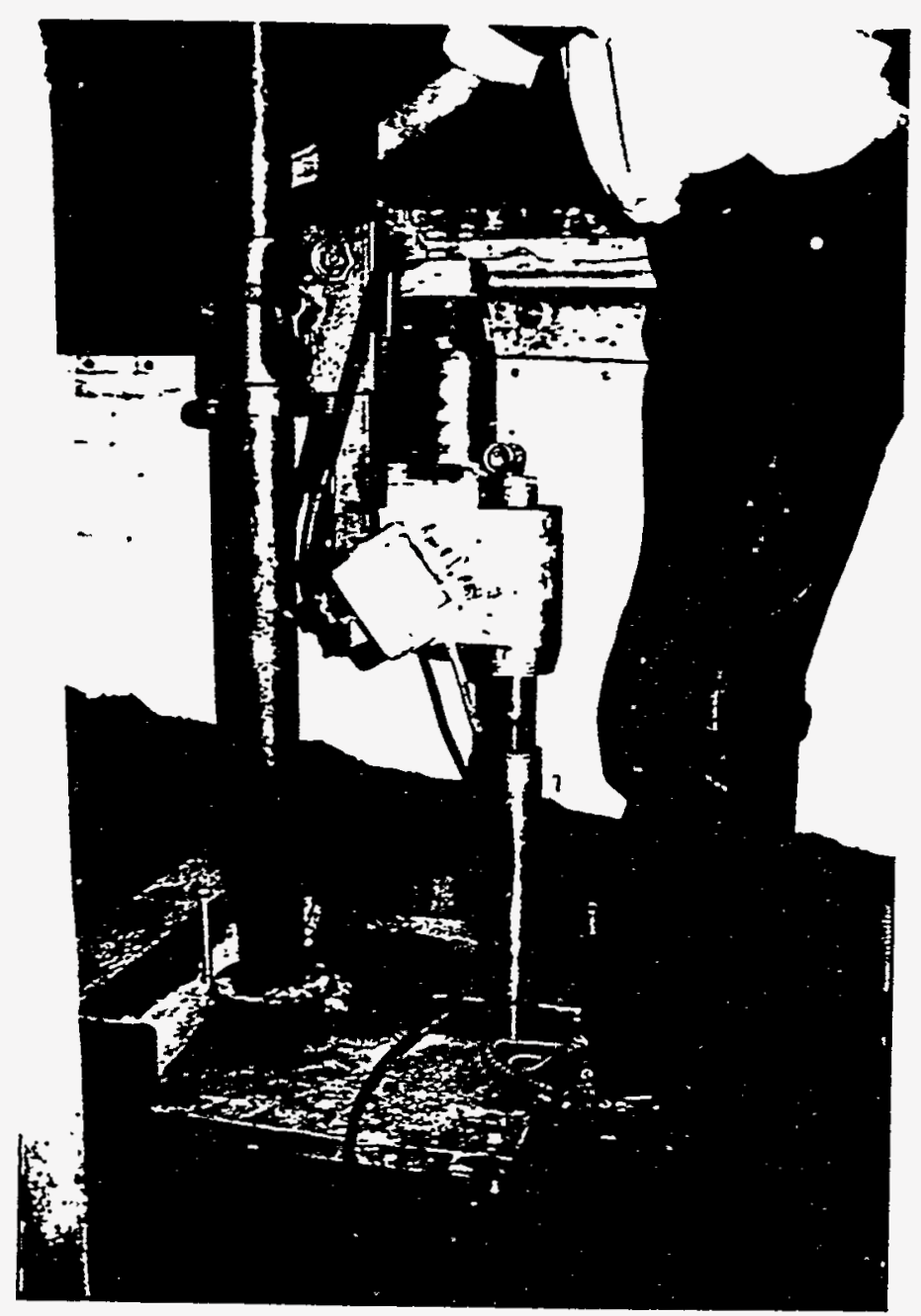

Figure 4.17. Core drilling operation in the ESL 
undisturbed material. This could be detected by the drill operator. The drill encountered little resistance to spinning, but the bit refused to go any lower. Slow drilling generally prevented this, and the operator attempted to drill slowly so sample disturbance was minimized. An attempt was made to obtain duplicate specimens for unconfined compressive strength tests at each depth. However, at some depths it was not possible to obtain an intact specimen. In particular, at depths where the spent shale consisted of aggregated particles with the texture of a lightly-cemented sandy gravel (as described in Section 4.6.3 and shown in Figure 4.12), it was not possible to obtain core samples.

Core samples which were obtained successfully were then extracted from the drill bits. This was accomplished by first freezing the samples in the drill bits. Freezing provided the spent shale with enough strength to prevent the sample from falling apart during extraction from the bit. After several hours of freezing, the samples were removed and placed at room temperature just long enough to thaw the outer layer of the spent shale within the drill bit - about twenty minutes. The drill bit was then placed in an extractor consisting of a one-ton hydraulic jack mounted in a steel box with a hole in the top. A ring was mounted in the hole in the top that was the same diameter as the sample. The jack pushed up on the piston in the bit, and the piston forced the sample out of the bit. Some of the samples failed on extraction, generally by peeling as the samples were forced out of the bit. Some samples simply had too little cohesion to hold together.

Results of unconfined compression tests are given in Table 4.9. As can be observed, there is a high degree of variability, with unconfined compressive strengths ranging from $11.5 \mathrm{kN} / \mathrm{m}^{2}$ (241 psf) to $95.0 \mathrm{kN} / \mathrm{m}^{2}(1,986 \mathrm{psf})$, and overall the values of unconfined compressive strength are significantly lower than the values measured for specimens prepared at bench-scale, as presented in Figure 3.7. This lower strength could be due to sample disturbance, which would tend to destroy the cementitious bonding of the spent shale. The degree of disturbance is difficult to assess but there was undoubtedly some loss of strength. Low strengths could also be due to differences in mixing and compaction procedures for bench-scale specimens compared to the procedures used 
for the test embankments. These differences, which result in different textures because of cementation, also are cited as the reason for differences in in situ and bench-scale hydraulic conductivities, as discussed in Section 4.6. The practical implications are quite significant, suggesting that unconfined compression tests on specimens prepared at bench-scale do not yield representative values of the actual in situ strength of spent shale. Design values of strength for stability analyses should be based on actual in situ strengths which are considerably lower than strengths of bench-scale specimens.

Hydraulic conductivity tests were performed on core samples from several depths. The testing apparatus consisted of a triaxial chamber and flow pump, as described in 3.3 .5 of this report. Confining pressures corresponding to the in situ vertical overburden stress were applied for each specimen.

Several problems were encountered in conducting hydraulic conductivity tests on core samples. These included difficulties in obtaining intact cores and problems with leakage in the permeameter device. The result is that a limited number of core specimens were tested successfully. Results of these tests are summarized in Table 4.10 below. The measured values of saturated hydraulic conductivity are relatively low compared to in situ measurements made with the Guelph permeameter and double-ring infiltrometer, but consistent with values of $\boldsymbol{k}_{\text {sed }}$ measured on specimens prepared at bench-scale. This behavior can be explained by the observation that the cores tested successfully were obtained from zones where the spent shale consisted of a highly cemented matrix with inclusions of aggregated particles, very similar to specimens prepared at bench-scale. Spent shale with this type of texture exhibits hydraulic conductivities in the range of $10^{-7}$ to $10^{-5} \mathrm{~cm} / \mathrm{sec}$. Zones consisting of aggregated particles which are lightly cemented or not cemented at all were not possible to sample or the samples fell apart before they could be tested, and are therefore not represented in the results. 
Table 4.9. Unconfined Compressive Strength of Core Samples.

\begin{tabular}{ccc}
\hline $\begin{array}{c}\text { Sample Depth } \\
(\mathrm{cm})\end{array}$ & $\begin{array}{c}\text { Moisture Content } \\
(\%)\end{array}$ & $\begin{array}{c}\text { Unconfined Compressive } \\
\text { Strength }\left(\mathrm{kN} / \mathrm{m}^{2}\right)\end{array}$ \\
\hline 66 & 25.8 & 58.6 \\
97 & 22.2 & 69.5 \\
98 & 22.2 & 47.8 \\
98 & 22.6 & 95.0 \\
104 & 22.9 & 69.5 \\
157 & 18.4 & 16.2 \\
157 & 19.4 & 22.0 \\
169 & 18.8 & 12.7 \\
170 & 17.2 & 24.4 \\
188 & 27.7 & 49.2 \\
188 & 26.1 & 45.2 \\
188 & 27.3 & 39.2 \\
198 & 18.1 & 11.5 \\
199 & 19.9 & 12.7 \\
218 & 34.2 & 39.6 \\
218 & 31.6 & 37.5 \\
230 & 34.1 & 56.5 \\
\hline
\end{tabular}

Table 4.10. Saturated Hydraulic Conductivity of Core Samples.

\begin{tabular}{cc}
\hline $\begin{array}{c}\text { Sample Depth } \\
(\mathrm{cm})\end{array}$ & $\begin{array}{c}\text { Hydraulic Conductivity } \\
(\mathrm{cm} / \mathrm{sec})\end{array}$ \\
\hline 25 & $3 \times 10^{-8}$ \\
66 & $2 \times 10^{-5}$ \\
66 & $2 \times 10^{-6}$ \\
66 & $9 \times 10^{-7}$ \\
175 & $9 \times 10^{-7}$ \\
\hline
\end{tabular}




\subsection{Summary}

Experimental procedures and instrumentation for evaluating the response of large-scale model spent shale embankments are described. Results presented in this section demonstrate that water content, curing time, and hydration play an important role in determining the vertical and horizontal hydraulic conductivity of spent shale. Double ring infiltrometer tests indicate that in situ vertical hydraulic conductivities are higher by one to two orders of magnitude compared to bench scale test results. The difference is attributed to differences in texture caused by hydration, cementation, and aggregation of spent shale when mixed in large quantities. Tests conducted using the Guelph permeameter indicate that hydraulic conductivity decreases with increasing water content and increasing depth, because of hydration and possibly the effects of overburden pressure, respectively. Though the pressure plate test can simulate the hysteretic behavior of soil, there is difficulty in accurately predicting hysteresis for spent shale because of changes in the physical and chemical properties of spent shale with water content. If the in situ water content of spent shale can be determined accurately by any method, hydraulic conductivity can be estimated reasonably well using the back calculation technique described herein.

Subsurface sampling of the field test embankments at the RBOSC site was not successful. It was not possible to obtain intact specimens for laboratory testing. Drilling, sampling, and testing of the ESL test embankments showed that there are significant differences between the texture and engineering properties of specimens prepared at bench-scale and the texture and engineering properties of spent shale placed in the embankments. In general, measured in situ hydraulic conductivities are several orders of magnitude greater than hydraulic conductivities of bench-scale specimens. This is attributed to a coarser-grain texture consisting of large aggregated particles when the spent shale is mixed and placed in the test embankments, compared to a more dense, highly cemented texture of bench-scale specimens. Core samples tend to have hydraulic conductivities similar to that of bench-scale specimens, probably because 
it is only possible to obtain intact cores in the zones that are highly cemented and which exhibit textures similar to specimens prepared at bench scale.

Unconfined compressive strengths of core samples were considerably lower than that of bench-scale specimens. This may be due to sample disturbance during core drilling, differences in texture between bench-scale and in situ samples, or a combination of both factors. 


\subsection{Numerical Modeling of Spent Shale Waste Embankment Hydrologic Response}

A major goal of the research described herein was to assess the usefulness of computer codes for modeling the hydrologic response of large-scale spent shale waste embankments. This section describes two efforts to achieve that goal. The first is a critical review of computer codes which have capabilities applicable to the hydrogeochemical behavior of spent shale embankments, such as infiltration, seepage, and solute transport. The second effort involved using the program UNSAT2 to model the hydrologic response of the test embankments in the Environmental Simulation Laboratory. Predictions of infiltration and seepage made with UNSAT2 are compared to measured values for the twenty-three rainfall events which were applied as part of the climate simulation for hydrologic analysis.

\subsection{Evaluation of Hydrogeochemical Models for Analysis of Oil Shale Solid Waste Embankments}

When solid waste generated from an oil shale retorting process is disposed of on land, it is necessary to assess the effects of the disposal facility on the surrounding environment for both the regulatory agencies and the oil shale industry in order to be able to answer the question "When and to what extent should leachate be controlled?" Such answers depend on our ability to accurately simulate movement of leachate constituents through the subsurface adjacent to the disposal facility. Another important follow-on question is "What is the best method of controlling the transport of harmful constituents in the oil shale waste leachate?" Computer codes that contain models of processes important to leachate migration can help to answer this question by evaluating alternative disposal facility designs or alternate clean-up strategies.

Accurate simulation depends on understanding hydrological, geochemical, and microbial processes that make leachate constituents mobile. Selected models which address these processes 
and the questions above and which are very important for the transport of solute and flow have been chosen for further evaluation in this section.

To study the transport of dissolved materials in a subsurface flow system, the velocity field, pressure distribution, and moisture content must be determined. Numerous models that use finite difference and finite element approximations have been reported in the literature for simulating flow in saturated and unsaturated porous media (Reeves and Duguid 1975, Segol 1976, Van Genuchten et al. 1977, Narasimhan and Witherspoon 1977, Huyakorn 1986). The variations in these models lie mainly in the number of space dimensions, the utilization of numerical or finite difference methods, the treatment of initial boundary conditions, and the consideration of a source/sink representation within the model.

The discussion which follows first addresses the computer codes which are capable of describing and analyzing transport and flow in some manner. This is followed by a discussion of the requirements for input and details of the models to handle oil shale solid waste in the natural environment.

\subsubsection{Computer Code Selection}

A literature review was initiated as the first step in the development and validation of hydrogeochemical models capable of predicting the migration and fate of leachate released from solid waste disposal of oil shale. One part of the literature review is to evaluate and select certain codes which can predict the migration of the leachate and/or the composition of the leachate. The evaluation of codes was based upon: (1) the development of selection criteria, (2) availability of the codes, and (3) identification of fundamental physical and geochemical processes which the model code will describe.

A two-level selection process was adopted to screen the list of available codes and reduce the number of models to be evaluated to a manageable size, and to select a set of codes 
representative of tests that could be used to predict leachate composition and migration. The codes were classified according to the process or processes they model (i.e hydrological and geochemical processes). Initial evaluation issues included the following:

Does the code/model:

a. Rely on well defined parameters?

b. Provide the necessary boundary and initial conditions?

c. Represent the problem domain?

d. Provide output readily usable with plotting routines?

e. Represent the best available technology?

Is the code/model:

a. User friendly?

b. Well documented?

c. Readily transferable?

d. Robust (rejects erroneous input data)?

e. Well behaved in terms of convergence, mass conservation, and sensitivity?

f. Complete in terms of process model and data base?

\subsubsection{One-Dimensional Hydrological Codes}

Four codes were selected: SESOIL, OR-NATURE, UNSATID, and IDFEMWATER. These codes were evaluated for their ability to simulate moisture fronts in a dry soil profile. Basically, each code requires a description of the geometry and physical characteristics of the soil profile.

The moisture model in SESOIL uses a single average or equivalent soil to represent the soil layers. OR-NATURE is designed to emulate a single soil with soil characteristic data. UNSATID models plants and soil with multiple soil layers. It accepts plant parameters and soil characteristic data for each soil layer. Each code provides a moisture distribution with depth. Output from 
OR-NATURE and UNSATID contain vitually the same detail; however, the UNSATID results include the influences of the plants and multiple layers. In addition to the soil moisture, these two codes calculate the vertical distribution of potential or pressure. Differences in computing results of the three codes arise in their conceptual model of the soil column. SESOIL is designed to provide long term simulations with a minimum of soil column detail. OR-NATURE and UNSATID have been developed from an interest in the short-term events that govern the detailed response of moisture in the soil profile.

IDFEMWATER is very flexible and capable of modeling a wide range of real-world problems. The model is designed to (1) treat heterogenous media consisting of many geologic formations, (2) consider distributed and point source/sinks that are spatially and temporally variable, (3) accept prescribed initial conditions or obtain them from steady state simulations, (4) deal with transient heads distributed over the Dirichlet boundary, (5) handle time-dependent fluxes caused by pressure gradients on the Neumann boundary, (6) treat time-dependent total fluxes, (7) automatically determine variable boundary conditions of evaporation, infiltration, or seepage on the soil air interface, (8) provide two options for treating the mass matrix, (9) provide three alternatives for approximating the time derivative term, (10) give three options (exact relaxation, under-relaxation, and over relaxation) for simulating the non-linear matrix design of the equations, and (11) automatically reset the time step size when boundary conditions or source/sinks change abruptly. 1DFEMWATER consists of a MAIN program, a section of BLOCK DATA, and 18 subroutines. MAIN is used to specify the sizes of all arrays. The control and coordinating activities are performed by the subroutine GWID. Figure 5.1 shows the structure of the program.

\subsubsection{Two-Dimensional Hydrological Codes}

Three hydrologic codes which model water movement and solute transport in a two-dimensional variably saturated medium are described. These codes are TRUST/MILTRAN, 


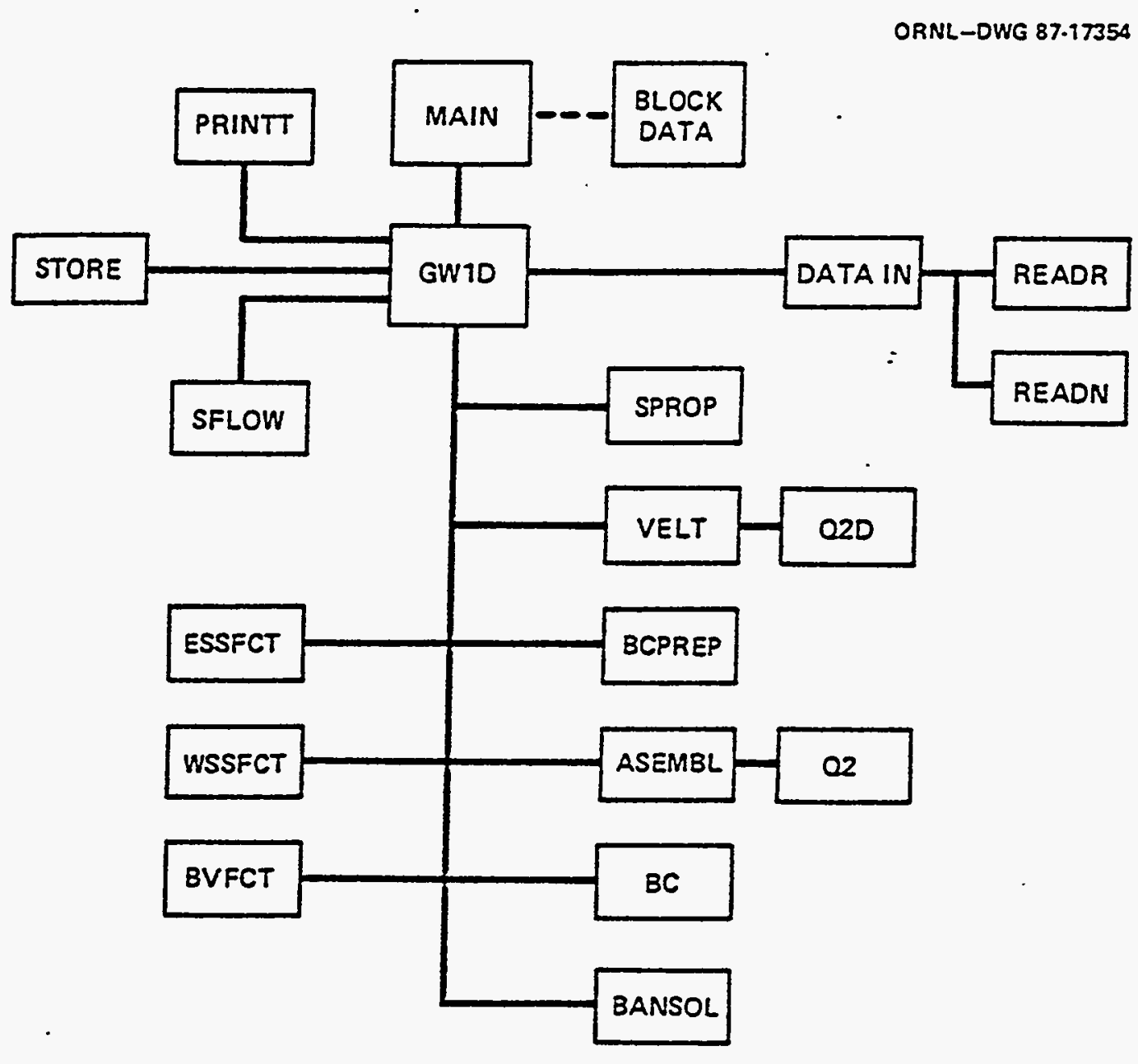

Figure 5.1. Program structure of 1DFEMWATER 
FEMWASTE2/FEMWATER2, and SATURN. These three codes have been applied to a pond disposal test case that is characterized by solute migration originating at the upper surface of a fly ash impoundment which leads to a river. Both moisture movement and solute migration are modeled. Input data for each code includes the geometry of the domain (i.e. two- dimensional vertical cross section) and the physical properties of each medium.

Each code produces a pressure distribution and a field of velocity vectors. The principle difference in these codes lies in their transport model design. A kinematic pathline model (MLTRAN) is coupled with TRUST, while the FEMWASTE2 and SATURN transport codes are both based on advection/diffusion equations. The principle differences in data requirements for the codes are derived from the diffusion-type dispersion model and the grid discretization concentration contours and profiles which are products of the advection-diffusion models. Mass flux at points and boundaries are products of the kinematic pathline model. Results of the advection-diffusion models can be integrated at boundaries to provide mass flux information. However, mass flux results can be converted to concentration only if the volume of the water associated with the solute is known or assumed. Another 2-dimensional code is UNSAT2. UNSAT2 was developed to simulate nonsteady flow of water in saturated-unsaturated media. UNSAT2 uses a finite element method, a fully implicit iterative algorithm, and a Gaussian elimination method.

\subsubsection{Geochemical Codes}

After examining the different available geochemical codes, and evaluating their modeling potential and performance, EQ3/EQ6, MINTEQ, and GEOCHEM were chosen for further evaluation. Table 5.1 indicates the criteria for selection or rejection of the different geochemical codes. A number of considerations entered into the choice of these three codes. Other codes such as EQUILIB and REDEQL.UMD have not been excluded from consideration but are less desirable. For example, the adsorption algorithms in REDEQL.UMD and the data base of organic ligand in 
Table 5.1. Criteria for Selection or Rejection of Geochemical Codes.

\begin{tabular}{lll}
\hline Code & Select - Reject & Reasons \\
\hline GEOCHEM & Select & $\begin{array}{l}\text { Available in the public } \\
\text { domain. Documentation } \\
\text { marginal. Recently } \\
\text { updated. Database } \\
\text { probably the largest } \\
\text { available. }\end{array}$ \\
MINTEQ & Select & $\begin{array}{l}\text { Available in public } \\
\text { domain. Well documented. } \\
\text { Includes adsorption. } \\
\text { Modular construction. } \\
\text { Database is the well } \\
\text { documented. One of } \\
\text { largest available. }\end{array}$
\end{tabular}

EQUILIB Reject

EPRI proprietary code.

Well documented. Models precipitation but not adsorption. Database quite extensive and reasonablywell documented. Can use other databases. Method of solution involves unique elements.

EQ3/EQ6 Reject

Publicly available. Documentation available for EQ3 only. Contains precipitation but no adsorption.

CHEMIST Reject

Publicly available. Old andinadequate documentation. No precipitation/adsorption and no unique modeling. 
GEOCHEM could well be recommended as part of a comprehensive geochemical modeling capability.

MINTEQ was chosen for further examination on the basis that its convergence algorithm is mathematically compact, its data base is extensive, and it has the widest available adsorption capability. Because of its mathematical simplicity, it also appears to have the desired elements that could be incorporated into a geochemical coupling module to a hydrological model.

\subsubsection{Comparison of One-Dimensional Unsaturated Flow Codes}

Code Limitations. The obiective of the code evaluations based on a one-dimensional landfill test case was to identify the codes that are the most capable of simulating water movement in a landfill settinq. Of the three codes discussed above (SESOIL, OR- NATURE. and UNSAT1), only UNSAT1 is capable of handling the multilayered sand and fly ash soil system. OR-NATURE is applied to the fly ash column only, and SESOIL characterizes and solves a three layer system as an equivalent homogeneous soil column. The inability of the OR-NATURE and SESOIL codes to model a soil column made up of more than one material is a severe constraint. Landfills are typically comprised of up to four or more materials: the surrounding soil, a liner, the fill, and the soil cover. Liners and covers may consist of several sublayers, each having different hydraulic properties.

Solute transport modeling was not included in the landfill test case for one-dimensional unsaturated zone codes. Despite this omission, the importance of predicting the migration and fate of solute in the soil column is recognized. UNSAT1 is the only code that does not contain a solute transport component or affiliated transport capability.

The largest drawback to UNSAT1 is its lack of a solute transport capability, this is a serious deficiency that can not be overlooked. While it is true that an independent transport code could be used to model the movement of solute based on the UNSAT1 predicted pressure distribution, neither efficiency nor numerical consistency is well served by such an arrangement. 
Computational Time. Table 5.2 is a comparison of the computation time required by each of the codes on a DEC VAX 11/780. As a consequence of the different formulations and limitations of these codes, the relative computational efficiency of these codes can not be generalized. The only conclusion that can safely be drawn is that for similar landfill analysis, these codes could be expected to require the indicated processing time from the evaluation.

The computational time quantified in Table 5.2 confirms the similarity in design of the UNSAT1 and the OR-NATURE codes. These two codes use a strictly numerical modeling approach and are designed to address a complex water movement problem with relatively fine resolution.

Table 5.2. Comparison of Computation Times Required by One-Dimensional Codes on the DEC VAX 11/780

Code

Computation Time
CPU Seconds (VAX 11/780)

SESOIL

OR-NATURE

UNSAT1

\subsubsection{Comparison of Two-Dimensional Codes}

FEMWATER2/FEMMASTE2. FEMWATER2 and FEMWASTE2 are complementary codes designed to be used in tandem. Although FEMWASTE2 can be applied using the flow field from any flow model, the code is most efficiently applied in conjunction with results from FEMWATER2. Indeed, few additional data are necessary to perform a transport simulation once FEMWATER2 has solved the flow problem. The FEMWATER2/FEMWASTE2 tandem has the most flexibility of the un saturated zone codes evaluated. The use of triangular and quadrilateral finite elements allows for even the most irregular geometry configurations to be accurately portrayed. The FEMWATER2 code 
has the most complete array of boundary conditions of any code. Dirichlet, Neuman, and mixed boundary conditions, both constant and time varying, are included in FEMWATER2. A computed head/flux boundary condition allows for rainfall and ponded runoff to enter the modeled system or evaporation and seepage to leave, depending on the dominant process. Data entry in the flow code is well designed with the more tedious requirements reduced considerably by automatic data generation algorithms.

Numerically, the FEMWASTE2 transport code is almost identical to the FEMWATER2 formulation. Boundary and initial conditions are analogous with pressure as the dependent variable in the flow code and solute concentration as the dependent variable in the transport code. More importantly, the same finite element scheme is used in both codes resulting in a numerically consistent solution. Processes modeled by the transport code include advection, dispersion, adsorption, and degradation. Although most groundwater transport codes solve a linear partial differential equation, FEMWASTE2 can also model non-linear adsorption using a Freundlich or Langmuir isotherm. The non-linear formulation is treated with a variable relaxation iteration method. FEMWATER2 and FEMWASTE2 include a large assortment of numerical procedures designed to speed convergence and give the user optional approaches to a solution.

As reflected in the above discussion, the FEMWATER2/FEMWASTE2 codes have few limitations and represent state-of-the-art technology. These codes are designed for two-dimensional analysis, and consequently, computation time is large in comparison to one-dimensional code analysis.

SATURN Code. The SATURN code contains both flow and transport submodels in a single formulation, however, the submodels are not directly coupled. SATURN is executed separately either as a flow model or as a transport model. If the flow field is established with SATURN or any other flow code, a transport simulation can be performed. The most efficient and accurate method of simulation of solute migration with SATURN is to use SATURN flow results as input to the transport 
simulation because the two submodels share the same finite element solution scheme and they provide a numerically consistent result.

The range of application of the SATURN code is more limited in some respects than the FEMWATER1/FEMWASTE1 codes because it can not handle seepage boundary conditions or non-linear adsorption. However, SATURN does have one of the most efficient finite element algorithms currently available. For similar problems, SATURN can be expected to expend an order of magnitude less computational time than traditional finite element schemes based on Gaussian quadrature. This efficiency is a result of the influence coefficient technique of Huyakorn et al., which dispenses by storing integration coefficients that are accessed during solution.

Computational Time. A comparison of the computational time required by each of the codes on the DEC VAX 11/780 is presented in Table 5.3. This information is based on time required for a single simulation and does not include any measure of man hours required to prepare the input or interpret results.

Table 5.3. Comparison of Computation Times Required by Two-Dimensional Codes on the DEC VAX $11 / 780$.

\begin{tabular}{ll}
\hline Code & $\begin{array}{l}\text { Computational Time } \\
\text { CPU Seconds (VAX 11/780) }\end{array}$ \\
\hline FEMWATER2 & 6,558 \\
FEMWASTE2 & 11,502 \\
Saturn - flow & 927 \\
- transport & 2,279 \\
TRUST & 12,067 \\
MLTRAN (11 pathlines) & 80 \\
\hline
\end{tabular}




\subsubsection{Summary of Computer Code Capabilities}

The information that follows describes pertinent material related to several of the computer codes which were evaluated.

\section{A. UNSAT1 - CODE}

This model is designed to simulate infiltration, vertical seepage and uptake by plant roots. Information required: Soil properties, soil profile, root growth characteristics, evaporation rates, and precipitation.

Numerical technique(s): UNSAT1 uses a finite difference method and Gaussian elimination solution technique.

Description: UNSAT1 is a one-dimensional, finite difference, fully implicit code for simulating groundwater flow in the unsaturated zone. Hydraulic conductivity between nodes can be calculated as either an arithmetic mean or a geometric mean. As the code is one-dimensional, it is designed to treat unsaturated zone water flow for an already uniform situation. Areal uniformity applies to driving forces such as precipitation, irrigation and ponding and to the medium properties such as hydraulic conductivity and porosity.

Programming: The UNSAT1 model is coded in FORTRAN IV and is operational on the DEC PDP $11 / 70$ and VAX $11 / 780$ computer systems.

\section{B. TRUST - CODE}

TRUST numerically simulates soil water content and pressure distributions in multidimensional systems in subsurface flow and transport via a kinematic pathline subroutine (MLTRAN). Numerical technique(s): TRUST uses an integrated finite difference method and an explicit-implicit point iterative solution technique.

De-scription: TRUST is actually a computer program for the transient and steady-state temperature 
distribution in a multidimensional system that has been used in subsurface flow and involves integrated finite difference methods (IFDM).

Programming: The TRUST model is programmed in FORTRAN and is operational on both a CDC and DEC VAX $11 / 780$.

\section{1DFEMMATER and FEMWATER2- CODE}

1DFEMWATER and FEMWATER2 are finite element models of water flow through saturated-unsaturated porous media. The FEMWATER codes simulate groundwater flow dynamics in saturated unsaturated subsurface systems.

Information required: Porosity, water holding capacity, hydraulic conductivity, compressibility coefficient of the media and modified water compressibility coefficient.

Numerical technique(s): FEMWATER uses a finite element method and a Gaussian elimination solution technique.

Description: FEMWATER is a revised finite element model of water flow through porous media. The response of the groundwater basin to rainfall, artificial withdrawal and other recharge or discharge sources (lakes, reservoirs, and streams) may be included. The model has been modified and expanded from a previous model developed at Oak Ridge National Laboratory. Modifications include: (1) computing the flowfield in a way consistent with the finite element approach, (2) evolution of the moisture content as an increasing rate within the region by a new method consistent with solving for moisture content and pressure fields, and (3) treating the nonlinear terms to ensure that a unique relationship between any nonlinear variable and pressure is preserved. The expansion provides four alternative numerical schemes that are more appropriate for many situations. The model can simulate flow in porous media in transient or steady-state, one or two dimensions and saturated and/or unsaturated media. The model is based on the laws of conservation of mass and momentum and includes soil and water compressibility effects. Water is exchanged between surface and 
subsurface media through seepage or ponding, infiltration runoff from rainfall, artificial recharge and withdrawal and ponds, lakes and streams.

Programming: FEMWATER is written in FORTRAN and is operational on both IBM 360 and CDC equipment.

\section{FEMWASTE2 - CODE}

FEMWASTE computes transport through porous media under dynamic groundwater conditions. Information required: FEMWASTE requires standard soil and aquifer properties such as adsorption distribution coefficients, bulk density, longitudinal dispersivity, transverse dispersivity, decay constant, porosity and modified coefficient of compressibility.

Numerical technique(s): FEMWASTE uses a finite element method and a Gaussian elimination solution technique.

Description: This finite element model of waste transport through porous media simulates the spatial and temporal distribution of both waste concentration and flux under dynamic groundwater conditions. The transport mechanisms include advection, hydrodynamic dispersion, chemical sorption

and first-order decay.

Programming: FEMWASTE is written in FORTRAN and is operational on both IBM and CDC systems.

\section{E. SATURN - CODE}

SATURN is a finite element model for simulating saturated unsaturated flow and radioactive radionuclide transport.

Information required: System geometry in horizontal and vertical dimensions, saturated hydraulic conductivity tensor, saturated specific storage, effective porosity, constitutive relationship for relative 
conductivity versus saturation and saturation versus pressure head, prescribed values of pressure head, prescribed values of nodal fluid flux, longitudinal dispersivity, transverse dispersivity, molecular diffusion coefficients, decay coefficient, retardation coefficient, initial inventory of solute, leach duration, prescribed values of concentration, and prescribed values of solute flux. Numerical technique(s): The flow equation is descretized using the Galerkin finite element method. Nonlinearity is treated using either picard or Newton-Raphson iterations. The transport equation is discretized using an upstream-weighted finite element method designed to alleviate the problem of numerical oscillations. Simple rectangular and triangular elements used.

Description: SATURN is a two dimensional finite element model developed to simulate fluid flow and solute transport processes in variably saturated porous media. The model solves the flow and transport equations separately. Transport mechanisms considered include advection, hydrodynamic dispersion, adsorption and first-order decay.

Programming: SATURN is written in FORTRAN with versions existing on PRIME, DEC VAX 11/780 and $C D C 7600$ computers.

\section{F. CAMCON - PACKAGE}

The purpose of CAMCON (Compliance Assessment Methodology Controller Computer Package) is to allow an analyst to properly build and execute portions or all of a compliance assessment of groundwater for any specific scenario. CAMCON resides at Sandia National Laboratories in New Mexico.

The following computer modules, grouped by category, re available in CAMCON:

1. Mesh generation modules

a. GENMESH - a three dimensional finite-difference mesh generation code.

b. GENNET - a network generator code.

2. Monte Carlo sampling modules a. LHS - latin hypercube sampling code

3. Regional and Local hydrologic modules 
a. SUTRA - a finite element simulation code for saturated-unsaturated, fluid density dependent groundwater flow with energy transport or chemically reactive single species solute transport.

b. SWIFT II - a Sandia waste isolation flow and transport code for fractured media which solves transient, three dimensional coupled equations and radionuclide miscible displacement.

c. HST3D - a computer code for simulation of heat and solute transport in a three dimensional groundwater system.

4. Repository/Shaft module

Currently, repository/shaft modules use a combination of SUTRA, SWIFT II, HST3D and NEFTRAN.

5. Transport module a. NEFTRAN - a network flow and transport code.

6. Containment calculation module

a. CCDFPLT - a code to calculate and plot the complementary cumulative distribution function.

7. Statistical module

a. STEPWISE - a code for stepwise regression analysis.

b. PCC/SRC - a code to calculate partial correlation and standardized regression coefficients.

8. Support modules

a. ALGEBRA - a code that algebraically manipulates data.

b. BLOT - a mesh and curve plot code.

c. C2FINTRP - a code to interpolate boundary conditions from a coarse to fine grid.

d. GRIDGEOS - a code to interpolate from observational hydrologic or geologic data to a computational mesh.

e. MATSET - a code to set material properties

f. TRACKER - a code to track neutrally buoyant particles.

SUTRA is a computer program within CAMCON which simulates fluid movement and transport of either energy or dissolved substances in a subsurface environment and is the code of interest for this project. The model employs a two dimensional hybrid finite element and integrated finite difference method to approximate the governing equations that describe the two independent 
processes that are simulated. The two independent processes are (1) fluid density dependent saturated or unsaturated groundwater flow; and either (2a) transport of a solute in the groundwater, in which the solute may be subject to: equilibrium adsorption on the porous matrix, and both first order and zero order production or decay; or (2b) transport of thermal energy in the groundwater and solid matrix of the aquifer. SUTRA provides a primary information in the results, fluid pressure and either solute concentrations or temperatures as they vary with time. The SUTRA model is based on a general physical, mathematical and numerical structure implemented in the computer code in a modular design. This allows for straight forward modifications and additions to the code.

\section{G. GEOCHEM-CODE}

GEOCHEM is a computer program for the calculation of chemical equilibria in soil solutions and other natural water systems. It does aqueous speciation on 45 elements and 42 organic ligands and reduction/oxidation on many of these same elements.

Information required: total molar concentrations of each metal and each ligand, $\mathrm{pH}$ value, and nature of adsorbing surfaces must be specified if adsorption of metals is to be considered.

Description: GEOCHEM has been specifically designed to calculate chemical equilibria in soil solutions and other natural water systems. A number of modeling options are available which include: (1) solid phases being permitted or excluded with a method incorporated to estimate exchange equilibrium constants, (2) the $\mathrm{pH}$ being varied or fixed, and (3) redox reactions being varied or fixed.

\section{H. MINTEO - CODE}

MINTEQ is a computer program for calculating aqueous geochemical equilibria. It does aqueous speciation on 31 elements. 
Information required: supply temperature in analytical units, ionic strength value and whether or not constant or variable, inorganic carbon and how it is expressed, limit specification on charge balance and number of iterations, Ph variable or constant and what calculating.

Description: MINTEQ has been assembled by combining the computational structure of MINTEQL with the data base from WATEQ4. MINTEQL has in turn evolved from REDEQL and WATEQL from a previous series of WATEQ versions. MINTEQ includes ion speciation, calculation of activity coefficients, and solubility adsorption and mass transfer.

\subsection{NUMERICAL SIMULATION OF INFILTRATION AND FLOW}

To understand the runoff/infiltration and seepage behavior of a full-scale compacted spent shale embankment, a computer simulation of the test embankment response to the rainfall events described in Section 4 was performed. The variably saturated flow model program UNSAT2 was utilized to model water flow through the spent shale embankment. The objective of using this program was to determine if it could be used to predict infiltration, runoff, drainage, and movement of water within the test embankment.

UNSAT2 was used with two sets of hydraulic conductivity data. The first set included hydraulic conductivities measured using the Guelph permeameter (horizontal) and the double ring infiltrometer (vertical). The second set utilized horizontal hydraulic conductivities measured with the Guelph permeameter, but vertical hydraulic conductivities as measured in bench-scale tests.

\subsubsection{Overview of the Program UNSAT2}

The UNSAT2 program developed by Neuman (1974) is intended for analysis of flow in unsaturated, partially saturated, or saturated porous media. It is capable of handling flow regions delineated by irregular boundaries and composed of non-uniform soils having arbitrary degrees of local anisotropy. UNSAT2 can simulate flow in the vertical plane, the horizontal plane, or in three 
dimensional radial symmetry about the vertical axis. The program can deal with boundaries controlled by atmospheric conditions such as seepage faces, and evaporation or infiltration surfaces in addition to conventional head and flux boundaries. The program also has an unique restart feature which updates the boundary condition as well as the boundary values with time. The program utilizes the lumped-mass Galerkin finite element scheme with quadrilateral and triangular elements for solution.

The following basic flow equation, which takes into account advection, drainage, storage, and source/sink terms, is used to calculate water movement within the soil.

$$
L(h)-\sum_{i=1}^{3} \sum_{j=1}^{3} \frac{\partial}{\partial x_{1}}\left[K^{\prime}(h) K_{i j}^{s} \frac{\partial h}{\partial x_{j}}\right]+\sum_{i=1}^{3} \frac{\partial}{\partial x_{i}} K^{\prime}(h) K_{i 3}^{s}-\left[C(h)+\beta s_{j}\right] \frac{\partial h}{\partial t}-s=0
$$

where $L=$ quasilinear differential operator in flow region

$x_{1}=$ spatial coordinates

$K^{\top}=$ relative hydraulic conductivity $\left(0<K^{r}<1\right)$

$K_{\|}^{s}=$ hydraulic conductivity tensor at saturation

$\mathrm{h}=$ pressure head

$C=$ specific moisture capacity $=d \theta / d h$

$\theta=$ volumetric moisture content

$\beta=0$ in unsaturated zone $\& 1$ in saturated zone

$S_{8}=$ specific storage

$\mathbf{t}=$ time

$S=$ source/sink term 
To solve the basic flow equation, initial conditions within the flow region must be specified. The pressure head is assumed to be a single-valued function of the water content and hysteresis is not considered. The numerical solution to the basic flow equation subjected to initial and boundary conditions is obtained by dividing the flow region into a network of triangular or quadrilateral elements and applying Galerkin's method to formulate and solve the element equations. The resulting approximate solution of Eq. 5.1 for the dependent variable pressure head $(\mathrm{h})$ is obtained as a function of the spatial variable $(x)$ and time $(t)$.

UNSAT2 is capable of simulating evaporation and infiltration boundaries by specifying either a prescribed head or prescribed flux boundary. The time intervals for solution are computed independently. At any time step during the first iteration, the program treats the nodes as prescribed boundaries with a flux equal to a fraction of the specified potential and slowly increases for convergence. The program also updates the pressure head and moisture content at every node at every time increment. UNSAT2 can treat the development of a seepage face at any stage of computation and treat the saturated nodes as a prescribed head boundary with pressure head equal to zero, indicating discharge from the porous media through saturated nodes. At the same instant, the unsaturated nodes are treated as prescribed flux boundaries with no discharge.

\subsubsection{Computer Simulation}

UNSAT2 was used to simulate the infiltration and movement of water through the spent shale embankments in the ESL. Spent shale was placed in eight, $0.30 \mathrm{~m}(1 \mathrm{ft})$ thick lifts with a gravel drain at the bottom. The finite element mesh consisted of 462 nodes and 432 elements, providing a twodimensional model of the test embankment, as shown in Figure 5.2. The surface of spent shale in the test embankment slopes gently ( 1 in 48 ) to allow collection of runoff during rainstorms and this was simulated in the model. The entire length and depth of the test embankment was used in the simulation. The model was $7.33 \mathrm{~m}$ (24 feet) long, $2.40 \mathrm{~m}$ ( 8 feet) deep, and $1 \mathrm{~cm}$ thick. 


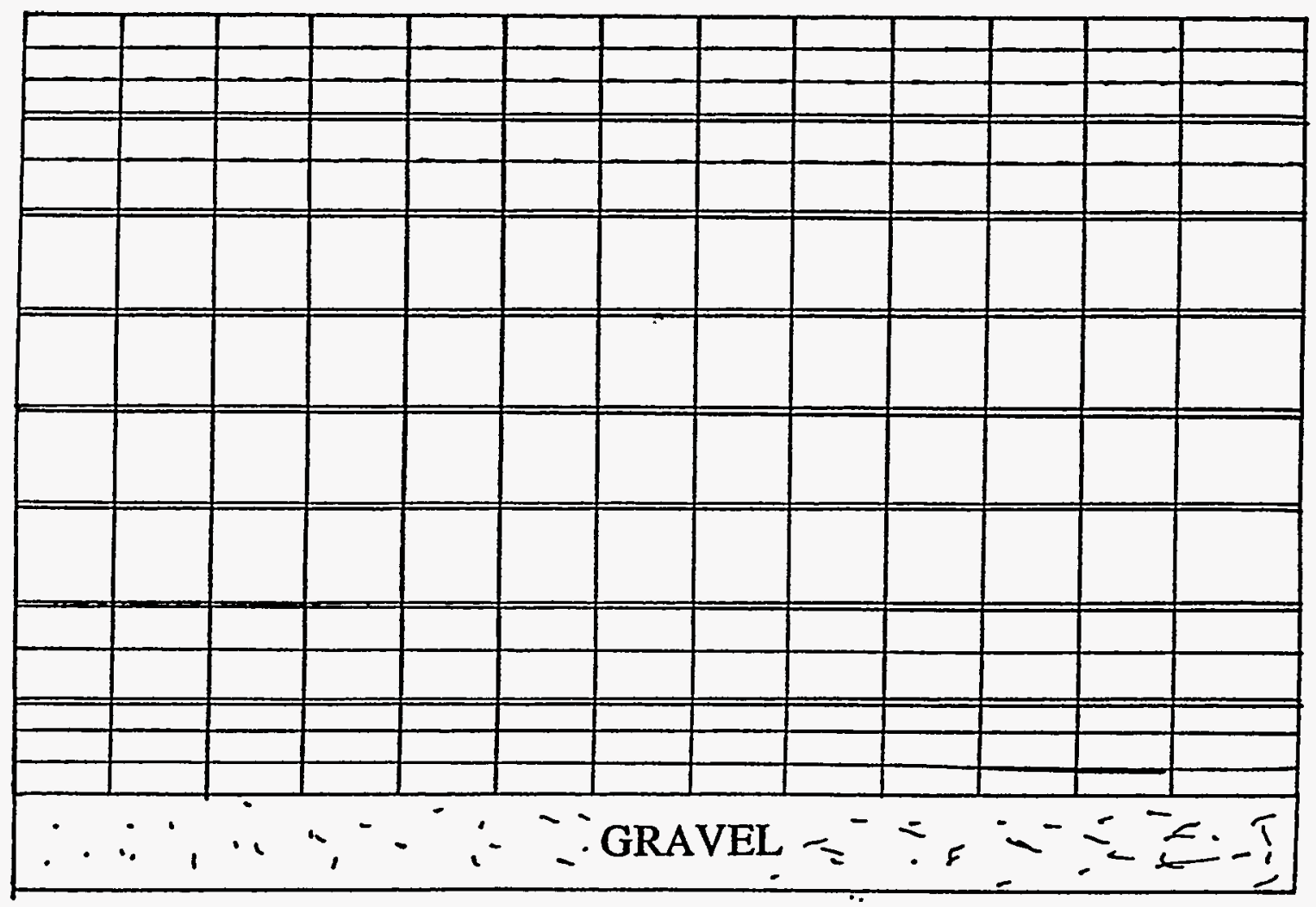

Figure 5.2 Two-dimensional finite element mesh of the test embankment 
The physical property values used as input consisted of porosity, specific gravity, dry density, specific storage, and saturated horizontal and vertical hydraulic conductivities. Specific storage, defined as the volume of water released from storage per unit volume of saturated soil due to a unit decrease in pressure head, is dependent on the moisture content and compressibility effect. Since the compressibility effect of spent shale is very small, a very small value of one percent was assumed. Table 5.4 summarizes the physical properties input into the model from in situ hydraulic conductivity measurements and from bench-scale measurements.

Table 5.4. Physical Properties of Spent Shale.

\begin{tabular}{|c|c|c|c|c|c|}
\hline \multicolumn{5}{|c|}{ Physical Property } & Value \\
\hline \multicolumn{5}{|c|}{ Porosity (n) } & 0.45 \\
\hline \multicolumn{5}{|c|}{ Specific Gravity $(\mathrm{G})$} & 2.67 \\
\hline \multicolumn{5}{|c|}{ Specific Storage } & 0.01 \\
\hline \multirow{2}{*}{$\begin{array}{c}\text { van Genuchten } \\
\text { Model } \\
\text { Parameters }\end{array}$} & \multicolumn{4}{|c|}{$\propto$} & 0.00112 \\
\hline & \multicolumn{4}{|c|}{ n } & 3.70 \\
\hline \multirow{7}{*}{$\begin{array}{c}k \\
(\mathrm{~cm} / \mathrm{hr})\end{array}$} & Material & Lift & $k_{h}$ (in situ) & $\begin{array}{l}k_{y} \text { (in } \\
\text { situ) }\end{array}$ & $k_{v}(\mathrm{Lab})$ \\
\hline & $\# 1$ & Top 6 in & 1.5475 & 5.340 & 0.105 \\
\hline & \#2 & 2nd \& 3rd & 2.3980 & 0.830 & 0.450 \\
\hline & $\# 3$ & 4th \& 7th & 4.4450 & 1.040 & 0.450 \\
\hline & $\# 4$ & 5th \& 6th & 7.2126 & 7.405 & 0.450 \\
\hline & $\# 5$ & 1st \& 8th & 12.2040 & 5.340 & 0.450 \\
\hline & \#6 & Thin Element & 23.8954 & 7.810 & 0.450 \\
\hline
\end{tabular}


Modeling consisted of simulating the top surface as an infiltration face and the bottom as a seepage face. All of the surface nodes were modeled as infiltration nodes and all of the bottom nodes as seepage nodes. The other nodes were modeled as internal nodes but not as a sink or source.

The initial horizontal hydraulic conductivity was approximated from in situ measurements made with the Guelph permeameter and the vertical hydraulic conductivities from measurements made with the double-ring infiltrometer. These data are discussed in Section 4. Since the horizontal hydraulic conductivity showed higher values at the interfaces than between lifts, thin elements with higher horizontal hydraulic conductivity were introduced at the interface between the lifts in the model. This resulted in six material types with different horizontal hydraulic conductivities, as shown in Table 5.4.

The spent shale was modeled for vertical plane flow. An initial moisture content of eight percent was assumed, based on measurements made before applying the rainstorms to the embankment. The soil-moisture characteristic relationship required in the simulation was obtained from pressure plate tests. The relative hydraulic conductivity $\left(K^{\prime}\right)$ at various moisture contents required during the simulation was computed from the van Genuchten expression (van Genuchten, 1980).

The van Genuchten expression is a closed-form equation for predicting hydraulic conductivity of unsaturated soils. The expression is dependent on four independent parameters: residual water content, defined as water content at a very high capillary pressure $\left(\theta_{\mathrm{r}}\right)$, water content at saturation $\left(\theta_{s}\right)$, and curve fitting constants ( $\alpha$ and $n$ ) which have to be estimated from observed soil-water retention data. The curve fitting constants $\propto$ and $n$ are estimated from the absolute value of the slope of the soil-moisture retention curve.

Twenty-three rainstorms were applied to the spent shale embankment in ESL. During each rain event, cumulative runoff was measured every 30 seconds. Infiltration rate was computed as 
the difference between the rate of applied rain and rate of runoff. A typical plot of rate of applied rainfall, measured infiltration, and runoff against time for the first applied rain event is shown in Figure 5.3. Each rain event and the dry period between rain events were simulated and modeled using UNSAT2. Rainfall durations and rates, and dry period durations are summarized in Table 5.5. Infiltration rate was computed at 2.5 minute time intervals. Runoff rate was calculated as the difference between the rate of rain applied to the surface and infiltration. The simulated rates of infiltration and runoff were compared to the measured rates. Figures 5.4 through 5.9 show comparisons of simulated infiltration and runoff, using in situ measured hydraulic conductivities, to measured infiltration and runoff. Figures 5.10 through 5.19 show comparisons of simulated infiltration and runoff, using bench-scale hydraulic conductivities, to measured values. The movement of moisture during the rainstorms and also during the dry periods between rainstorms were modeled using the RESTART feature in the program. These comparisons are discussed below.

It was observed that after the tenth rainstorm the test embankment was completely saturated and started to drain into the gravel layer below. The leachate was collected and measured using collection tanks. Figure 5.20 shows the measured rate of drainage out of the ESL versus time for the 21st and 22nd rainstorm. The model described in this chapter was simulated such that the drainage occurred after the tenth rain event.

\subsubsection{Discussion}

For the first set of data where the hydraulic conductivities were input from in situ measurements, there was no predicted runoff on the surface of the modeled embankment for the first four rainstorms as shown in Figures 5.4 through 5.7. Possible reasons for this behavior could be: (1) the numerical model computes the relative hydraulic conductivity using the van Genuchten expression as a function of water content and soil-moisture characteristics. Since the initial water 


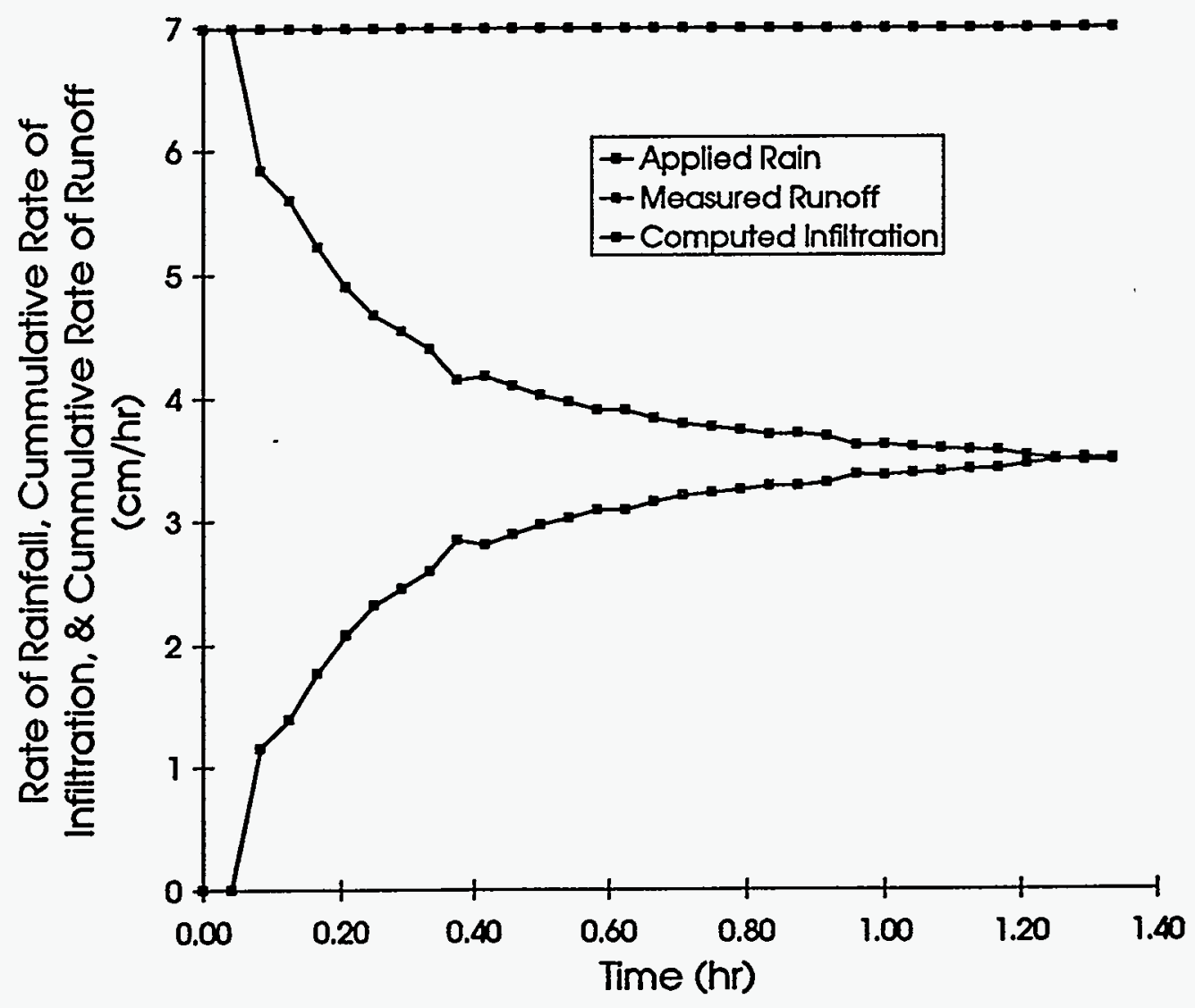

Figure 5.3. Rainfall, infiltration, and runoff for rain event \#1 
Table 5.5. Summary of Rain Event and Dry Period Dates and Durations

\begin{tabular}{|c|c|c|}
\hline Event & Duration (hr) & Rate $(\mathrm{cm} / \mathrm{hr})$ \\
\hline $\begin{array}{l}\text { 1st Rain } \\
\text { 1st Dry }\end{array}$ & $\begin{array}{cc}0-1.336 \\
1.336- & -67.70\end{array}$ & 6.985 \\
\hline 2nd Rain & $67.70-68.59$ & 6.985 \\
\hline $\begin{array}{l}\text { 2nd Dry } \\
\text { 3rd Rain }\end{array}$ & $\begin{array}{c}68.59-164.52 \\
164.52-165.97\end{array}$ & \\
\hline 3rd Dry & $\begin{array}{l}164.52-165.97 \\
165.97-212.95\end{array}$ & 6.985 \\
\hline 4th Rain & $212.95-214.15$ & 7.112 \\
\hline 4th Dry & $214.15-259.70$ & \\
\hline $\begin{array}{l}\text { 5th Rain } \\
\text { 5th Dry }\end{array}$ & $\begin{array}{l}259.70-261.00 \\
261.00-331.78\end{array}$ & 7.239 \\
\hline 6th Rain & $331.78-332.97$ & 7.620 \\
\hline 6th Dry & $332.97-379.96$ & \\
\hline $\begin{array}{l}\text { 7th Rain } \\
\text { 7th Dry }\end{array}$ & $\begin{array}{l}379.96-381.36 \\
381.36-427.82\end{array}$ & 7.112 \\
\hline 8th Rain & $427.82-429.21$ & 7.620 \\
\hline 8th Dry & $429.21-500.77$ & \\
\hline 9th Rain & $500.77-501.99$ & 7.239 \\
\hline 9th Dry & $501.99-547.75$ & \\
\hline 10th Rain & $547.75-549.00$ & 7.239 \\
\hline 10th Dry & $549.00-596.23$ & \\
\hline 11th Rain & $596.23-597.53$ & 7.239 \\
\hline 11th Dry & $597.53-667.38$ & \\
\hline 12th Rain & $667.38-668.71$ & 7.239 \\
\hline 12th Dry & $668.71-716.00$ & \\
\hline 13th Rain & $716.00-717.32$ & 7.239 \\
\hline 13th Dry & $717.32-763.55$ & \\
\hline 14th Rain & $763.55-765.12$ & 7.239 \\
\hline 14th Dry & $765.12-835.42$ & \\
\hline 15th Rain & $835.42-836.78$ & 7.239 \\
\hline 15th Dry & $836.78-883.32$ & \\
\hline 16th Rain & $883.32-884.64$ & 7.239 \\
\hline 16th Dry & $884.64-931.34$ & \\
\hline 17th Rain & $931.34-932.67$ & 7.239 \\
\hline 17th Dry & $932.67-1003.10$ & \\
\hline 18th Rain & $1003.10-1004.53$ & 7.239 \\
\hline 18th Dry & $1004.53-1050.95$ & \\
\hline 19th Rain & $1050.95-1052.37$ & 7.239 \\
\hline 19th Dry & $1052.37-1171.37$ & \\
\hline 20th Rain & $1171.37-1172.96$ & 7.239 \\
\hline 20th Dry & $1172.96-1219.03$ & \\
\hline 21st Rain & $1219.03-1220.24$ & 7.239 \\
\hline 21st Dry & $1220.24-1267.77$ & \\
\hline 22nd Rain & $1267.77-1269.24$ & 7.239 \\
\hline 22nd Dry & $1269.24-1339.11$ & \\
\hline 23rd Rain & $1339.11-1340.61$ & 7.239 \\
\hline
\end{tabular}




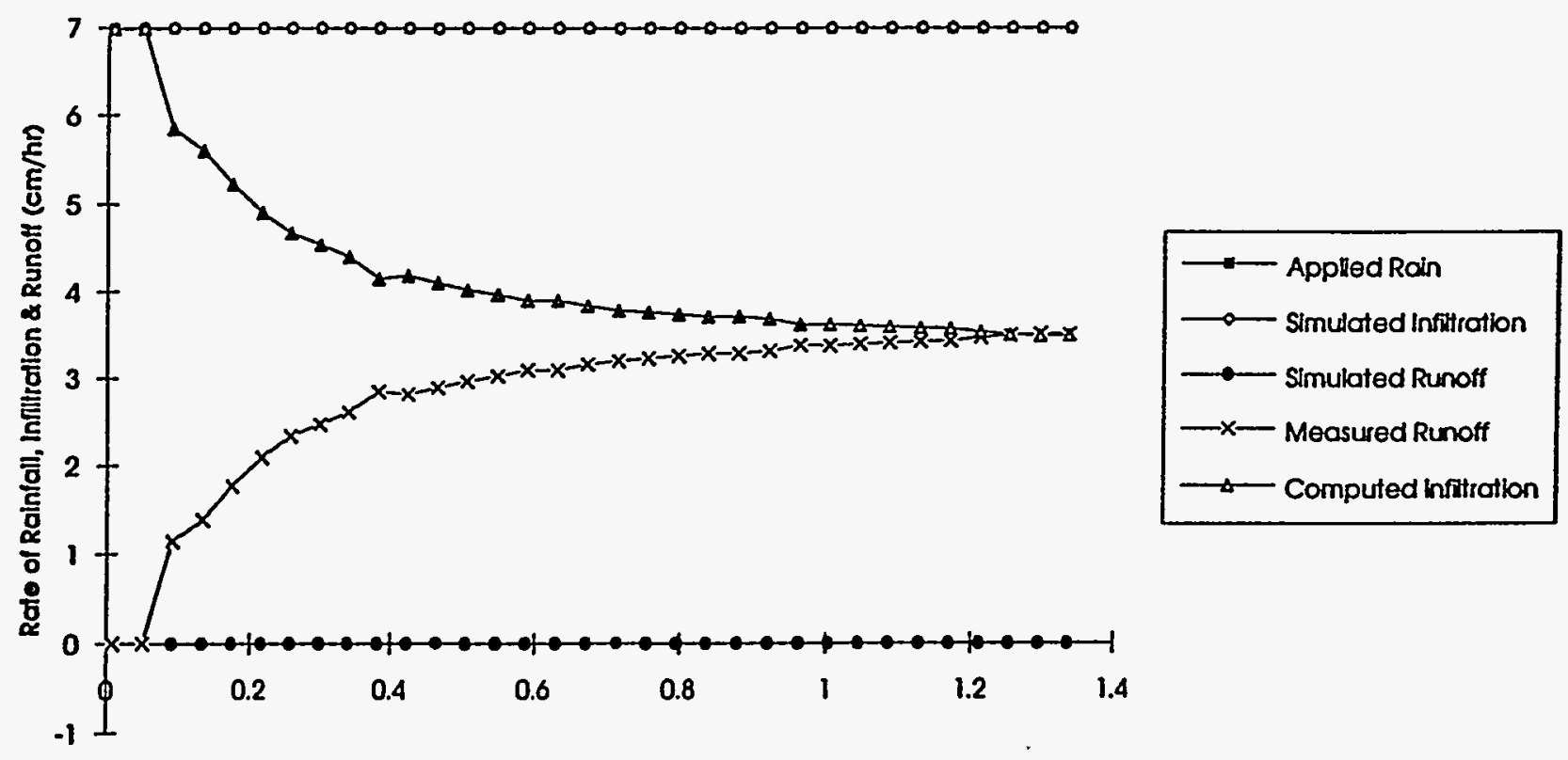

$\operatorname{Time}(\mathrm{hr})$

Figure 5.4. Comparison of simulated infiltration \& runoff to measured response, utilizing in situ hydraulic conductivities, 1 st rain event 


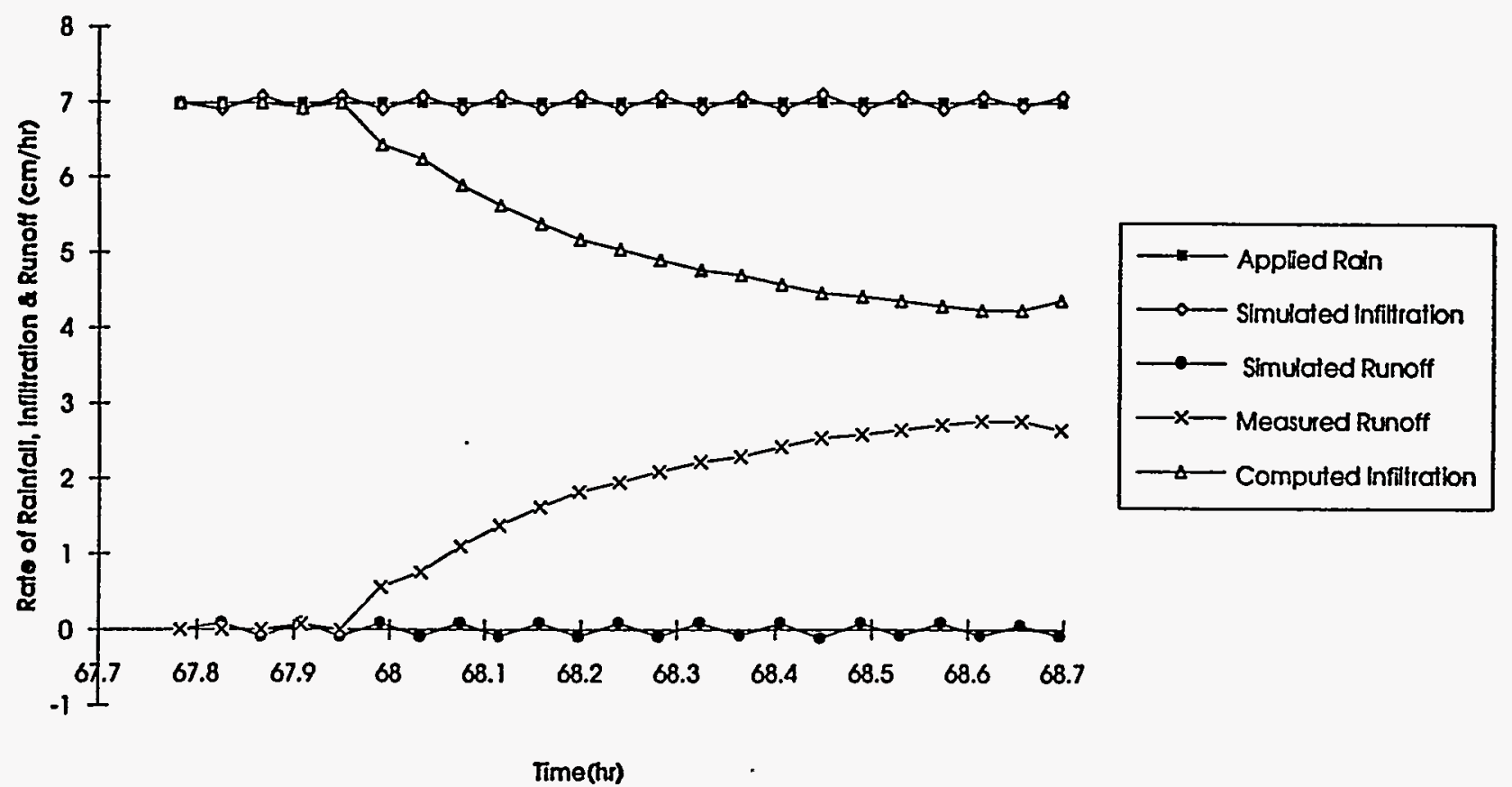

Figure 5.5. Comparison of simulated infiltration \& runoff to measured response, utilizing in situ hydraulic conductivities, 2 nd rain event 


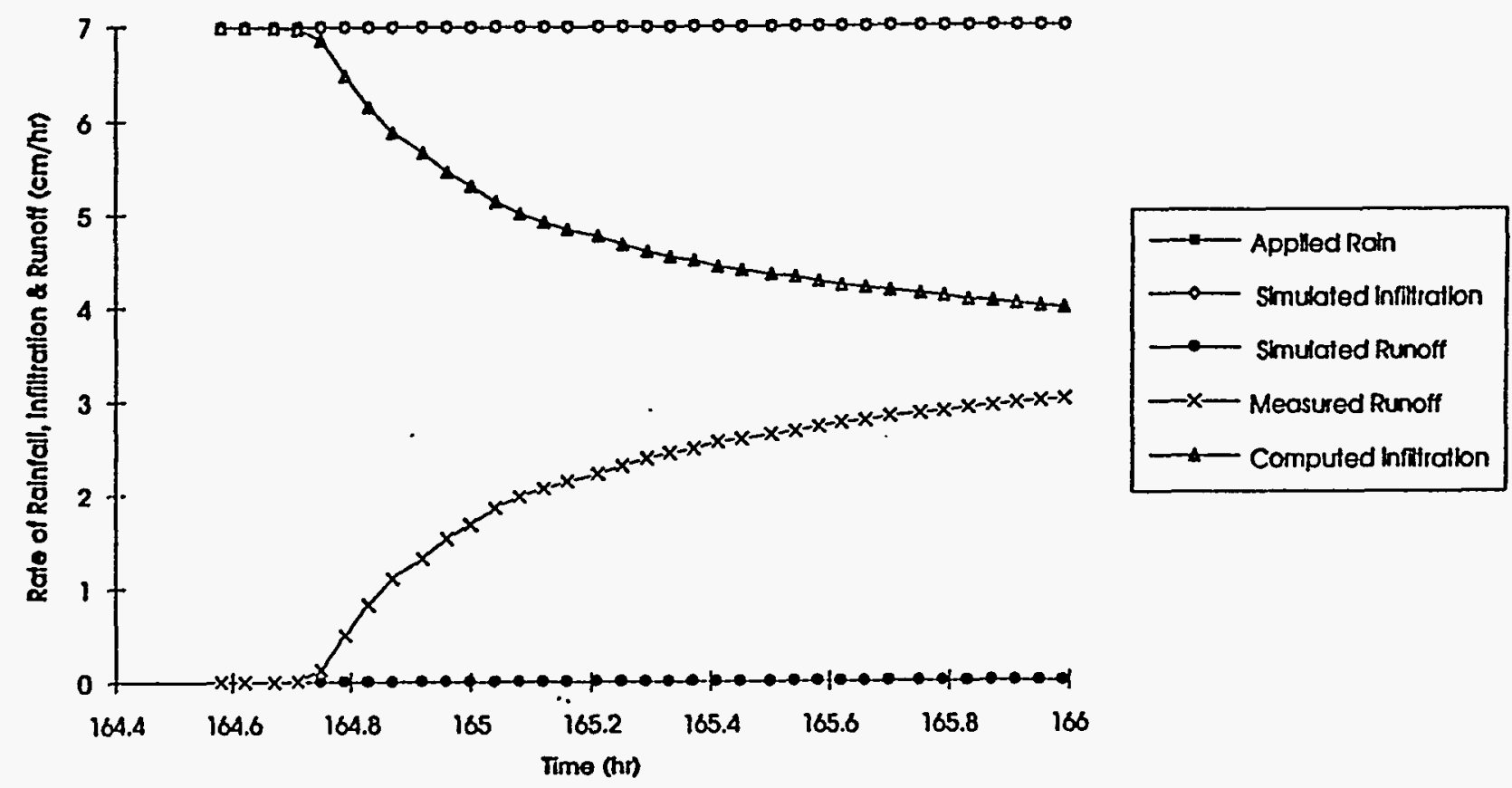

Figure 5.6. Comparison of simulated infiltration \& runoff to measured response, utilizing in situ hydraulic conductivities, 3rd rain event 


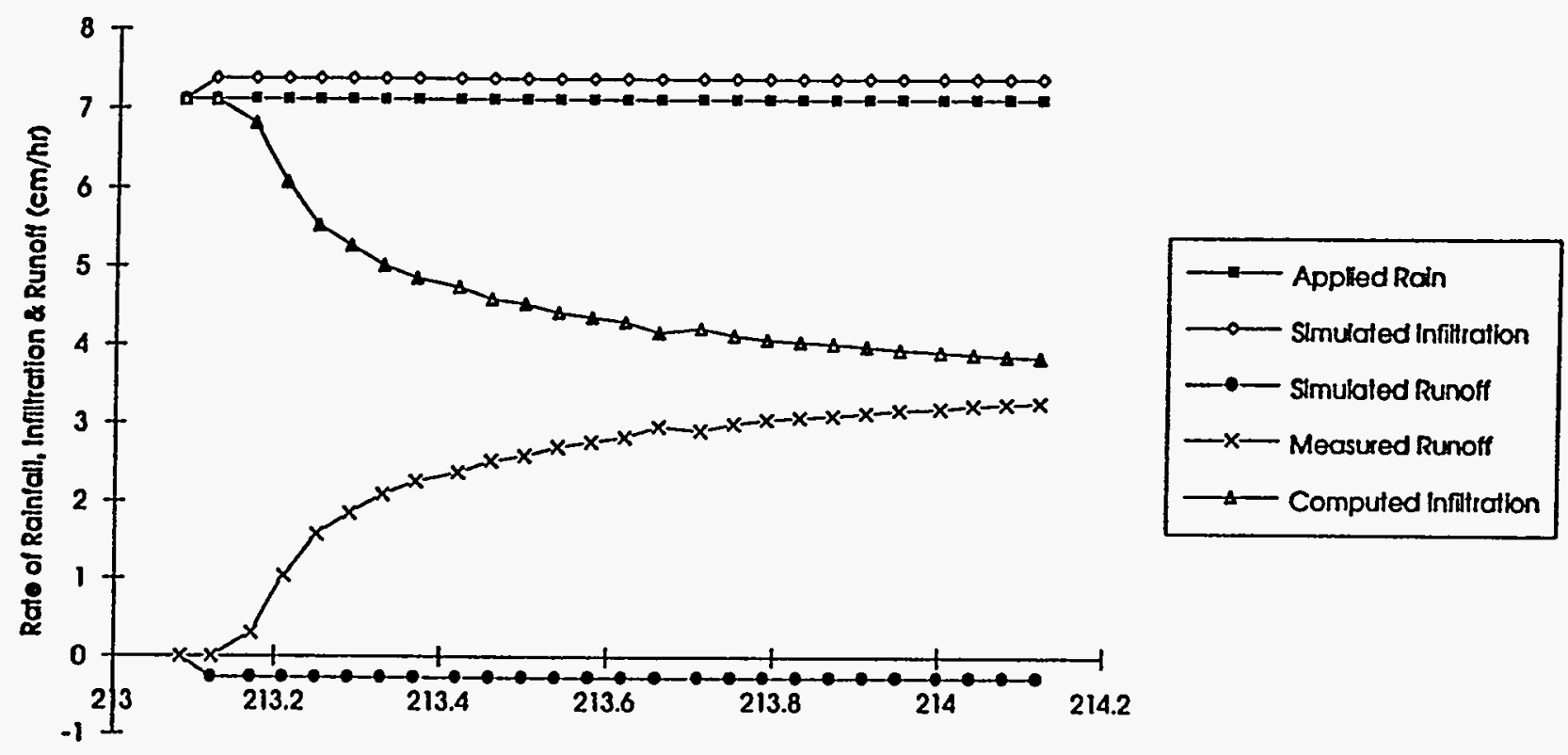

$\operatorname{Time}(\mathrm{hr})$

Figure 5.7. Comparison of simulated infiltration \& runoff to measured response, utilizing in situ hydraulic conductivities, 4 th rain event 


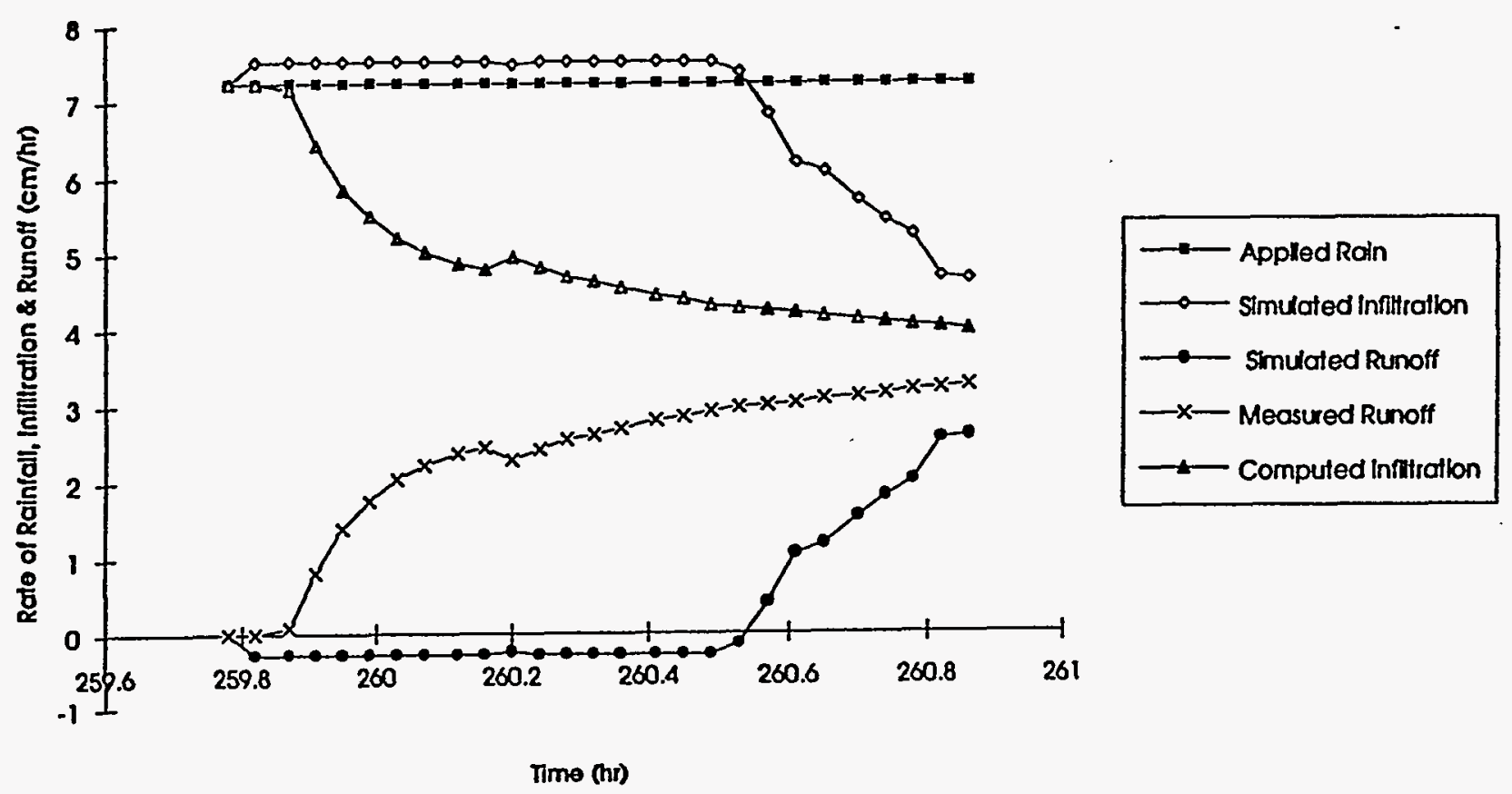

Figure 5.8. Comparison of simulated infiltration \& runoff to measured response, utilizing in situ hydraulic conductivities, 5 th rain event 


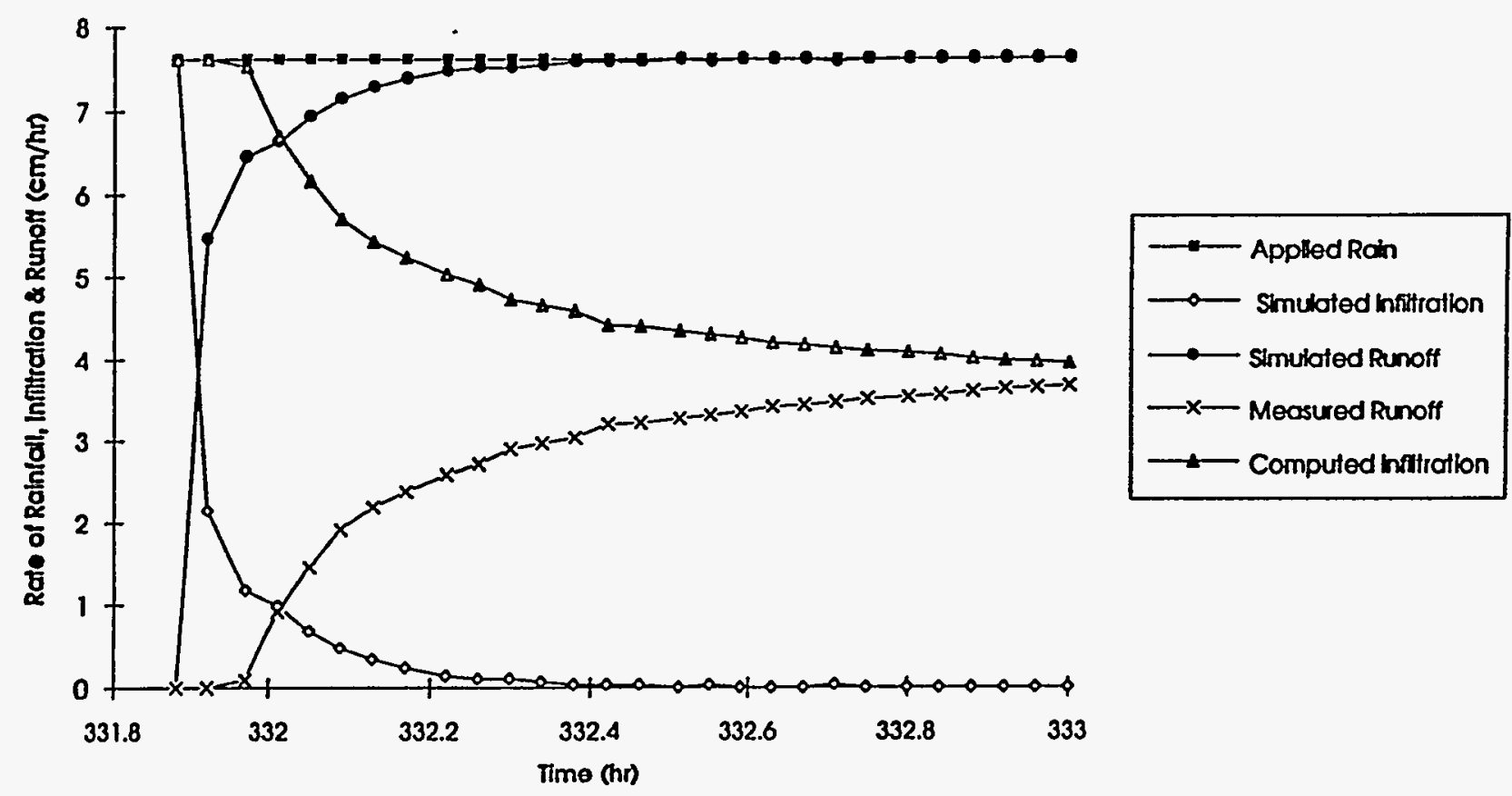

Figure 5.9. Comparison of simulated infiltration \& runoff to measured response, utilizing in situ hydraulic conductivities, 6 th rain event 


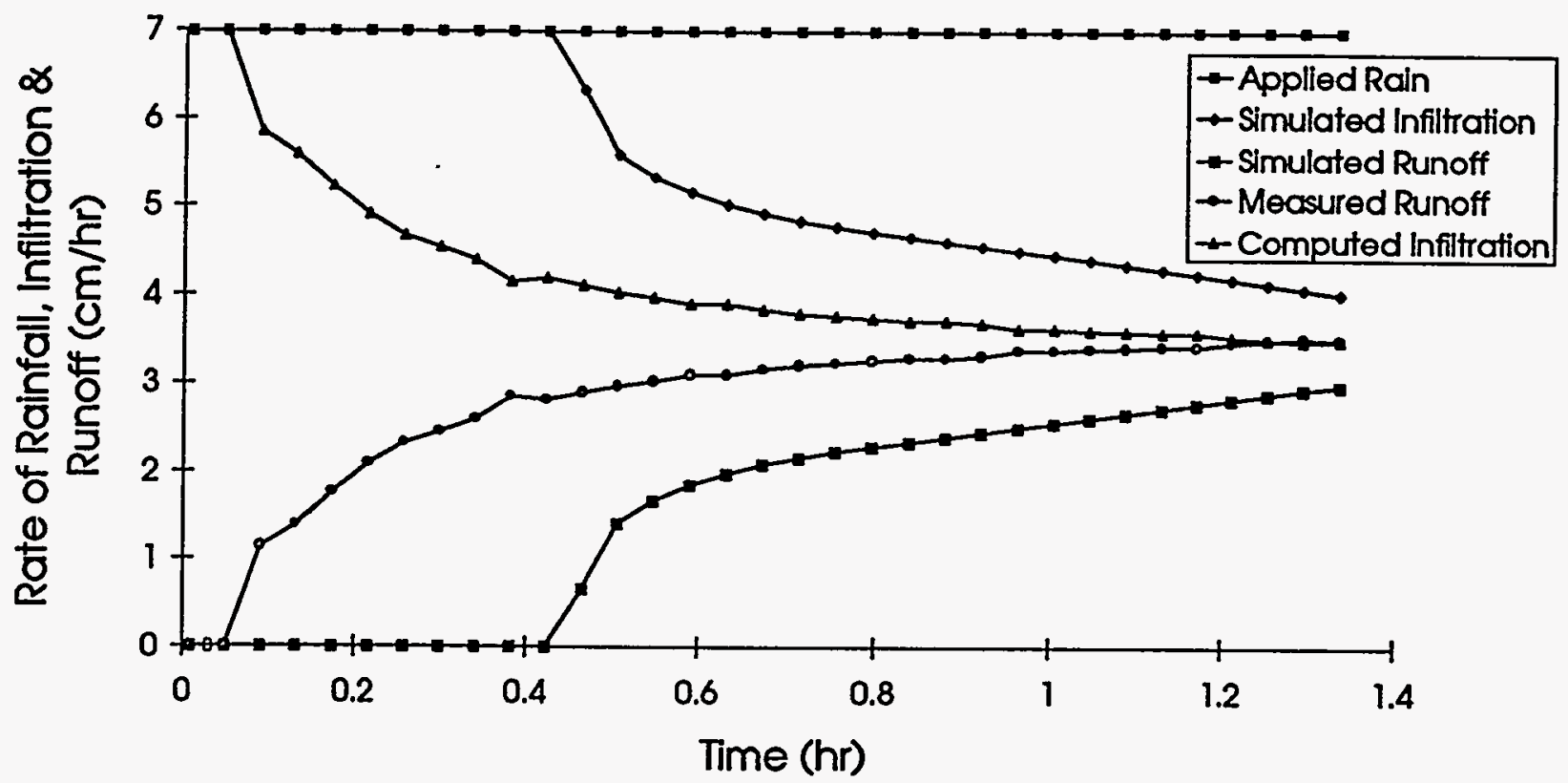

Figure 5.10. Comparison of simulated infiltration \& runoff to measured response, utilizing in situ horizontal hydraulic conductivities and bench-scale vertical hydraulic conductivities, 1st rain event 


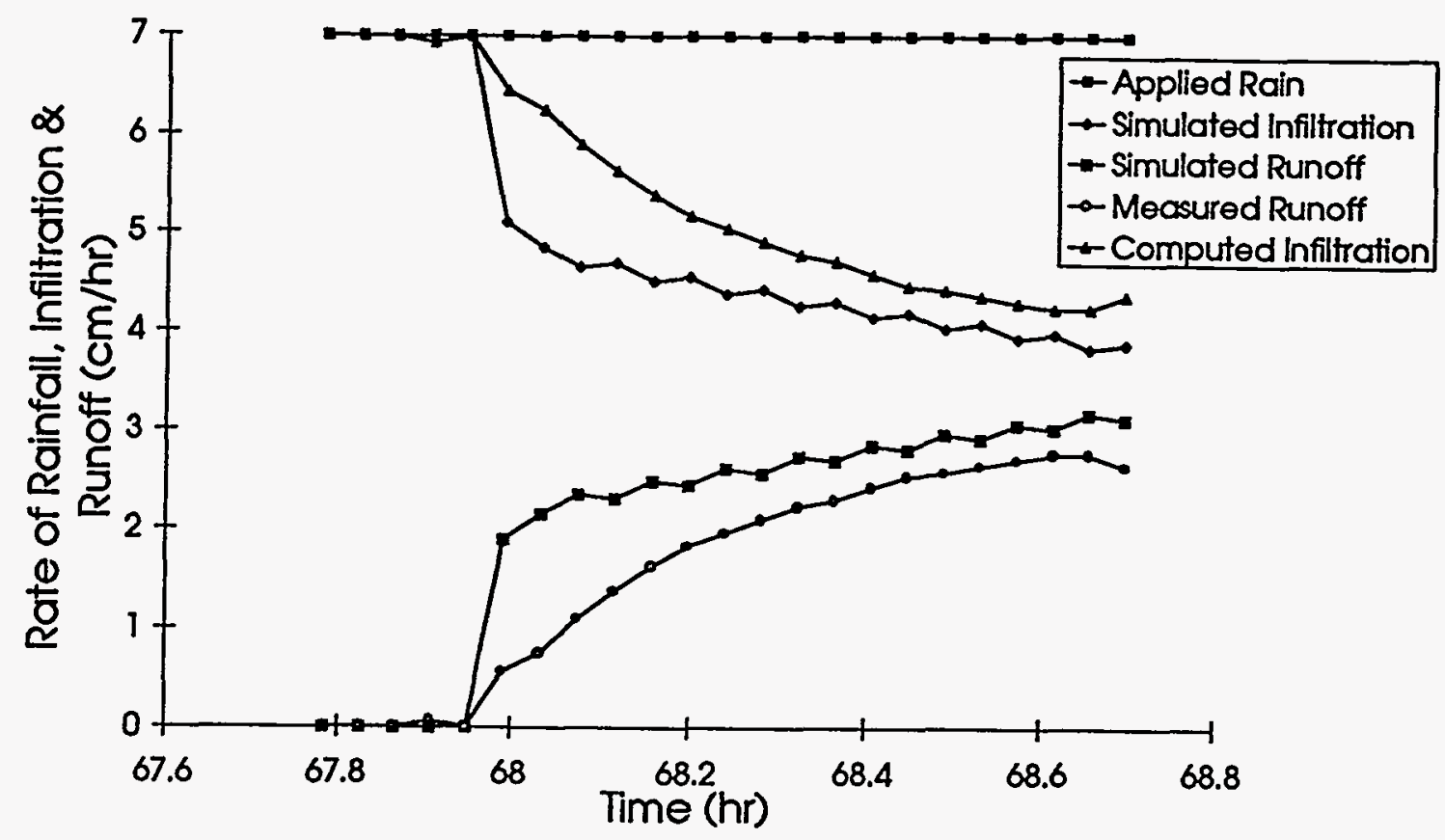

Figure 5.11. Comparison of simulated infiltration \& runoff to measured response, utilizing in situ horizontal hydraulic conductivities and bench-scale vertical hydraulic conductivities, 2nd rain event 


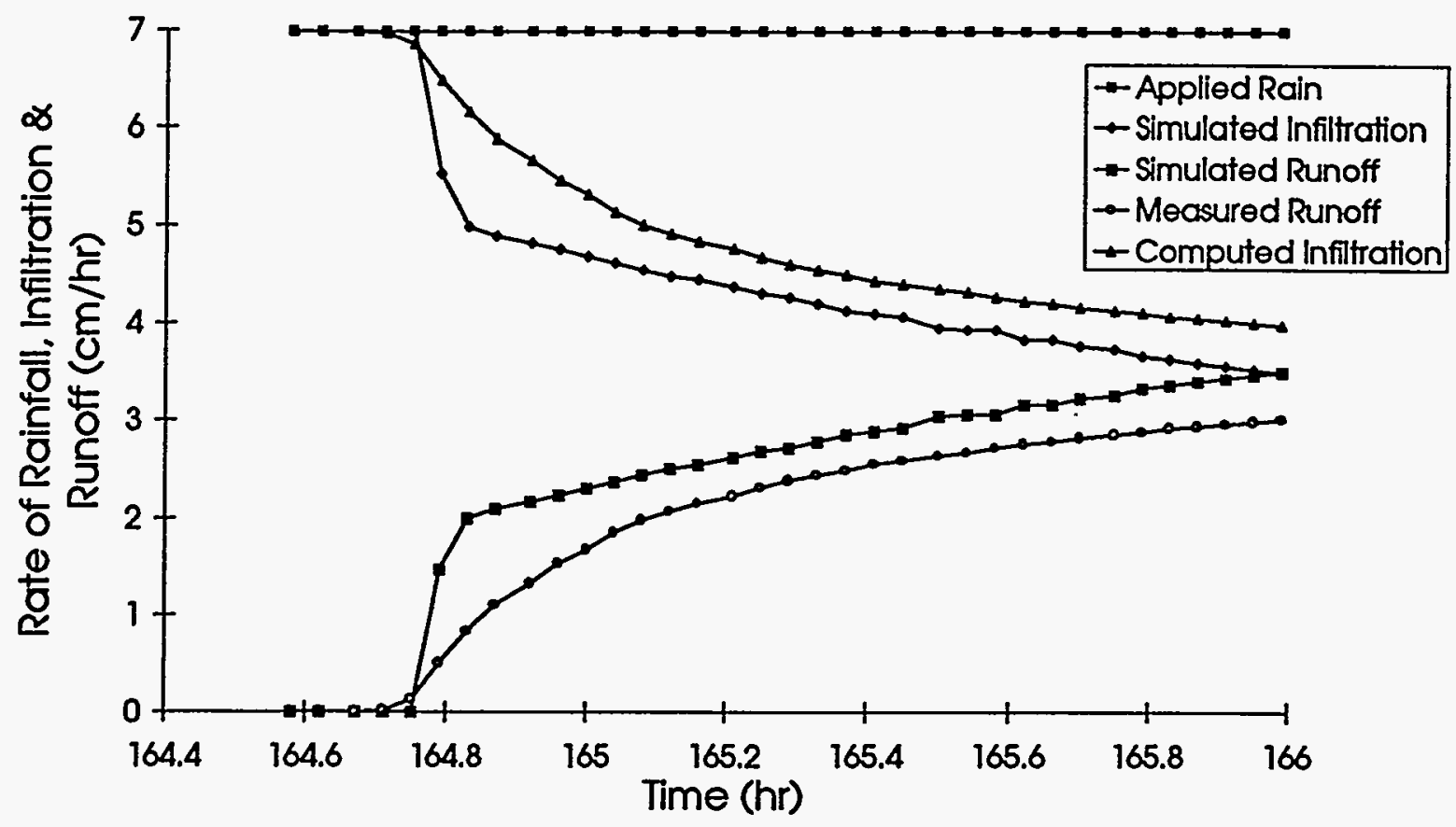

Figure 5.12. Comparison of simulated infiltration \& runoff to measured response, utilizing in situ horizontal hydraulic conductivities and bench-scale vertical hydraulic conductivities, 3rd rain event 


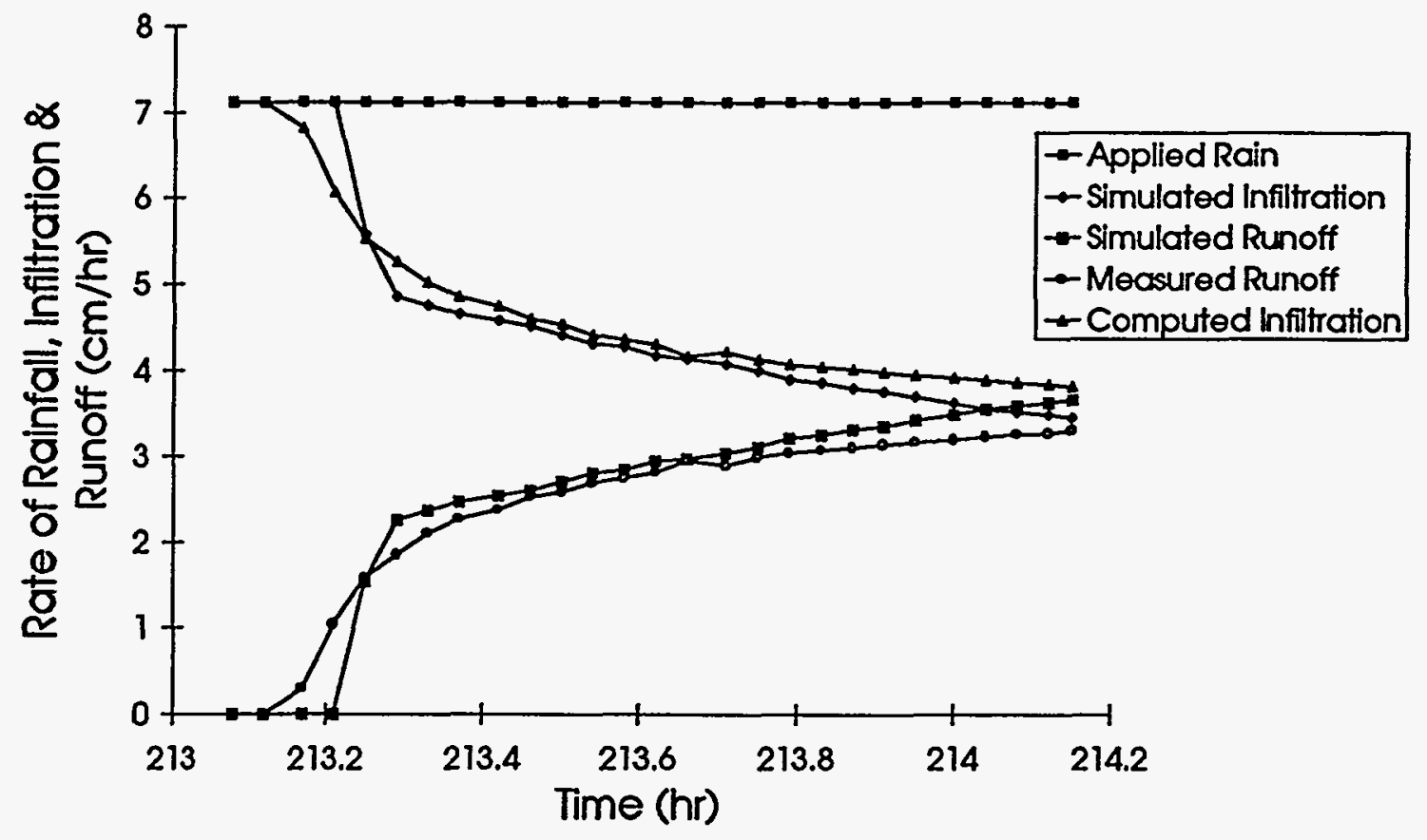

Figure 5.13. Comparison of simulated infiltration \& runoff to measured response, utilizing in situ horizontal hydraulic conductivities and bench-scale vertical hydraulic conductivities, 4th rain event 


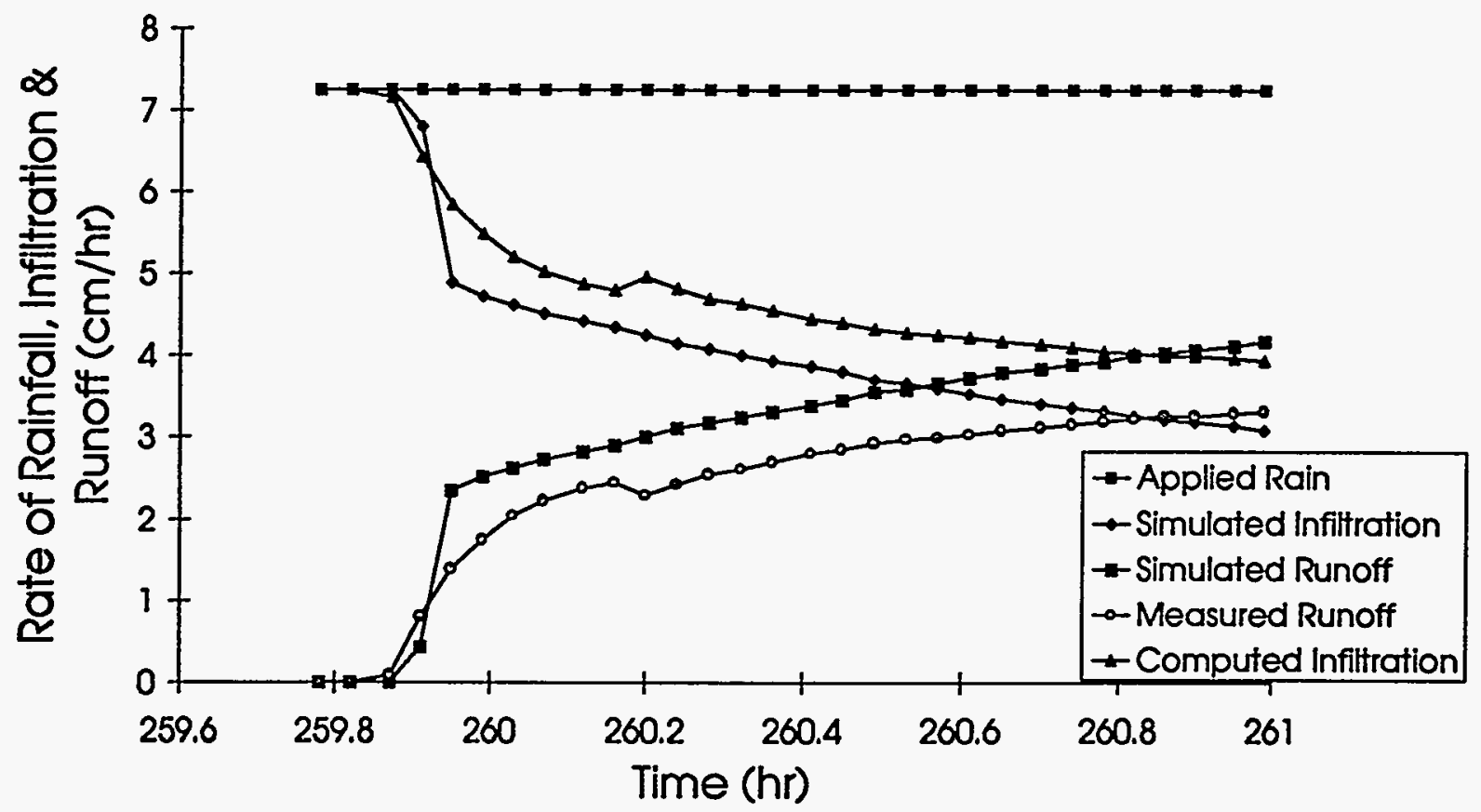

Figure 5.14. Comparison of simulated infiltration \& runoff to measured response, utilizing in situ horizontal hydraulic conductivities and bench-scale vertical hydraulic conductivities, 5th rain event 


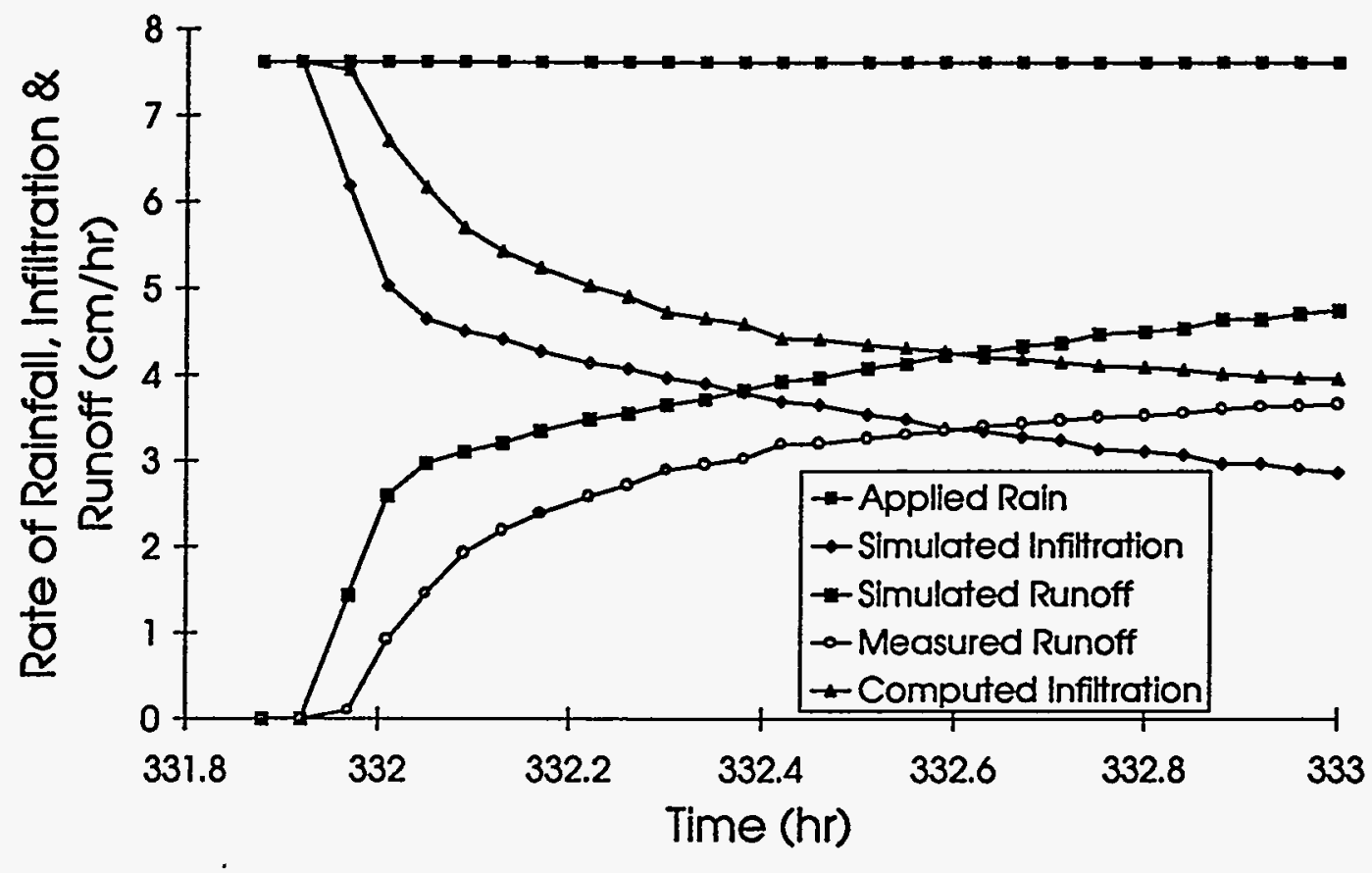

Figure 5.15. Comparison of simulated infiltration \& runoff to measured response, utilizing in situ horizontal hydraulic conductivities and bench-scale vertical hydraulic conductivities, 6th rain event 


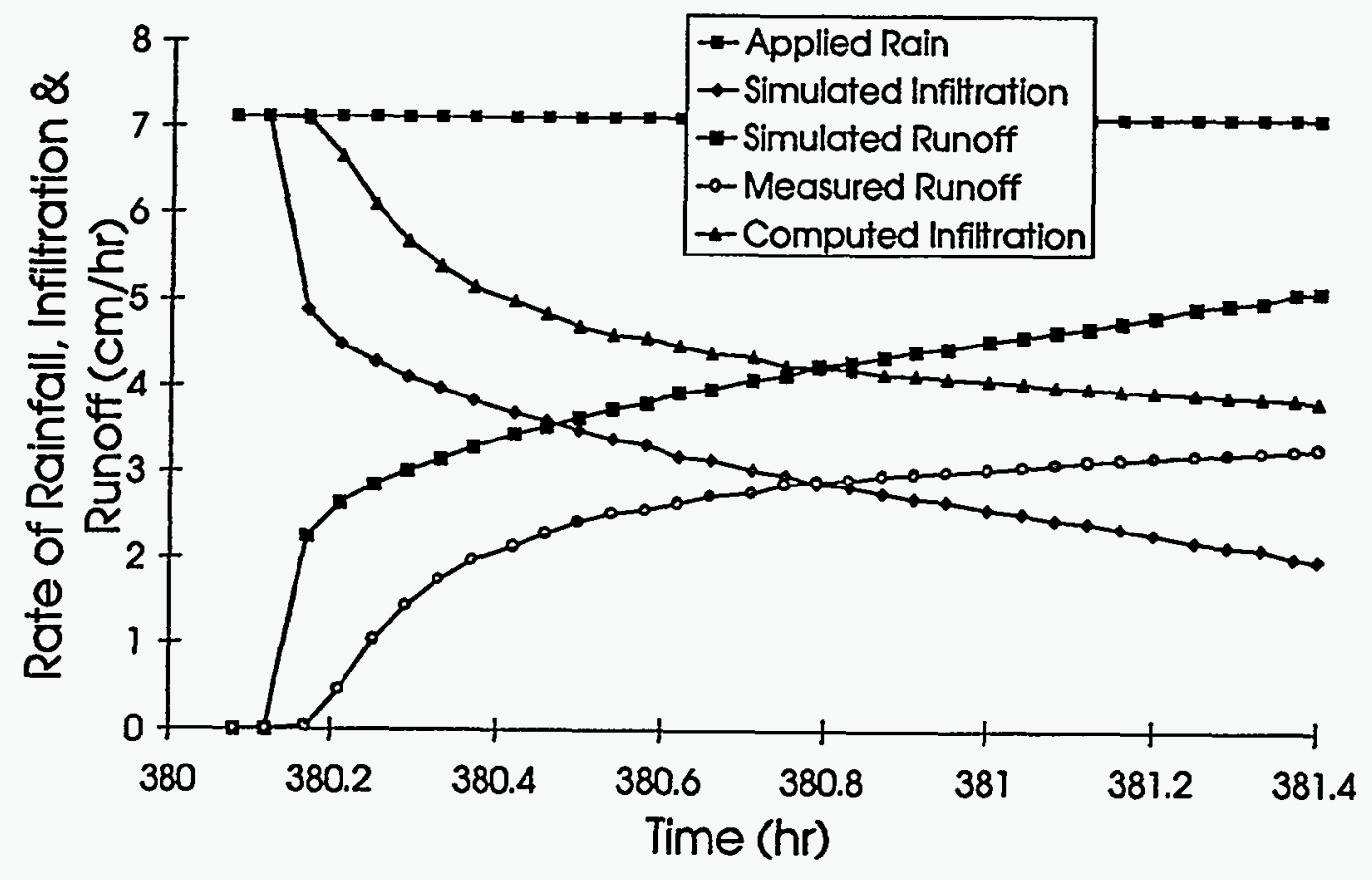

Figure 5.16. Comparison of simulated infiltration \& runoff to measured response, utilizing in situ horizontal hydraulic conductivities and bench-scale vertical hydraulic conductivities, 7 th rain event 


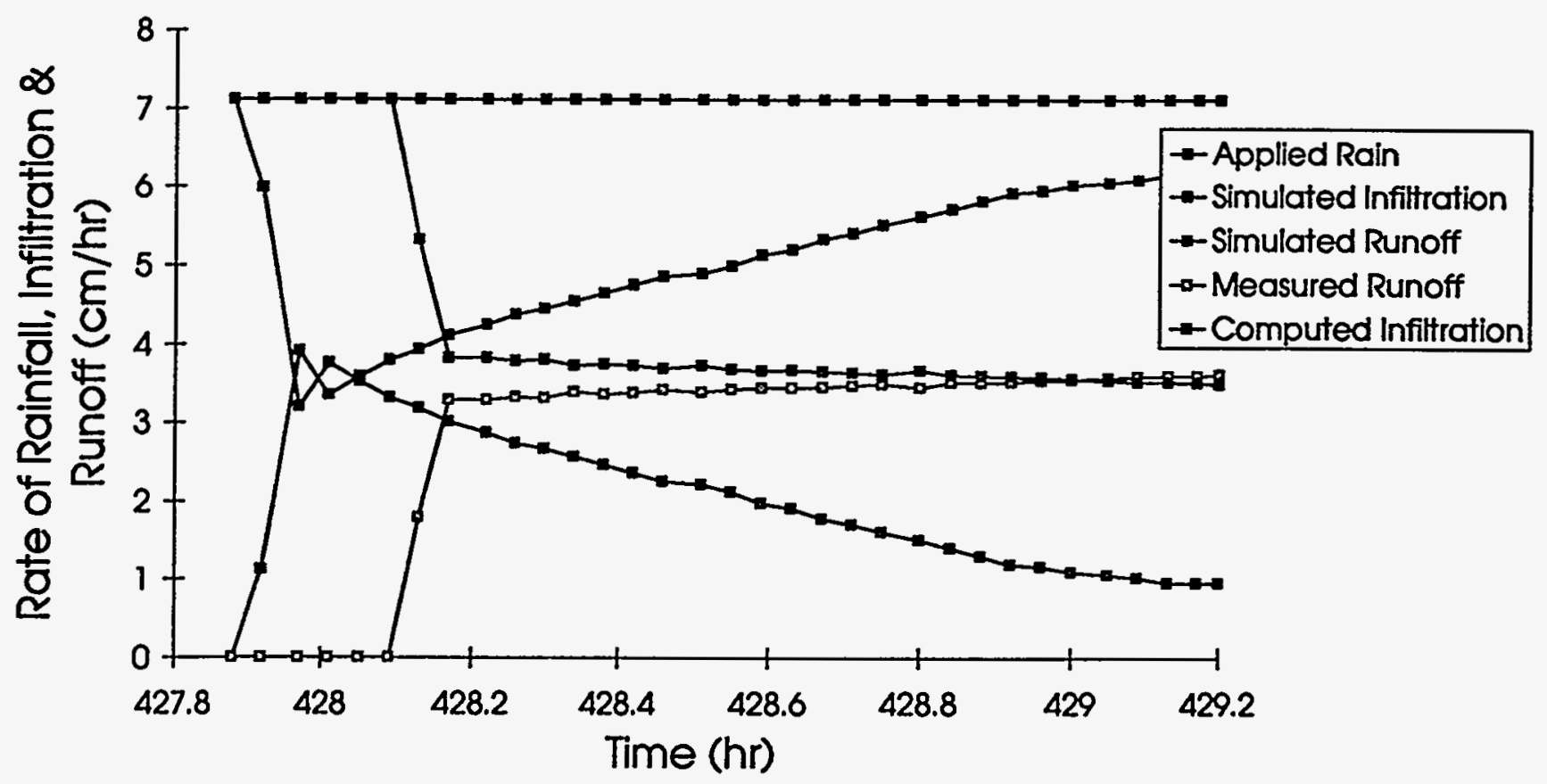

Figure 5.17. Comparison of simulated infiltration \& runoff to measured response, utilizing in situ horizontal hydraulic conductivities and bench-scale vertical hydraulic conductivities, 8th rain event 


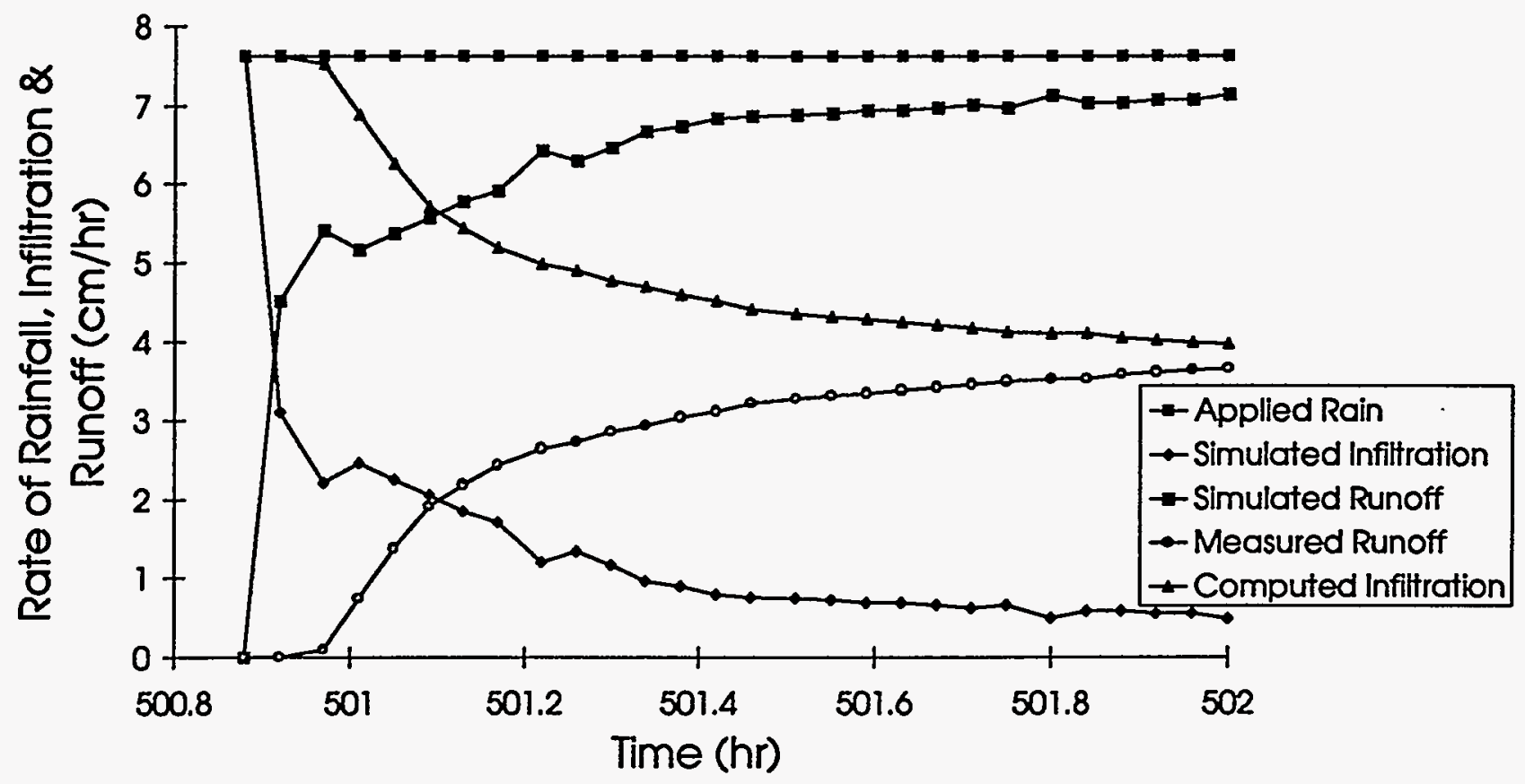

Figure 5.18. Comparison of simulated infiltration \& runoff to measured response, utilizing in situ horizontal hydraulic conductivities and bench-scale vertical hydraulic conductivities, 9th rain event 


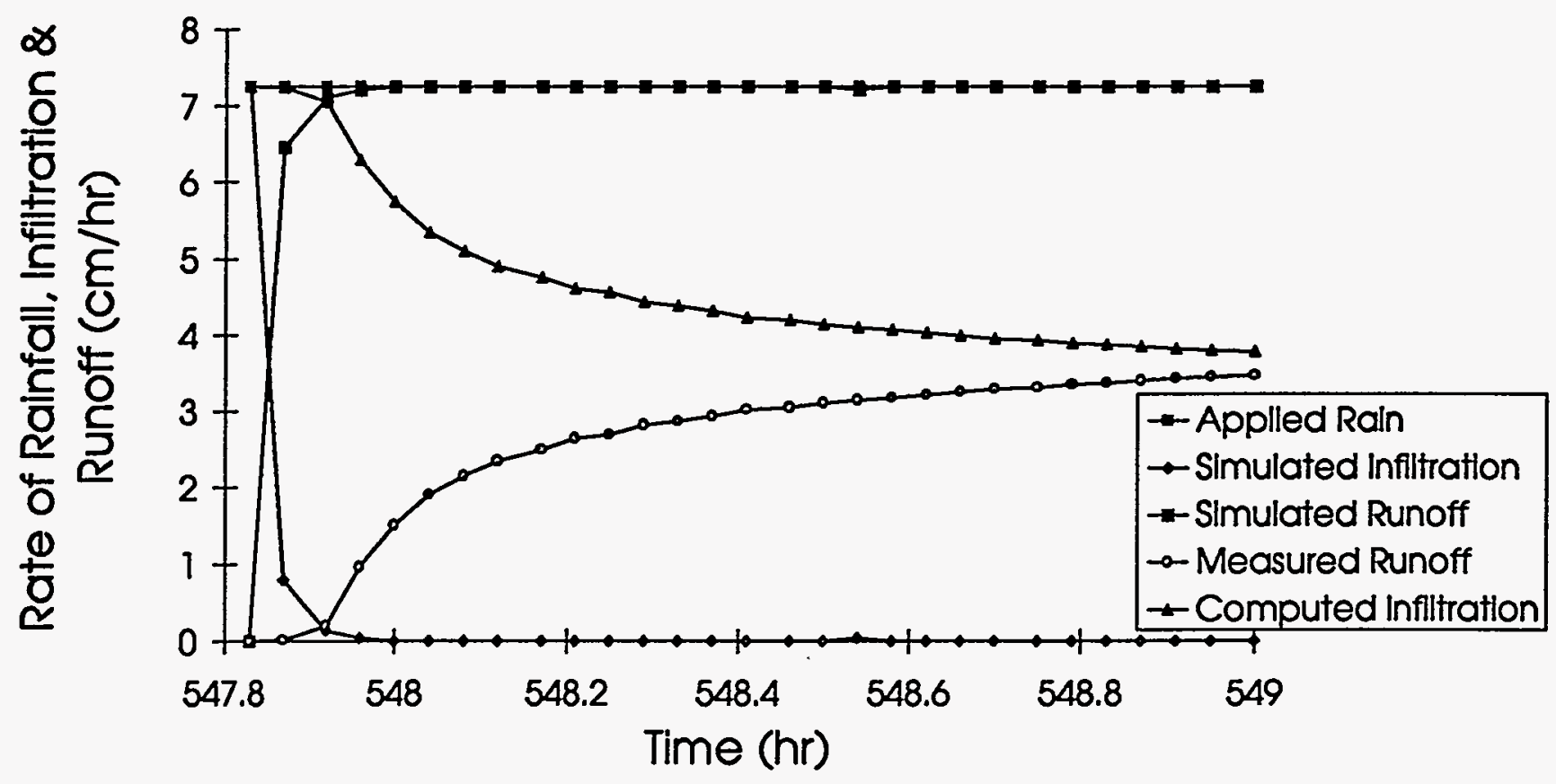

Figure 5.19. Comparison of simulated infiltration \& runoff to measured response, utilizing in situ horizontal hydraulic conductivities and bench-scale vertical hydraulic conductivities, 10th rain event 


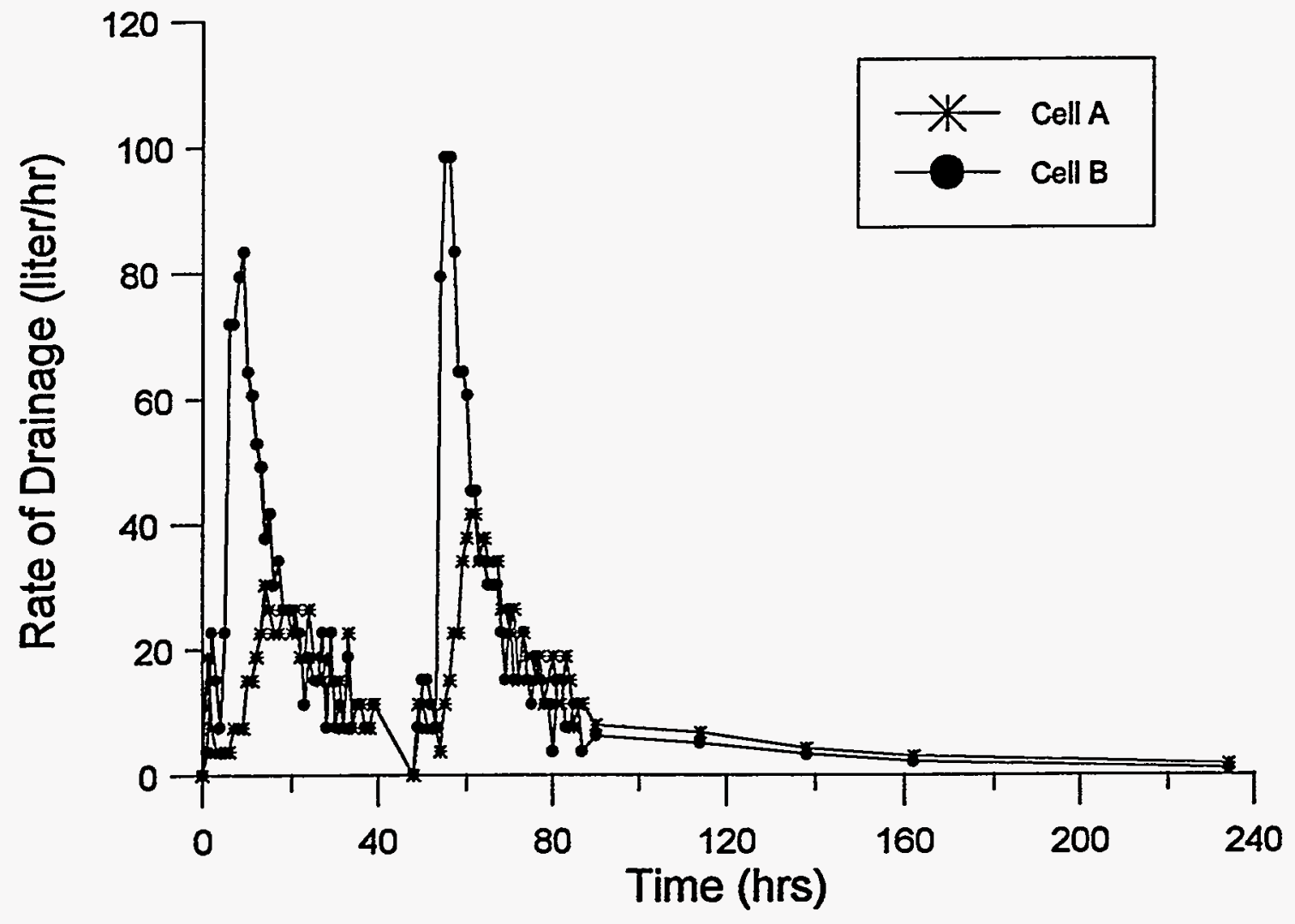

Figure 5.20. Measured drainage from ESL embankments, 21st and 22nd rain events 
content in the spent shale was low, the model could have overestimated the hydraulic conductivity of spent shale initially, and (2) possible overestimation of saturated hydraulic conductivity from double ring infiltrometer tests.

The second set of input data utilized horizontal hydraulic conductivities from Guelph permeameter measurements and vertical hydraulic conductivities from bench-scale test measurements as input. Results shown in Figures 5.10 through 5.19 indicate that numerical modeling can closely predict the infiltration and runoff during the first five rain events. But after five rainstorms, as the cumulative inflow increases, the model starts to overestimate the rate of runoff. This could be due to the fact that the bench-scale specimens undergo uniform cementation unlike large-scale embankments where aggregation could be possible. Hence, the hydraulic conductivity predicted by the bench-scale test would be much lower than the actual hydraulic conductivity measured in the full-scale embankment. It should also be noted that a constant value of porosity and specific storage is assumed in the model. In large scale embankments, however, these values may vary with time and depth. They could vary with change in water content, change in physical and chemical properties, or change in climatic conditions.

Cumulative inflow into the model is computed until the model embankment is saturated and then remains constant. The model reaches a steady state flow condition, at which point all the water applied at the surface runs off with very little infiltration. As the model embankment gets completely saturated, a seepage face develops at the lower boundary. The drainage flux at the saturated nodes slowly increases until the value reaches the rate of applied rainfall. It was observed from the applied rainstorms on the spent shale in the ESL that at the end of the tenth rain, the embankment was completely saturated and started to drain. It was observed from calculation of infiltration and runoff with UNSAT2 that the first simulation model was saturated at the end of the sixth rainstorm and started to drain. However, it was not possible to simulate drainage and movement of water through the embankment beyond the tenth rainstorm. The program was a poor predictor of infiltration, runoff, 
and drainage for this data. The second modeling effort, in which laboratory measured bench-scale data were used, successfully predicted drainage after the tenth rainstorm, but it was not possible to predict the rate of drainage through the embankment. Best predictions were obtained using benchscale values as opposed to measured in situ values. For better predictions of infiltration, runoff, movement of water, and drainage, a parametric analyses needs to be done to determine the effects of different parameters, such as porosity, specific storage, and van Genuchten modeling parameters used in UNSAT2. The results described herein represent a preliminary assessment only and further research on numerical modeling is recommended, including the use of other computer codes in addition to UNSAT2.

\subsection{Summary}

Several commercially-available computer codes are evaluated for their ability to model the hydrogeochemical response of oil shale solid waste embankments. Each code is evaluated for its availability, documentation, ability to account for the pertinent soil properties, computational efficiency, and applicability of the output, in terms of whether the analysis is one-dimensional or twodimensional, and whether the solution is for hydrology only, solute transport only, or both hydrology and solute transport.

The computer program UNSAT2 was used to simulate two-dimensional infiltration, runoff, and drainage from the test embankment in the ESL during twenty-three rain events applied between February and April, 1992. Results of the simulation indicate that it is difficult to model the hydrologic response of the spent shale numerically because of its changing properties with water content and climatic conditions. Simulation indicates that accurate measurement of the soil-moisture retention curve is very important because it plays a significant role in the manner in which the program computes hydraulic conductivity using the van Genuchten modeling parameters. Further research on numerical modeling is recommended. 


\subsection{SUMMARY, CONCLUSIONS, AND RECOMMENDATIONS}

\subsection{Summary}

Oil shale in the Green River Formation represents a significant fossil energy resource to the United States. Although oil shale has not yet (1995) been developed extensively compared to other sources of fossil energy, the potential exists and western oil shale will continue to attract the interest of energy companies whenever economic conditions dictate. For development of western oil shale to take place economically and in a manner that minimizes the risk to human health and the environment, basic information is needed on the feasibility of constructing large oil shale solid waste disposal facilities. The most likely scenario is that spent shale will be disposed of in above-ground waste embankments. The potential for surface water and ground water contamination caused by leachate generated by runoff, infiltration, and seepage of rain and snow falling on waste embankments is a major concern with these large embankments. Stability of such embankments is also a critical aspect of their design and construction and requires reliable information on the strength characteristics of the spent shale. The principal objective of this study was to address the above aspects of oil shale solid waste disposal.

\subsubsection{Review of Previous Work}

A review of the literature indicates that information on the performance of full-size oil shale waste embankments is not available, due mainly to the lack of oil shale development. A number of studies have been conducted on the bench-scale properties of various spent shales. Although each spent shale is different depending upon the process used to convert the raw oil shale to fuel products and the source of the oil shale, there are common characteristics. Most spent shales from the Green River Formation are granular materials with low plasticity, and are classified as either silty gravel (GM), silty sand (SM), or sandy silt (MS). The Lurgi spent shale of this study is a sandy silt 
(MS). In general, soils falling into these categories have favorable strength properties for embankment construction, and moderate to high hydraulic conductivities. This is misleading however, because most of the spent shales exhibit some degree of cementation upon wetting, which can drastically alter their engineering properties depending upon the mixing water content, compaction method, and curing time. This aspect of spent shale behavior is discussed in detail in the sections of this report describing test results.

Several field studies have been conducted on Paraho spent shale to evaluate infiltration and seepage. These tests, involving lysimeters and test ponds, are reviewed in Section 2 and provide valuable data which can be used to predict the amount of leachate likely to be generated in waste embankments of Paraho spent shale or similar materials. The studies were limited to relatively short time periods and may not be representative of long-term conditions. Overall, review of the literature revealed that more research is needed to relate the bench-scale engineering properties of spent shales to full-scale field performance of waste embankments.

\subsubsection{Bench-Scale Testing of Lurgi Spent Shale}

Design of commercial-scale waste embankments of spent shale would most likely be based upon engineering properties estimated from bench-scale tests. One aspect of this study was to conduct a comprehensive bench-scale testing program on the Lurgi spent shale. This was done to evaluate the reliability of properties measured on bench-scale specimens for modeling full-scale performance and to evaluate the significance of cementation on engineering properties.

Strength testing of Lurgi spent shale consisted of consolidated drained (CD) and consolidated undrained (CU) triaxial compression tests, and unconfined compression tests. Drained triaxial tests yield an effective stress friction angle of $\mathbf{3 8}$ degrees and an effective stress cohesion (due to cementation) of $12 \mathrm{kN} / \mathrm{m}^{2}$. Undrained triaxial tests yield a total stress friction angle of 14 degrees and a cohesion of $162 \mathrm{kN} / \mathrm{m}^{2}$. All triaxial specimens were mixed at an initial water content of 15 
percent, similar to the spent shale placed in the field and ESL test embankments, and compacted to an average dry density of $14.0 \mathrm{kN} / \mathrm{m}^{3}$. Unconfined compression tests were designed to evaluate the effects of cementation on the strength of Lurgi spent shale. As shown in Figure 3.7, unconfined compressive strength is affected dramatically by mixing water content and curing time. Specimens mixed at 30 percent water content and cured for 28 days exhibited unconfined compressive strengths of over $8,000 \mathrm{kN} / \mathrm{m}^{2}$, which approaches the strength of weak rock. Lower water contents and shorter curing times result in smaller unconfined compressive strengths.

Hydraulic conductivity of bench-scale specimens also is shown to be affected by mixing water content and cementation. It was found that mixing water content has an important effect on the texture of cured specimens, which in turn affects the pore structure in a way that causes large variations in hydraulic conductivity. At mixing water contents below approximately 25 percent (corresponding approximately to a degree of saturation $=85$ percent), a portion of the mixture consists of relatively large particles (up to $1 \mathrm{~cm}$ in diameter) which are moist on the outside but dry on the inside. Upon curing, these aggregated particles consist of a cemented outer shell, with dry spent shale inside. The resulting texture is similar to a lightly cemented coarse sand or gravel with high permeability. Specimens prepared at higher water contents did not result in large particle aggregations. At the higher water contents, he amount of water is sufficient for the spent shale to be wetted uniformly during mixing, resulting in a moist paste which upon curing forms a dense, uniform, highly cemented matrix with relatively low permeability. The difference in hydraulic conductivity between specimens mixed at different water contents can be several orders of magnitude, as illustrated in Figures 3.9 and 3.12 .

A set of column tests was conducted to determine the quantities of soluble sodium, chloride, sulfate, magnesium, and calcium which occur in leachate from specimens of cured Lurgi spent shale. Results of the leaching tests are presented in Section 3 and can be used to evaluate the environmental impact of spent shale leachate on surface and ground water. 


\subsubsection{Hydrologic Response to Simulated Climatic Conditions}

Large-scale test embankments were constructed at the RBOSC field site, at Tract C-a in western Colorado, and in the Environmental Simulation Laboratory at the University of Wyoming. The field test embankments were used to monitor the hydrologic response to actual climatic conditions during the period 1987-1991, and to verify that similar conditions could be simulated in the ESL. Measurements of precipitation, temperature and relative humidity, and water content as a function of depth were made during this period. These data are recorded in computer files and are available upon request from the project manager at the University of Wyoming. Climatic conditions recorded at the field site over an eighteen month period were reproduced in the ESL between September 1989 and March 1991. Temperature, in situ moisture content profiles, and several climatic variables were monitored during this period and were compared with the profiles measured at the RBOSC field site. The comparison demonstrated that the ESL is able to reproduce conditions closely matching those at the field site.

The test embankments in the ESL were then used to: (1) evaluate in situ hydraulic conductivity and strength properties of the spent shale and (2) evaluate infiltration and seepage under simulated climatic conditions. In situ conductivities were measured using a double-ring infiltrometer and a Guelph permeameter. Measured vertical in situ hydraulic conductivities ranged between $10^{-2} \mathrm{~cm} / \mathrm{s}$ and $10^{-4} \mathrm{~cm} / \mathrm{s}$ (see Figure 4.8 and Table 4.2). Measured conductivities using the Guelph permeameter, which measures primarily horizontal hydraulic conductivity, also ranged approximately between $10^{-2} \mathrm{~cm} / \mathrm{s}$ and $10^{-4} \mathrm{~cm} / \mathrm{s}$. Initially, horizontal conductivities varied over wide ranges, with apparently higher values corresponding to lift boundaries. However, after several years of climatic simulation and several freeze-thaw cycles, horizontal conductivity below a depth of 100 $\mathrm{cm}$ appeared to remain relatively constant at approximately $5 \times 10^{-4} \mathrm{~cm} / \mathrm{s}$. Vertical hydraulic conductivities below $100 \mathrm{~cm}$ appear to converge to values ranging from 2 to $6 \times 10^{-3} \mathrm{~cm} / \mathrm{s}$. These are believed to be the most reliable estimates of long-term in situ hydraulic conductivities for Lurgi 
spent shale, and are one to two orders of magnitude higher than bench-scale hydraulic conductivities. An important result of this study is that bench-scale hydraulic conductivities may not be representative of in situ conditions. The difference is explained in terms of textural differences caused by varying degrees of cementation, as discussed in Section 4.

Careful monitoring of runoff, infiltration, and seepage during twenty three rainfall events during the period between February and May, 1992, produced valuable information on the hydrologic response of Lurgi spent shale under severe climatic conditions. Records of rainfall, measured runoff, and calculated infiltration are presented in Section 5 . Information obtained from these events indicated that an average steady-state infiltration rate of approximately $1 \times 10^{-3} \mathrm{~cm} / \mathrm{s}$ was achieved following the application of several rainfall events. It was observed that after ten rainfall events, over a period of twenty-five days with each rain event lasting about 1.5 hours at a rate of $76 \mathrm{~mm} / \mathrm{hr}$, the embankment with Lurgi spent shale became saturated and began to drain water (leachate) from the test embankment. The embankment with spent shale and raw oil shale overburden mixed became saturated and began to drain following the sixth storm, after a period of 14 days. These observations are consistent with the range of measured in situ hydraulic conductivities and rate of infiltration cited above. These data can be extended to predict the rates and amount of drainage from full-scale waste embankments constructed of Lurgi spent shale or similar materials.

Attempts to obtain undisturbed samples of spent shale from the test embankments for laboratory testing met with mixed success. No samples were obtained from the field embankments, despite several attempts in which a drilling rig was used with core barrels. Attempts to sample the ESL test embankment containing only Lurgi spent shale resulted in retrieval of intact specimens, but only in zones that were highly cemented and that did not exhibit a structure consisting of aggregated particles. Thus, the samples obtained may not have been representative of the embankment as a whole. The samples which were retrieved intact were tested for unconfined compressive strength and hydraulic conductivity. In general, measured strengths were lower than those of bench scale 
specimens, probably due to aggregation of particles during mixing, yielding lower cementation and strength compared to bench-scale specimens which are mixed uniformly with water giving a dense, highly cemented structure. Sample disturbance during drilling may also contribute to lower measured strengths. Measured hydraulic conductivities on core samples were similar to those of bench-scale specimens and lower than measured values from in situ tests. Only a limited number of samples were obtained from zones where the spent shale was highly cemented and similar to bench-scale specimens. It was not possible to obtain samples from most depths in the embankment because the material would fall apart. It is concluded that the measured hydraulic conductivities are most likely not representative of average in situ values.

\subsection{Conclusions}

Disposal of oil shale solid waste requires assessment of the environmental impacts of leachate which may be generated by infiltration and seepage of water through waste embankments. This study shows, based on large-scale testing of model waste embankments, that steady state infiltration rates for Lurgi spent shale or similar materials placed and compacted under conditions described herein, is approximately $1 \times 10^{-3} \mathrm{~cm} / \mathrm{s}$. In situ saturated hydraulic conductivities ranges from $10^{-4}$ to $10^{-2} \mathrm{~cm} / \mathrm{s}$, with an average vertical hydraulic conductivity of $2 \times 10^{-3}$ to $6 \times 10^{-3} \mathrm{~cm} / \mathrm{s}$ and an average horizontal hydraulic conductivity of $5 \times 10^{-4} \mathrm{~cm} / \mathrm{s}$. These values can be used to approximate infiltration and flow in full-scale waste embankments under similar conditions.

Shear strength of Lurgi spent shale is highly dependent upon the degree of cementation, which varies with mixing water content. For estimates of short-term slope stability, unconfined compressive strengths may be used. Figure 3.7 of this report shows the variation of unconfined compressive strength as a function of initial moisture content and curing time. Caution is advised in using this figure for design, however, because unconfined compressive strengths of core samples taken from the test embankment in the ESL exhibited considerably lower unconfined compressive 
strengths, most likely due to significant differences in the texture of the spent shale mixed and placed in the test embankments when compared to bench-scale specimens. Undrained triaxial compression tests indicate a friction angle of 14 degrees with a cohesion of $162 \mathrm{kN} / \mathrm{m}^{2}$. These parameters also are applicable to short-term, undrained stability analysis. The measured cohesion is due primarily to cementation and should be used cautiously, considering the possible differences in cementation between laboratory and field compacted materials.

Drained triaxial tests yield an effective stress friction angle of 38 degrees and an effective stress cohesion (due to cementation) of $12 \mathrm{kN} / \mathrm{m}^{2}$. These values are applicable to long-term stability analyses and are believed to be representative of Lurgi spent shale or similar materials compacted to dry densities reported herein.

\subsection{Recommendations}

The results of this study can be used directly by the U.S. Department of Energy, other government agencies, and companies involved in oil shale development to predict the environmental effects of oil shale solid waste disposal in the Green River Basin. Specifically, it is recommended that predictions of leachate generation made for spent shale disposal facilities be consistent with infiltration and seepage rates observed in the model spent shale test embankments which were ' constructed and monitored in this study. It is further recommended that stability analyses of fullscale disposal embankments consider the results and observations reported herein with regard to the effects of cementation on the strength of Lurgi spent shale. It was found that cementation is the most important factor in determining the strength of Lurgi spent shale and that the process of mixing the spent shale with water and compacting it in large volumes has a profound effect on cementation, the resulting texture, and hydraulic conductivity of the material.

Additional research is recommended on numerical modeling of hydrologic response of oil shale solid waste embankments. This study presents a critical review of available computer codes. 
In addition, the program UNSAT2 was used to model the response of one test embankment in the Environmental Simulation Laboratory. This effort was a first-pass attempt only and did not yield entirely satisfactory results, as described in Section 6 . Further analyses are required to evaluate the sensitivity of the modeled response to soil properties, especially unsaturated hydraulic conductivity. It is further recommended that additional computer programs be used to predict the response of the ESL test embankments to evaluate their capabilities and, if necessary, that new codes be developed specifically for application to oil shale solid waste embankments. 


\section{REFERENCES}

Bloomfield, R.A. and Stewart, B.M. (1981). "Design parameters for oil shale waste disposal system". Bureau of Mines Report of Investigation, RI 8544, U.S. Department of Interior.

Bloomsburg, G.L. and Wells, R.D. (1978). "Seepage through partially saturated shale wastes". Final Report to U.S. Bureau of Mines Under Contract H0252065, Prepared by Ag Engineering Department, University of Idaho, Moscow, Idaho.

Bonazountas, M. and Wagner, J.M. (1981). "SESOIL: A seasonal soil compartment model". Arthur D. Little, Inc. Cambridge, Mass. Prepared for the U.S. Environmental Protection Agency, Office of Toxic Substances, Washington, D.C.

Bond, F.W., Cole, C.R. and Gutkench, P.J. (1982). "Unsaturated groundwater flow model (UNSATID) computer code manual". CS-2434 CCM, Electric Power Research Institute. Palo Alto, California.

Felmy, A.R., Girvin, D., and Jenne, E.A. (1983). "MINTEQ: a computer program for calculating aqueous geochemical equilibria". U.S. Environmental Protection Agency. Washington, D.C.

Gates, T.E. (1982). "Geotechnical properties of PARAHO spent shale." U.S. Department of Energy Contract AC06-6RL01830, NTIS, PC A03/MF A01. PNL-4357, Pacific Northwest Laboratory, Richland, Washington.

Heistand, R.N. (1981). "Retorted oil shale disposal research." Oil Shale, Tar Sand, and Related Materials. American Chemical Society Symposium Series 163: 183-194.

Heistand, R.N. and Holtz, W.G. (1980). "Retorted shale research." Proceedings, Thirteenth Oil Shale Symposium, Colorado School of Mines, Golden, Colorado, 246-254.

Holtz, W.G. (1983). "Compaction and related properties of retorted oil shale." Joumal of Geotechnical Engineering, ASCE, 109(10), 1246-1258.

Huyakorn, P.S. ( 1986). "A three dimensional finite element model for simulating water flow in variably saturated porous media". Water Resources Research, 22(13), 1790-1809.

Lambe, T.W. and Whitman, R.V. (1969). Soil Mechanics, John Wiley and Sons, New York, NY.

Marcus, D., Sangrey, D.A., Miller, S. A. (1985). "Effects of Cementation Process on Spent Shale Stabilization." Transactions of the Society of Mining Engineering, AIME, Vol. 278, 1225-1232.

McWhorter, D.B. (1987). "Retardation of flow in oil shale residues affected by in-situ hydration". Proceedings, Eastern Oil Shale Symposium, Lexington, Kentucky.

McWhorter, D.B. and Brown, G.O. (1985). "Adsorption and flow of water in nearly dry lurgi retorted oil shale." Department of Agricultural \& Chemical Engineering, Colorado State University, Report Prepared for Standard Oil Co. (Indiana) and EPA. 94 p. 
McWhorter, D.B. and Durnford, D.S. (1987). "Leaching and hydraulic properties of retorted oil shale including effects from co-disposal of waste water." Project Summary, EPA600/S7-86/035.

McWhorter, D.B. and Nazarath, V.A. (1984). "Leaching and selected hydraulic properties of procesed oil shales." Environmental Research Brief, EPA 600/D-84-22B.

Morrey, J.R. (1981). "EQUILIB: a computer program to predict complex aqueous equilibria between $0^{\circ} \mathrm{C}$ and $300^{\circ} \mathrm{C}$. Computers in Chemistry Symposium, National A.C.S. Meeting, Atlanta, Georgia.

Narasimhan, T.N. and Witherspoon, P.H. (1977). "Numerical model for saturated-unsaturated flow in deformable media". Water Resources Research, 13(1x03), 657-664.

Nelson. (1982). "TRUST: a computer program for variably saturated flow in multidimensional deformable media". NUREG/CR-2360 PNL-3975, Pacific Northwest Laboratory. Richland, Washington.

Prien, C.H. (1980). "Oil shale resources". in Bates, E.R. and Thoem, T.L. eds., Environmental perspectives on the emerging oil shale industry, Report EPA-600/2-80-205a, U.S. Environmental Protection Agency, Cincinnati, Ohio, 2-11.

Ranjan, R.S. (1989). "Water movement In Lurgi-combusted oil shale affected by time-dependent hydraulic properties." Ph.D. thesis, Colorado State University, Fort Collins, Colorado.

Ranjan, R.S., McWhorter, D.B., Watson, G.H. (1989). "Hydraulic properties of combusted oil shale affected by cementatious reactions." Unpublished report.

Reeves, M. and Duguid, J.O. (1975). "Water movement through saturated-unsaturated porous media: A finite element Galerkin model". ORNL-4927, Oak Ridge National Laboratory, Oak Ridge Tennessee, $232 \mathrm{p}$.

Reeves, T.L., Sullivan, P.J., Gilbert, P.A., Essington, M.E., McQuisten, R., Skinner, Q.D., Hale, G.P. (1986). "Research needs for the surface disposal of processed oil shale solid waste: physical, hydrological, and geotechnical parameters." DOE/MET-86/6071, U.S. Department of Energy.

Rothwell, R.A. (1989). "Initial geotechnical properties of a retorted and combusted oil shale solid waste." M.S. thesis, University of Wyoming, Laramie, Wyoming.

Segol, G. (1976). "A three dimensional Galerkin finite element model for the analysis of contaminant transport in variably saturated porous media". Department of Earth Sciences, University of Waterloo, Canada.

Snethen, D. R., Farrell, W. J., Townsend, F. D. (1978). "A Review Of The Physical And Engineering Properties Of Raw And Retorted Oil Shales From The Green River Formation." Paper S-78-3, U.S. Waterways Experiment Station, Vicksburg, Miss.

Townsend, F.C. and Peterson, R.W. (1979). "Geotechnical properties of oil shale retorted by the PARAHO and TOSCO processes." TR-GL-79-22, U.S. Army Engineer Waterways Experiment Station, Vicksburg, Mississippi. 
Topp, G., and Davis, J. (1985). "Time-domain reflectometry (TDR) and its application to irrigation scheduling." Advances in Irrigation Scheduling, Vol 3, edited by D. Hillel, Academic, Orlando, FL.

Tumer, J.P. and Rothwell, R.A. (1991). "Geotechnical properties of combusted western oil shale." Environmental Geology and Water Science, 17(3). 249-257.

Van Genuchten, M.Th., Pinder, G.F., and Sankin, W.F. (1977). "Modeling of leachate and soil interaction in an aquifer". in Banerji, S.K. (ed.), Management of gas and leachate in landfills, EPA-61019-77-026, Office of Research and Development, U.S. Environmental Protection Agency. Cincinnati, Ohio, 95-103.

Wildung, R.E., Bond, F.W., Gee, G.W., and Nelson, J.D. (1981). "Oil shale solid waste disposal: estimation of embankment physical stability and the movement of water solutes." Oil Shale: The Environment Challenges III. Proceedings of an International Symposium, Vail, Colorado. 26 p.

Yeh, G.T. (1983). "FEMWATER1: A finite element model of waste transport through saturated-unsaturated porous media". Oak Ridge National Laboratory, Oak Ridge, Tennessee.

Yeh, G.T. and Ward, D.S.. (1979). "FEMWASTE finite element model of waste transport through saturated-unsaturated porous media". ORNL 5601, Oak Ridge National Laboratory, Oak Ridge, Tennessee. 